Maurício Morais Tonin

\title{
EFICÁCIA EXECUTIVA DAS SENTENÇAS DECLARATÓRIAS
}

\author{
Dissertação de mestrado apresentada à \\ Faculdade de Direito da Universidade de São \\ Paulo. \\ Área de concentração: Direito Processual \\ Orientador: Prof. Associado Antonio Carlos \\ Marcato
}

Faculdade de Direito da Universidade de São Paulo

São Paulo

Janeiro de 2012 
Banca examinadora:

Professor Associado Antonio Carlos Marcato 


\section{AGRADECIMENTOS}

Ao Professor Antonio Carlos Marcato, pela valorosa oportunidade, confiança e orientação na realização deste trabalho.

Ao Professor José Carlos Baptista Puoli, pela supervisão acadêmica na graduação da USP, minha primeira experiência docente.

Ao Professor Carlos Alberto Carmona, que em primeiro lugar despertou meu interesse pelo direito processual civil com suas Aulas na graduação da USP.

À minha família e aos amigos, que estiveram sempre ao meu lado na realização deste sonho.

Aos colegas da Procuradoria Geral do Município de São Paulo, em especial da Secretaria Municipal de Cultura, pelo incentivo. 
Ao meu irmão gêmeo e grande amigo Ricardo, por ter nascido de novo. 


\section{RESUMO}

O presente estudo baseia-se na alteração promovida pela Lei 11.232/2005 no sistema executivo do Código de Processo Civil. Além de prever o processo civil sincrético, acabando com a necessidade de uma nova demanda - processo de execução - após o término do processo de conhecimento, a lei também alterou conceitos e disposições específicas do Código. A previsão que ganha destaque é a do art. 475-N, inciso I, segundo a qual é título executivo judicial a sentença proferida no processo civil que reconheça a existência de obrigação de fazer, não fazer, entregar coisa ou pagar quantia.

Diante disso, pretende-se fazer uma análise da carga executiva da sentença civil, notadamente da atribuição de eficácia executiva às sentenças declaratórias, na medida em que a lei processual não mais passou a definir a sentença condenatória como o título executivo judicial, mas aquela que reconheça a existência da obrigação.

Neste sentido, é feito em primeiro lugar o estudo da tutela jurisdicional estatal, especialmente da tutela jurisdicional, da sentença judicial, sua classificação, efeitos e coisa julgada. Em seguida, é analisada a execução e o cumprimento da sentença. Por fim, é objeto de estudo a sentença passível de execução, a atribuição de eficácia executiva às sentenças declaratórias e as hipóteses de reconhecimento de obrigação em favor do réu, da procedência e improcedência da ação declaratória negativa e das sentenças declaratórias arbitrais e estrangeiras homologadas pelo STJ. 


\begin{abstract}
The present study is based on the changes made by law 11.232 of 2005 in Brazilian procedural law. Besides establishing the one and only lawsuit by eliminating the necessity of a new suit - execution - after finished the legal discussion, the mentioned law also changed concepts and specific statements of the procedural law. The most important is the one of article 475-N, I, which says that the sentence that recognizes the existence of an obligation of doing, not doing, delivering or paying shall be enforceable.
\end{abstract}

Therefore, it is intended to do an analysis of the sentence and its enforcement, specially for declaratory ones, as the law does not enforce only the conviction, but those sentences that acknowledge the existence of the obligation.

Then, it is first studied the jurisdictional issue, sentence, its classification, its effects and stare decisis. After, it is analyzed the execution. Finally, is studied the sentence and its enforcement, the enforcement of declaratory ones and the acknowledge of an obligation in favor of the defendant, the judgment in favor or against the plaintiff in lawsuits to recognize the inexistence of an obligation, and declaratory arbitration and foreign sentences confirmed by STJ. 


\section{EFICÁCIA EXECUTIVA DAS SENTENÇAS DECLARATÓRIAS}

\section{SUMÁRIO:}

INTRODUÇÃO

1. TUTELA JURISDICIONAL ESTATAL 8

1.1 TUTELA JURISDICIONAL 8

1.1.1 A TUTELA JURISDICIONAL COMO RESULTADO EM FAVOR DO VENCEDOR E PERSPECTIVA DO VENCIDO 12

$\begin{array}{lll}\text { 1.1.2 JURISDIÇÃO E TUTELA JURISDICIONAL } & 14\end{array}$

1.1.3 TIPOLOGIA DA TUTELA JURISDICIONAL 16

$\begin{array}{lll}1.2 & \text { SENTENÇA JUDICIAL } & 19\end{array}$

1.2.1 SENTENÇA COMO TÉCNICA PROCESSUAL 19

1.2.2 O CONCEITO DE SENTENÇA 22

1.2.2.1 SENTENÇA DE MÉRITO 25

1.2.3 ESPÉCIES DE TUTELA E DE SENTENÇA: ANÁLISE CRÍTICA 29

1.2.3.1 SENTENÇA DECLARATÓRIA 38

1.2.3.2 SENTENÇA CONSTITUTIVA 44

1.2.3.3 SENTENÇA CONDENATÓRIA 47

1.2.3.4 SENTENÇA EXECUTIVA 53

1.2.3.5 SENTENÇA MANDAMENTAL 55

1.2.4 COISA JULGADA 57

2. EXECUÇÃO E CUMPRIMENTO DA SENTENÇA 65

2.1 A SATISFAÇÃO DO DIREITO 65

$\begin{array}{lll}2.2 & \text { SISTEMA EXECUTIVO }\end{array}$

2.3 DISTINÇÃO ENTRE CUMPRIMENTO DA SENTENÇA E EXECUÇÃO 73

$\begin{array}{lll}2.4 & \text { TÍTULO EXECUTIVO } & 77\end{array}$

2.4.1 TÍTULOS EXECUTIVOS JUDICIAIS $\quad 81$

2.5 OBRIGAÇÃO DE FAZER, NÃO FAZER, ENTREGAR COISA E PAGAR $\begin{array}{ll}\text { QUANTIA } & 88\end{array}$

2.6 EXECUÇÃO PROVISÓRIA 91

2.7 DEFESAS DO EXECUTADO

3. A CARGA EXECUTIVA DA SENTENÇA CIVIL 95

3.1 A SENTENÇA PASSÍVEL DE EXECUÇÃO 95 
3.2 ATRIBUIÇÃO DE EFICÁCIA EXECUTIVA À SENTENÇA DECLARATÓRIA

3.2.1 A JURISPRUDÊNCIA

3.3 RECONHECIMENTO DE OBRIGAÇÃO EM FAVOR DO RÉU

3.4 AÇÃO DECLARATÓRIA NEGATIVA: PROCEDÊNCIA E IMPROCEDÊNCIA

3.5 SENTENÇAS DECLARATÓRIAS ARBITRAL E ESTRANGEIRA 


\section{INTRODUÇÃO}

"A descrença de todos na Justiça é efeito das mazelas de um sistema acomodado no tradicional método introspectivo, que não inclui a crítica do sistema mesmo e dos resultados que ele é capaz de oferecer aos consumidores finais do seu serviço -, ou seja, aos membros da população". 1

A morosidade do Poder Judiciário e a consequiente descrença nele depositada têm, de longa data, refletido negativamente na economia, na sociedade e até mesmo na cultura do brasileiro. Os processos judiciais demoram anos ou até décadas para serem definitivamente julgados, muitas vezes sem uma boa solução a qualquer uma das partes.

Este quadro de preocupante ineficiência, ressaltado por Cândido Rangel Dinamarco no trecho acima, é resultado da forma arcaica com que o direito era ensinado nas escolas, somada à conduta pouco participativa dos juízes no processo. Segundo referido processualista, de todos os nossos fantasmas, o que mais assombra é o tempo - tempoinimigo -, que corrói direitos e contra o qual o juiz deve travar uma guerra sem tréguas. ${ }^{2}$

Diante dessa realidade e visando melhorar a prestação jurisdicional, o Código de Processo Civil (CPC) de 1973 vem sofrendo constantes reformas - ou minirreformas -, para tentar proporcionar aos operadores do Direito condições de assegurar a todos " $a$ razoável duração do processo e os meios que garantam a celeridade de sua tramitação", nos termos do inciso LXXVIII, do artigo $5^{\circ}$ da Constituição Federal, introduzido pela Emenda Constitucional $n^{\circ} 45 / 2004$, conhecida como a emenda da Reforma do Poder Judiciário.

Tais reformas pontuais no CPC ocorreram ante a experiência da morosidade da aprovação nas Casas do Congresso Nacional de nova legislação sobre todo o assunto, como ocorreu com o Código Civil de 2002, que demorou mais de 25 anos para ser finalmente aprovado. Ocorre que de tantas mudanças, o sistema processual começou a ficar

\footnotetext{
${ }^{1}$ DINAMARCO, Cândido Rangel, A Instrumentalidade do Processo, 12a ed., São Paulo: Malheiros, 2005, p. 11.

2 DINAMARCO, Cândido Rangel, Nova Era do Processo Civil, $2^{\mathrm{a}}$ ed., São Paulo: Malheiros, 2007, p. 12. Dinamarco sustenta que ainda não aprendemos como combater tal problema.
} 
um tanto quanto assistemático, restando ao CPC a jocosa menção de "colcha de retalhos" ou "caleidoscópio".

Em razão disso, o Senado Federal, entendendo ser o momento de reformas mais profundas no direito processual civil, constituiu no ano de 2009 uma comissão de juristas para elaborar um Anteprojeto de Novo Código de Processo Civil ${ }^{3}$. O conjunto de alterações até então realizadas no CPC e mais tantas outras propostas de reformas foram objeto de estudo e debate, o que resultou no Anteprojeto entregue ao Presidente do Senado Federal José Sarney em junho de 2010. ${ }^{4}$

Ressalte-se, contudo, que houve duras críticas à condução dos trabalhos até a redação final do projeto, pois apesar das audiências públicas, jamais se disponibilizou uma minuta do texto para análise. Além disso, muitos processualistas respeitados não participaram da discussão e elaboração do texto. ${ }^{5}$ A despeito disso, o Substitutivo do Projeto de Lei $n^{\circ}$ 166/2010 foi aprovado no Senado Federal no início do mês de dezembro de 2010 e foi encaminhado para a Câmara dos Deputados, recebendo o n ${ }^{\text {o } 8.046 / 2010 .}{ }^{6}$

Enquanto o novo código não é aprovado no Congresso Nacional e encaminhado para sanção presidencial, nota-se que uma das reformas importantes no Código de 1973 que está mantida no projeto de lei do novo código - foi a operada pela Lei Federal $\mathrm{n}^{\circ}$ 11.232 de 22 de dezembro de $2005^{7}$. A proposta originária do anteprojeto foi do Instituto

\footnotetext{
${ }^{3}$ A comissão foi instituída pelo Ato 379 de 2009, do Presidente do Senado Federal, composta por Luiz Fux (Presidente), Tereza Arruda Alvim Wambier (Relatora), Adroaldo Furtado Fabrício, Benedito Cerezzo Pereira Filho, Bruno Dantas, Elpídio Donizetti Nunes, Humberto Theodoro Junior, Jansen Fialho de Almeida, José Miguel Garcia Medina, José Roberto dos Santos Bedaque, Marcus Vinicius Furtado Coelho e Paulo Cesar Pinheiro Carneiro.

${ }^{4} \mathrm{O}$ trabalho da comissão visou atender aos anseios sociais de que a legislação processual privilegie a simplicidade da linguagem e da ação processual, a celeridade do processo e a efetividade do resultado da ação, além do estímulo à inovação e à modernização de procedimentos, respeitando-se o devido processo legal.

${ }^{5} \mathrm{O}$ advogado Sérgio Bermudes, por exemplo, critica a ausência de participação de José Carlos Barbosa Moreira (Código de Processo Civil: mudança inútil. Artigo publicado no Jornal O Globo de 21/12/2010).

6 A íntegra do Código aprovado no Senado Federal pode ser consultada em $<\mathrm{http} / / / \mathrm{www} \cdot$ senado.gov.br/atividade/materia/getPDF.asp?t=84495\&tp=1> acesso em 6/07/2011. O acompanhamento da tramitação do projeto de lei na Câmara dos Deputados é possível em <http://www.camara.gov.br/proposicoesWeb/fichadetramitacao?idProposicao=490267>.

${ }^{7}$ A íntegra da lei pode ser obtida em <http://www.planalto.gov.br/ccivil_03/_ato2004-

2006/2005/lei//11232.htm> acesso em 14/11/2011
} 
Brasileiro de Direito Processual - IBDP e a exposição de motivos do projeto de lei foi do então Ministro da Justiça, Márcio Thomaz Bastos. ${ }^{8}$

Referida lei, que teve um período de vacatio legis de seis meses após a data de sua publicação ${ }^{9}$, aboliu o processo de execução de título executivo judicial, rompendo definitivamente com o binômio processo de conhecimento - processo de execução, de influência liebmaniana. A partir de então, passou a existir um processo civil sincrético, no qual a sentença é executada nos mesmos autos, numa fase executiva, regulada por um capítulo denominado 'Do Cumprimento da Sentença' para as obrigações de pagar quantia, e não mais conforme o combalido Livro II do Código. ${ }^{10}$

Ressalte-se, a esse respeito, que o primeiro passo para tanto foi dado com a Lei Federal no 8.952 de 13 de dezembro de 1994, que alterou o artigo 461 do Código de Processo Civil, determinando que a efetivação da tutela das obrigações de fazer e não fazer se dê no próprio processo de conhecimento onde houver a condenação. Posteriormente, a Lei Federal no 10.444 de 7 de maio de 2002 estendeu essa aplicação às obrigações de entrega de coisa com a inclusão do artigo 461-A ao Código.

Para compatibilizar as novas regras da execução com o sistema processual, o legislador teve de fazer algumas alterações conceituais, que também vieram na Lei 11.232/05. A sentença deixou de ser o ato pelo qual o juiz põe fim ao processo, passando a ser o ato do juiz que implica alguma das situações previstas nos artigos 267 e 269 do Código (art. 162, § $1^{\circ}$ ). Além disso, a expressão que afirmava que publicada a sentença de mérito o juiz cumpria e acabava o ofício jurisdicional foi suprimida do artigo 463, na

\footnotetext{
${ }^{8} \mathrm{O}$ resumo da tramitação do projeto de lei e a exposição de motivos está em <www.bmfbovespa.com.br/pdf/Entrevista210907_04.pdf> acesso em 6/1/2012.

${ }^{9}$ E passou a vigorar, portanto, em 24/6/2006, conforme THEODORO JR, Humberto, As vias de execução do Código de Processo Civil brasileiro reformado. In WAMBIER, Teresa Arruda Alvim (coord). Aspectos polêmicos da nova execução 3: de títulos judiciais, Lei 11.232/2005, São Paulo: Revista dos Tribunais, 2006, p. 311. Idem, nota 2 ao art. 475-N em Código de processo civil comentado e legislação extravagante, Nelson Nery Junior e Rosa Maria de Andrade Nery, 11 a ed., São Paulo: RT, 2010, p. 779.

10 A Lei recebeu críticas de parte da doutrina especializada, sob o argumento de que não resolve os problemas da morosidade da Justiça e altera de forma equivocada a sistemática processual da execução. Araken de Assis, por exemplo, afirma: "Não há lugar para ilusões. O novo sistema não assegura, automaticamente, o êxito na atividade executiva. Ou alguém acredita que, por força dos arts. 475-I a 475-R, os condenados formarão longas filas nas portas dos tribunais, almejando pagar? (ASSIS, Araken de. Sentença condenatória como título executivo. In WAMBIER, Teresa Arruda Alvim (coord). Aspectos polêmicos da nova execução 3: de títulos judiciais, Lei 11.232/2005, São Paulo: Revista dos Tribunais, 2006, p. 20).
} 
medida em que ainda haverá atividade jurisdicional na fase executiva do processo cumprimento da sentença. ${ }^{11}$

Porém, o que merece maior destaque da Lei $\mathrm{n}^{\circ} 11.232 / 2005$ no presente estudo é a previsão acerca da carga executiva da sentença civil. O artigo 475-N passou a atribuir, no seu inciso I, eficácia de título executivo à sentença que reconheça a existência de obrigação de fazer, não fazer, entregar coisa ou pagar quantia. Com isso, abriu-se espaço para relevante discussão doutrinária e jurisprudencial: se a sentença declaratória proferida nestes termos é o bastante para conferir título executivo judicial ao beneficiário desta declaração, já que não foi feita referência específica à sentença civil condenatória, como fazia o art. 584, inciso I do Código, revogado pela lei.

Isto pôs em xeque a tradicional diferenciação da sentença condenatória em relação à declaratória, como título executivo judicial. A sentença não precisaria mais ser necessariamente condenatória para dar ensejo à execução, bastando que reconheça a existência da obrigação.

Frise-se, a esse respeito, que não está em discussão se a lei passou a atribuir eficácia executiva a toda e qualquer sentença declaratória, mas somente àquelas que reconheçam a existência de obrigação de fazer, não fazer, entregar coisa e pagar quantia.

A esse respeito, é importante mencionar que, antes mesmo da lei 11.232/05, o processualista e ministro do Superior Tribunal de Justiça Teori Albino Zavascki já sustentava em trabalhos acadêmicos e também nos seus julgados a tese de que as sentenças declaratórias possuem eficácia executiva. Há decisões de 2004 de sua relatoria que sustentam que o art. $4^{\circ}$, parágrafo único, do $\mathrm{CPC}^{12}$ modificou o padrão clássico da tutela puramente declaratória, que a tinha como tipicamente preventiva, dando ensejo a que a sentença declaratória possa fazer juízo completo a respeito da existência e do modo de ser

\footnotetext{
${ }^{11}$ Assim, buscou-se definir sentença pelo conteúdo do ato judicial - no qual o juiz extingue o processo sem resolução do mérito ou julga o mérito, podendo ou não extinguir o processo -, em detrimento do critério topológico até então adotado. Era imprecisa a definição de sentença como ato que põe termo ao processo, pois com a interposição do recurso de apelação há o prosseguimento do feito, ou mesmo no mínimo haverá execução do capítulo acessório da sucumbência a favor do réu vencedor.

${ }^{12} \mathrm{O}$ dispositivo prevê que é admissível a ação declaratória, ainda que tenha ocorrido a violação do direito.
} 
da relação jurídica concreta. Tais julgados afirmam, ainda, que a sentença declaratória que traz definição integral da norma jurídica individualizada tem eficácia executiva. ${ }^{13}$

Ressalte-se que o projeto de lei do novo Código de Processo Civil, aprovado no Senado Federal em dezembro de 2010 e em tramitação na Câmara, traz previsão semelhante à do atual art. 475-N, inc. I, no art. 502, inc. I. O artigo dispõe que além da sentença condenatória, serão também objeto de cumprimento, de acordo com os artigos previstos no Título do Cumprimento da Sentença do Código, as sentenças proferidas no processo civil que reconheçam a exigibilidade de obrigação de pagar quantia, de fazer, de não fazer ou de entregar coisa.

O legislador, de lege ferenda, pretende incluir na redação do dispositivo que a sentença para ser título executivo, além de reconhecer a existência, deverá reconhecer a exigibilidade da obrigação, não alterando, porém, com isso, o sentido da previsão do art. 475-N, inc. I, do CPC. Na realidade, a redação deixa expresso que não só a sentença condenatória é título executivo judicial, o que acabaria com a celeuma. Além disso, o art. 19, parágrafo único do mesmo projeto de lei dispõe que é admissível a ação declaratória ainda que tenha ocorrido a violação do direito, previsão idêntica à do art. $4^{\circ}$, parágrafo único do CPC em vigor. Isto demonstra que a importância do estudo permanecerá, mesmo após a aprovação do novo Código, se e quando ocorrer. ${ }^{14}$

E várias são as questões que gravitam em torno dessa previsão legal, possivelmente alterando soluções de casos concretos que são diariamente julgados pelo Poder Judiciário e submetidos às regras do direito processual civil.

Inicialmente, será analisada no Capítulo I a tutela jurisdicional estatal. O estudo da tutela jurisdicional readquiriu importância na obra dos autores mais modernos. A reabilitação do conceito de tutela jurisdicional é contemporâneo à relativização do binômio

\footnotetext{
${ }^{13}$ Citem-se os RESPs 588.202, DJ 10/02/2004, e 614.577, DJ 23/03/2004.

${ }^{14}$ Os trabalhos da Comissão de elaboração do novo Código se orientaram precipuamente por cinco objetivos, conforme denota-se da exposição de motivos do anteprojeto: 1) estabelecer expressa e implicitamente verdadeira sintonia fina com a Constituição Federal; 2) criar condições para que o juiz possa proferir decisão de forma mais rente à realidade fática subjacente à causa; 3) simplificar, resolvendo problemas e reduzindo a complexidade de subsistemas, como, por exemplo, o recursal; 4) dar todo o rendimento possível a cada processo em si mesmo considerado; e, 5) finalmente, sendo talvez este último objetivo parcialmente alcançado pela realização daqueles mencionados antes, imprimir maior grau de organicidade ao sistema, dando-lhe, assim, mais coesão.
} 
direito-processo, bem como ao desdobramento do postulado da instrumentalidade do processo, tendo em vista o fato de partirem em busca de um escopo comum: a análise do sistema processual sob o ângulo dos demandantes. ${ }^{15}$ A tutela jurisdicional está reservada somente aos que efetivamente estejam amparados pelo direito material, devendo ser considerada como a análise do fenômeno processual do ângulo de quem tem razão.

A tutela é garantida através dos atos estatais, sendo o provimento final e mais importante a sentença judicial. Em razão disso, será estudado o conceito de sentença, a classificação quinária e ternária das sentenças, e a superveniente irrelevância prática desta distinção, sob o ponto de vista executivo, diante da nova concepção de título executivo judicial do artigo 475-N, inciso I, que se defenderá. Ainda, analisar-se-á a coisa julgada e seus efeitos.

Em seguida, será objeto de estudo no Capítulo II o mecanismo de satisfação do direito reconhecido no título: a execução e o cumprimento da sentença. Diante das alterações introduzidas no sistema executivo pela lei 11.232/05, somadas ao que já previam os artigos 461 e 461-A, introduzidos no Código em 1994 e 2002, tonando sincrético o processo civil, serão analisados os principais institutos da execução, especialmente em relação ao cumprimento da sentença judicial, em razão do escopo do trabalho.

Por fim, no Capítulo III será analisada a carga executiva da sentença civil, nos termos do artigo 475-N, inciso I do CPC. Inicialmente, será estudada a atribuição de eficácia executiva à sentença declaratória, como visto pela doutrina e pela jurisprudência. Além disso, será objeto de análise a possibilidade de o réu vencedor obter na sentença de improcedência o reconhecimento de direito seu em face do autor - uma das obrigações discriminadas na lei - e, com isso, poder executar o julgado em seu favor.

Da mesma forma, será importante analisar a ação declaratória de inexistência de relação jurídica - declaratória negativa - e os possíveis efeitos na hipótese de improcedência da ação. Por outro lado, relevante será um paralelo com os incisos IV e VI do art. 475-N, que preveem como título executivo judicial a sentença arbitral e a sentença

${ }^{15}$ VASCONCELOS, Ronaldo, Eficácia executiva das sentenças declaratórias no CPC (Lei n. 11.232/05), In COSTA, Suzana Henriques da (coord.), A Nova Execução Civil - Lei 11.232/05, São Paulo: Quartier Latin, 2006, p. 98. 
estrangeira devidamente homologada pelo Superior Tribunal de Justiça, especificamente quando forem declaratórias e reconheçam a existência de obrigação.

Assim, evidentemente sem qualquer pretensão de esgotar o assunto, a eficácia executiva das sentenças declaratórias mostra-se tema de relevância no direito processual, que está presente nos modernos debates acadêmico e jurisprudencial e merece ser objeto de estudo em dissertação de mestrado. 


\section{TUTELA JURISDICIONAL ESTATAL}

\subsection{Tutela jurisdicional}

Na vida cotidiana, indivíduos e grupos de indivíduos envolvem-se em conflitos com outros, relativamente a bens materiais ou situações desejadas ou indesejadas, nem sempre chegando a uma solução negociada. Isso é inerente a uma sociedade com interesses infinitos, que possui recursos finitos. Em alguns casos, são pretensões que encontram resistência da pessoa que poderia satisfazê-las e não as satisfaz, em outros a própria ordem jurídica exclui que sejam satisfeitas por ato do sujeito envolvido. Em ambas as hipóteses, se não houver a resignação do sujeito quanto ao bem da vida que constitui objeto da pretensão, o caminho permitido para tentar a satisfação é o processo, sendo indiferente se a razão está com o irresignado ou com o adversário. ${ }^{16}$

É, portanto, através do processo que a lei permite ao autor buscar perante o Estado a tutela de seu direito invocado, solucionando-se o conflito pelo exercício da jurisdição. Em todos os povos, mas notadamente no Estado de Direito, é natural que o exercício da jurisdição se submeta a um complexo conjunto de regras jurídicas destinadas ao mesmo tempo a assegurar a efetividade dos resultados - tutela jurisdicional -, a permitir a participação dos interessados pelos meios mais racionais e a definir e delimitar a atuação do juízes. ${ }^{17}$

Neste sentido, tutela jurisdicional, de acordo com José Roberto dos Santos Bedaque, corresponde à proteção a ser conferida pelo Estado-jurisdição à situação da vida retratada abstratamente em regras existentes no plano do direito material. Por não ser a lei substancial suficiente para assegurar a satisfação espontânea do interesse por ela própria assegurado, necessário buscar auxílio na função estatal criada exatamente para impor coercitivamente a vontade do legislador. ${ }^{18}$

16 DINAMARCO, Cândido Rangel. Instituições de Direito Processual Civil, vol. I, 5ª Ed., São Paulo: Malheiros, 2005, p. 53/54. Mister citar, além do processo judicial, os meios alternativos de solução controvérsia, como a arbitragem, a conciliação e a mediação, que cada vez mais estão sendo estudados pela comunidade acadêmica e utilizados na solução dos conflitos.

${ }^{17}$ DINAMARCO, Cândido Rangel. Instituições..., vol. I, cit., p. 55.

18 BEDAQUE, José Roberto dos Santos. Efetividade do Processo e Técnica Processual. São Paulo: Malheiros, 2006, p. 507/508. O autor ainda conclui, de modo simplificado, que tutela jurisdicional configura 
A esse respeito, a reabilitação do conceito de tutela jurisdicional é contemporânea à relativização do binômio direito-processo, bem como ao desdobramento do postulado da instrumentalidade do processo, tendo em vista o fato de partirem em busca de um escopo comum: a análise do sistema processual sob o ângulo dos demandantes. Bedaque afirma que um dos aspectos fundamentais para a eliminação do litígio está na maior aproximação entre direito material e processo, posto que as relações entre um e outro são intensas e o perfeito conhecimento do processo depende da correta identificação desse nexo. ${ }^{19}$

A Constituição Federal garante que todos têm o direito de propor demandas, através do princípio da inafastabilidade da jurisdição. Preenchidos os requisitos das condições da ação e dos pressupostos processuais, alcança-se o direito ao provimento jurisdicional no mérito. No entanto, a tutela jurisdicional está reservada somente aos que efetivamente estejam amparados pelo direito material. ${ }^{20}$

Bedaque alerta que o emprego do termo tutela jurisdicional não tem sido feito de maneira uniforme pela doutrina. Para este autor, existem alguns processualistas que conferem à expressão sentido abstrato, isto é, desvinculado do direito material, sendo que, na realidade, tutela jurisdicional é o conjunto de medidas estabelecidas pelo legislador processual a fim de conferir efetividade a uma situação da vida amparada pelo direito substancial. $^{21}$

Após a percepção de que a ação não se confunde com o direito material nela afirmado, o direito de ação foi visto como direito a uma sentença de mérito, favorável ou

a proteção dada pelo Estado-juiz ao direito subjetivo ou transindividual, após demonstrada sua existência no processo (p. 508).

19 BEDAQUE, José Roberto dos Santos. Direito e Processo - influência do direito material sobre o processo. $5^{\text {a }}$ ed, São Paulo: Malheiros, 2009, p. 19. O processualista ainda afirma que a natureza instrumental do direito processual impõe sejam seus institutos concebidos em conformidade com as necessidades do direito substancial. Isto é, a eficácia do sistema processual será medida em função de sua utilidade para o ordenamento jurídico material e para a pacificação social. Sustenta, assim, que não interessa uma ciência processual conceitualmente perfeita, mas que não consiga atingir os resultados a que se propõe. Menos tecnicismo e mais justiça, é o que se pretende (p. 19).

${ }^{20}$ BEDAQUE, José Roberto dos Santos. Direito e Processo..., cit., p. 31.

${ }^{21}$ BEDAQUE, José Roberto dos Santos. Direito e Processo..., cit., p. 39/40. Semelhante é o significado da expressão tutela jurídica de direitos, utilizada pela doutrina italiana, que representa a garantia constitucional de tutela jurisdicional de todos os direitos subjetivos, sendo impossível ao legislador subtrair das pessoas a possibilidade de acesso ao Poder Judiciário. Também se fala em direito processual substancial para indicar as diversas espécies de tutela jurisdicional. Embora estabelecidas no ordenamento material, têm natureza processual. Encontram-se em posição intermediária, entre aquelas normas substanciais que preveem direitos subjetivos e as que disciplinam o modo de atuação da tutela (p. 41). 
desfavorável ao autor. O direito de ação, quando visto no quadro dos direitos fundamentais, não pode ser resumido ao direito de ir a juízo, ao direito de acesso à justiça ou ao direito ao julgamento de mérito. O direito de ação é o direito de utilizar o processo para poder obter a tutela do direito material, desde que, obviamente, o direito seja reconhecido em juízo. 223

Assim, é preciso não esquecer que ter direito fundamental à tutela jurisdicional efetiva é ter direito às técnicas processuais idôneas à obtenção da tutela prometida pelo direito material. Nesse contexto, pelo que sempre se entendeu e está em toda a doutrina nacional e internacional, processo de conhecimento é uma série de atos interligados e coordenados ao objetivo de produzir tutela jurisdicional mediante o julgamento da pretensão exposta ao juiz. Como em todo processo jurisdicional, os atos que o compõem são realizados por sujeitos também interligados entre si por um vínculo muito especial e típico, que é a relação jurídica processual. ${ }^{24}$

De acordo com a doutrina de Cândido Rangel Dinamarco, o mais relevante dos fatores que identificam o processo de conhecimento e o diferenciam das demais espécies de processo é a sentença de mérito, que só ele é apto de produzir. Segundo referido autor, o processo de conhecimento, quando reduzido à sua expressão mais simples, compõe-se do quadrinômio demanda, defesa, cognição e sentença. ${ }^{25}$

O jurista italiano Alfredo Rocco, ao iniciar o estudo da sentença civil, afirma que os conceitos de jurisdição como função e como poder, de processo como atividade, explicada pela função, de direito processual como complexo de normas que tal função, e portanto,

\footnotetext{
${ }^{22}$ MARINONI, Luiz Guilherme; ARENHART, Sérgio Cruz. Curso de processo civil, volume 3: execução. $2^{\mathrm{a}}$ Ed., São Paulo: RT, 2008, p. 58.

${ }^{23}$ Bedaque afirma que o estudo do processo somente pela perspectiva do direito de acesso ao Poder Judiciário não é satisfatório. Questiona de que adianta, para o ordenamento substancial, para a efetiva pacificação, assegurar-se o direito de demandar? Necessário que o consumidor do serviço jurisdicional obtenha a satisfação total de seus interesses legitimamente postulados, pois apenas esse resultado atende à promessa estatal de proteção aos direitos (Direito e processo..., cit., p. 33).

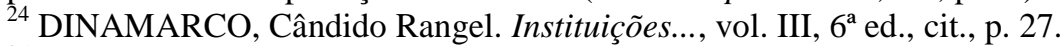

${ }^{25}$ DINAMARCO, Cândido Rangel. Instituições..., vol. III, $6^{a}$ ed., cit., p. 28. Dinamarco, por outro lado, frisa que não pode ser absoluta a distinção entre os processos de conhecimento e execução, pelo critério da existência ou inexistência de cognição, julgamento ou constrições. $\mathrm{O}$ que identifica o processo de conhecimento é, acima de tudo, o julgamento imperativo e definitivo acerca da existência, inexistência ou modo de ser do direito das partes ao bem da vida. Quando às atividades de diversas naturezas, já somente preponderâncias (ob. cit., p. 29).
} 
tais atividades regulam, são os pressupostos indispensáveis do assunto. E isto por dois motivos.

Primeiramente, pela estreitíssima conexão lógica que relaciona os vários elementos do processo, como partes de um todo, endereçados a um único escopo, que de suas posições no complexo definem características e relevância. Depois, pela particular posição da sentença no conjunto do processo, o qual, na fase de conhecimento, encontra na sentença justamente o ato final, ao qual todos os outros atos buscam como meta imediata, e, na fase de execução, se apresenta frequentemente como execução do conhecimento contido na sentença. Constitui o título e determina os limites, de modo que a sentença é sempre o ponto final do processo de conhecimento e, frequentemente, o ponto de partida do processo de execução. ${ }^{26}$

Para referido autor, a característica da atividade jurisdicional está, portanto, em ser uma atividade do Estado, substituída pela atividade daqueles a quem a norma jurídica prescreve, para a tutela de determinados interesses, uma determinada conduta, por esses não observada. Neste sentido, define jurisdição como a atividade com a qual o Estado procura diretamente a satisfação dos interesses tutelados pelo direito, quando por qualquer razão - incerteza ou inobservância - não seja executada a norma jurídica que tutela tal direito. Assim, o escopo da jurisdição, dado este pressuposto, é de procurar a satisfação de tal interesse, assegurando o direito do caso concreto, e intervindo para tanto, mesmo sem ou contra a vontade daquele, frente ao qual a tutela é concedida. ${ }^{27}$

Por outro lado, Bedaque reconhece que o processo não vem cumprindo a sua função. Para o autor o instrumento estatal de solução de controvérsias tem sido muito mais fonte de conflitos que meio pelo qual se obtém a pacificação social. As denominadas questões preliminares, de natureza exclusivamente processual, acabam se transformando no objeto principal do processo, ofuscando a matéria de mérito, que muitas vezes sequer chega a ser examinada. Neste sentido, repensando a técnica processual, referido

\footnotetext{
${ }^{26}$ ROCCO, Alfredo. La Sentenza Civile, Studi, Milano, Giuffrè, 1962, p. 1, tradução nossa.

${ }^{27}$ ROCCO, Alfredo. La Sentenza Civile, cit., passim, tradução nossa.
} 
processualista indaga se não está na hora de repensarmos o fenômeno processual, do ponto de vista da técnica. ${ }^{28}$

\subsubsection{A tutela jurisdicional como resultado em favor do vencedor e perspectiva do vencido}

Desde logo, parece não haver dúvida que a expressão tutela jurisdicional presta-se a designar o resultado da atividade jurisdicional - assim considerados os efeitos substanciais jurídicos e práticos que o provimento final projeta ou produz sobre dada relação material - em favor do vencedor. ${ }^{29}$ A tutela jurisdicional, portanto, deve ser considerada como a análise do fenômeno processual do ângulo de quem tem razão. Assim como ela, quase todos os fenômenos processuais levam em conta os dados fornecidos pela situação da vida regrada pelo direito material, o que revela o nítido caráter instrumentalista do direito processual.

A esse respeito, Flavio Luiz Yarshell afirma que no processo de conhecimento a tutela - consubstanciada na sentença de mérito - pode beneficiar tanto ao autor quanto ao réu, dependendo de quem venha a lograr êxito; no processo de execução apenas se cogita de uma tutela em favor do exequente, visto que aí somente são praticados atos materiais de invasão da esfera individual do devedor, para satisfação do credor; e no processo cautelar não há autêntica prestação de tutela, exceto se admitida a tese de um direito substancial de cautela, ou se admitida a atuação direta do direito material por essa forma de processo. ${ }^{30}$

No sentido apontado, parece haver uma certa sinonímia ou equivalência entre as locuções tutela jurisdicional e tutela de direitos. A tutela de direitos é a defesa do direito diante de sua violação ou ameaça de violação, relacionado intimamente com a própria

\footnotetext{
${ }^{28}$ BEDAQUE, José Roberto dos Santos. Efetividade do Processo e Técnica Processual. cit., p. 77. Eis as questões muito bem postas pelo autor: "não existem ainda resquícios do tecnicismo, com manifestações, muitas vezes inconscientes, de amor obsessivo aos valores do próprio processo, que acabam prevalecendo sobre o fim pretendido e representado pelo resultado produzido no plano substancial? Não estaria a ineficiência do processo ligada - em grande parte, pelo menos - à má aplicação das regras destinadas a regular seu desenvolvimento ordenado? Não há, por parte do processualista, visão excessivamente formalista do fenômeno processual, que outra coisa não é senão método destinado à solução de litígios? Não estaríamos valorizando demasiadamente as formas e os meios, em detrimento do objetivo visado?" (ob. cit., p. 77).

${ }^{29}$ YARSHELL, Flavio Luiz. Tutela Jurisdicional e Tipicidade. Tese de Doutoramento na Universidade de São Paulo, 1997, p. 18.

${ }^{30}$ YARSHELL, Flavio Luiz. Tutela..., cit., p. 19. No processo de execução o exame do mérito fica reservado a eventual processo cognitivo autônomo de embargos, do qual pode resultar tutela em favor do executado.
} 
efetividade do ordenamento jurídico, isto é, fenômeno situado originariamente no plano substancial do ordenamento. Pode ela ocorrer dentro ou fora do processo. Daí falar-se em tutela jurisdicional dos direitos no caso da tutela ocorrer mediante o exercício da jurisdição. $^{31}$

De outra parte, o processualista Yarshell alerta que o conceito de tutela jurisdicional poderia ser considerado sincrético ou, quando menos, calcado na premissa da ação como direito concreto, ou seja, como direito a um provimento favorável. Ambos estão incorretos, pois a associação da locução tutela jurisdicional ao resultado favorável não infirma a autonomia conceitual do processo em relação ao direito material ${ }^{32}$, sem falar que dizer que tutela jurisdicional é tutela de quem tem razão não significa a aceitação da teoria concretista da ação que, conforme sabido, sujeita a existência desse direito ou poder a uma vontade concreta do direito em favor do autor. ${ }^{33}$

Além da compreensão de tutela jurisdicional como proteção do titular de uma situação amparada pela norma substancial, parece possível, segundo Yarshell, admitir maior abrangência à expressão para com ela designar não apenas o resultado do processo, mas igualmente os meios ordenados e predispostos à obtenção desse mesmo resultado. A tutela também poderia ser divisada no próprio instrumento, nos atos que o compõe e ainda nos princípios, regramentos ou garantias que lhe são inerentes. ${ }^{34}$

\footnotetext{
${ }^{31}$ YARSHELL, Flavio Luiz. Tutela..., cit., p. 20/21.

${ }^{32}$ YARSHELL, Flavio Luiz. Tutela..., cit., p. 21/22. Neste sentido, embora sabidamente situados em planos distintos, ação e processo têm natureza instrumental e sua existência é ordinariamente conexa a uma situação de direito material; ao menos a uma situação afirmada pelo demandante. Por isso, nenhuma estranheza deve causar a conceituação de um instituto processual levando em conta um dado de direito material; tanto mais quando se trata do ato final do processo, destinado precisamente a projetar efeitos para fora dele, isto é, para o plano substancial (p. 22).

${ }^{33}$ A esse respeito, BEDAQUE afirma que o ato cognitivo que rejeita a pretensão do autor confere tutela jurisdicional ao réu, pois elimina definitivamente a possibilidade discussão a respeito daquele direito considerado inexistente. O processo de execução tem como resultado único, institucional, a atuação da vontade concreta do direito a favor do exequente, ou seja, tende a um provimento satisfativo. A sentença de improcedência reconhece que o autor não tem direito à tutela jurisdicional, pois não possui interesse juridicamente protegido pelo ordenamento. Tal provimento, contudo, confere tutela ao réu, na medida em que lhe assegura o direito à integridade de sua esfera jurídica. Embora não tenha ele direito subjetivo, tem interesse na não ofensa à sua esfera jurídica, interesse passível de proteção por meio da tutela jurisdicional. Nessa mesma linha, o autor ainda sustenta que a ação declaratória negativa serve para veicular o direto à proteção da esfera jurídica, pois seu autor não deduz direito subjetivo contra o réu. Afirma que a inexistência de qualquer direito do réu impede seja ameaçada ou lesada sua esfera de interesses, juridicamente tutelada. Aqui não há direito subjetivo, mas assegura-se a integridade da esfera jurídica do autor. É a mesma tutela conferida ao réu nas declaratórias positivas, condenatórias ou constitutivas julgadas improcedentes (Direito $e$ Processo..., cit., p. 38/39).

${ }^{34}$ YARSHELL, Flavio Luiz. Tutela..., cit., p. 23/24.
} 
Neste sentido, quando se analisa a chamada tutela jurisdicional diferenciada não se cogita apenas do resultado substancial a ser proporcionado ao titular de uma posição jurídica de vantagem, mas também dos meios predispostos à consecução desse resultado. $\mathrm{O}$ mesmo com relação à tutela específica, que embora se refira essencialmente ao resultado substancial do processo, não deixa de considerar os meios ordenados à produção desse resultado. $^{35}$

A distinção entre resultado e meios é importante, pois quando se cogita de remédios ou de instrumentos para a efetivação de direitos ou interesses materiais, por vezes consideram-se os próprios efeitos substanciais que o processo deve ser apto a proporcionar, por vezes os meios hábeis a conduzir a tais resultados.

Diante da premissa da tutela contida nos meios que conduzem ao resultado, é necessário existir tutela para ambos os sujeitos parciais do processo. Neste sentido, é possível ir além e admitir-se que o Estado também presta tutela jurisdicional ao vencido, embora de forma diversa daquela prestada ao vencedor. ${ }^{36}$ Assim, no mínimo quanto à pacificação pela eliminação da controvérsia, que é o principal escopo do processo - escopo social. $^{37}$

De outra parte, a lei processual também prevê tutela em favor do executado, sem que para isso seja preciso recorrer à ideia de embargos do devedor, como a regra do art. 620 do Código, que impõe a satisfação do credor mediante o menor sacrifício possível do patrimônio do devedor, ou no caso de carência da ação executiva, decorrente da inadequação da via eleita por ausência de título executivo.

\subsubsection{Jurisdição e tutela jurisdicional}

\footnotetext{
${ }^{35}$ YARSHELL, Flavio Luiz. Tutela..., cit., p. 24/25. O professor ainda sustenta que a própria antecipação da tutela reforça, de certa maneira, as asserções feitas: se providência dessa natureza representa forma -ainda que provisória- de atuação do próprio direito material e, considerando que o beneficiário da antecipação pode não ostentar o direito afirmado, é inarredável o reconhecimento de que existe tutela, ainda que provisória, em prol de quem não está amparado pelo direito material. Vale dizer: os meios atuam, ainda que provisoriamente, em prol de quem não tem razão (p. 25/26).

${ }^{36}$ YARSHELL, Flavio Luiz. Tutela..., cit., p. 32/33.

${ }^{37}$ YARSHELL, Flavio Luiz. Tutela..., cit., p. 33/34. Com efeito, mesmo reconhecendo que as partes buscam exclusivamente a tutela de seus interesses, é inegável que ambas esperam do provimento estatal que defina a relação material objeto da disputa, superando a controvérsia, eliminando-a e restabelecendo a paz, entendida esta apenas como sinônimo de estabilidade e segurança.
} 
Inicialmente, verifica-se que não há identidade entre jurisdição e tutela jurisdicional. Enquanto a primeira designa atividade estatal, a segunda designa proteção (tutela) que se proporciona através do exercício dessa atividade. Tal proteção não reside apenas no resultado final, no produto da atividade, mas também no meio empregado para seu exercício. ${ }^{38}$

É certo que os fenômenos estão interligados e que sua separação decorre de uma postura metodológica, não tendo como desligar as vias de ingresso em juízo do resultado esperado pelo demandante, já que o exercício da ação visa principalmente à obtenção desse resultado. Por isso que, segundo Yarshell, falar na eventual tipicidade de uma ação a partir do pedido deduzido pelo demandante, é falar da eventual tipicidade da própria tutela, aqui entendida como resultado. ${ }^{39}$

A jurisdição, como atividade típica do Estado, traduz-se na investidura, que é reconhecida pela generalidade da doutrina como sendo um dos pressupostos processuais, afirmando-se inclusive que a jurisdição é indeclinável. Essa mesma tipicidade traduz-se igualmente na regra do juiz natural e na improrrogabilidade da jurisdição. ${ }^{40}$

Por outro lado, é preciso reconhecer a atipicidade da tutela jurisdicional, no sentido de que, ao menos em princípio, não há um rol previamente estabelecido de provimentos aptos à proteção de direitos e interesses materiais. Além disso, é preciso ter em conta que as formas de tutela ou os tipos de provimento são estabelecidos a partir da situação substancial, que estabelece não apenas qual o bem da vida a ser proporcionado ao autor, mas também a eficácia jurídica apta a conduzir a esse bem. Assim, conclui Yarshell que a tutela jurisdicional deve ser buscada primeiramente no direito material, indagando-se, depois, qual o provimento apto à produção de tais ou quais efeitos substanciais autorizados pelo direito material. $^{41}$

\footnotetext{
38 YARSHELL, Flavio Luiz. Tutela..., cit., p. 197.

39 YARSHELL, Flavio Luiz. Tutela..., cit., p. 198. Nesse sentido, o autor conclui que não deve causar estranheza o fato de, ao se tratar deste ou daquele tipo de tutela (no sentido de resultado), fazer-se menção, novamente, a esta ou aquela ação. Não há aí quebra de sistematização, mas mero e consciente emprego de terminologia corrente, imprescindível para a localização e entendimento do fenômeno escolhido para análise. Da mesma forma, afirma que o exame que se passa a fazer não impedirá que, incidentalmente, retorne-se ao tema do ingresso em juízo e as vias de acesso para tanto, voltando a se falar em tipos de ação (p. 198/199).

${ }^{40}$ YARSHELL, Flavio Luiz. Tutela..., cit., p. 199/200.

${ }^{41}$ YARSHELL, Flavio Luiz. Tutela..., cit., p. 219. O processualista também sustenta que a atipicidade atende à exigência de universalidade da tutela jurisdicional, no sentido de que o sistema deve estabelecer modelos de provimentos (=resultados) aptos à efetividade de todo e qualquer direito ou interesse material, com o que se
} 


\subsubsection{Tipologia da tutela jurisdicional}

O reconhecimento da atipicidade da tutela jurisdicional não impede, na verdade recomenda, que se busque uma tipologia dessa mesma tutela. É conveniente sistematizar as formas de tutela para as diferentes situações substanciais dela carentes, até para melhor compreensão e desenvolvimento do direito processual. Além disso, tutela é conceito que somente se completa à luz do direito material - tutela jurisdicional de direitos - e, nessa medida, é lógica a busca de semelhante categorização. ${ }^{42}$

A doutrina normalmente divide as tipologias em conta de diferentes critérios, que ora consideram apenas a eficácia processual do provimento, ora consideram aspectos relevantes sob a ótica do plano substancial, ora consideram ambos de forma coordenada.

A primeira das tipologias, denominada como tradicional ou clássica, é composta das tutelas de conhecimento, executiva e cautelar. Dentro da primeira, também classicamente dividem-se em tutelas meramente declaratória, constitutiva e condenatória, ao lado das quais parcela da doutrina ainda cita a tutela mandamental e a executiva em sentido lato. $^{43}$

Tal sistematização procura levar em conta um dado essencialmente processual, ou seja, a natureza do provimento ou a natureza dos efeitos processuais dali decorrentes. Yarshell afirma que essa pureza não se sustenta, ou ao menos não satisfaz plenamente, pois assim como não se completa o pedido imediato sem o mediato, não há como pensar no resultado do processo - exatamente por ser ele instrumental - sem a conjugação das eficácias processual e material do provimento final. ${ }^{44}$

Essa aproximação acaba resultando em outras formas de sistematização que, baseada em diversos critérios, resultam nas tutelas preventiva ou inibitória, sancionatória

obtém um inegável alargamento do acesso à justiça. Em outras palavras, na passagem da atipicidade da garantia da ação para a tipicidade do direito material, é preciso extrair do sistema processual modelos aptos à ligação de um e outro (p. 221).

${ }^{42}$ YARSHELL, Flavio Luiz. Tutela..., cit., p. 222/223.

${ }^{43}$ YARSHELL, Flavio Luiz. Tutela..., cit., p. 223. A respeito da divisão e classificação das tutelas, v. item 1.2.3.

${ }^{44}$ YARSHELL, Flavio Luiz. Tutela..., cit., p. 223. 
ou reparatória, coletiva e individual, específica e genérica, antecipada ou antecipatória. Essa categorização não substitui ou exclui aquela outra processual, pelo fato de que os efeitos substanciais somente são atingíveis através da eficácia processual do provimento. Segundo Yarshell, é precisamente a confrontação dessas tipologias, fundadas em critérios diferentes -mas complementares- que ajuda a visualizar o fenômeno processual. ${ }^{45}$

Ademais, todas essas formas de tutela revestem-se daquela mesma atipicidade e universalidade vigorante para as demais, ou, pelo menos, eventual tipicidade só pode ser identificada no plano material do ordenamento, atingindo o provimento apenas reflexamente. $^{46}$

Diante disso, é importante compreender como a tipicidade se relaciona com a tutela jurisdicional, sob o ângulo do processo. Neste sentido, falar da tipicidade do processo é falar da tipicidade tanto do procedimento - soma dos atos do processo -, quanto da relação jurídica processual. Contudo, entre esses elementos que o compõem, nem sempre será fácil identificar onde a tipicidade diz respeito a um ou outro, podendo ser enfocada sob um ângulo interno, isto é, sob o prisma da forma e do conteúdo dos atos processuais. ${ }^{47}$

Por outro lado, o processo também pode ser visto, sempre com foco na tipicidade, como o instrumento da jurisdição. Sob esse prisma, pensar no processo é pensar no modo pelo qual o Estado desenvolve a função jurisdicional e, ao mesmo tempo, pensar nos caminhos ou remédios postos à disposição do interessado para desencadear o exercício

${ }^{45}$ YARSHELL, Flavio Luiz. Tutela..., cit., p. 267.

46 YARSHELL, Flavio Luiz. Tutela..., cit., p. 267. Segundo o autor, no caso da tutela preventiva (ou inibitória) esse aspecto da atipicidade é particularmente realçado, sendo marcante na doutrina a afirmação de seu caráter atípico, descendente da garantia constitucional da ação. Trata-se de tutela que permite a prevenção do ilícito, no sentido de impedir sua consumação ou, em certos casos, sua continuação ou repetição, sem que isso configure uma atuação propriamente cautelar, à medida que propicia, desde logo, a atuação do direito material. Nesse particular, o sistema processual civil brasileiro dispõe de instrumentos para assegurar essa tutela preventiva, citando-se as regras dos arts. 273 e 461 do CPC, que permitem a antecipação de tutela de forma consideravelmente abrangente, embora com as restrições ali consignadas.

No caso da tutela específica, segundo o autor, não há dúvida quanto à sua atipicidade, independente de autorização legal. A mais perfeita restauração da situação violada resulta do próprio plano substancial, cujas normas devem ser atuadas, cabendo ao processo tão somente a missão de propiciar a quem tenha um direito tudo aquilo a que faça jus. De qualquer modo, o ordenamento brasileiro é taxativo a esse respeito, impondo a primazia dessa modalidade de tutela (art. 461, caput e parágrafo primeiro).

Por fim, quanto à tutela coletiva (em sentido lato), não se pode negar que é prestada nos termos da regulamentação legal. Nessa medida, poder-se-ia falar de uma certa tipicidade dessa modalidade de tutela. Yarshell afirma, contudo, que a questão aí é muito mais da atribuição de legitimação a determinados entes para que, em nome próprio, postulem interesses ou direitos que dizem com uma pluralidade de indivíduos. (p. 268/269).

${ }^{47}$ YARSHELL, Flavio Luiz. Tutela..., cit., p. 271. 
dessa função. Assim, para Yarshell, retorna-se ao tema do ingresso em juízo, não exatamente sob o ângulo da ação, mas sob a ótica do meio colocado à disposição tanto das partes, quanto do próprio Estado para a declaração e atuação do direito. ${ }^{48}$

Na verdade, quando os meios técnicos processuais não são pensados a partir das necessidades do direito material, não há como cogitar o direito de ação como direito à possibilidade da obtenção da tutela prometida pelo direito material. Se assim não fosse, bastaria uma única espécie de sentença, além de meios executivos que, em princípio, devem servir à execução de toda e qualquer tutela jurisdicional.

O princípio da tipicidade dos meios executivos, além de se fundar na desnecessidade de meios executivos diferenciados e adequados ao caso concreto, objetou garantir a liberdade do litigante contra a possibilidade de arbítrio judicial. Tal princípio se tornou possível diante da indiferença em relação ao direito material e com base na preocupação com a defesa da liberdade dos litigantes perante o Estado. ${ }^{49}$

De acordo com referido princípio, os meios de execução devem estar previstos na lei e, por isso, a execução não pode se dar através de modalidades executivas não tipificadas, garantindo o jurisdicionado contra a possibilidade de arbítrio judicial na fixação da modalidade executiva. ${ }^{50}$, característica do processo civil da civil law. Diferentemente, no processo civil da common law deu-se maior poder ao juiz através de multa e prisão (contempt $f$ Court), além de não limitar-se o poder à definição legal das modalidades executivas para poder utilizá-las diante de casos concretos. ${ }^{51}$

No sistema executivo brasileiro, segundo Marinoni e Arenhart, após 1994 passou a constituir um sistema misto. Isto, porque a nova redação ao artigo 461 do código, além de

\footnotetext{
${ }^{48}$ YARSHELL, Flavio Luiz. Tutela..., cit., p. 273.

${ }^{49}$ MARINONI, Luiz Guilherme; ARENHART, Sérgio Cruz. Curso de processo civil, volume 3: execução, cit., p. 60.

${ }^{50}$ MARINONI, Luiz Guilherme; ARENHART, Sérgio Cruz. Curso de processo civil, volume 3: execução, cit., p. 60. A sentença, como meio técnico através do qual o juiz presta tutela jurisdicional, recebe influência da maior ou menor latitude de poder outorgada à jurisdição para a satisfação de direitos. Nesse contexto, a questão que importa diz respeito à relação entre o princípio da tipicidade dos meios de execução e a extensão do poder da jurisdição. (p. 108).

${ }^{51}$ MARINONI, Luiz Guilherme; ARENHART, Sérgio Cruz. Curso de processo civil, volume 3: execução, cit., p. 109. Entende-se na common law que o juiz deve dispor de meios necessários para fazer valer as suas decisões, e por isto não deve ter o seu poder cerceado pela ideia de tipicidade das modalidades executivas (p. 110).
} 
ter dado ao juiz o poder de sancionar as suas decisões - finais ou antecipatórias - com multa, graduando-a conforme as circunstâncias do caso concreto, conferiu-lhe o poder de determinar a modalidade executiva adequada e necessária à tutela da situação litigiosa. $\mathrm{O}$ mesmo espírito foi adotado pelo artigo 461-A, acrescentado pela lei 10.444/2002, que atribuiu poder ao juiz para trabalhar com a modalidade executiva adequada à tutela jurisdicional que depende da entrega de coisa. ${ }^{52}$

Essas alterações, somadas à instituída no sistema executivo pela lei 11.232/05, serão, portanto, objeto de estudo aprofundado, de forma a verificar como o legislador modificou conceitos e o próprio sistema, e quais os efeitos dessas alterações no direito processual civil.

\subsection{Sentença judicial}

\subsubsection{Sentença como técnica processual}

É preciso insistir na distinção entre tutela jurisdicional e sentença para evidenciar que a sentença é apenas uma técnica processual, elaborada pelo legislador, para propiciar as tutelas prometidas pela Constituição e pelo direito material. ${ }^{53}$ Técnica indispensável, portanto, para que o Estado possa dar respostas efetivas às pretensões sociais, característica marcante do Estado Democrático de Direito.

Neste sentido, entende-se por técnica a predisposição ordenada de meios destinados a obter certos resultados. Toda técnica, por isso, é eminentemente instrumental, no sentido de que só se justifica em razão da existência de alguma finalidade a cumprir e de que deve ser instituída e praticada com vistas à plena consecução da finalidade. A técnica está a serviço da eficiência do instrumento, assim como este está a serviço dos objetivos traçados pelo homem e todo o sistema deve estar a serviço deste.

\footnotetext{
${ }^{52}$ MARINONI, Luiz Guilherme; ARENHART, Sérgio Cruz. Curso de processo civil, volume 3: execução, cit., p. 112.

${ }^{53}$ MARINONI, Luiz Guilherme; ARENHART, Sérgio Cruz. Curso de processo civil, volume 3: execução, cit., p. 97.
} 
Técnica processual, por sua vez, é "predisposição ordenada de meios destinados à realização dos escopos processuais". 54556 José Roberto dos Santos Bedaque considera a técnica processual em sentido mais amplo, para compreender os momentos de formulação e interpretação da norma processual, além do método de ensinar o direito processual: elaboração, conhecimento e interpretação. ${ }^{57}$

A técnica processual está posta e há de ser empregada empiricamente a serviço dos diversos escopos predeterminados. Nos últimos tempos, vem se agitando visando adaptarse às exigências sociais e políticas que atuam sobre o sistema processual e lhe cobram o cumprimento de seu compromisso com o Estado e com a própria sociedade. Como tem a missão de ordenar meios à consecução harmoniosa dos escopos do processo, inclusive atendendo a solicitações contrapostas, a técnica processual se torna assim complexa e problemática, além de instável nas soluções apresentadas. A tendência hoje, segundo Dinamarco, é caminhar no sentido de aumentar o peso que, nesse jogo de valores, tradicionalmente é dado às exigências ligadas aos escopos sociais. ${ }^{58}$

Mediante as técnicas adotadas na lei, o legislador mostra-se sensível ao clamor social pela realização daquilo que compete aos juízes, ou seja, pelo cumprimento do serviço de eliminar rapidamente os litígios, “com firmeza e ponderadamente sim, mas na

\footnotetext{
54 Essa é, intencionalmente, uma conceituação teleológica da técnica, não valendo a pena a busca de uma definição puramente técnica da técnica, ou seja, definição só instropectiva, cega para os propósitos do sistema (Dinamarco, A instrumentalidade do processo, cit., p. 275).

55 Barbosa Moreira, a esse respeito, afirma que "com má técnica não se conduz a bom termo processo algum. É indispensável, portanto, que os processualistas se ocupem da técnica. Se não o fizerem, ninguém mais o fará: decididamente não havemos de esperar (nem, aliás, de desejar...) que se disponham a suprir nossa omissão economistas, sociólogos ou especialistas em ciências políticas" (Os novos rumos do processo civil brasileiro, In RePro, vol. 78, pp. 141/142).

${ }^{56}$ BEDAQUE aponta dois grandes objetivos da técnica processual: a) conferir segurança ao instrumento, no sentido de proporcionar absoluta igualdade de tratamento aos sujeitos parciais do processo, possibilitandolhes influir substancialmente no resultado; b) garantir seja a tutela jurisdicional, na medida do possível, resposta idêntica à atuação espontânea da regra de direito material, quer do ponto de vista da justiça da decisão, quer pelo ângulo da tempestividade (ob. cit., p. 77/78).

${ }^{57}$ BEDAQUE, José Roberto dos Santos. Efetividade do Processo e Técnica Processual. cit., p. 74.

58 Dinamarco, A instrumentalidade do processo, cit., pp. 276 e 280. A glória da boa técnica processual é o compromisso com a verdade, que, todavia, será motivo de sua miséria quando levado a extremos indesejáveis. A boa técnica processual incumbe o estabelecimento do desejado racional e justo equilíbrio entre as duas exigências opostas (conhecimento e ignorância), para que não se comprometa a qualidade do resultado da jurisdição por falta de conhecimento suficiente, nem se neutralize a eficácia social dos resultados bem concebidos, por inoportunidade decorrente da demora (pp. 282/283).
} 
medida em que a obsessão pelo cumprimento da lei material não seja fator de demoras intermináveis e insuportáveis pelas partes e pela própria sociedade". ${ }^{56} 60$

Assim, a sentença resulta da confluência, no processo de cognição, do direito de ação e do poder de jurisdição. Parece correto afirmar que a sentença representa, em face da lei, genérica e abstrata, uma nova manifestação de vontade do Estado, através do órgão jurisdicional, pela qual, particular e especificamente, o comando legal atua, por força de uma norma secundária, garantia e tutela do ordenamento jurídico. ${ }^{61}$

Na realidade, o que mais comumente ocorre no processo de conhecimento é que o juiz não decide somente a demanda do autor, mas as demandas contrapostas das partes. A tutela jurisdicional será deferida, pela sentença de mérito, àquele cuja pretensão for acolhida pelo juiz.

Determinadas formas de tutela, como as tutelas declaratória e constitutiva, são satisfeitas apenas com a prolação da sentença. São consideradas satisfativas, mas tal satisfatividade decorre do fato de prestarem tutelas que não reclamam nada além da sentença, dispensando as formas executivas. Isso implica que o processo, após a prolação da sentença, só caminha adiante quando a tutela do direito não foi integralmente prestada, dependendo de meios de execução. Nesse caso, a sentença não é bastante para a prestação da tutela do direito material. ${ }^{62}$

É neste sentido que se afirma não consistir a tutela jurisdicional na prolação da sentença em si mesma, mas que é produzida pela sentença e pelos efeitos que projeta sobre a vida das pessoas. A sentença de mérito é somente o meio de oferta dessas situações melhores por obra dos juízes, ou seja, modo de oferecer a tutela jurisdicional. Esse é um

\footnotetext{
59 Dinamarco, A instrumentalidade do processo, cit., p. 302. O autor sustenta que as técnicas processuais da cautelaridade e da antecipação de tutela incluem um bom sistema de freios e contra-pesos dos riscos, capaz de minimizá-los a nível mais do que aceitável e de oferecer compensação pelos males eventualmente impostos em razão da efetivação das medidas cautelares (p. 320).

60 Sálvio de Figueiredo Teixeira, a esse respeito, sustenta que "cabe aos especialistas da técnica processual encontrar caminhos mais rápidos e eficazes, descortinar vias alternativas para a solução dos conflitos, cada vez mais presentes no cenário mundial, maximizar o valor dos princípios, orientar corretamente os que a lei interpretam, para que ela tenha, nas mãos do seu aplicador, o seu verdadeiro alcance, através de métodos modernos de exegese que ponham em relevo os altos propósitos da ciência processual, de efetividade e justiça substancial" (A efetividade do processo e a reforma processual, In RePro, vol. 78, p. 88).

${ }^{61}$ PARÁ FILHO, Tomás, ob. cit., p. 23.

${ }^{62}$ Acerca da execução e do cumprimento da sentença, ver capítulo 2.
} 
dos aspectos da efetividade do processo como meio de proporcionar a tutela jurisdicional processo civil de resultados.

O Código de Processo Civil prevê nos artigos 458 a 466-C os requisitos e os efeitos da sentença.

\subsubsection{O conceito de sentença}

O vocábulo sentença origina-se do latim sententia e traz a ideia da manifestação do juiz sobre o modo como ele sente a causa e as pretensões contrapostas dos litigantes. ${ }^{63}$ Segundo leciona Giuseppe Chiovenda, o conceito romano tinha a sentença como ato final, que continha a absolvição ou condenação, que continha, por conseguinte, o reconhecimento ou a negação do bem da vida deduzido em juízo, coisa bem distinta dos pronunciamentos necessários no curso do processo (“interlocutiones"). ${ }^{64} 65$

Para o autor italiano Alfredo Rocco, sentença é o ato pelo qual o Estado, através do órgão jurisdicional a que é destinado (juiz), aplicando a norma ao caso concreto, define qual tutela jurídica o direito objetivo concede a um determinado interesse. ${ }^{66} \mathrm{O}$ também processualista italiano, Giuseppe Chiovenda define a sentença como o pronunciamento sobre a demanda de fundo, ou mais precisamente a resolução do juiz que afirma existente ou inexistente a vontade concreta da lei deduzida em juízo. ${ }^{67}$

José Carlos Barbosa Moreira, por sua vez, define sentença como o ato do juiz que põe fim ao procedimento em primeiro grau, decidindo ou não o mérito da causa. ${ }^{68}$ Alexandre Freitas Câmara, criticando tal posição, define a sentença como provimento

${ }^{63}$ DINAMARCO, Cândido Rangel. Instituições..., vol. II, cit., p. 494.

${ }^{64}$ CHIOVENDA, Giuseppe. Instituciones de Derecho Procesal Civil, trad. E. Gomez Orbaneja, vol. 3, Madrid, Editorial Revista de Derecho Privado, 1954, p. 147.

${ }^{65}$ Sentença, em direito romano, era o ato decisório da causa, o ato pelo qual o juiz decidia do pedido do autor, acolhendo-o ou rejeitando-o. Todos os demais atos decisórios se abrangiam sob a denominação de interlocuciones, decisões de curso no processo, em oposição à sentença, no sentido estrito, ou sentença definitiva, que resolvia o mérito da causa, a res in iudicium deducta (SANTOS, Moacyr Amaral. Primeiras Linhas de Direito Processual Civil. Vol. 3, 23ª Ed., São Paulo: Saraiva, 2009, p. 4).

${ }^{66}$ ROCCO, Alfredo. La Sentenza Civile, cit., p. 28, tradução nossa.

${ }^{67}$ CHIOVENDA, Giuseppe. Instituciones de Derecho Procesal Civil, cit., p. 147. O processualista italiano distingue as sentenças em sentencias definitivas e sentencias interlocutorias, sendo que dessas últimas podem ser subdivididas em sentencias incidentales, sentencias provisionales e sentencias interlocutorias propriamente dichas (p. 148/149).

${ }^{68}$ BARBOSA MOREIRA, José Carlos. Comentários ao Código de Processo Civil, vol. V, $12^{\mathrm{a}}$ ed., Rio de Janeiro: Forense, 2005, p. 415. 
judicial que põe termo ao ofício de julgar do magistrado, resolvendo ou não o objeto do processo. ${ }^{69}$ Celso Neves, a respeito, afirma que a sentença é o ato jurídico processual mais importante, mas é, excepcionalmente, destituído de processualidade, pela circunstância de implicar o termo final do processo como relação jurídica. ${ }^{70}$

O conceito de sentença pode ser encontrado no artigo $162, \S 1^{\circ}$ do Código de Processo, com a redação dada pela Lei Federal 11.232/2005. Segundo o dispositivo, sentença é o ato do juiz que implica alguma das situações previstas nos arts. 267 e 269 do Código. ${ }^{71}$ Tal definição legal é bastante criticada pela doutrina. ${ }^{72}$

Inicialmente, ressalte-se que da referida definição é possível extrair um ponto sobre o qual a doutrina brasileira se mostrou pacífica: a sentença não é, necessariamente, um provimento sobre o mérito da causa, daí resultando a distinção entre sentenças terminativas e definitivas (ou de mérito). ${ }^{73}$

A nova redação dada ao dispositivo abrandou o critério topológico então existente, que definia a sentença como o ato que punha termo ao procedimento de primeiro grau, o que era incorreto na medida em que o procedimento, após a sentença, prossegue para o cumprimento do próprio ato. A rigor, não era a sentença que encerrava o processo, mas o esgotamento das vias impugnativas e o advento da coisa julgada formal. ${ }^{74}$

${ }^{69}$ CÂMARA, Alexandre Freitas. A Nova..., cit., p. 18.

${ }^{70}$ NEVES, Celso. Estrutura fundamento do processo civil: tutela jurídica processual, ação, processo e procedimento. Rio de Janeiro: Forense, 1997, p. 235. Referido processualista cita ainda a doutrina do uruguaio Couture, segundo o qual "el juez actua como um verdadero historiador. Su labor no difure fundamentalmente de la que realiza el investigador de los hechos historicos: compulsa documentos, escucha testigos de los sucesos, busca parecer de los especialistas em determinadas ramas de las ciencias afines, saca conclusiones de los hechos conocidos construyendo por conjetura los desconocidos. En este sentido, el magistrado es el historiador de los hechos que han dado origen al juicio. Su método es análogo y son tambien análogos sus resultados" (Apud Celso Neves, ob. cit., p. 235).

${ }^{71}$ De acordo com Alexandre Freitas Câmara, parece ter o legislador da reforma acolhido o alvitre da Professora Teresa Arruda Alvim Wambier e definido sentença a partir de seu conteúdo, conforme descrito nos mencionados artigos (A Nova Execução de Sentença, $6^{a}$ ed., Rio de Janeiro: Lumen Juris, 2009, p. 21).

${ }^{72}$ A esse respeito, Carlos Alberto Carmona afirma que a definição anterior era equivocada e a nova definição tautológica. Duas definições que, para ele, talvez não precisassem estar no CPC (Ensaio sobre a sentença arbitral parcial. In JAYME, Fenando Gonzaga; FARIA, Juliana Cordeiro de; LAUAR, Maira Terra (coord). Processo Civil: novas tendências: estudos em homenagem ao Professor Humberto Theodoro Junior. Belo Horizonte: Del Rey, 2008, p. 115).

${ }^{73}$ CÂMARA, Alexandre Freitas. A Nova Execução de Sentença, $6^{\mathrm{a}}$ ed., Rio de Janeiro: Lumen Juris, 2009, p. 18.

${ }^{74}$ Nelson Nery Jr e Rosa Maria de Andrade Nery comentam o dispositivo afirmando que houve alteração de rótulo, mas não de essência, pois a lei 11.232/05 manteve inalterado o conceito de decisão interlocutória. Para os autores, não foi apenas o conteúdo do ato que o CPC levou em conta para definir os pronunciamentos do juiz, mas igualmente considerou a finalidade do ato como critério classificatório. Assim, a lei define 
A esse respeito, Marinoni e Arenhart sustentam que não há qualquer razão prática capaz de justificar a alteração dos arts. 162, § $1^{\circ}$, e 463. Para referidos autores, o destempo - e bem por isso inutilidade - das alterações legislativas, na verdade, é fruto da lentidão da doutrina clássica e da jurisprudência em assimilar as necessidades concretas derivadas da evolução do sentido das normas processuais civis. ${ }^{75}$

Alguns doutrinadores passaram, inclusive, a defender que o novo dispositivo possibilita a existência das sentenças parciais. Isto, porque se a decisão do juiz que reconhece a prescrição de um direito, mas prossegue com o processo com relação a outros direitos em discussão na demanda, tal decisão deve ser sentença, por força do art. 269, inciso IV do CPC. Ora, se toda a decisão que implica alguma das situações dos arts. 267 e 269 é sentença, a decisão do exemplo dado também o é, mas parcial, pois nova sentença será dada ao final da fase instrutória com relação aos demais pedidos. ${ }^{76}$

Dessa forma, sustenta parcela da doutrina que existe, hoje, no sistema processual, as chamadas sentenças parciais, ou seja, que julgam parcialmente a demanda levada à juízo, o que possibilitaria haver mais de uma sentença e um mesmo processo, isto é, o "fatiamento" do julgamento. ${ }^{77} 78$ Apesar de o sistema processual já aceitar mais de uma sentença em alguns procedimentos especiais, como o da Ação de Exigir Contas (CPC, art. 915), tal questão se mostra relevante para o processo de conhecimento do Livro I do Código.

A esse respeito, Alexandre Freitas Câmara sustenta que apenas a resolução final do mérito é que pode ser considerada sentença definitiva, capaz de dar por encerrada uma fase

sentença pelo critério misto do conteúdo e finalidade: "sentença é o pronunciamento do juiz que contém uma das matérias do CPC 267 ou 269 e que, ao mesmo tempo, extingue o processo ou a fase de conhecimento no primeiro grau de jurisdição" (Código de processo civil comentado e legislação extravagante, cit., notas 4 e 8, p. 446/447).

${ }^{75}$ MARINONI, Luiz Guilherme; ARENHART, Sérgio Cruz. Curso de processo civil, volume 3: execução, cit., p. 54.

${ }^{76}$ V. item 2.2.1.1.

${ }^{77}$ Para Carlos Alberto Carmona, haverá certamente situações em que o juiz poderá, com vantagem, valer-se das sentenças parciais, devendo o sistema recursal ser adaptado à novidade, já que não é possível imaginar pragmaticamente o manejo de recursos de apelação contra sentenças parciais. A técnica da sentença parcial, para referido processualista, decerto poderá ser bem utilizada por magistrados comprometidos com o princípio da instrumentalidade (Ensaio sobre a sentença parcial arbitral, cit., p. 119).

${ }_{78}$ O Professor Carlos Alberto Carmona, em aula dada na matéria Aspectos Processuais da Arbitragem, no curso de pós-graduação da USP, no primeiro semestre de 2009, defendeu a tese e citou Marcelo Abelha e José Roberto dos Santos Bedaque como outros processualistas a corroborar o entendimento. 
do processo - conhecimento ou execução, conforme o caso. Assim, o provimento final do módulo processual de conhecimento é sentença, seja esse módulo um processo formalmente autônomo ou uma fase de um processo maior. ${ }^{79}$

O legislador, de lege ferenda, atento à discussão, incluiu no projeto de lei do novo CPC, atualmente em fase de análise na Câmara dos Deputados sob o nº 8.046/2010 - após aprovação do Substitutivo ao Projeto de Lei no 166/2010 no Senado em dezembro de 2010 -, a previsão do $\S 1^{\circ}$ do artigo 170 no sentido de que ressalvadas as previsões expressas nos procedimentos especiais, sentença é o pronunciamento por meio do qual o juiz, com fundamento nos arts. 472 e 474, põe fim à fase cognitiva do procedimento comum, bem como o que extingue a execução. Os artigos 472 e 474 preveem as hipóteses de julgamento sem ou com resolução do mérito. E decisão interlocutória será, nos termos do $§ 2^{\circ}$ do art. 170, todo pronunciamento judicial de natureza decisória que não se enquadre na descrição do $\$ 1^{o}$.

Verifica-se que quer-se pôr fim à discussão da possibilidade de cisão do julgamento de mérito em mais de uma sentença - parcial. Contudo, o tema persistirá sendo relevante relativamente ao período de vigência da redação do art. 162, § $1^{\circ}$ do CPC.

\subsubsection{Sentença de mérito}

O artigo 269 do CPC é o dispositivo que prevê o julgamento do processo com resolução do mérito. Para tanto, as condições da ação e os pressupostos processuais terão que ser admitidos como existentes na demanda, para que o juiz possa adentrar no mérito da discussão levada a juízo, dizendo quem tem razão e merecerá ficar com o bem da vida.

Para Cândido Rangel Dinamarco, conceitualmente, só existe julgamento de mérito quando realmente o juiz exerce o poder de optar entre pretensões divergentes. Tal é a primeira das hipóteses do Código (art. 269, I). Legalmente, contudo, haverá resolução de mérito, nos termos do mencionado artigo, também quando o réu reconhecer a procedência do pedido (inc. II); quando as partes transigirem (inc. III); quando o juiz pronunciar a

${ }^{79}$ CÂMARA, Alexandre Freitas. A Nova..., cit., p. 22. 
decadência ou a prescrição (inc. IV); e quando o autor renunciar ao direito sobre que se funda a ação (inc. V). ${ }^{80}$

Para o mencionado processualista, o mérito não está sendo verdadeiramente julgado nessas outras hipóteses, seja porque o juiz não exerce qualquer poder de optar substancialmente - isto é, não julga -, seja porque o julgamento que faz não diz respeito ao objeto do processo, mas limita-se a negar que o autor tenha direito ao julgamento deste decadência. Assim, podem ser considerados falsos casos de julgamento do mérito. ${ }^{81}$

Todo julgamento de mérito contém a declaração de existência ou inexistência de um direito e correspectiva obrigação. Em sentido amplo, declarar é afirmar ou negar. A declaração de existência ou inexistência do direito é um efeito substancial da sentença de mérito, porque se destina a projetar-se para fora do processo e incidir sobre a vida comum dos litigantes, em suas relações. ${ }^{82}$

Nesse sentido, Dinamarco distingue as espécies de sentenças apoiando-se na diferença existente entre a eficácia substancial que cada uma delas tem. Assim, há sentenças cujo único efeito substancial é a declaração da existência ou inexistência de relações jurídicas, direitos e obrigações - daí serem meramente declaratórias - e há as que, além dessa declaração, contêm algum outro elemento que também se projeta para fora do processo e interferirá na vida dos litigantes - constitutivas e condenatórias. ${ }^{83}$

Para referido autor, o segundo momento lógico das sentenças constitutivas consiste na implantação de uma situação jurídica nova - quer mediante a criação de uma relação jurídica antes inexistente, quer pela modificação ou extinção da que existia. Já o segundo momento lógico das sentenças condenatórias é a criação de um título que autorizará a imposição do poder estatal para a satisfação do direito cuja existência está afirmada em seu primeiro momento lógico, sendo que nas condenatórias de cunho mandamental o momento sancionador inclui ainda um comando, ou mandamento a ser obedecido sob pena de o juiz

\footnotetext{
${ }^{80}$ DINAMARCO, Cândido Rangel. Instituições..., vol. III, cit., p. 199.

${ }^{81}$ Idem.

${ }^{82}$ DINAMARCO, Cândido Rangel. Instituições..., vol. III, cit., p. 202.

${ }^{83}$ Idem.
} 
impor sanções e, por seus próprios meios, produzir a realização do resultado estabelecido no preceito. ${ }^{84}$

Como toda decisão judiciária, as sentenças de mérito devem ser suficientemente motivadas, sendo politicamente ilegítimas as que não o forem, porque contrariam o ideal de segurança inerente ao devido processo legal (art. 93, inciso IX, Constituição Federal). Seja no exame dos pressupostos do julgamento do mérito, seja do mérito em si mesmo, é dever do juiz explicar os motivos de suas conclusões, reportando-se à prova dos autos (art. 131 do CPC).

Conteúdo da sentença, segundo José Ignacio Botelho de Mesquita, é o que a sentença diz, é um juízo lógico. Para acolher ou rejeitar o pedido do autor, deve o juiz, na sentença, resolver diversas questões, que dizem respeito à constituição e ao desenvolvimento válido da relação jurídica processual, às condições de admissibilidade da ação e às condições de fato e de direito a que o ordenamento subordina o acolhimento do pedido formulado pelo autor. A resposta a cada uma dessas questões contém um juízo que termina com uma conclusão. ${ }^{85} 86$

Assim como os atos administrativos e as leis, as decisões judiciárias são dotadas de uma eficácia natural, pois que capazes de produzir efeitos. Efeitos da sentença são as alterações que a sentença produz sobre as relações jurídicas existentes fora do processo, por via direta nas relações entre as partes e, por via reflexa, nas relações entre as partes e terceiros. Os efeitos da sentença tanto podem beneficiar como prejudicar terceiros e exatamente por isto admitem-se a assistência, o recurso de terceiro prejudicado e a ação

\footnotetext{
${ }^{84}$ DINAMARCO, Cândido Rangel. Instituições..., vol. III, cit., p. 202/203.

${ }^{85}$ BOTELHO DE MESQUITA, José Ignacio. A coisa julgada. $1^{\mathrm{a}}$ Ed., Rio de Janeiro: Forense, 2004, p. 2. Todas essas conclusões, afirmações do juiz, ou declarações, culminam com uma declaração principal, com base na qual o juiz deve acolher ou rejeitar o pedido do autor. Por força do que dispõe o artigo 469 do CPC só essa declaração principal adquire a autoridade da coisa julgada. É ela que, com o trânsito em julgado da ação, irá se tornar imutável e indiscutível entre as partes (ob. cit., p. 3/4).

${ }^{86} \mathrm{O}$ que o autor pretende em juízo não é apenas um parecer do juiz, uma opinião favorável. O autor pretende uma alteração na situação existente, uma alteração no mundo jurídico. Assim, acolher o pedido do autor é praticar ato - manifestação de vontade - de que depende a produção do efeito (condenatório, constitutivo ou declaratório) pretendido pelo autor. A sentença contém um ato de conhecimento a que se soma uma manifestação de vontade, não diferindo dos demais atos jurídicos. Rejeitar o pedido significa recusar-se a prestar a manifestação de vontade de que dependeria a produção ou efeito pretendido. O juiz expressa essa recusa declarando improcedente a ação (BOTELHO DE MESQUITA, José Ignacio, cit., p. 5).
} 
rescisória do terceiro. A sentença, quando é eficaz, produz efeitos erga omnes. ${ }^{87} \mathrm{Nem}$ todas as sentenças produzem alterações, só as de procedência. ${ }^{88} 89$

Efeito da sentença é sempre uma alteração no mundo do direito. Quando se diz que a uma causa corresponde algum efeito, afirma-se que algo ocorre quando ocorre aquela causa. Se, dado um fato, nada se altera na realidade, este fato não produziu nenhum efeito. Não é causa de nada o ato que não produz efeitos. Neste sentido, a relevância da sentença de improcedência decorre do fato do trânsito em julgado. ${ }^{90}$

Bedaque afirma que as modificações introduzidas pela Lei 11.232/05 não alteraram a situação, de forma que a eliminação do processo de execução autônomo e a criação da fase executiva não conferem maior eficácia prática à sentença. $\mathrm{O}$ credor terá de pleitear as mesmas medidas visando à satisfação do direito, pois a tutela cognitiva não é suficiente, por si só, para afastar a crise de adimplemento verificada no plano material. ${ }^{91}$

A lei processual, preocupada com a qualidade dos julgamentos, estabelece um sistema de recursos, que propicia a revisão dos julgamentos pelos órgãos superiores da jurisdição. Mas nem sempre isso impede que a sentença produza seus efeitos. Em alguns casos a própria lei prevê que determinado recurso não possui efeito suspensivo. ${ }^{92}$

87 BOTELHO DE MESQUITA, José Ignacio, cit., p. 10. A sentença pronunciada entre legítimos contraditores é eficaz tanto em relação às partes como em relação a terceiros (ex. locador, locatário e sublocatário). Ineficaz é a sentença proferida entre ilegítimos contraditores (ausência da verdadeira parte ou sem citação de litisconsorte necessário - arts. 56 e 47 do CPC). Nesses casos, a sentença será ineficaz tanto para o que não participou do processo, como para os que dele participaram.

${ }^{88}$ BOTELHO DE MESQUITA, José Ignacio, cit., p. 2/3.

${ }^{89}$ José Francisco Lopes de Miranda Leão ressalta que a sentença é dotada de eficácia, que pode ser entendida como o conjunto dos efeitos que deve produzir. A efetividade da jurisdição, por sua vez, decorrerá da real produção, no mundo, ou seja, no plano da realidade, de todos os efeitos necessários para que a sentença realmente alcance os escopos que dela são esperados. E a eficiência da atuação jurisdicional decorrerá da capacidade de que o Estado-juiz venha a ser dotado de produzir decisões aptas a alcançar estes escopos, causando no plano da realidade o máximo de efeitos possível no sentido de realmente não apenas dirimir uma querela entre particulares, mas resultar em evidência de atuação do direito objetivo e contribuir reconhecivelmente para pacificação geral.

Assim prossegue no sentido de que a noção de eficiência distingue-se da de efetividade, porque enquanto esta vincula-se a cada decisão em si mesma, depois de proferida, perquirido o grau de interferência que se mostra capaz de produzir, aquela tem um sentido mais genérico, vinculado ao sistema mesmo de produção de decisões. Para utilizar linguagem não jurídica, o mestre em direito afirma que mais eficiente será o sistema que produzir sentenças mais eficazes e efetivas, com o menor custo (ob. cit., p. 41).

${ }^{90}$ BOTELHO DE MESQUITA, José Ignacio, cit., p. 7/8.

${ }^{91}$ BEDAQUE, José Roberto dos Santos. Direito e processo..., cit., p. 43.

92 BOTELHO DE MESQUITA, José Ignacio, cit., p. 7/8. Os efeitos da sentença decorrem da manifestação de vontade nela contida e em princípio se produzem imediatamente. Independem do trânsito em julgado. Podem ser suspensos pela interposição de recursos com efeito suspensivo, mas se produzem integralmente na 
Neste sentido, tanto quanto os atos judiciais de primeiro grau jurisdicional, os acórdãos dos tribunais podem desempenhar no processo uma função de decisão puramente interlocutória, como pode também ter a eficácia de uma sentença. Quanto aos acórdãos de mérito, reproduzem-se os conceitos e regras responsáveis pelas sentenças de mérito, seja no tocante ao seu conteúdo substancial - eficácia meramente declaratória, constitutiva, condenatória -, capítulos de sentença, eficácia natural, momento de eficácia, imunização pela coisa julgada etc. ${ }^{93}$

$\mathrm{O}$ art. 475-N, inciso I, introduzido no Código pela Lei 11.232/05, modificou a previsão do primeiro título executivo judicial, que deixou de ser a sentença condenatória e passou a ser a sentença que reconheça a existência de obrigação de fazer, não fazer, entregar coisa ou pagar quantia. Tal previsão repercutiu na relevância das classificações da tutela, conforme as teorias ternária e quinária, e na distinção entre a sentença condenatória das demais, sob o ponto de vista executivo, tendo em vista que atribuiu-se carga executiva à sentença civil que reconheça a obrigação, independente do "rótulo" declaratória, constitutiva ou condenatória.

\subsubsection{Espécies de tutela e de sentença: análise crítica}

No passado se atribuía à ação qualificações em associação aos direitos subjetivos, em reais, pessoais, patrimoniais, pecuniárias, de prestação de contas, de usucapião etc. Essas qualificações e as classificações das ações, baseadas nelas, eram inerentes à visão imanentista da ação, como nova roupagem que o próprio direito subjetivo adquiria no momento em que lesado. ${ }^{94}$

No direito romano, a finalidade ordinária do processo era uma condenação. Não obstante, é reconhecida a utilização intensa de determinada forma de tutela jurídica, conhecida como praeiudicium, que tendia unicamente a fazer reconhecer e estabelecer judicialmente, para uso futuro, seja para servir num processo, seja para qualquer outro fim, uma relação concreta de direito, ou um fato jurídico, cuja existência era útil verificar. Aí

pendência de recurso que só tenha efeito devolutivo. As exceções a essa regra se acham expressamente previstas em lei.

${ }_{93}$ DINAMARCO, Cândido Rangel. Instituições..., vol. III, cit., p. 220/221.

${ }^{94}$ DINAMARCO, Cândido Rangel. Instituições..., vol. II, cit., p. 326. 
parece ser a origem remota das ações declaratórias, ainda que, na época do seu surgimento, essas questões não comportassem nenhuma autonomia processual. ${ }^{95}$

Da mesma maneira como estavam no direito português das Ordenações Filipinas, as ações provocatórias e as questões prejudiciais passaram para o direito brasileiro mais remoto. ${ }^{96} \mathrm{O}$ CPC de 1939 previu expressamente a ação declaratória, no parágrafo único do

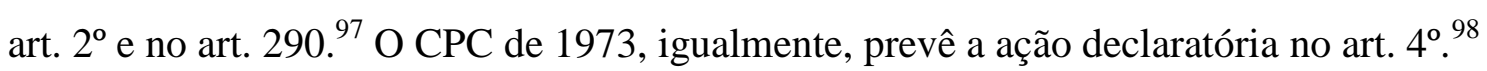

No direito moderno, só é legítimo associar a ação às técnicas processuais de concessão da tutela jurisdicional, sendo que no campo do processo de conhecimento falase em ação condenatória, constitutiva ou meramente declaratória, em correlação com as três espécies de sentenças de mérito. Bedaque afirma que tal classificação é secular e consagrada pela doutrina processual - concepção ternária da tutela jurisdicional. ${ }^{99}$

Essa classificação, para Dinamarco, tem o mérito de ser puramente processual, evitando os critérios herdados da tradição romana e impregnados de elementos inerentes ao direito subjetivo afirmado pelo autor da demanda. ${ }^{100}$ Por outro lado, Bedaque afirma que a classificação das sentenças em meramente declaratórias, constitutivas e condenatórias parte da situação de direito substancial exposta pelo autor e reconhecida ou não pelo juiz - ou

\footnotetext{
${ }^{95}$ LEÃO, José Francisco Lopes de Miranda. Sentença Declaratória - eficácia quanto a terceiros e eficiência da Justiça. Dissertação de mestrado apresentada na Universidade de São Paulo, 1998, p. 12. O autor cita lições de Alfredo Buzaid a corroborar o surgimento histórico da ação declaratória. Em seguida, afirma que a partir da cognitio extra ordinem e de Justiniano, a sentença passa efetivamente a representar o resultado de livre avaliação das provas, emanando do estado e com eficácia derivada disso e não mais da aceitação das partes. No direito medieval, depois das profundas modificações derivadas da influência do direito germânico, a função declaratória manifestou-se principalmente através dos juízos de jactância, de origem germânica com vestimenta romana (passim).

${ }^{96}$ A esse respeito, João Batista Lopes leciona que os juízos provocatórios, conquanto previstos nas Ordenações Filipinas, não conseguiram no Brasil o mesmo êxito de Portugal. Afirma que somente com o Código de Processo Civil do Distrito Federal de 1924 passou a integrar nosso direito positivo. E, sob a influência da doutrina já consolidada, o CPC de 1939 contemplou, de expresso, a ação declaratória (Ação Declaratória. $5^{\text {a }}$ ed., São Paulo: Ed. Revista dos Tribunais, 2002, p. 43/45).

${ }^{97} \mathrm{O}$ art. $2^{\circ}$ previa no parágrafo único que "o interesse do autor poderá limitar-se à declaração da existência ou inexistência de relação jurídica ou à declaração da autenticidade ou falsidade de documento". E o art. 290 previa que "Na ação declaratória, a sentença que passar em julgado valerá como preceito, mas a execução do que houver sido declarado somente poderá promover-se em virtude de sentença condenatória". ${ }^{98}$ Art. $4^{\circ}$. O interesse do autor pode limitar-se à declaração: $\mathrm{I}-$ da existência ou da inexistência de relação jurídica; II - da autenticidade ou falsidade de documento. Parágrafo único. É admissível a ação declaratória ainda que tenha ocorrido a violação do direito.

${ }_{99}$ BEDAQUE, José Roberto dos Santos. Efetividade do processo e técnica processual. cit., p. 510/511.

${ }^{100}$ DINAMARCO, Cândido Rangel. Instituições..., vol. III, cit., p. 208.
} 
seja, é feita à luz da relação material. Na inicial o autor afirma que, nos termos das regras materiais, tem direito aos efeitos pleiteados. ${ }^{101} 102$

A esse respeito, Dinamarco leciona que é mais correto classificar as demandas, como atos de iniciativa destinados a conduzir à emissão da sentença, e não as ações, como diferenciados direitos a esse provimento. Assim, existem demandas de declaração, de constituição e de condenação. ${ }^{103}$

José Francisco Lopes de Miranda Leão, ao tratar das classificações das sentenças, sustenta não parecer correto que seja feita a partir da pretensão contida na demanda que deu início ao processo no bojo do qual vieram a lume, de forma que a classificação não obedece ao pedido formulado pelo autor, mas obedece ao critério dos efeitos diretos que foram concedidos ou negados pelo juiz na sentença. ${ }^{104}$

Contudo, antes de se propor uma classificação das sentenças, é preciso atentar para a função de classificar na teoria geral do direito. Toda classificação trabalha com conceitos, objetivando agrupá-los de forma lógica e cientificamente didática. Uma classificação só é boa se for útil, metodologicamente coerente.

\footnotetext{
${ }^{101}$ BEDAQUE, José Roberto dos Santos. Direito e Processo..., cit., p. 34. O autor afirma que a diferença entre as espécies de tutela decorre das circunstâncias inerentes à situação da vida que clama pela proteção jurisdicional. Na grande maioria das vezes é o próprio direito material que determina a espécie de tutela. Será ela declaratória, condenatória ou constitutiva, por exemplo, em função da relação jurídica substancial e da pretensão exposta pelo autor. As crises de certeza e de adimplemento conduzem, respectivamente, às tutelas declaratória e condenatória. Já, o direito à modificação jurídica (direito potestativo, na terminologia chiovendiana) autoriza a tutela constitutiva. Tanto a tutela declaratória quanto a constitutiva implicam reconhecimento de um direito. Distinguem-se em função da própria natureza do direito afirmado: será constitutiva a tutela se o accertamento acarretar a alteração de um estado jurídico preexistente. $\mathrm{O}$ objeto da declaração, aqui, é o direito potestativo à modificação jurídica (ob. cit., p. 35).

${ }^{102}$ BEDAQUE sustenta tratar-se de fenômeno verificado no plano jurídico-substancial, do qual decorre o tipo de tutela cognitiva adequada. Aliás, para determinadas situações da vida existem tutelas específicas. Daí falar-se que a tipicidade não é da ação, mas da tutela pleiteada. O elemento variável da demanda é exatamente o tipo de tutela, que leva em conta o resultado do processo e que pode ser objeto de classificação. (Direito e Processo..., cit., p. 36).

${ }^{103}$ DINAMARCO, Cândido Rangel. Instituições..., vol. III, cit., p. 208.

${ }^{104}$ LEÃO, José Francisco Lopes de Miranda. Sentenças declaratórias..., cit., p. 26. O autor afirma que classificar as sentenças de acordo com a demanda equivaleria a classificar as sentenças com base no que não está nelas e isso deixaria de fora da classificação as sentenças que deixaram de atender ao pedido, ou o fizeram erradamente. Até porque, se o juiz não atender o pedido, a sentença será sempre declaratória negativa em favor do réu, em nada dependendo, essa classificação, da natureza do pedido. E se o juiz julgar ultra ou extra petita, produzirá ainda assim uma sentença, que deverá ser classificada conforme os efeitos que deva produzir e não conforme o pedido que fora feito.
} 
A esse respeito, Luiz Guilherme Marinoni e Sérgio Cruz Arenhart afirmam que o que vale em uma classificação é o conteúdo e não o nome dos conceitos agrupados. A partir do momento em que se altera o conteúdo de um dos conceitos, modifica-se a classificação, aceitando-se - ainda que inconscientemente - que a classificação modificada não mais serve para explicar os fenômenos. ${ }^{105}$ Os citados autores afirmam que é o que tem ocorrido em relação à sentença condenatória, sugerindo uma nova classificação das sentenças.

A classificação tripartida - ou ternária ${ }^{106}$ - está assente na natureza do provimento jurisdicional pretendido, distinguindo as ações (ou sentenças) declaratórias, condenatórias e constitutivas. Dinamarco divide as sentenças em meramente declaratória, constitutiva e condenatória, inclusive a condenatória mandamental. ${ }^{107108109110}$

${ }^{105}$ MARINONI, Luiz Guilherme; ARENHART, Sérgio Cruz. Curso de processo civil, volume 3: execução. cit., p. 96.

${ }^{106}$ Bedaque afirma que a expressão correta é "ternária", utilizada por Barbosa Moreira. Significa "formado de três", "que se compõe de três unidades". "Trinário" não existe no vernáculo (Efetividade do processo e técnica processual, cit., p. 520, nota 23).

${ }^{107}$ DINAMARCO, Cândido Rangel. Instituições..., vol. III, cit., p. 203. Para referido autor, em síntese, a) a sentença meramente declaratória apenas declara a existência ou inexistência de uma relação jurídica, direito ou obrigação, b) a constitutiva declara a existência do direito a uma alteração na situação jurídica e, em um segundo momento lógico, produz essa alteração; c) a condenatória declara a existência da obrigação e, também, em um segundo momento lógico, institui título para a execução forçada; d) a condenatória mandamental faz o mesmo das demais condenatórias e ainda é dotada de uma eficácia imperativa redobrada, suficiente para gerar sanções pelo descumprimento.

108 Todas as sentenças são suscetíveis de conter na parte dispositiva mais de um núcleo decisório, repartindose pois em capítulos. São capítulos de sentença as partes que ideologicamente se decompõe o decisório de uma sentença ou acórdão, cada uma delas contendo o julgamento de uma pretensão distinta. DINAMARCO, Cândido Rangel. Instituições..., vol. III, cit., p. 199.

109 Ainda segundo DINAMARCO, considerada a função e o conteúdo substancial de cada espécie de sentença, o mais elevado grau de tutela que pode o processo de conhecimento produzir é o oferecido pelas constitutivas, pois ao alterarem desde logo a situação jurídico-substancial lamentada pelo autor, elas não deixam qualquer resíduo litigioso remanescente, eliminando por completo o conflito (tutela jurisdicional plena). A tutela dispensada pelas sentenças meramente declaratórias é plena em relação ao objeto do processo, pois implantam certeza onde o único motivo da lamentação do demandante era a incerteza. As sentenças condenatórias não têm toda essa eficácia sobre o mundo dos conflitos, pois ao declararem existente o direito do autor e assim possibilitarem a execução forçada, elas ficam a meio caminho e a efetivação do direito reconhecido depende sempre de alguma conduta ou medidas futuras. (ob. cit., p. 209/208).

${ }^{110}$ Bedaque afirma que em termos de efetividade do processo, a proteção conferida pela tutela declaratória é plena, pois prescinde de qualquer providência ulterior para assegurar por completo a satisfação da pretensão reclamada. O mesmo ocorre com a tutela constitutiva, que, do ponto de vista prático, opera automaticamente modificação no plano substancial, atendendo integralmente à necessidade de seu titular. Por este mesmo prisma da prestação jurisdicional, a tutela executiva aproxima-se bastante da constitutiva, visto que ambas operam concretamente transformações no plano substancial, satisfazendo plenamente aquela pretensão trazida do mundo exterior. Já a tutela condenatória é a menos completa, pois não dá solução definitiva à situação da vida. Sua utilidade e eficiência prática muitas vezes dependem de outra atividade jurisdicional, agora de natureza satisfativa, consubstanciada na tutela executiva, pois nem sempre o acatamento do direito nela declarado se faz espontaneamente. Por outro lado, Bedaque critica a posição de que a sentença condenatória, a rigor, não acarreta nenhum efeito de direito material, pois traduziria comando já contido na lei, tendo efeitos puramente processuais, já que a obrigação continuaria inalterada. Isso, porque a condenação 
Segundo Tomás Pará Filho, cada qual dessas categorias não prima por rígida tipicidade, podendo-se dizer, de modo geral, que há ações e sentenças de natureza predominantemente declaratória, condenatória ou constitutiva, isto é, a classificação atende à nota dominante. ${ }^{111}$

Pontes de Miranda, inspirando-se no direito alemão, preconizou uma classificação quíntupla - ou quinária -, consoante a qual as sentenças, como as ações, podem ser declarativas, constitutivas, condenatórias, mandamentais e executivas. ${ }^{112}$ Dissentindo da assertiva de que as ações declaratória são meramente (exclusivamente) declaratórias, propõe esse autor, como critério para diferenciar as ações, a preponderância - e não a exclusividade - de seus efeitos. ${ }^{113}$

João Batista Lopes afirma que a classificação de Pontes de Miranda permite identificar, em cada caso, a natureza da ação proposta, explicando muitos problemas não solucionados pela doutrina dominante. Ainda que reconheça ser discutível a validade dessa

pressupõe declaração de existência do direito, o que implica efeitos no plano material, como ocorre com qualquer tutela declaratória (Direito e processo..., cit., p. 42/43).

${ }_{111}^{11}$ PARÁ FILHO, Tomás, ob. cit., p. 35.

${ }^{112}$ A respeito da doutrina de Pontes de Miranda, confira-se a lição de Tomás Pará Filho: "Na sentença mandamental, diz o mestre, o ato do juiz é junto, imediatamente, às palavras (verbos) - o ato, por isso, é dito imediato. Não é mediato, como ato executivo do juiz a que a sentença condenatória alude (anuncia); nem é incluso, como o ato do juiz na sentença constitutiva. Na sentença mandamental, o juiz não constitui: ' $m a n d a$ '. ' $\mathrm{Na}$ ação mandamental, pede-se que o juiz mande, não só declare (pensamento puro), enunciado de existência, nem que condene (enunciado de fato e de valor); tampouco se espera que o juiz por tal maneira fusione o seu pensamento e o seu ato que dessa fusão nasça a eficácia constitutiva. Por isso mesmo, não se pode pedir que dispense o 'mandado'. 'Na ação executiva, quer-se mais; quer-se o ato do juiz, fazendo, não o que devia ser feito pelo juiz como juiz, sim o que a parte deveria ter feito. No mandado, o ato é ato que só o juiz pode praticar, por sua estatalidade. Na execução, há mandados - no correr do processo; mas a solução final é ato da parte (solver débito). Ou do juiz, forçando" (ob. cit., p. 35/36). Para o autor, Pontes de Miranda, ao fazer a classificação pela eficácia, procura indicar a carga ou o peso de declaração, condenação, constitutividade, mandamentalidade ou executividade das sentenças, descambando, segundo parece, para verdadeira apreciação quântica.

${ }^{113}$ Pontes de Miranda, no Tratado das ações, defende: “A preocupação da ciência do direito até pouco foi a de conceituar as ações e classificá-las como se cada uma delas só tivesse uma eficácia: uma fosse declarativa; outra, constitutiva; outra condenatória; outra mandamental; outra executiva. O que nos cumpre é vermos o que as enche, mostrarmos o que nelas prepondera e lhes dá lugar numa das cinco classes, e o que vem, dentro delas, em expectração de efeitos. Não só, por conseguinte, vermo-las por fora, com as suas características exteriores, mas também por dentro. (...) Não há nenhuma sentença que seja pura. Nenhuma é somente declarativa. Nenhuma é somente constitutiva. Nenhuma é somente condenatória. Nenhuma é somente mandamental. Nenhuma é somente executiva. A ação somente é declaratória porque a sua eficácia maior é a de declarar. A ação declaratória é a ação predominantemente declaratória. Mais se quer que se declare que se mande, do que se constitua, do que se condene, do que se execute" (Tratado das Ações, São Paulo: RT, 1970, t. I, p. 124). 
concepção no tocante aos pesos de eficácia, sustenta que o critério básico adotado preponderância dos efeitos - é guia seguro para resolver tão difícil problema. ${ }^{114}$

A respeito, o processualista mineiro Humberto Theodoro Junior considera a classificação quíntupla equivocada, pois leva-se em conta o objeto para as três primeiras e os efeitos para as duas últimas, o que viola a regra de que toda classificação deve compreender todos os objetos do universo enfocado e deve observar um só critério para agrupar as diversas espécies classificadas. ${ }^{115}$

Araken de Assis, por sua vez, sustenta que tal divisão é a melhor, pois nenhuma sentença escapa de uma das cinco classes mencionadas. A cada uma dessas forças, segundo o processualista, corresponde um efeito. ${ }^{116}$

Flavio Luiz Yarshell afirma que, do ponto de vista lógico e sistemático, as categorias executiva e mandamental não estão calcadas no mesmo critério empregado para

\footnotetext{
${ }^{114}$ LOPES, João Batista. Ação Declaratória. $5^{\text {a }}$ ed., São Paulo: Ed. Revista dos Tribunais, 2002, p. 35. O autor faz uma síntese das diversas ações de conhecimento, de acordo com a posição de Pontes de Miranda: a) as ações declaratórias são as que objetivam, preponderantemente, a declaração de existência, ou inexistência, de uma relação jurídica (ex. ação declaratória negativa de débito fiscal). Além dessa eficácia, a sentença declaratória possui, ainda que em menor extensão, outros efeitos (ex. o condenatório, quanto às custas e honorários etc); b) as ações condenatórias, conquanto visem também à declaração de uma relação jurídica, possuem eficácia preponderantemente condenatória, porque objetivam a formação de um título executivo judicial contra o devedor (ex. ação de indenização); c) nas ações constitutivas, também está presente o elemento declaração, mas o que nelas prepondera é a constituição ou desconstituição de uma relação jurídica (ex. ação de anulação de casamento); d) nas ações mandamentais, almeja o autor, preponderantemente, uma ordem, um mandado do juiz para que se faça ou se deixe de fazer alguma coisa (ex. mandado de segurança); e) as chamadas ações executivas lato sensu são assim denominadas porque conduzem a uma sentença que contém, em si mesma, a eficácia executiva, tornando dispensável o processo de execução (ex. ação de despejo, ação de reintegração de posse). Nessa espécie de ação, mesclam-se cognição e execução, de sorte que a concretização da sentença não requer nova citação do réu.

Por outro lado, os pesos de eficácia são critérios pelos quais Pontes de Miranda, pontuando de 1 a 5, indica a preponderância dos efeitos da sentença (ob. cit., p. 35).

115 THEODORO JUNIOR, Humberto. Curso de Direito Processual Civil - Processo de Execução e Cumprimento da Sentença, Processo Cautelar e Tutela de Urgência. 43ª Ed., Rio de Janeiro: Forense, 2008, p. 18. No mesmo sentido, Moacyr Amaral Santos leciona que é possível classificar as sentenças, quanto aos seus efeitos, em sentenças meramente declaratórias, sentenças condenatórias e sentenças constitutivas (ob. cit., p. 29).

${ }^{116}$ ASSIS, Araken de, cit., p. 6/7. Para o autor, através da eficácia declarativa o autor tem por fito extirpar incerteza, tornando indiscutível, no presente e no futuro, graças à autoridade da coisa julgada, a existência, ou não, de relação jurídica, ou a falsidade, ou não, de documento (art. $4^{\circ}$ ); através da eficácia constitutiva o autor busca, além da declaração, a criação, a extinção ou a modificação de uma relação jurídica; através da eficácia condenatória o autor visa a obter a reprovação do réu, ordenando que sofra a execução; através da eficácia mandamental o autor pleiteia uma ordem para alguém, e ninguém mais, adotar um comportamento predeterminado; e, por fim, através da eficácia executiva o autor pede ao juiz que extraia um bem da esfera jurídica do réu e passe para a sua esfera. Ainda segundo o autor, um dos erros mais comuns nesta matéria reside em atribuir tais efeitos exclusivamente ao processo. O processo é um instrumento do direito material e se destina a compor relações litigiosas. Quando inexiste litígio, os efeitos aparecem no seu âmbito natural, que é o das relações não litigiosas. (ob. cit, p. 7).
} 
a tipologia precedente e, sob esse ângulo, não podem ser cientificamente aceitas sem ressalvas, posto que não leva em conta a natureza do provimento jurisdicional, já que o respectivo dado conceitual é exterior ao próprio provimento, dizendo respeito ao modo pelo qual este é efetivado em termos práticos. ${ }^{117}$ De acordo com referido processualista, embora se reconheça que as formas executivas dessas duas situações seja desejável, inclusive como regra mais generalizada, insiste-se em que o diferencial dessas categorias reside no modo pelo qual são praticados os atos de execução. Na realidade, tratam-se de sentenças que impõem prestação, mas que não são remetidas à forma tradicional da instauração de um novo processo de execução. ${ }^{118}$

Já o jurista italiano Alfredo Rocco, afasta a categoria das sentenças constitutivas e defende a dicotomia de sentença: (i) sentenças puras e simples ou sentenças de conhecimento e (ii) sentenças executivas ou sentenças de condenação. Para o autor, as sentenças chamadas constitutivas geralmente assumem a forma de sentença de simples conhecimento, sem que seja excluída em qualquer caso a possibilidade de que, somada a sentença de conhecimento à cominatória específica de execução forçada, se apresente também como sentença de condenação. ${ }^{119} 120$

Alexandre Freitas Câmara afirma que a divergência entre as teorias trinária, quadrinária e quinária decorre da dificuldade em conceituar a sentença condenatória. Para

\footnotetext{
${ }^{117}$ YARSHELL, Flavio Luiz. Tutela..., cit., p. 265. O processualista reconhece que não há dúvida de que o sistema conhece provimentos executivos lato sensu, isto é, que se executam independentemente de novo processo. A respectiva identificação ocorre a partir da autorização legal para que a ordem se cumpra por mandado, isto é, por ordem do juiz (exemplos: casos de despejo, reintegração de posse, ação de depósito e, segundo alguns, ação de desapropriação). Com isso não se abre oportunidade para embargos do devedor, uma vez que não há instauração de uma nova relação jurídica processual. Quando ao provimento mandamental, sustenta que ele tem sido identificado na regra do art. 461 do CPC que, de resto, repete o teor do art. 84 do CPC. A mandamentalidade residiria em que o juiz, ao invés de condenar, emitira uma ordem, cuja inobservância daria ensejo à prática de sanções, tendentes compelir o devedor ao adimplemento (p. 266).

${ }^{118}$ YARSHELL, Flavio Luiz. Tutela..., cit., p. 266.

${ }^{119}$ ROCCO, Alfredo. La Sentenza Civile, cit., p. 145, tradução nossa.

${ }^{120}$ Outro autor italiano, Calamandrei expõe, inicialmente, a diferença entre a sentença condenatória e as demais categorias de sentença sob o ponto de vista gramatical. Afirma que o verbo condenar, diferentemente dos outros verbos que o juiz adota nos demais tipos de sentença ("declaro", "anulo", "revogo") não exaure em si mesmo a própria função, mas tem a necessidade de um complemento indireto, representado pela preposição $a$, para ter significado concreto (se condena a pagar, a restituir, a fazer). Chiovenda salienta que os direitos potestativos somente podem ser determinados por sentença declaratória, por não haver necessidade de imposição de um comportamento jurídico (prestação) à outra parte, já que produzem efeitos jurídicos por simples declaração da parte. Carnelutti diferencia a sentença declaratória pelo fato de que nesta última ocorre a declaração de um ato ilícito, concepção que foi criticada pela doutrina (Apud PALHARES, Cinara. A sentença cível como título executivo judicial - Considerações sobre o art. 475-N, I, do CPC. In BUENO, Cassio Scarpinella; WAMBIER, Teresa Arruda Alvim (coord). Aspectos polêmicos da nova Execução, v. 4. São Paulo: Revista do Tribunais, 2008, p. 86/87).
} 
referido autor, a classificação deve ser feita pelo conteúdo e não pelos efeitos da sentença, o que resulta da divisão tripartida de sentenças de mérito: meramente declaratória, constitutiva e condenatória, podendo a condenatória ser objeto de uma subclassificação em condenação executiva e condenação mandamental. Ou seja, referido jurista exclui as categorias executiva lato sensu e mandamental para incluir na categoria condenatória duas subespécies, a executiva comum e a mandamental, não dando espaço classificatório para a executiva lato sensu. ${ }^{121} 122$

Parece ter razão Humberto Theodoro Junior ao questionar a divisão quinária. Segundo referido autor, mesmo com a introdução dos arts. 461 e 461-A, não houve alteração do conteúdo ou objeto da sentença, mas somente no seu cumprimento. Assim, com a reforma da Lei 11.232/05 todas as sentenças passaram a um regime único de cumprimento e nenhuma delas dependerá mais de ação executiva separada para ser posta em execução, exceto no caso de execução por quantia certa contra a Fazenda Pública e contra o devedor de alimentos. Nem por isso, foi extinto nenhum tipo de sentença quanto ao objeto ou conteúdo, continuando a ser, segundo o conteúdo, declaratórias, constitutivas e condenatórias. $^{123}$

Para referido autor, se fosse para se classificar as sentenças pelos efeitos, elas poderiam ser divididas em (i) sentenças de eficácia interna ou imediata, cuja força eficacial se realiza e se exaure dentro do próprio ato decisório - casos, em regra, das declaratórias e constitutivas - e (ii) sentenças de eficácia externa ou mediata, casos em que os efeitos são produzidos fora do ato decisório, dependendo de atos ulteriores da parte ou do juiz, como se dá nas sentenças que impõem prestações à parte vencida - caso das condenatórias e aquelas que têm eficácia executiva por disposição legal, a exemplo das que homologam acordo, julgam a partilha ou a prestação de contas e até as próprias declaratórias, quando

${ }^{121}$ CÂMARA, Alexandre Freitas. A Nova..., cit., passim. Nesse sentido, a condenatória executiva não se confunde com a chamada executiva lato sensu, mas é a sentença condenatória comum, cuja efetivação se dá por meio de sub-rogação (execução forçada).

${ }^{122}$ Arlete Inês Aurelli afirma que com a Lei 11.232/05 o legislador abandonou claramente a teoria trinária adotada pela maior parte da doutrina para acatar a classificação quinária. Sustenta ainda que no processo de conhecimento as sentenças podem ter mais de uma eficácia, das quais algumas serão preponderantes (AURELLI, Arlete Inês. As principais alterações no regime da execução por quantia certa contra devedor solvente referente a título judicial, trazidas pela Lei 11.232, de 22.12.2005. In WAMBIER, Teresa Arruda Alvim (coord). Aspectos polêmicos da nova execução 3: de títulos judiciais, Lei 11.232/2005, São Paulo: Revista dos Tribunais, 2006, p. 31).

${ }^{123}$ THEODORO JUNIOR, Humberto. As vias de execução..., cit., p. 315. 
acertam não só a existência da relação controvertida como também reconhecem sua violação. $^{124}$

Bedaque, por sua vez, afirma que a classificação quinária, além de não contribuir para o aperfeiçoamento científico do direito processual, também do ponto de vista prático não apresenta grande utilidade. Ao contrário, para referido processualista é teoricamente criticável, visto que fundada em critérios heterogêneos. A aplicação dos conceitos concebidos abstratamente acaba gerando dificuldades práticas desnecessárias. ${ }^{125}$

Neste sentido, a partir da situação de direito material posta em juízo, não há diferença ontológica entre condenar, possibilitando o uso de meios de sub-rogação, e ordenar o adimplemento, com ou sem o uso de meios de coerção. Da mesma forma, não deixa de ser condenatória a sentença apenas porque os atos materiais destinados a efetivála integram uma fase do mesmo procedimento. ${ }^{126127128}$

${ }^{124}$ THEODORO JUNIOR, Humberto. As vias de execução..., cit., p. 315/316, nota 35. Acerca da eficácia executiva da sentença declaratória, v. Capítulo 3.

${ }_{125}$ BEDAQUE, José Roberto dos Santos. Efetividade do processo e técnica processual, cit., p. 517.

${ }^{126}$ BEDAQUE, José Roberto dos Santos. Efetividade do processo e técnica processual, cit., p. 517. O autor ainda afirma que com a Lei 11.232/05 que eliminou o processo de execução, no plano doutrinário são alteradas as cargas de eficácia da sentença condenatória, cuja executividade passa a um primeiro plano; em decorrência, sentença passa a ser o ato de julgamento da causa, com ou sem apreciação do mérito. Observa que a mesma crise de direito material - inadimplemento de obrigação - passa a ser tratada, no âmbito processual, por técnicas diversas. Tratando-se de obrigação de fazer, não fazer e dar, a tutela adequada é a prevista nos art. 461 e 461-A: o juiz emite ordem (sentença mandamental) e a efetivação dá-se no próprio processo cognitivo (sentença executiva). Com relação às obrigações de pagar, a atuação prática da condenação será realizada no mesmo processo (sentença executiva). Para Bedaque, fica patente a falta de uniformidade do critério classificatório: "Enquanto pensamos na natureza da crise de direito material, parece adequada a classificação ternária. Se passarmos a examinar a técnica adotada para efetivação da tutela condenatória, encontraremos a sub-rogação realizada em processo autônomo (sentença condenatória) ou no mesmo processo (sentença executiva), além da possibilidade de a decisão ser acompanhada de ordem (sentença mandamental) (...) Diria que a diferença não está tanto no efeito, que é idêntico em todas: eliminação da crise de direito material. O que caracteriza cada uma é a forma como o efeito se produz: medidas de sub-rogação em processo autônomo ou no mesmo processo, medidas coercitivas, ordens. $O$ cumprimento de sentença condenatória versando sobre obrigação por quantia implica ato de sub-rogação (penhora), a ser efetivado no mesmo processo (art. 475-J do CPC)" (cit., nota 20, p. 518/519).

${ }^{127}$ Bedaque ainda sustenta que as denominadas sentenças executivas ou mandamentais representam mera variação da forma como serão praticados os atos destinados à realização concreto do conteúdo do ato cognitivo: no mesmo processo ou mediante medidas de coerção. Mas em nenhum caso essa atividade tornase desnecessária pela simples modificação da técnica destinada a atuar praticamente a sentença (Efetividade do processo e técnica processual, cit., p. 530).

${ }^{128}$ Além disso, o professor Bedaque afirma que não se consegue ver como a sentença destinada a eliminar crise de adimplemento possa ser suficiente, por si só, para alcançar este objetivo. Sempre haverá necessidade de atos subsequentes, normalmente de natureza sub-rogatória, destinados a fazer com que os efeitos da inatividade do devedor sejam afastados. Em outras palavras, somente após a condenação haverá verdadeira agressão ao patrimônio do réu. Se isso se dá no mesmo processo, ou não, é indiferente para efeito de classificação da sentença, em como não influi na maior ou menor efetividade dela (Efetividade do processo e técnica processual, cit., p. 530). 
A verdade é que, diante da previsão do art. 475-N, inciso I, a distinção entre as espécies de tutela e de sentença parece permanecer relevante apenas em relação às sentenças que não geram título executivo, pois se a sentença civil reconhecer a existência de obrigação de fazer, não fazer, entregar coisa ou pagar quantia, ela será título executivo judicial. Tal sentença permitirá, assim, o cumprimento da sentença, independente de ser declaratória, constitutiva ou condenatória, conforme a classificação mencionada.

Diante disso, mister analisar as espécies de sentença, abrindo-se espaço para as chamadas sentenças executivas e mandamentais - ainda que reconheça-se ser a classificação ternária a tecnicamente correta -, apoiada na classificação de Pontes de Miranda em seu Tratado das Ações.

\subsubsection{Sentença declaratória}

João Batista Lopes leciona que, conquanto já se conhecessem no direito romano ações meramente declaratórias, com caráter prejudiciais, só no século XIX, com a promulgação do Código de Processo Civil alemão (ZPO) que, em verdade, iniciou-se a elaboração científica do instituto. ${ }^{129}$

A sentença meramente declaratória é a mais simples entre todas as sentenças de mérito em sua estrutura lógico-substancial, porque se limita à mera declaração, sem nada lhe acrescentar. Para Dinamarco, é a essência e natureza da sentença declaratória a afirmação ou negação da existência de uma relação jurídica, direito ou obrigação, ou a de seus elementos e quantificação do objeto. O resultado dessa sentença, seja positiva ou negativa, é invariavelmente a certeza quanto à existência, inexistência ou valor de relações jurídicas, direitos e obrigações. ${ }^{130}$

Ação meramente declaratória, assim, é a que tende a simples declaração da existência ou inexistência de uma relação jurídica, ou, excepcionalmente, da autenticidade

\footnotetext{
${ }^{129}$ LOPES, João Batista. Ação Declaratória, cit., p. 38. O autor ainda faz uma análise de direito comparado, citando as leis alemãs, austríaca, portuguesa e argentina, que também preveem a ação declaratória. Por outro lado, ressalta que a lei italiana não contemplou expressamente a ação declaratória, apesar de na prática tal omissão não ter qualquer consequência, já que a doutrina, a partir dos estudos de Chiovenda, jamais negou a sua existência, ainda mais diante de previsão de casos de sentenças declaratórias no Código (sentenze di accertamento), como nos arts. 34 e 221. De outra parte, na Escócia, na Inglaterra e nos EUA também é admitida a ação declaratória (ob. cit., p. 46/49).

${ }^{130}$ DINAMARCO, Cândido Rangel. Instituições..., vol. III, cit., p. 225.
} 
ou falsidade de documento. Funda-se no art. $4^{\circ}$ do CPC, que prevê que $o$ interesse do autor pode limitar-se à declaração. ${ }^{131}$

O interesse, nesse tipo de ação, será a certeza quanto à existência ou inexistência de uma relação jurídica, ou quanto à autenticidade ou falsidade de documento. O pedido imediato é a declaração de certeza e o pedido mediato é a certeza quanto à existência ou inexistência da relação jurídica ou quanto à autenticidade ou falsidade de documento. ${ }^{132} 133$ 134 Será necessário aferir a presença dos indicadores dessa condição da ação, isto é, necessidade e adequação do provimento para remediar a solução lamentada pelo autor.

As sentenças dessa categoria destinam-se a resolver as chamadas crises de certeza, razão pela qual limitam-se a conter um ato judicial que torna certo o que já existia. Na sentença declarativa o juiz se limita a afirmar ou negar a existência de uma situação jurídica anterior, impondo um juízo de certeza, em concreto, função que, segundo Tomás Pará Filho, é a mais autônoma do processo, posto que se não pode alcançá-la de outro modo. E é, também, a mais elevada do processo civil, pois elimina dúvidas e perplexidades que se reúnem em torno do normal desenvolvimento das relações jurídicas. ${ }^{135}$

131 DINAMARCO leciona que, diferente do que acontece em países europeus, no Brasil há dispositivo expresso no CPC autorizando a tutela meramente declaratória nas hipóteses que indica. No tocante à declaração de relações jurídicas, direitos e obrigações, não seria necessária essa explicitude (art. $4^{\circ}$, I), porque o pensamento científico do direito processual civil já evoluiu o suficiente para entender que a disponibilidade dessa espécie de tutela está incluída na garantia constitucional da ação e do acesso à justiça: com ele ou sem a previsão legal, a tutela meramente declaratória estaria no mesmo modo inserida na ordem processual do país. A utilidade do art. $4^{\circ}$ está, segundo o processualista, por isso, circunscrita aos disposto em seu inc. II, o qual autoriza a mera declaração de autenticidade ou falsidade de documento. É regra universal, que no Brasil só comporta essa exceção, a de que não se declara a ocorrência ou inocorrência de fatos (ob. cit., p. 226).

${ }^{132}$ SANTOS, Moacyr Amaral, ob. cit., p. 30.

${ }^{133}$ Interesse de agir é a utilidade que uma tutela jurisdicional pode oferecer ao sujeito. A prospecção dessa utilidade é feita mediante observação dos predicados de necessidade da tutela e da adequação de cada uma das espécies desta em relação à concreta situação lamentada pelo demandante. Sem crise jurídica não há a necessidade de tutela jurisdicional e, portanto, sem crise de certeza não é necessária a tutela meramente declaratória - e daí a ausência do legítimo interesse de agir, que é uma das condições da ação meramente declaratória (DINAMARCO, Cândido Rangel. Instituições..., vol. III, cit., p. 228).

${ }^{134}$ João Batista Lopes defende a tese de que em algumas hipóteses a ação é ajuizada sem que haja incerteza quanto sobre a existência, ou não, da relação jurídica, havendo, ainda assim, interesse de agir (ex. não tomei dinheiro emprestado de A, que, contudo, me molesta com cobrança do valor: vou ao Judiciário pedir a declaração de inexistência dessa dívida; apesar da convicção de que entidade assistencial goza de imunidade tributária, ajuízo a declaratória da imunidade diante de receio da Prefeitura de acionar-me, diante de notícia veiculada). E mesmo nos casos em que exista incerteza ou dúvida, o autor afirma que não se vai a juízo para desfazê-las - afinal, o parecer de um jurista pode dirimi-las satisfatoriamente - mas para se obter declaração com força de coisa julgada (Ação Declaratória, cit., p. 59/60).

${ }^{135}$ PARÁ FILHO, Tomás. A Sentença Constitutiva. Dissertação de concurso à cadeira de direito judiciário civil da Faculdade de Direito da Universidade de São Paulo, São Paulo, 1973, p. 17. 
Ocorre que, a partir da resolução da crise, haverá a proteção da coisa julgada, e é isso que, segundo João Batista Lopes, efetivamente se busca com a ação. O interesse de agir decorre da necessidade e da utilidade do provimento judicial pleiteado. ${ }^{136}$ Referido autor enaltece três aspectos na ação declaratória: a) cuidado especial exigido na petição inicial, b) o critério a ser observado na indicação do valor da causa; e c) admissibilidade da reconvenção. ${ }^{137}$

O direito à certificação reputa-se uma decorrência inafastável do próprio direito de ação e da garantia de acesso à tutela jurisdicional. A esse propósito, basta lembrar que a função declaratória está presente em toda e qualquer modalidade de provimento dito cognitivo, sendo inerente ao próprio exercício da jurisdição. ${ }^{138} 139$

Dessa forma, a possibilidade de invocação da tutela meramente declaratória não decorre simplesmente da regra do art. $4^{\circ}$ do CPC, que para Yarshell poderia não existir e nem por isso deixaria de ser invocável essa modalidade de provimento. O professor ainda afirma que a tutela meramente declaratória é aquela que não apresenta contornos de tipicidade, não se encontrando sujeita, salvo algumas exceções, a qualquer espécie de previsão legal para que possa ser invocada e não está presa a um modelo legal. ${ }^{140}$

\footnotetext{
${ }^{136}$ LOPES, João Batista. Ação Declaratória, cit., p. 60.

${ }^{137}$ LOPES, João Batista. Ação Declaratória, cit., p. 70. Para o autor, particularmente na ação declaratória, exige-se do autor especial atenção na elaboração da inicial, que deverá atender à especificidade dessa forma de tutela jurisdicional. Em primeiro lugar, deve o autor limitar-se a pedir a declaração de existência ou inexistência de uma relação jurídica, que não se confunde com a anulação de ato jurídico, a ser pleiteada em ação constitutiva negativa, nem com pedido de condenação do réu. É possível, contudo, a cumulação de pedidos, conforme art. 292 do CPC. Não pode o autor, também, pedir a declaração de mero fato. Além disso, deverá o autor indicar a vantagem econômica objetivada com a declaração, ainda que seu valor preciso não possa ser desde logo estabelecido, mas pelo menos estimado. Da mesma forma, a reconvenção, que não difere ontologicamente da ação, é admitida em ação declaratória, nos termos da súmula 258 do STF, inclusive com pleito de natureza diversa do deduzido na ação principal, desde que presentes os requisitos da demanda reconvencional (ob. cit., p. 70/76).

${ }^{138}$ YARSHELL, Flavio Luiz. Tutela..., cit., p. 227.

139 A esse respeito, José Francisco Lopes de Miranda Leão ressalta que a constatação de que na ação declaratória não se objetiva nenhuma prestação por parte do réu, mas apenas a declaração judicial de uma relação jurídica, poderia insinuar a ideia de que nessa classe de ações não há pretensão a ser satisfeita, não se enquadrando ela, por isso, no conceito de lide (conflito de interesses qualificado pela pretensão de um dos litigantes e pela resistência do outro). Assim, a inexistência no pedido declaratório de qualquer exigência concreta poderia levar à conclusão de que nas ações declaratórias a atuação do julgador não tem o escopo de dirimir uma controvérsia, ou compor um conflito de interesses, mas antes, talvez, de prevenir o advento desse conflito ou dessa controvérsia. Todavia, o autor explica que essa impropriedade seria decorrência da indevida identificação da ideia de pretensão, no sentido processual, com a de prestação, do direito subjetivo (p. 18-19).

${ }^{140}$ YARSHELL, Flavio Luiz. Tutela..., cit., p. 228/229.
} 
A legitimidade ad causam é comandada normalmente e sem peculiaridades, pela regra de que a tutela jurisdicional só pode ser concedida a pedido do sujeito a quem interessa e em face daquele cuja esfera jurídica será diretamente atingida. ${ }^{141}$

Dinamarco atenta para o fato da impossibilidade jurídica da sentença declaratória para a interpretação de lei em tese ou de cláusulas contratuais, sem afirmar ou negar a existência de uma concreta relação jurídica, direito subjetivo, obrigação ou dever decorrente da interpretação que se pretende. ${ }^{142}$ É juridicamente impossível a sentença declaratória de que um fato ocorreu ou de que não ocorreu, de que o estado de uma coisa é de um modo e não de outro etc, exceto para o caso do inc. II do art. $4^{\circ}$, acerca do incidente de falsidade.

De outra parte, o efeito declaratório da sentença retroage à época em que se formou a relação jurídica, ou em que se verificou a situação jurídica declarada. É, pois, efeito ex tunc. Declarada a existência de um crédito, este se tem por certo desde a data de sua formação; declarada a falsidade de um documento, o efeito da sentença retroage à data em que se verificou a falsificação; declarado nulo o casamento, o efeito da sentença retroage à data em que este se celebrou. ${ }^{143}$

A sentença meramente declaratória será positiva quando afirma a existência do direito e negativa quando a nega. As sentenças que declaram a improcedência da ação, por sua vez, são todas elas meramente declaratórias, pois o seu efeito é meramente declaratório. Julgando improcedente a ação, a sentença nada mais faz do que declarar a inexistência da relação jurídica em que o autor fundamenta a ação. ${ }^{144} 145$ A declaratória

\footnotetext{
${ }^{141}$ Dinamarco atenta para o fato de terceiro que afirma ou nega a existência de direito ou obrigação de que ele próprio não se diz titular. Nesse caso, são ativa e passivamente legitimados à ação declaratória nesse caso, como sempre, os sujeitos envolvidos na relação jurídica afirmada ou negada. Questiona-se porém se também aquele terceiro, que seguramente não tem legitimidade ativa porque não é nem se afirma credor ou devedor, é ou não legitimado a figurar no polo passivo, como litisconsorte necessário na ação declaratória negativa promovida por aquele a quem é atribuída a obrigação. Dinamarco responde de forma afirmativa, por ser ele o responsável pela dúvida objetiva a ser dirimida. Em caso de sair vencido, todos os encargos da sucumbência serão exclusivamente seus, porque foi ele quem deu causa à necessidade da ação declaratória (princípio da causalidade) (ob. cit., p. 231).

${ }^{142}$ DINAMARCO, Cândido Rangel. Instituições..., vol. III, cit., p. 227. Mas a jurisprudência sumulada do STJ diz que é admissivel ação declaratória visando a obter certeza quanto à exata interpretação de cláusula contratual (súmula 181). A jurisprudência brasileira é farta de casos em que se afirma ou nega a admissibilidade da mera declaração (idem).

${ }^{143}$ SANTOS, Moacyr Amaral, ob. cit., p. 31.

${ }^{144}$ SANTOS, Moacyr Amaral, ob. cit., p. 31.
} 
negativa, por sua vez, veicula a pretensão exatamente de negar a existência de um direito subjetivo determinado.

Costuma-se dizer que as sentenças que julgam procedente uma ação declaratória em nada alteram a realidade jurídica, pois seriam um mero retrato da situação existente, reforçado pela autoridade da coisa julgada. É preciso distinguir elemento declaratório e efeito declaratório para verificar o desacerto da afirmativa. A esse respeito, leciona Botelho de Mesquita que se isso fosse verdadeiro, essas sentenças seriam inúteis. Não haveria interesse na declaração que fizesse nascer a ação declaratória. O interesse na declaração surge exatamente a partir da necessidade prática da declaração, enquanto um bem jurídico autônomo. $^{146}$

O pressuposto da ação declaratória é precisamente o fato de que algo se altere com pronunciamento da declaração. Se dela não adviesse alteração nenhuma no mundo das relações jurídicas, ela seria absolutamente desnecessária e a ação seria inadmissível. A alteração consiste num vínculo imposto pela sentença, não só às partes como também a terceiros, e especialmente aos órgãos estatais, que os sujeita a tomar como norma para seus atos jurídicos a declaração pronunciada pelo juiz. ${ }^{147}$

Este é um efeito jurídico que só as sentenças que julgam procedentes a ação declaratória produzem e se tornará mais saliente quando examinarmos os efeitos do trânsito das sentenças em julgado. É importante, no entanto, desde já, registrar a ideia de Mesquita de que todas as sentenças contêm um elemento declaratório, mas só as sentenças que julgam procedente uma ação declaratória produzem efeito declaratório. ${ }^{148}$

\footnotetext{
${ }^{145}$ Neste sentido, Dinamarco afirma que em razão dos contornos e estrutura da tutela declaratória, fala-se comumente em ação meramente declaratória tanto para designar o ato de postular em juízo uma sentença de mera declaração (demanda) quanto o direito de obtê-la. Esse direito, que é direito de ação, está sujeito aos requisitos da ação em geral, sendo natural que a possibilidade jurídica da demanda, o legítimo interesse e a legitimidade ad causam constituam as condições da ação declaratória e, portanto, se reputem incluídos entre os pressupostos de admissibilidade da sentença de mera declaração (Instituições..., vol. III, cit., p. 224).

${ }^{146}$ BOTELHO DE MESQUITA, José Ignacio, cit., p. 8/9. De acordo com o autor, essa é a exata concepção de CHIOVENDA. Imaginar que esse bem jurídico se atinge indistintamente tanto pela sentença que julga procedente como pela que julga improcedente uma ação declaratória, porque ambas retratariam igualmente $o$ statu quo, é ignorar exatamente o que há de essencial na ação declaratória e imaginar que possa construir um bem precisamente o que o autor considera um mal.

${ }^{147}$ BOTELHO DE MESQUITA, José Ignacio, cit., p. 9.

${ }^{148}$ BOTELHO DE MESQUITA, José Ignacio, cit., p. 9.
} 
De outra parte, a tutela declaratória que as sentenças meramente declaratórias oferecem está afirmada em seu tópico dispositivo e não entre os fundamentos - motivação - da decisão tomada, conforme os incisos II e III do art. 458 do CPC. ${ }^{149}$ Na motivação o juiz aprecia os fundamentos postos pela demanda inicial, pela defesa e pelas reflexões dele próprio. As afirmações ou negações postas na motivação da sentença constituem declarações incidentes, ou pronunciadas incidenter tantum. Aquelas contidas na parte dispositiva são emitidas principaliter, ou seja, em caráter principal. Dessa forma, Dinamarco afirma que a tutela jurisdicional é oferecida mediante estas, que têm caráter prático ao consistirem em concretos preceitos imperativos a serem observados pelas partes em suas relações no mundo exterior. ${ }^{150}$

A declaratória também tem importância no controle de constitucionalidade das leis, no sistema concentrado, através da ação direta de inconstitucionalidade (ADIN) e da ação declaratória de constitucionalidade (ADC ou ADECON), conforme previstas no art. 102, I, “a” da Constituição Federal e reguladas na Lei Federal nº 9.868/1999.

Uma das discussões de maior relevância acerca da sentença declaratória é a relativa à interpretação do parágrafo único do art. $4^{\circ}$ do CPC, que prevê ser admissível a ação declaratória, ainda que tenha ocorrido violação do direito. Para Dinamarco, esse dispositivo deve ser lido no sentido de que a tutela meramente declaratória é admissível, tanto quando a condenatória, quando a obrigação tiver sido descumprida mediante a alegação de que inexiste. Assim, para o autor, havendo mero descumprimento da parte do obrigado que não nega ou mesmo confessa dever mas não paga, o mencionado dispositivo não deveria ter a eficácia de dar adequação à tutela declaratória, dada a ausência de qualquer crise de certeza, apesar de reconhecer que os tribunais são liberais a esse respeito e tendem a admitir a ação meramente declaratória mesmo em caso de lide por pretensão insatisfeita. $^{151}$

\footnotetext{
${ }^{149}$ Art. 458. São requisitos essenciais da sentença:

I - o relatório, que conterá os nomes das partes, a suma do pedido e da resposta do réu, bem como o registro das principais ocorrências havidas no andamento do processo;

II - os fundamentos, em que o juiz analisará as questões de fato e de direito;

III - o dispositivo, em que o juiz resolverá as questões, que as partes lhe submeterem.

${ }^{150}$ DINAMARCO, Cândido Rangel. Instituições..., vol. III, cit., p. 225. Neste sentido, segue referido autor afirmando que aquelas, ou seja, as declarações que não passam de fundamentos, são de natureza histórica, teórica ou conceitual: exercem mera função instrumental e têm a finalidade de preparar e justificar a conclusão a ser tomada na parte dispositiva.

${ }^{151}$ DINAMARCO, Cândido Rangel. Instituições..., vol. III, cit., p. 229.
} 
Contudo, a grande discussão que circula em torno da sentença declaratória é se ela passou a ser título executivo com a reforma implementada pela Lei 11.232/05 e a redação dada ao inciso I do art. 475-N do CPC - este o principal objetivo de estudo da presente dissertação. Vem ganhando significativo espaço na doutrina a tese, na medida em que referido dispositivo prevê como título executivo judicial a sentença que reconheça $a$ existência de obrigação de fazer, não fazer, entregar coisa ou pagar quantia. ${ }^{152}$ A esse respeito, deixaremos para expor as posições da doutrina e jurisprudência, bem como os efeitos da atribuição de eficácia executiva à sentença declaratória, para o Capítulo 3.

Marcelo Abelha, neste sentido, afirma que com a redação atribuída ao art. 475-N, I pela Lei 11.232/05, restaram sensivelmente diminuídas as diferenças entre as sentenças condenatórias e declaratórias que reconhecem a obrigação, posto que o meio primário daquela - formar título executivo - agora também existe para a declaração (efeito secundário). ${ }^{153}$

Por fim, cumpre citar a tutela declaratória na ação declaratória incidental, que é uma demanda deduzida no curso de processo pendente, tendo por objeto a declaração de existência ou inexistência de uma relação jurídica prejudicial à causa originariamente instalada no processo (art. $5^{\circ}$ e 325 do CPC). Quer quando proposta pelo réu ou pelo autor, seu julgamento é uma sentença meramente declaratória.

\subsubsection{Sentença constitutiva}

As sentenças constitutivas, correspondentes às ações constitutivas, produzem o efeito de criar, modificar ou extinguir uma relação jurídica. Essas sentenças, como as demais, contêm uma declaração de certeza de relação ou situação jurídica preexistente, mas a isso, como conseqüência, acrescentam um quid, consistente na criação de nova relação, ou modificação ou extinção da mesma relação ou situação jurídica.

\footnotetext{
${ }^{152} \mathrm{O}$ processualista das Arcadas afirma que, embora haja razões muito sérias para continuar afirmando a executividade apenas da sentença condenatória e não da meramente declaratória, segurança quanto a esse ponto só haverá quando a jurisprudência dos tribunais vier a posicionar-se firmemente a respeito (DINAMARCO, Cândido Rangel. Instituições..., vol. III, cit., p. 230).

${ }_{153}$ RODRIGUES, Marcelo Abelha. Manual de execução civil. $4^{\text {a }}$ ed., rev. e atual. Rio de Janeiro: Forense Universitária, 2009, p. 129.
} 
Dinamarco leciona que a tutela jurisdicional constitutiva consiste em dar efetividade ao direito do autor à alteração de uma situação jurídico-material que ele não deseja e pretende eliminar. Ordinariamente é a ordem jurídica substancial que lhe confere o direito subjetivo a modificações dessa ordem, não a lei do processo. A técnica processual representada pelas sentenças constitutivas é somente um instrumental de apoio a esses direitos, oferecido para a efetivação da garantia constitucional do acesso à justiça. ${ }^{154}$

Há nas sentenças constitutivas uma declaração de certeza do direito preexistente, das condições necessárias e determinadas em lei para se criar nova relação, ou alterar relação existente, e aí se manifesta a função declaratória, comum a todas as sentenças; e acrescentam a criação, a modificação ou extinção da relação jurídica, como decorrência daquela declaração, e nisso consiste o seu efeito específico, que as caracteriza - efeito constitutivo. ${ }^{155}$ Opera-se a modificação de um estado jurídico, em mecanismo análogo ao do próprio provimento executivo.

Essa modalidade sentencial bem se distingue das demais. Quanto ao conteúdo, é dotada de eficácia inovativa. Segundo Tomás Pará Filho, nela há, ao mesmo tempo, juízo lógico e imperativo de vontade do juiz, sendo que este ato de vontade, calcado na lei, aparece como causa subordinante de determinada inovação no mundo jurídico. ${ }^{156}$ Contudo, nos primórdios da elaboração do seu conceito, a sentença constitutiva prendeu-se à ideia de direito potestativo, vez que o novo estado jurídico dá-se pela mera declaração de vontade do titular, ou mediante verificação judicial. ${ }^{157}$

A sentença constitutiva realiza, por si mesma, a constituição, modificação ou extinção de uma relação ou estado jurídico. Nesses casos, o juiz não está despegado do imperativo da lei, isto é, também acerta ou declara determinados supostos de fato, afirmando a existência de uma dada situação. Contudo, como essa situação envolve, segundo a lei, a insatisfação de interesses juridicamente protegidos e se trata de hipóteses

\footnotetext{
${ }^{154}$ DINAMARCO, Cândido Rangel. Instituições..., vol. III, cit., p. 254. Em seguida, também afirma que a tutela jurisdicional constitutiva consiste na alteração de dada situação jurídica em benefício daquele que tiver direito a ela - quer se trate de constituição, reconstituição, modificação ou extinção de uma relação jurídicosubstancial. Terá direito a essa tutela só quem, presentes os pressupostos para o julgamento do mérito, tiver também o direito subjetivo material à modificação desejada (p. 256)

${ }^{155}$ SANTOS, Moacyr Amaral, ob. cit., p. 33.

${ }^{156}$ PARÁ FILHO, Tomás, ob. cit., p. 19/20.

${ }^{157}$ YARSHELL, Flavio Luiz. Tutela..., cit., p. 234. Yarshell atribui à doutrina clássica de Chiovenda tal construção.
} 
nas quais os próprios sujeitos não podem ou não querem, por si mesmos, realizar a mudança jurídica, o juiz, através da sentença e fundado na norma legal, efetiva a modificação. ${ }^{158} 159$

Para Yarshell, não obstante a considerável complexidade da questão, parece acertado reconhecer a atipicidade dessa forma de tutela ou, mais exatamente, remeter sua eventual tipicidade para o plano substancial do ordenamento. Assim, todo e qualquer efeito autorizado ou admitido no plano do direito material pode, em tese, ser produzido por provimento jurisdicional. Em outras palavras, basta que o ordenamento preveja a produção, modificação ou extinção de determinados efeitos no plano do direito material. Se, nesse plano, vigora ou não uma regra de tipicidade é questão que o processualista enfrenta essencialmente de modo reflexo. ${ }^{160}$

Exemplos típicos de sentença constitutiva são a que defere uma adoção, de procedência de demanda revisional de aluguel, que decreta a separação judicial extinguindo-se a sociedade conjugal, ou o divórcio, bem como aquela que anula ato jurídico por incapacidade relativa do agente, ou por vício resultante de erro, dolo, coação, estado de perigo, lesão ou fraude contra credores (defeitos do negócio jurídico), ou também a sentença que anula o casamento e que determina a interdição. ${ }^{161} 162$

As sentenças constitutivas, como regra, têm efeito ex nunc, isto é, a partir do presente e projetando-se para o futuro, seus efeitos produzem-se a partir de sentença transitada em julgado. Em alguns casos excepcionais, entretanto, os efeitos são ex tunc,

\footnotetext{
${ }^{158}$ PARÁ FILHO, Tomás, ob. cit., p. 29. Para o autor, a diferença entre sentença condenatória e constitutiva é, sobretudo, de qualidade, pois os elementos componentes de uma e outra, afora o declarativo, são distintos entre si: a constitutiva bastando, por sua força intrínseca, à realização da mudança jurídica, que é o seu objeto, enquanto que a condenatória nem sempre tem o condão de provocar, por si só, o acatamento ao direito nela proclamado, exigindo, frequentemente, a via da execução forçada, para a qual vale como título por excelência.

${ }^{159}$ Dinamarco define a sentença constitutiva como a decisão judiciária de mérito que reconhece o direito do autor à alteração pedida e realiza ela própria a alteração, podendo ser constitutiva positiva, constitutiva modificativa ou constitutiva negativa (ob. cit., p. 257).

${ }^{160}$ YARSHELL, Flavio Luiz. Tutela..., cit., p. 236/237. O autor prossegue afirmando que a questão é particularmente delicada em se tratando de provimentos constitutivos ditos positivos, uma vez que quando se trata de desconstituir um ato jurídico não há dúvida quanto á prévia e necessária previsão legal dos fundamentos que o autorizem. Nas hipóteses em que se produz ou modifica efeitos jurídicos -diversamente de se extinguir- é preciso atentar com rigor para o preenchimento dos requisitos exigidos nesse plano, não sendo dado ao juiz substituir propriamente a vontade das partes, mas os efeitos jurídicos a que estas se obrigaram, ou a que estão obrigadas por lei (p. 237/238).

${ }^{161}$ CÂMARA, Alexandre Freitas. A Nova..., cit., p. 32.

162 SANTOS, Moacyr Amaral, ob. cit., p. 33/34.
} 
retroagindo, como a que anula o negócio jurídico, restituindo as partes ao estado em que antes do ato se achavam. ${ }^{163}$ Ela entra em vigor no seu trânsito em julgado, não havendo execução provisória de sentença constitutiva, exceto quando puder gerar título executivo judicial. ${ }^{164}$

\subsubsection{Sentença condenatória}

Por longa tradição cultivada em todos os ordenamentos jurídico-processuais de origem romano-germânica, como é o brasileiro, o primeiro e mais comum título executivo judicial é a sentença condenatória, à qual a doutrina alude como título executivo por excelência. Tanto é que, até a vigência da lei 11.232/05, o art. 584 previa em seu primeiro inciso como título executivo judicial a sentença condenatória proferida no processo civil.

Para Tomás Pará Filho, o conteúdo da sentença condenatória é, sem dúvida, o mais amplo, nele se discernindo um complexo ato volitivo do Estado, acertando determinada relação jurídica e impondo certo comando sancionatório, e, ao mesmo tempo, criando título apto a provocar a execução. ${ }^{165}$

A sentença condenatória, como as sentenças declaratórias, contém uma declaração de certeza da existência de relação jurídica, a que acrescenta um quid, consistente na atribuição ao vencedor do direito de execução contra o vencido. À declaração de certeza acrescenta a condenação do devedor na obrigação declarada. É a sentença que contém a condenação do réu na obrigação declarada. Condena o réu no cumprimento de uma prestação, razão pela qual também se chama sentença de prestação. ${ }^{166}$

\footnotetext{
${ }^{163}$ DINAMARCO, Cândido Rangel. Instituições..., vol. III, cit., p. 261.

${ }^{164}$ Acerca da possibilidade da sentença constitutiva ser título executivo judicial, v. item 3.1.

165 PARÁ FILHO, Tomás, A Sentença Constitutiva, ob. cit., p. 18. O autor prossegue: "Pode-se dizer, de outro modo, mas na mesma linha de pensamento, que a sentença condenatória impõe, potencialmente, uma situação jurídica preexistente, mediante acertamento e consequente enunciado sancionatório, propiciando, ainda, como título executório, a atualização da mesma imposição. De todo modo, não se altera a relação jurídica material até então existente, a qual, muito ao inverso disso, é pressuposto de todo o correlato tratamento processual. Esse tratamento visa, ou à realização da obrigação, mediante ato próprio obrigado, ou a obtê-la compulsivamente, através da execução forçada, sempre atreita à natureza e aos limites da mesma obrigação, para coagir à sua realização específica ou por equivalente(ressarcimento). Em qualquer caso, como se vê, não há, sob o ângulo estritamente condenatório, falar em inovação ou modificação de preexistente relação ou situação jurídica” (ob. cit., p. 19).

${ }^{166}$ SANTOS, Moacyr Amaral, ob. cit., p. 32.
} 
Toda sentença condenatória é dotada de comando dirigido ao réu, impondo-lhe o comportamento previsto pelo direito material. Refere-se invariavelmente a uma obrigação tendo por objeto um entregar, um fazer, um não-fazer ou um pagar, a ser cumprida pelo obrigado. Para sua efetivação conta-se em primeiro lugar com um satisfativo praticado pelo obrigado, que é a prestação. Prestação (do verbo prestar) significa cumprir. E como a prestação é ainda um fato futuro em relação ao momento em que a condenação é proferida, tais sentenças não produzem por si mesmas o efeito de satisfazer o credor.

Segundo Teori Albino Zavascki, o que se retira de comum na doutrina é que a sentença condenatória - seja ela constitutiva, seja meramente declaratória da sanção identifica, de modo completo, a norma jurídica individualizada, definindo inclusive a consequência jurídica decorrente da inobservância do preceito. Se a essa identificação juntarmos o cunho da oficialidade próprio do ato jurisdicional, teremos alcançado, com o trânsito em julgado, o mais elevado grau de certeza oficial a que se pode chegar, somente superável pela preclusão máxima decorrente do transcurso do prazo decadencial para a propositura de ação rescisória. ${ }^{167}$

A previsão do possível inadimplemento é a razão pela qual as sentenças condenatórias eram, até a lei 11.232/05, expressamente dotadas de eficácia executiva, o que permite ao credor a possibilidade de, com fundamento nelas, promover a execução forçada ou cumprimento da sentença. ${ }^{168}$ Isto, porque depois da lei 11.232/05 e a revogação do art. 584 inc. I, não há mais expressa menção à sentença condenatória como título

167 ZAVASCKI, Teori Albino. Processo de execução: parte geral. $3^{\text {a }}$ ed. rev., atual. e ampl. São Paulo: Editora Revista dos Tribunais, 2004 (Coleção estudos de direito de processos Enrico Tulio Liebman; 42), p. 289. O processualista ainda explica a doutrina que distingue a sentença condenatória da declaratória, criticando a posição de Liebman (a sentença condenatória tem duplo conteúdo e dupla função: em primeiro lugar, declara o direito existente - e nisto ela não difere de todas as outras sentenças - função declaratória; $e$, em segundo lugar faz vigorar para o caso concreto as forças coativas latentes na ordem jurídica, mediante a aplicação da sanção adequada ao caso examinado - e nisto reside a sua função específica, que a diferencia das outras sentenças), no sentido que fazer vigorar a força coativa da sanção não constitui, propriamente, função da sentença condenatória, mas sim da ação executiva que a ela posteriormente segue, de forma que se trata, na verdade, de declarar a sanção a que se sujeita o vencido (Barbosa Moreira). Em seguida, Zavascki explica que Carnelutti via a sentença condenatória como uma sentença de dupla declaração, ou seja, a declaração de certeza do que foi e do que devia ser. Por fim, ainda afirma que Calamandrei, por sua vez, define sentença condenatória como a decisão mediante a qual o juiz individualizará o preceito jurídico concreto nascido da norma, estabelecerá a certeza acerca de qual foi e qual deveria ter sido o comportamento do obrigado e determinará, como consequência, os meios práticos aptos para restabelecer em concreto a observância do direito violado (tradução livre, ZAVASCKI, Teori Albino. Processo de execução: parte geral, cit., p. 288).

${ }^{168}$ DINAMARCO, Cândido Rangel. Instituições..., vol. IV, cit., p. 248. Era a previsão do art. 584, I, do CPC. 
executivo judicial, mas à sentença que reconheça a existência de obrigação de fazer, não fazer, entregar coisa ou pagar quantia. ${ }^{169}$

Em processo civil, condenar significa afirmar imperativamente a existência do direito do autor a receber um bem da vida e aplicar a sanção executiva, de acordo com a doutrina de Liebman, tornando adequada a tutela jurisdicional mediante a execução forçada. Sentença condenatória é, consequentemente, a que produz esses dois resultados, declarando que o direito do autor existe e, ao mesmo tempo, abrindo caminho para a execução. Toda sentença condenatória contém, portanto, dois momentos lógicos: (a) aquele em que a existência do direito é reconhecida, ou declarada e (b) aquele em que cria condições para a execução forçada em caso de não-cumprimento do direito reconhecido. ${ }^{170}$

Esse segundo momento lógico, o sancionatório, é, segundo Dinamarco, rigorosamente idêntico em toda sentença condenatória, porque todas elas contêm uma exortação ao devedor para que cumpra, sob pena de execução. Não obstante algumas diferenças estruturais entre suas diversas subespécies, todas as sentenças condenatórias encaminham aos mesmos resultados. ${ }^{171}$

Esse conceito clássico de sentença condenatória é caracterizado por abrir oportunidade para a propositura de ação de execução forçada.

Na lei processual, diferentemente do que ocorre com a ação declaratória, não há previsão de uma ação condenatória. Contudo, sua admissibilidade decorre diretamente da garantia genérica, ou atípica, da ação, estando as maiores dificuldades do tema situadas no plano substancial. Em outras palavras, é o direito material que ditará quais as prestações devidas ao credor e, consequentemente, imponíveis ao devedor pelo provimento judicial. Portanto, é no plano substancial do ordenamento que se deve buscar eventual tipicidade ou

\footnotetext{
${ }^{169}$ Teori Albino Zavascki leciona que nem toda sentença que fixa sanção é título executivo. Somente pode ser assim considerada a que define sanção cuja incidência (a) importe mudança da realidade fática e, além disso, (b) demande, para cumprimento, ação executória autônoma. Com efeito, o autor explica que há sanções que são impostas por atuação jurisdicional no plano exclusivamente jurídico, sem necessidade de posteriores medidas de transformações dos fatos (Processo de execução: parte geral, cit., p. 289).

${ }_{170}$ DINAMARCO, Cândido Rangel. Instituições..., vol. IV, cit., p. 250/251.

${ }^{171}$ DINAMARCO, Cândido Rangel. Instituições..., vol. IV, cit., p. 251.
} 
atipicidade de tutela condenatória, no sentido de que é naquele âmbito que o juiz deverá identificar as prestações passíveis de imposição ao vencido. ${ }^{172}$

Para Alexandre Freitas Câmara, somente se poderia considerar condenatória uma sentença se ela fosse instrumento idôneo a permitir a instauração da atividade executiva, havendo uma necessária correlação entre condenação e execução. Neste sentido, a execução está fora da sentença condenatória, é algo que lhe é exterior e, por isso mesmo, não pode ser base de sua definição. Dessa forma, conceitua sentença condenatória como aquela que, além de acertar a existência do dever jurídico, impõe ao réu o cumprimento de uma prestação de dar, fazer ou não fazer. ${ }^{173}$

Referido autor está entre os que defende a teoria trinária e preconiza haver dois tipos de sentença condenatória, a que pode ser executada (sentença condenatória comum ou executiva) e a que só pode ser efetivada através do emprego de meios de coerção (sentença condenatória mandamental). A primeira é aquela sentença cuja efetivação pode se dar através do emprego de meios de sub-rogação, como a penhora e expropriação de bens do executado, ou o desconto em sua folha de pagamento, pouco importando se a execução se dará no mesmo processo ou em processo autônomo. A segunda é aquela cuja efetivação se dá exclusivamente através do emprego de meios de coerção, como se dá no interdito proibitório ou nas sentenças que proporcionam tutela inibitória em geral. ${ }^{174}$

A doutrina ainda divide a condenação em ordinária, para o futuro ${ }^{175}$, alternativa ${ }^{176}$ e genérica ${ }^{177}$. O que distingue a condenação ordinária das demais é seu momento

${ }^{172}$ YARSHELL, Flavio Luiz. Tutela..., cit., p. 251/252.

${ }^{173}$ CÂMARA, Alexandre Freitas. A Nova..., cit., p. 36. O conceito está na linha de Dinamarco, pois também divide em dois momentos lógicos, quais sejam, um que contém o acertamento da existência da obrigação e um segundo, propriamente condenatório, em que se encontra o ato judicial que impõe ao demandado o cumprimento de um dever jurídico (dar, fazer ou não fazer).

${ }^{174}$ CÂMARA, Alexandre Freitas. A Nova..., cit., passim. O autor sustenta que as chamadas sentenças executivas (sem a alcunha lato sensu) não podem ser admitidas nem mesmo como subespécie das condenatórias, pois a realização da execução no mesmo processo em que a sentença foi proferida ou em processo autônomo se dá por opção do legislador, e não em razão da natureza da sentença, ou qualquer outro elemento de direito material ou processual (p. 38).

${ }^{175}$ É a sentença que impõe a obrigação de satisfazer no futuro um direito que no presente ainda não é exigível ou que ainda não existe, embora seja provável que venha a existir. A doutrina refere-se também às condenações para o futuro como condenações condicionais, mas a condicionalidade nesse caso não é da própria sentença como ato decisório, o que a tornaria nula (art. 460, parágrafo único). Trata-se de sentença cuja eficácia executiva está condicionada a algum evento futuro, referente ao direito reconhecido (Dinamarco, ob. cit., p. 254).

A doutrina refere-se também às condenações para o futuro como condenações condicionais, mas a condicionalidade nesse caso não é da própria sentença como ato decisório, o que a tornaria nula (art. 460, 
declaratório, que é completo e capaz de eliminar qualquer dúvida, imprecisão ou pendência de qualquer ordem, suscetível de impedir a pronta exequibilidade. Não só afirma que o direito do autor existe e é prontamente exigível, como ainda define e identifica os sujeitos e o objeto da relação jurídica e quantifica os bens que o compõem. Dinamarco o aponta como o título executivo por excelência. ${ }^{178}$

De outra parte, Dinamarco afirma que as condenações aparentes não chegam a ser verdadeiras condenações, pois não têm a eficácia de autorizar autênticas execuções. $\mathrm{O}$ autor leciona que, ainda quando completas em seu momento declaratório, com a precisa identificação da relação jurídica e quantificação de seu objeto, seu momento sancionatório

parágrafo único). Trata-se de sentença cuja eficácia executiva está condicionada a algum evento futuro, referente ao direito reconhecido (Dinamarco, ob. cit., p. 254)

A sentença é explícita no tocante à certeza e à liquidez do crédito, mas por falta de exigibilidade do direito, ou da própria constituição deste, elas não são aptas a propiciar a pronta exeqüibilidade. A eficácia executiva é diferida ao momento em que se vencer cada um daqueles direitos que se adquirem periodicamente (alimentos), ou em que se cumprir o termo (vencimento da obrigação), ou se implementar a condição pendente ou for cumprida a contraprestação devida pelo credor (arts. 475-L, II, 572, 582 e 618, I do CPC) (DINAMARCO, Cândido Rangel. Instituições..., vol. IV, cit., p. 253).

${ }^{176}$ A condenação alternativa se refere a direitos alternativos. Elas não são tão completas quanto as ordinárias porque lhes faltam a precisa identificação e individualização do bem devido, deixando pela frente uma escolha a ser feita. Quando a escolha couber ao credor, ele a fará indicando desde logo na demanda de execução qual dos bens prefere. Cabendo a escolha ao devedor, a execução deve ser precedida de um incidente de concentração e só depois poderão ter início os atos de constrição ou de coação inerentes à execução forçada. O que falta à sentença de condenação alternativa é, assim, o requisito da certeza do direito, a ser satisfeito por um desses modos (DINAMARCO, Cândido Rangel. Instituições..., vol. IV, cit., p. 254/255).

${ }^{177} \mathrm{Na}$ condenação genérica há a declaração de existência da obrigação e da natureza dos bens devidos, mas ao seu momento declaratório falta a quantificação dos bens que constituem o objeto do direito do credor. As condenações genéricas manifestam-se em relação ao an debeatur, ao afirmar que o direito existe, mas não anunciam o quantum debeatur. Ela fica aquém do indispensável para a execução, faltando liquidez ao direito reconhecido, sendo necessário proceder à liquidação de sentença antes de executar. Por outro lado, não são genéricas as condenações cujo quantum possa ser encontrado mediante meros cálculos aritméticos, o que será feito pelo próprio credor ao propor a execução, sem necessidade de um incidente de liquidação. Quando condenam por dinheiro, deixam de fixar a quantia devida. Quando condenam por outras coisas quantificáveis (coisas determinadas pelo gênero e quantidade), definem o gênero e a qualidade dos bens devidos, sem declarar a quantidade devida. Também são chamadas de sentenças ilíquidas, mas ilíquido será o direito e não a sentença.

No caso das condenações genéricas para reparação de danos a direitos individuais homogêneos, nos termos do Código de Defesa do Consumidor, o momento declaratório é ainda mais incompleto que o das congêneres, regidas pelo CPC. Elas são preferidas com eficácia erga omnes, restando ainda a definir o valor devido a cada um dos possíveis lesados e também a própria identificação de quem são os sujeitos lesados (arts. 95 e 97 CDC). Faltam, portanto, o requisito da certeza do direito, porque se omitem quanto aos titulares ativos da relação, e o da liquidez, porque não está presente a indicação dos valores a pagar. A execução dessas condenações genéricas depende sempre do processo de liquidação regido pela legislação especial, onde se definirão os lesados titulares de créditos perante o fornecedor responsável e o montante do crédito de cada um (DINAMARCO, Cândido Rangel. Instituições..., vol. IV, cit., p. 255/256).

${ }^{178}$ DINAMARCO, Cândido Rangel. Instituições..., vol. IV, cit., p. 253. 
é nenhum ou de tanta debilidade no sistema, que não chega a propiciar a efetiva imposição das medidas sub-rogatórias ou coercitivas inerentes à execução forçada. ${ }^{179}$

Podem também ser mencionadas como sentenças condenatórias, segundo Dinamarco, a sentença penal condenatória transitada em julgado (art. $475-\mathrm{N}$, inc. II) ${ }^{180}$, a sentença homologatória de transação ou reconhecimento do pedido de que resulte para uma das partes um dever de adimplir (art. 475-N, inc. III) ${ }^{181}$, a homologação de acordos extrajudiciais $^{182}$, a sentença condenatória estrangeira homologada pelo STJ (art. 475-N, inc. VI) ${ }^{183}$, a adjudicação de quinhão em partilha judicial (art. $475-\mathrm{N}$, inc. VII) ${ }^{184}$ e a sentença arbitral condenatória (art. 475-N, inc. IV) ${ }^{185} 186$.

Alguns atos judiciais, para o efeito de aplicar a vontade sancionatória, assimilam-se funcionalmente ao conceito de sentença condenatória, embora a lei assim não os denomine. São dotados de um momento declaratório em que o juiz afirma o direito de uma das partes, somado a um momento sancionatório, consistente nessa abertura para a execução forçada.

179 DINAMARCO, Cândido Rangel. Instituições..., vol. IV, cit., p. 257. São falsas condenações, ou condenações aparentes, as contidas em sentenças proferidas contra a Fazenda Pública, nas obrigações de pagar quantia. Sua eficácia executiva não vai além de propiciar a chamada execução por precatório e não as medidas coercitivas e sub-rogatórias inerentes a uma autêntica execução forçada. Nenhuma eficácia executiva têm também as sentenças substitutivas da vontade do obrigado. Pode-se chegar ao ponto de entender que tais sentenças mandam que o devedor cumpra a obrigação, mas do não cumprimento não resulta nenhuma abertura para a via executiva com fundamento neste falso título executivo. Trata-se, segundo Dinamarco, de sentença claramente constitutiva, não condenatória, pois é capaz de produzir por si própria todos os efeitos da declaração omitida. Acerca das sentenças substitutivas da vontade do obrigado, o CPC equivocadamente diz que condenam o devedor a emitir declaração de vontade (art. 466-A) (ob. cit, p. 257).

${ }^{180}$ Da soma do artigo 91, inc. I do CPP com o art. 475-N, II do CPC resulta que a sentença condenatória penal equivale à civil como título executivo, uma vez que, ainda que por vias indiretas, ela cumpre a dupla finalidade de declarar o direito e aplicar a vontade sancionatória.

181 Justamente por serem homologatórias, essas sentenças não contêm julgamentos sobre o mérito da demanda, ou seja, elas não a declaram procedente ou improcedente. É, segundo Dinamarco, uma falsa sentença de mérito, apesar de a lei considerar como autêntica sentença de mérito, inclusive ao lhe outorgar a condição de título executivo, desde que haja uma prestação (ob. cit., p. 259/261).

${ }^{182}$ A previsão (que é repetida pelo art. 57 da Lei 9.099/95) veio com o intuito de valorizar os acordos feitos perante os pioneiros juizados informais de conciliação. Só serão aptos a obter condição de títulos executivos aqueles que importem alguma prestação a ser adimplida no futuro por algum dos sujeitos.

${ }^{183}$ O art. 105, I, "i” da CF prevê a homologação de sentença estrangeira pelo STJ, sendo que o ato homologador terá eficácia executiva no Brasil como se a sentença condenatória houvesse sido proferida por juiz daqui. A respeito, v. item 3.5.

${ }^{184} \mathrm{O}$ ato com que no processo de partilha o juiz decide sobre a adjudicação de quinhões aos sucessores é título executivo em favor de cada um destes, para o fim de obter a posse do que lhe pertence. Mas sua inclusão entre os títulos executivos leva em conta somente a eficácia declaratória dessa decisão como ato de partilha, a qual só se impõe entre os sujeitos deste (outros herdeiros ou sucessores), sem nenhuma declaração de direitos perante outras pessoas.

${ }^{185}$ Embora não seja proferida por um juiz, órgão da jurisdição estatal, a sentença arbitral é qualificada pelo CPC como título executivo judicial, o que se justifica tendo em vista que a arbitragem se realiza com vista ao mesmo escopo principal que a jurisdição estatal (pacificação) e seu processo se rege pelos mesmos princípios, nos termos da Lei 9.307/96.

${ }^{186}$ DINAMARCO, Cândido Rangel. Instituições..., vol. IV, cit., p. 258/268. 
Assim são as sentenças proferidas em processo no qual tenha ocorrido a denunciação da lide quando acolherem a pretensão deduzida pela parte em face do litisdenunciado (art. 76), ou as que, em caso de chamamento ao processo, venham a acolher a pretensão do autor (art. 80). Também terá essa característica a sentença que na ação de consignação em pagamento conclui pela insuficiência do depósito realizado pelo autor. ${ }^{187}$

Por fim, ainda cabe mencionar o mandado monitório como título executivo judicial. Contudo, segundo a doutrina de Dinamarco, não se trata de uma condenação e sequer uma decisão de mérito, já que o juiz o emite sem investigar sobre a real existência do crédito e sem pronunciar-se a esse respeito, limitando-se à verificação do documento idôneo exigido pela lei. Dessa forma, o provimento jurisdicional contém somente o momento sancionatório, ainda que de eficácia diferida, sem conter declaração acerca do direito. ${ }^{188}$

\subsubsection{Sentença executiva}

Inicialmente, é importante mencionar que parte da doutrina denomina essa espécie de sentença como executiva lato sensu. Contudo, explica Araken de Assis que tal denominação não segue aquela criada por Pontes de Miranda no Tratado das ações. ${ }^{189}$ Tal designação é utilizada para algumas sentenças condenatórias suscetíveis de serem executadas no próprio processo em que são proferidas, independentemente de iniciativa do titular do direito.

Dinamarco ressalta que a primeira das características citadas diluiu-se por completo a partir de quando todo o sistema executório passou a reger-se pela unidade processual processo civil sincrético. O que ainda perdura é a eficácia peculiar a autorizar a execução de ofício. Elas são raras e excepcionais no sistema, existindo somente na medida em que o direito positivo as institua especificamente, como nas ações de despejo, possessórias, desapropriações imobiliárias e outras. ${ }^{190} 191$

\footnotetext{
${ }^{187}$ DINAMARCO, Cândido Rangel. Instituições..., vol. IV, cit., p. 269.

${ }^{188}$ DINAMARCO, Cândido Rangel. Instituições..., vol. IV, cit., p. 270. Tal processualista ainda afirma que, apesar deste ato judicial não ser sentença, o mandado monitório é suscetível de execução segundo as normas e o sistema do cumprimento de sentença, inclusive com a incidência da multa do art. 475-J, cabendo impugnação.

${ }^{189}$ ASSIS, Araken de. Cumprimento da Sentença. $3^{\text {a }}$ Ed., Rio de Janeiro: Forense, 2010, p. 6.

${ }^{190}$ DINAMARCO, Cândido Rangel. Instituições..., vol. III, cit., p. 251. O autor ainda cita os casos do art. 65 da Lei 8.245/91 (lei do inquilinato) e art. 34 do Dec. Lei 3.365/41 (desapropriações). Em seguida, afirma que é muito estranha a denominação dada a essas sentenças, porque elas são autênticas sentenças condenatórias e
} 
O fato de a sentença executiva depender, assim como a condenatória, de meios de execução direta, de acordo com Marinoni e Arenhart, não as torna homogêneas. $O$ fato de a modalidade executiva ser direta nas duas sentenças é algo irrelevante no contexto em que estão inseridas. A sentença executiva tem como característica principal ser uma técnica que reflete a intenção do legislador em dar ao juiz o poder de utilizar a medida executiva necessária ao caso concreto, reflexo da necessidade de o Estado proteger os direitos na forma específica. ${ }^{192}$

Essa categoria sentencial objetiva a tutela específica dos direitos e, justamente por isso, funda-se no princípio da concentração dos poderes do juiz, afastando-se do clássico princípio da tipicidade dos meios executivos ${ }^{193}$. Marinoni e Arenhart sublinham que foi o escopo de tutela específica do direito material que fez com que o poder executivo do juiz fosse amplificado, quebrando-se o princípio da tipicidade dos meios de execução e outorgando-se ao litigante uma forma muito mais complexa e sofisticada de controle das decisões $^{194}$.

A sentença executiva não decorre da estrutura do direito material tutelado, mas sim do sistema de execução em que se insere, o qual confere ao juiz poder para determinar a modalidade executiva necessária à situação de direito substancial e ao caso concreto, visando à tutela na forma específica. Dessa forma, a concentração dos poderes do juiz importa especialmente para a efetividade das tutelas inibitória e de remoção do ilícito e da tutela do direito real, as quais não exigem prestações do demandado. Por outro lado, esse

portanto valem por título executivo. A única diferença é essa eficácia de dispensar a iniciativa da parte para que a execução tenha início. Neste sentido, conclui: "na linguagem jurídica não há lugar para uma sentença executiva, e quem emprega essa expressão está pensando em sentença condenatória. Além disso, por que lato sensu? Qual seria a sentença executiva stricto sensu (Barbosa Moreira)?” (p. 251).

${ }^{191}$ Para Arlete Inês Aurelli, as ações executivas contêm um plus em relação às ações condenatórias, porquanto a produção de efeitos, no mundo empírico, independe de posterior execução. AURELLI, Arlete Inês. As principais alterações..., cit. p. 31.

${ }^{192}$ MARINONI, Luiz Guilherme; ARENHART, Sérgio Cruz. Curso de processo civil, volume 3: execução, cit., p. 117.

${ }^{193}$ MARINONI, Luiz Guilherme; ARENHART, Sérgio Cruz. Curso de processo civil, volume 3: execução, cit., p. 117. A esse respeito, v. item 1.1.3.

${ }^{194}$ MARINONI, Luiz Guilherme; ARENHART, Sérgio Cruz. Curso de processo civil, volume 3: execução, cit., p. 118. A base do novo sistema executivo, e desta forma a inspiração de outra classificação das sentenças, está no direito hegemônico, marcado por situações de direito substancial próprias ao Estado constitucional, as quais não podem ser adequadamente protegidas através da tutela ressarcitória e da técnica da sentença condenatória, mas apenas da tutela específica e das novas sentenças dos arts. 461 e 461-A do código (p. 118). 
mesmo sistema executivo também se aplica às sentenças cujo implemento depende do cumprimento da obrigação contratual ou de ressarcimento do dano na forma específica. ${ }^{195}$

\subsubsection{Sentença mandamental}

As sentenças mandamentais não deixam de ser condenatórias. São dotadas da mesma estrutura lógico-substancial das condenatórias clássicas, compondo-se, portanto, de um momento declaratório e de um momento sancionador. A sentença mandamental é título para execução forçada, diferenciando-se pelo conteúdo da sanção imposta em seu segundo momento, na qual se exacerba o fator comando, ou mandamento. Dinamarco elenca as sentenças que possuem esse teor na legislação brasileira como as concessivas de mandado de segurança e as que condenam por obrigação de fazer, não fazer ou de entregar coisa, tanto no Código de Processo Civil como no Código de Defesa do Consumidor (art. 84). ${ }^{196}$

O caráter mandamental de certas sentenças, que autoriza a execução imediata e coercitiva regida pelos arts. 461 e 461-A, não desfigura essa sua natureza, porque a execução imediata é também uma execução, sendo tais sentenças aptas a propiciar a execução por quantia certa, sempre que a execução se torne impossível ou o credor opte pela conversão em pecúnia. ${ }^{197}$

Para Marinoni e Arenhart, a sentença ligada à execução indireta é mandamental. Nela o juiz utiliza força do Estado para estimular o vencido a adimplir. A sentença condenatória exorta ao pagamento, criando os pressupostos para a execução forçada do direito à soma do dinheiro. Já a sentença mandamental manda que se cumpra, há uma ordem emitida pelo juiz, mediante o emprego de coerção indireta. É correto dizer, nesse sentido, de acordo com os autores, que a sentença que ordena sob pena de multa tem força

\footnotetext{
${ }^{195}$ MARINONI, Luiz Guilherme; ARENHART, Sérgio Cruz. Curso de processo civil, volume 3: execução, cit., p. 118. Por fim, resumem os autores: "de acordo com o art. 475-N, a obrigação de pagar quantia é tutelada mediante sentença condenatória, mas as obrigações de não fazer, fazer e entregar coisa podem ser tuteladas mediante sentença mandamental ou sentença executiva. A sentença condenatória apenas tutela obrigação de pagar, enquanto as sentenças mandamental e executiva podem tutelar somente obrigações de não fazer, fazer ou entregar coisa." (p. 118).

${ }^{196}$ DINAMARCO, Cândido Rangel. Instituições..., vol. III, cit., p. 248.

${ }^{197}$ DINAMARCO, Cândido Rangel. Instituições..., vol. IV, cit., p. 256.
} 
mandamental, enquanto a sentença condenatória não tem força alguma, nem mesmo executiva: sua eficácia é que é executiva. ${ }^{198}$

Nas ações mandamentais o juiz não se limita a dizer o direito, aplicando, para o cumprimento da sentença, medidas sub-rogatórias da vontade do obrigado, que havia se recusado a cumprir a obrigação. O juiz faz mais do que isso, ele determina a prática de ato que somente o réu poderia cumprir e mais ninguém. $\mathrm{O}$ réu fica sujeito à estatalidade do juiz, não podendo se recusar a obedecer, sob pena de sanções disciplinares e penais. O que caracteriza a sentença como mandamental é o fato de que, independentemente de processo de execução, a ordem dela emanada será realizada coercitivamente no plano empírico, sem que se possa oferecer qualquer resistência. ${ }^{199}$

Bedaque, por sua vez, sustenta que a especificidade dessa modalidade de tutela jurisdicional está exclusivamente na vontade do legislador. Situação material que hoje comporta tutela monitória ou condenatória, amanhã poderá ser passível de tutela mandamental, como ocorreu, segundo o autor, com as obrigações de fazer, não fazer e dar, que até 1994 e 2002 admitiam mera tutela condenatória. Para Bedaque, o traço distintivo dessa espécie de sentença é que a técnica destinada a efetivá-la não é a prática de atos materiais de sub-rogação, valendo-se o legislador de outros meios, que são a ordem acompanhada de medidas destinadas a fazer com que o destinatário a obedeça. ${ }^{200}$

Assim, corroborando com lição de Botelho de Mesquita, Bedaque sustenta que a mandamentalidade não está na natureza da sentença, mas na forma de efetivá-la. Pois, quer se entenda a mandamentalidade como forma de efetivar apenas as sentenças condenatórias, quer se estenda a ordem também às constitutivas e declaratórias, o que fica muito claro segundo o autor é a inaptidão dessa característica, ligada à forma de efetivação da tutela

\footnotetext{
${ }^{198}$ MARINONI, Luiz Guilherme; ARENHART, Sérgio Cruz. Curso de processo civil, volume 3: execução, cit., p. 116.

${ }^{199}$ AURELLI, Arlete Inês. As principais..., cit., p. 32/33. De acordo com a autora, é justamente essa característica, esse elemento eficacial, que é aferida no plano empírico, qual seja, possibilitar a concessão in natura do pedido, que diferencia a ação mandamental das outras e, principalmente, da executiva lato sensu ou até mesmo das ações constitutivas. De fato, tendo em vista que a característica básica das ações executivas lato sensu é possibilitar a execução do julgado por meio de um único ato, o que ocorre com o próprio trânsito em julgado da decisão, sem necessitar de um processo de execução para tanto, tal como ocorre na ação mandamental, que é executada através de um simples ofício, não fosse pela característica acima, ficaria difícil diferenciar ambas as ações (p. 33).

${ }^{200}$ BEDAQUE, José Roberto dos Santos. Efetividade do processo e técnica processual, cit., p. 515. O autor afirma que tal corrente é liderada por Barbosa Moreira.
} 
jurisdicional, para conferir autonomia às sentenças mandamentais, como categoria autônoma. $^{201}$

\subsubsection{Coisa julgada}

A Constituição Federal, em seu artigo $5^{\circ}$, inciso XXXVI, prevê como um dos direitos fundamentais que a lei não prejudicará a coisa julgada (auctoritas rei judicatae) e o Código de Processo Civil, por sua vez, determina ao juiz que se abstenha de decidir a mesma causa, extinguindo o processo sem julgamento do mérito, quanto existir a coisa julgada material (art. 267, inc. V e $\S 3^{\circ}$ ). A coisa julgada está regulamentada nos artigos 467 a 475 do Código.

Coisa julgada, em direito processual, é imutabilidade. Quando proferida, a sentença de mérito e os seus efeitos ainda são mera proposta de solução do litígio, ou simplesmente proposta de solução do litígio (sentenças terminativas), já que ainda possível a substituição da sentença e alteração do julgamento após interposição de recurso. Nesse sentido, uma decisão judicial só fica imune a qualquer questionamento futuro quando já não comporta recurso, ainda que em alguma medida a lei libere para produzir seus efeitos, ou alguns deles, antes que isso aconteça. ${ }^{202}$

O Código de Processo Civil prevê no artigo 467 o conceito de coisa julgada material como sendo a eficácia que torna imutável e indiscutível a sentença, não mais sujeita a recurso ordinário ou extraordinário. ${ }^{203}$ Quando a sentença é de mérito, projeta efeitos para fora do processo e sobre a vida das pessoas, para além do fenômeno puramente processual da sentença terminativa, de forma a preservar os seus efeitos, de modo que o julgamento daquela pretensão, entre aquelas pessoas e por aquele fundamento fique perenemente imunizado e assim se implante uma situação de segurança quanto aos direitos, obrigações e deveres dos litigantes. ${ }^{204}$

\footnotetext{
${ }^{201}$ BEDAQUE, José Roberto dos Santos. Efetividade do processo e técnica processual, cit., p. 515.

${ }^{202}$ DINAMARCO, Cândido Rangel. Instituições..., vol. III, cit., p. 293.

${ }^{203}$ DINAMARCO em sua obra defende que seria melhor não falar em eficácia: "Qual ato seria produtor essa eficácia? A própria sentença, não. Nem algum outro ato, do juiz ou de quem quer que fosse, capaz de conferir-lhe imutabilidade. E, mais precisamente, a coisa julgada material incide sobre os efeitos da sentença, não sobre ela própria como ato jurídico-processual - a proteção desta é feita pela coisa julgada formal" (ob. cit., p. 302).

${ }^{204}$ Francesco Carnelutti acerca da eficácia, autoridade e imutabilidade da sentença, discorre: "Il valore o il peso di una sentenza è precisamente ciò che noi chiamiamo la sua efficacia, cioè la misura del suo valere di
} 
Essa estabilidade e imunização, quando encarada em sentido bastante amplo, atinge, conforme o caso, somente a sentença como ato processual ou ela própria e também os seus efeitos. ${ }^{205} 206207$

$\mathrm{O}$ art. 469, para definir o que faz coisa julgada, serviu-se de uma fórmula negativa, dizendo o que não faz coisa julgada, tornando-se imutáveis e indiscutíveis o elemento declaratório, a manifestação de vontade - sentença de procedência - e o juízo de rejeição do pedido - sentenças de improcedência.

Assim, coisa julgada formal é a imutabilidade da sentença como ato jurídico processual. Nas palavras de Mesquita, é a indiscutibilidade e imutabilidade de uma decisão dentro do próprio processo em que foi proferida (art. 473). ${ }^{208}$ Consiste no impedimento de qualquer recurso ou expediente processual destinado a impugná-la, de modo que, naquele processo, nenhum outro julgamento se fará. Tem uma feição e uma missão puramente técnico-processuais, sendo que toda e qualquer sentença é apta a receber

fronte ad alcuno. Più frutuosa ancora sarebbe riescita l'indagine del significato delle parole $<<$ secondo la connessione di esse >>. Nella sistassi degli art. 1350 e 1351 l'autorità non è la cosa giudicata ma un atributo della cosa giudicata $(<<$ l'autorità che la legge attribuisce alla cosa giudicata $>>$; $<<$ l'autorità della cosa giudicata>>); ciò vuol dire che per cosa giudicata la legge non intende altro che la sentenza, alla quale appunto riconosce ciò che essa chiama una autorità; ma questa autorità deve dunque esse ciò che dalla sentenza emana, ciò̀ la sua efficacia. Con una metatesi noi chiamiamo cosa giudicata anzichè la sentenza, codesta efficacia medesima; così la cosa giudicata invece del soggeto (sentenza) diventa il predicato (autorittà della sentenza); ma allora cosa giudicata cioè autorità della sentenza non è altro che quel modo di essere che la legge le attribuisce, ciò̀ il suo valere pro veritate o meglio il suo valere come legge" (Studi di Diritto Processuale, volume terzo, Padova, Cedam Casa Editrice Dott. Antonio Milani, 1939, p. 64).

${ }^{205}$ DINAMARCO, Cândido Rangel. Instituições..., vol. III, cit., p. 294. O autor afirma que a função da coisa julgada tout court é a de proporcionar segurança nas relações jurídicas, sabendo-se que a insegurança é gravíssimo fator perverso que prejudica os negócios, o crédito, as relações familiares e, por isso, a felicidade pessoal das pessoas ou grupos. O instituto na língua alemã (Rechtskraft) significa força de lei.

${ }^{206}$ De acordo com José Ignácio Botelho de Mesquita, trânsito em julgado é o fato de não estar mais a sentença sujeita a recursos ordinários ou extraordinários. Efeitos do trânsito em julgado são a indiscutibilidade e a imutabilidade da conclusão da sentença, nos termos do art. 467 do CPC. O elemento declaratório e a manifestação de vontade a que se vincula o efeito pretendido pelo autor ou o juízo de improcedência da ação que se tornam imutáveis e indiscutíveis (BOTELHO DE MESQUITA, José Ignacio, cit., p. 11).

207 São qualidades que a lei atribui à conclusão da sentença, como consequiência do fato do trânsito em julgado, não importando qual seja o conteúdo do seu elemento declaratório. A esse efeito se denomina coisa julgada material. Na imutabilidade, passa a ser proibida a proposição de uma ação idêntica a outra já decidida por sentença revestida da autoridade da coisa julgada. Já a indiscutibilidade opera em relação a quaisquer processos em que a decisão do pedido do autor dependa do julgamento de questão prévia que tenha sido decidida por via principal em processo anterior, entre as mesmas partes. Ao contrário da imutabilidade, a indiscutibilidade pressupõe que sejam distintas as ações que são objeto de cada um dos processos (p. 10/11).

${ }^{208}$ BOTELHO DE MESQUITA, José Ignacio, cit., p. 12. 
a coisa julgada formal. ${ }^{209}$ Vários são os momentos em que concretamente as sentenças passam em julgado, seja porque variam os fatores responsáveis pela preclusão e as técnicas dos recursos, seja porque no dia-a-dia do processo ocorrem situações distintas, as quais interferem na irrecorribilidade. ${ }^{210}$

De outra parte, coisa julgada material é a imutabilidade dos efeitos substanciais da sentença de mérito. Quer se trate de sentença meramente declaratória, constitutiva ou condenatória, ou mesmo quando a demanda é julgada improcedente, no momento em que já não couber recurso algum, segundo Dinamarco, institui-se entre as partes e em relação ao litígio que foi julgado, uma situação de absoluta firmeza quanto aos direitos e obrigações que os envolvem. Essa situação, que transcende a vida do processo e atinge a das pessoas, consiste na rigorosa intangibilidade das situações jurídicas criadas ou declaradas, de modo que nada poderá ser feito por elas próprias, nem por outro juiz, nem pelo próprio legislador, que venha a contrariar o que foi decidido. 211212213

Diante disso, a coisa julgada material não é instituto restrito ao direito processual, tendo acima de tudo significado político-institucional de assegurar a firmeza das situações jurídicas, tanto que prevista entre as garantias constitucionais. Neste sentido, as normas e técnicas do processo limitam-se a reger os modos como a coisa julgada se produz e os instrumentos pelos quais é protegida a estabilidade dessas relações, mas a coisa julgada

\footnotetext{
${ }^{209}$ DINAMARCO, Cândido Rangel. Instituições..., vol. III, cit., p. 295. Fala-se somente em sentença por mera comodidade de linguagem, pois a coisa julgada formal atinge também os acórdãos dos tribunais, sempre que determinem a extinção do processo, com ou sem julgamento do mérito. $\mathrm{O}$ acordão com essa eficácia equivale a uma sentença, em sentido amplo.

${ }^{210}$ DINAMARCO, Cândido Rangel. Instituições..., vol. III, cit., p. 296/7. A perda do direito aos recursos é fruto de um desses três fatores preclusivos: a) decurso do tempo, preclusão temporal, b) prática de ato incompatível com a vontade de recorrer, preclusão lógica; c) interposição do próprio recurso, preclusão consumativa.

${ }^{211}$ DINAMARCO, Cândido Rangel. Instituições..., vol. III, cit., p. 299/300. A garantia constitucional da coisa julgada consiste, assim, na imunização geral dos efeitos da sentença.

${ }^{212}$ Tratando-se de direitos disponíveis, contudo, é lícito às partes, por mútuo consentimento, ajustar direitos e obrigações de modo diferente do julgado, de acordo com a chamada eficácia rebus sic stantibus da coisa julgada material. (DINAMARCO, Cândido Rangel. Instituições..., vol. III, cit., p. 300).

${ }^{213}$ A esse respeito, Mesquita leciona que, salvo as exceções previstas em lei, a imutabilidade e a indiscutibilidade da sentença só operam em relação às partes perante as quais a sentença foi dada, não beneficiando nem prejudicando terceiros, conforme art. 472 CPC. Assim, a imutabilidade impede que o juiz posterior se pronuncie sobre a ação já decidida por sentença transitada em julgado. Cria a exceção de coisa julgada. A indiscutibilidade obriga o juiz posterior a decidir em conformidade com o decidido pela sentença transitada em julgado (BOTELHO DE MESQUITA, José Ignacio, cit., p. 12).
} 
material é um instituto de direito processual material, não confinado às técnicas e estruturas do processo. ${ }^{214}$

A esse respeito, o eminente processualista Enrico Tullio Liebman afirmava que considerar a coisa julgada como efeito da sentença e ao mesmo tempo admitir que a sentença ora produz simples declaração, ora efeito constitutivo, assim de direito substantivo, como de direito processual, significa colocar frente a frente elementos inconciliáveis, grandezas incongruentes e entre si incomensuráveis. Para o autor, a autoridade da coisa julgada não é o efeito da sentença, mas uma qualidade - a imutabilidade - de que podem revestir os seus efeitos (ou melhor, todos os seus efeitos), um modo de ser e de manifestar-se dos seus efeitos, quaisquer que sejam, vários e diversos, consoante as diferentes categorias de sentenças. ${ }^{215} 216$

Acerca da tese de Liebman e a distinção entre a eficácia da sentença e a autoridade de seus efeitos, Dinamarco a aponta como uma das mais elegantes conquistas da ciência processual no século das luzes processuais, sendo que a consciência de que se trata de dois fenômenos distintos é a chave para a solução de muitos problemas teóricos e práticos relacionados com o instituto. ${ }^{217}$

214 DINAMARCO, Cândido Rangel. Instituições..., vol. III, cit., p. 301. De acordo com o autor, o mais significativo efeito processual da coisa julgada material é a extinção do direito de ação. Na medida em que impede novo julgamento do mérito, ela exclui o direito do autor de obtê-lo. E segue: "Essa foi no passado uma das mais importantes afirmações ligadas à identificação da natureza processual da coisa julgada (Ugo Rocco). Disse-se também que ela se resolve em uma presunção de verdade (Pothier), ou em uma ficção de verdade (Savigny). Foi também afirmado que a coisa julgada material seria o direito do vencedor a obter dos órgãos jurisdicionais a observância do que tiver sido julgado (Hellwig)" (ob. cit., p. 301).

215 LIEBMAN, Enrico Tullio. Eficácia e autoridade da sentença e outros escritos sobre a coisa julgada. Trad. Alfredo Buzaid e Benvindo Aires, Rio de Janeiro, Revista Forende,1945, passim. Prossegue o autor: "A análise de várias figuras de sentenças (constitutiva, declaratória, condenatória) demonstrou precisamente a variedade dos seus possíveis efeitos. Têm algumas efeito meramente declaratório, outras têm também efeito constitutivo, outras produzem o efeito sancionador que se expressa pela palavra condenação."

216 Por sua vez, Botelho de Mesquita defende que a autoridade da coisa julgada consiste na indiscutibilidade do elemento declaratório da sentença transitada em julgado. A hipótese de simples reiteração de ação idêntica a outra já decidida por sentença transitada em julgado é extremamente remota e só se poderia atribuir à ignorância ou má-fé. No que respeita à indiscutibilidade, o efeito do trânsito da sentença difere do efeito declaratório da sentença (transitada em julgado ou não), sob três aspectos. O primeiro deles é que o efeito declaratório é um efeito da sentença, enquanto que a indiscutibilidade do elemento declaratório da sentença transitada em julgado é um efeito do fato em si do trânsito em julgado. O elemento declaratório só se torna vinculante após o trânsito em julgado. O segundo aspecto é que, exatamente por isso, o efeito declaratório pode se produzir antes mesmo que surja o vínculo decorrente do trânsito da sentença. A declaração pode se tornar vinculante antes mesmo que a sentença se torne imutável e indiscutível. Finalmente, o terceiro aspecto é que a indiscutibilidade decorrente do trânsito em julgado opera somente entre as partes, enquanto que o efeito declaratório vincula tanto as partes como terceiros (BOTELHO DE MESQUITA, José Ignacio, cit., p. 13/14).

${ }^{217}$ DINAMARCO, Cândido Rangel. Instituições..., vol. III, cit., p. 302. 
Por outro lado, o artigo 472 do Código de Processo Civil preconiza que a sentença faz coisa julgada às partes entre as quais é dada, não beneficiando, nem prejudicando terceiros. Nas causas relativas ao estado de pessoa, se houverem sido citados no processo, em litisconsórcio necessário, todos os interessados, a sentença produz coisa julgada em relação a terceiros. A exegese deste dispositivo poderia levar à impossibilidade de produção de coisa julgada na ação coletiva, pois somente àqueles que estivessem presentes no processo a sentença poderia produzir efeitos.

Neste sentido, Liebman cinde o problema dos limites subjetivos da coisa julgada em duas questões diversas e distintas: a da eficácia da sentença em relação a terceiros e a da coisa julgada em relação a terceiros, afirmando que apesar de haver posição firme na doutrina de estender a terceiros ou a certos terceiros a autoridade da coisa julgada sob a espécie de uma eficácia reflexa, a coisa julgada, assim como não é para as partes um efeito da sentença, não pode sê-lo para os terceiros, nem por via direta nem por via reflexa ${ }^{218}$. Todo o efeito que a sentença produzir, tomado em si separadamente, permanece o único e sempre o mesmo, qualquer que seja o número de pessoas que lhes sofram as consequências. $^{219}$

218 LIEBMAN, Enrico Tullio. Eficácia..., cit. p. 72/75.

219 LIEBMAN, Enrico Tullio. Eficácia..., cit. p. 78. Botelho de Mesquita, por sua vez, ao tratar do tema cita o famoso caso da ação declaratória de nulidade de uma deliberação de assembleia geral da sociedade anônima. Julgada procedente a ação proposta por um dos acionistas, afirma que o efeito da declaração de nulidade operará em relação a todos os demais acionistas, tanto os que tenham interesse convergente como os que tenham interesse contrário ao do acionista autor. $\mathrm{O}$ efeito da declaração beneficiará aqueles e prejudicará estes que ficarão impedidos de formular qualquer pretensão jurídica fundada na deliberação declarada nula. Ao contrário, julgada improcedente a ação do exemplo citado, a conclusão da sentença -a deliberação não padece de causa de nulidade arguida pelo autor- se tornará imutável e indiscutível entre as partes (autor e sociedade), mas não será oponível a nenhum dos demais acionistas que tenham interesse na declaração de nulidade. Qualquer deles ficará livre para propor a ação, com o mesmo objeto e idêntico fundamento, e, se a ação for julgada procedente, o efeito da declaração de nulidade beneficiará todos os acionistas que nela tenham interesse, inclusive o que propôs a ação julgada improcedente.

Nesse sentido, para o autor é incorreta a afirmação de que todas as sentenças, inclusive as de improcedência, produzem efeito declaratório e que, após o trânsito em julgado, esses efeitos se tornam imutáveis e indiscutíveis entre as partes, não beneficiando, nem prejudicando, terceiros. Prossegue o processualista afirmando que se isto fosse verdadeiro, teríamos no exemplo dado uma hipótese de conflito entre efeitos declaratórios imutáveis e indiscutíveis; um para cada sócio em sentidos contrários, gerando para a companhia uma situação de perplexidade insuperável. Na medida em que se tentasse resolver esse conflito fazendo prevalecer a sentença de procedência declaratória da nulidade sobre a sentença de improcedência, estar-se-ia admitindo que os efeitos daquela mudassem os efeitos desta, que já não seriam mais imutáveis nem indiscutíveis, a despeito da autoridade da coisa julgada.

Admitindo-se, continua Mesquita, que a sentença de improcedência não produz efeito nenhum, isto é, não produz nenhuma alteração no plano das relações jurídicas entre as partes, ou entre elas e terceiros, limitandose a uma recusa à produção do efeito pretendido, o panorama se altera completamente. A mera recusa à produção de qualquer alteração no estado de direito o deixa na mesma situação que existia antes da propositura da ação e em nada modifica quer a relação das partes entre si quer a relação de qualquer delas 
A limitação subjetiva da coisa julgada às partes e a seus sucessores é uma coisa. Mas ela não exclui a extensão subjetiva da eficácia da sentença aos terceiros. Todos estão sujeitos à eficácia natural da sentença, mas enquanto para as partes os efeitos da sentença se tornam imutáveis quando ela transita em julgado, isso não ocorre com os terceiros. Estes podem insurgir-se contra a eficácia natural da sentença, mediante os remédios processuais próprios, porquanto não são atingidos pela coisa julgada, vista como imutabilidade dos efeitos da sentença.

No mesmo sentido, Ada Pellegrini Grinover afirma que a imutabilidade da sentença e dos seus efeitos, assim restrita à coisa julgada e limitada às partes no processo, não impede, desse modo, que os terceiros se oponham à eficácia natural da sentença, que para eles existe mas pode ser removida pelos instrumentos processuais adequados. ${ }^{220}$

No caso de sentença meramente declaratória -inclusive em caso de improcedência da demanda inicial- a coisa julgada incide sobre a declaração positiva ou negativa contida nessa sentença. Se é condenatória, incide sobre os dois momentos lógico-substanciais desta, imunizando a declaração de existência do direito e a formação de título para a execução forçada. Se é constitutiva, ficam cobertas pela autoridade do julgado a declaração de existência do direito à modificação jurídica e a implantação da nova situação jurídica a que o autor tinha direito. ${ }^{221}$

com terceiros. Continua, pois, a situação jurídica em condições de ser alterada pelos efeitos de futura sentença, exatamente como era antes da propositura frustrada da primeira ação. Não há colisão de efeitos jurídicos antagônicos.

Além disto, assentado que, diversamente da imutabilidade e indiscutibilidade de elemento declaratório, os efeitos declaratórios se produzem erga omnes, torna-se explicável o motivo pelo qual a segunda sentença pode beneficiar ou prejudicar terceiros enquanto que a primeira não. Esse modo de compreender a autoridade da coisa julgada e a eficácia da sentença é mais claramente perceptível em relação às sentenças que julgam ações condenatórias ou ações constitutivas, apesar de atuarem exatamente da mesma maneira em relação às declaratórias.

Por fim, Mesquita coloca em discussão a existência de possível conflito, no caso exemplificado, entre vínculos impostos ao juiz (um decorrente da autoridade da primeira sentença e outro gerado pela eficácia da segunda). A resposta do autor é pela negativa. O novo juiz está vinculando ao elemento declaratório da sentença procedente dada entre as mesmas partes apenas enquanto se mantiver inalterada entre elas a situação que deu causa àquela sentença. Alterada essa situação por força de ato jurídico posterior (negócio jurídico, ato administrativo ou sentença), qualquer novo litígio entre as mesmas partes já se baseará na nova situação substancial e terá que ser decidido em conformidade com ela. A sentença, como diz o CPC, só tem força de lei nos limites da lide e das questões decididas (art. 468) (BOTELHO DE MESQUITA, José Ignacio, cit., p. 14/17).

220 GRINOVER, Ada Pellegrini. Eficácia e autoridade da sentença: a teoria de Liebman no Código de Defesa do Consumidor e no Código Modelo de Processos Coletivos para Ibero-América. p. 203.

${ }^{221}$ DINAMARCO, Cândido Rangel. Instituições..., vol. III, cit., p. 303. 
Quanto aos limites objetivos da coisa julgada material, somente o preceito concreto contido na parte dispositiva das sentenças de mérito fica protegido pela autoridade da coisa julgada material, não os fundamentos em que ele se apoia (art. 469, CPC) ${ }^{222}$. De acordo com a doutrina de Dinamarco, tal previsão é inerente à própria natureza do instituto e à sua finalidade de evitar conflitos práticos de julgados, capazes de criar incertezas na vida comum das pessoas. ${ }^{223}$

Contudo, aquilo que foi decidido, que tenha conteúdo decisório, transita em julgado, estando no dispositivo ou na fundamentação da sentença. Isto é, deve-se compreender que o que passa em julgado não compreende apenas a frase final da sentença, mas também tudo quanto o juiz porventura haja considerado e resolvido acerca do pedido feito pelas partes. ${ }^{224}$

O legislador, além disso, prevê no art. 474 a eficácia preclusiva da coisa julgada, de forma que passada em julgado a sentença de mérito, reputar-se-ão deduzidas e repelidas todas as alegações e defesas, que a parte poderia opor assim ao acolhimento como à rejeição do pedido. Alguns doutrinadores entendem que o dispositivo não impede a reformulação do mesmo pedido, desde que com base em outra causa de pedir, ainda que se trate de causa de pedir que poderia ter sido alegada na primeira ação, mas não o foi. Por outro lado, há autores que entendem que a extensão da eficácia preclusiva da coisa julgada abrange todas as possíveis causas de pedir que pudessem ter embasado o pedido formulado. A coisa julgada implicaria, assim, o julgamento de todas as causas de pedir que pudessem ter sido deduzidas, mas não foram. ${ }^{225}$

\footnotetext{
${ }^{222}$ Art. 469. Não fazem coisa julgada:

I - os motivos, ainda que importantes para determinar o alcance da parte dispositiva da sentença;

Il - a verdade dos fatos, estabelecida como fundamento da sentença;

III - a apreciação da questão prejudicial, decidida incidentemente no processo.

${ }^{223}$ DINAMARCO, Cândido Rangel. Instituições..., vol. III, cit., p. 311/312. Segundo o autor, a lei quis afastar a tese de Savigny, segundo a qual os motivos fundamentais tornar-se-iam imutáveis quando chega a coisa julgada material. O autor ainda ressalta a importância de distinguir os conceitos de lide e questão, de conhecida doutrina que o Código acolhe e a Exposiçaõ de Motivos aplaude (Carnelutti). Lide, na linguagem do CPC, é o mérito, ou seja, o conflito entre pretensões posto diante do juiz para que um dos litigantes receba as vantagens da tutela jurisdicional e o outro seja legitimamente sacrificado. Questões são pontos duvidosos de fato ou de direito. Para decidir a lide, ou mérito - o que é feito na parte dispositiva da sentença - o juiz previamente posiciona-se quanto àquelas dúvidas, ou questões, fazendo-o na motivação (ob. cit., p. 226).

${ }^{224}$ NEVES, Celso, Estrutura fundamental do processo civil, cit., p. 241. O autor cita expressamente a doutrina de Liebman neste sentido.

${ }^{225}$ DIDIER JR, Fredie. Extensão da eficácia preclusiva da coisa julgada. Art. 474 do CPC, o art. 495 do NCPC e o art. 98, $\S 4^{o}$, da Lei 12.529/2011. Editorial 132 de 13/12/2011, disponível em
} 
A esse respeito, Fredie Didier Jr. afirma que a Lei 12.529/2011, ao reorganizar a estrutura administrativa de proteção da concorrência no Brasil, adotou a segunda posição, ao prever no $\S 4^{\circ}$ no art. 98 que nos processos em que se discute ato do CADE o autor deverá deduzir todas as questões de fato e de direito, sob pena de preclusão consumativa, reputando-se deduzidas todas as alegações que poderia deduzir em favor do acolhimento do pedido, não podendo o mesmo pedido ser deduzido sob diferentes causas de pedir em ações distintas, salvo em relação a fatos supervenientes. ${ }^{226}$ Tal inovação poderá ser levada em conta para interpretação do instituto e para o processo legislativo do novo Código.

Por fim, frise-se que, em princípio, os efeitos da sentença são mutáveis, não diferindo muito dos efeitos dos atos jurídicos em geral. ${ }^{227}$ De outra parte, os direitos criados pela sentença estarão sempre sujeitos às vicissitudes por que passaram os direitos em geral. Podem extinguir-se, pode perecer o seu objeto (art. 77 do CC) ou podem ficar encobertos, no caso de prescrição. Há casos em que, excepcionalmente, se admite a modificação dos efeitos de uma sentença por outra. Por serem excepcionais têm que estar expressamente previstos em lei (art. 471, incisos I e II). Essas ações têm por objeto a modificação ou a desconstituição dos efeitos da sentença, como por exemplo as ações revisional de alimentos e de restabelecimento de sociedade conjugal dissolvida pela separação judicial. A ação rescisória não entra aqui, pois tem por fundamento a existência de um vício na sentença, que a destrói e, com ela, os seus efeitos. ${ }^{228}$

\footnotetext{
<http://www.frediedidier.com.br/main/noticias/impressao.jsp?CId=477>, acesso em 7/1/2012. A esse respeito, Didier cita como favoráveis da primeira corrente Barbosa Moreira, Moniz de Aragão e Daniel Mitidiero e como contrário Araken de Assis. Além disso, cita que a primeira posição sempre foi havida como majoritária, em níveis doutrinários e jurisprudenciais, tendo sido inclusive adotada no projeto de lei do novo Código de Processo Civil (art. 495).

${ }^{226}$ DIDIER JR, Fredie. Extensão da eficácia preclusiva da coisa julgada, cit.

${ }^{227}$ Enquanto não transitada em julgado, os seus efeitos podem ser extintos ou modificados por outra decisão em graus de recurso, ou mediante ato ou negócio jurídico entre as partes. Após o trânsito em julgado, os seus efeitos só se poderão extinguir ou modificar por atos jurídicos das próprias partes e não mais por sentença. Essa impossibilidade de modificação dos efeitos da sentença em processo posterior decorre do fato de que o novo processo em que se pretendesse a alteração teria que ter por objeto uma ação idêntica à já decidida por sentença transitada em julgado, o que é vedado pelo art. 301, inciso VI do CPC. As partes, porém, podem modificar os efeitos da sentença transitada em julgado, bastando que eles incidam sobre direitos disponíveis.

${ }^{228}$ BOTELHO DE MESQUITA, José Ignacio, cit., p. 18/19. Por fim, Botelho de Mesquita explica que sua teoria de eficácia da sentença e autoridade da coisa julgada, aqui colocada, mergulha suas raízes nas noções expostas por Liebman, se aproximando em certos aspectos desenvolvidos, bem antes, por Hellwig, notadamente na diferenciação entre elemento e efeito declaratório. Argumenta que a teoria de Barbosa Moreira é a mais próxima da sua no Brasil, apesar de não ter adotado a ruptura entre elemento e efeito declaratório.
} 


\section{EXECUÇÃO E CUMPRIMENTO DA SENTENÇA}

Feito o estudo da tutela jurisdicional, em especial da sentença judicial que resolve o mérito do processo, passa a ser relevante a análise da efetivação no mundo real daquilo que foi reconhecido pelo juiz. Caso o obrigado não cumpra espontaneamente sua obrigação, surge a necessidade da execução do julgado.

Atendo-se aos limites do presente estudo e, evidentemente, não pretendendo esgotar o assunto, mister analisar alguns institutos fundamentais da execução e do cumprimento da sentença.

\subsection{A satisfação do direito}

Dá-se o nome de execução àquelas operações que, em decorrência da natureza do provimento reclamado e obtido pelo vitorioso, destinam-se a entregar-lhe o bem da vida. A certeza e o estado jurídico novo que decorrem da própria resolução do juiz não resultam nos demais efeitos, que precisam ser arrancados do mundo dos fatos. Ela se realiza no mundo real. ${ }^{229}$

Tal atividade se desenvolve perante o órgão judiciário e, embora seus resultados não sejam imunes a posteriores controvérsias, a execução assume inequívoca natureza jurisdicional. Desde que provocado pela iniciativa do vitorioso, o órgão judiciário realiza os direitos no âmbito de uma relação processual, formada através do direito à tutela jurídica do Estado, o que evidencia a natureza jurisdicional da execução. ${ }^{230}$

A rígida tripartição das funções em cognição, execução e cautelar, como estruturas autônomas e separadas, não é verdadeira. Em todo processo, ainda que sua função principal seja a de executar ou a de assegurar, haverá cognição, sem a qual o órgão judiciário jamais atingiria seus objetivos.

Araken de Assis, a esse respeito, enfatiza que o Livro II do CPC claramente se estruturou sob a influência da doutrina de Enrico Tulio Liebman, especialmente em relação

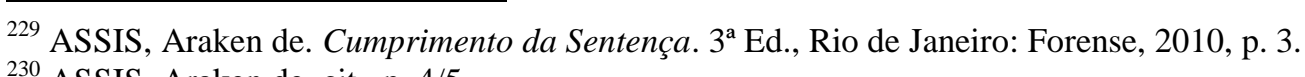

${ }^{230}$ ASSIS, Araken de, cit., p. 4/5. 
à unificação das vias executivas, em contraposição ao sistema do Código de 1939, que previa a execução de sentença (ação executória) e a ação executiva. ${ }^{231}$ O CPC de 1973, de Alfredo Buzaid, adotou a política da unificação das vias executivas.

Quando se pensa na tutela jurisdicional como resultado em prol do vencedor, o provimento de natureza condenatória é, de fato, insuficiente para proporcionar ao credor o bem da vida por ele pretendido e como tal reconhecido em provimento jurisdicional. De fato, excetuada a hipótese de cumprimento voluntário do comando judicial - e a multa de $10 \%$ prevista no art. 475-J do CPC tem se mostrado mais efetiva nesse convencimento - a tutela positiva-se através do binômio condenação/execução. Daí falar-se em tutela condenatória/executiva. $^{232}$

O processo executivo produz sempre o mesmo resultado, que é a satisfação do credor. Nunca se produzirão efeitos substanciais de satisfação do devedor, a menos que a execução seja obstada por algum contratempo capaz de impedi-la de chegar a bom termo (art. 794, inc. III, etc). ${ }^{233} 234$

Quanto aos resultados proporcionados na tutela executiva - entrega do bem da vida ao credor - relembre-se as considerações acerca da sentença condenatória, uma vez que a imposição da prestação já foi fixada, devendo a execução manter-se fiel ao conteúdo do título executivo. Tais resultados, portanto, devem ajustar-se ao modelo referido no título que, sob essa ótica, também apresenta algum contorno de tipicidade. ${ }^{235}$

Os meios executivos, a esse respeito, variam segundo a natureza do direito a ser satisfeito, isto é, do resultado a ser proporcionado ao credor, sendo predispostos de forma diversa se for o caso de entrega de quantia ou de coisa, ou ainda a imposição e/ou

\footnotetext{
${ }^{231}$ ASSIS, Araken de. ob. cit, p. 148.

${ }^{232}$ YARSHELL, Flavio Luiz. Tutela..., cit., p. 255/256.

${ }^{233}$ DINAMARCO, Cândido Rangel. Instituições..., vol. III, cit., p. 200.

${ }^{234}$ De acordo com Yarshell, na execução a tutela jurisdicional - se entendida no sentido de resultado em prol de quem ostenta um direito - opera-se exclusivamente para o exequente. Qualquer forma de tutela para o executado deve dar-se através da tutela cognitiva, de natureza meramente declaratória ou, eventualmente, constitutiva negativa, através da ação de embargos do devedor. Assim, a tutela executiva descende da garantia geral da ação e da inafastabilidade, tanto mais porque a atuação executiva dos direitos reconhecidos em pronunciamentos judiciais é fator de afirmação do próprio poder estatal, sendo impensável que a condenação pudesse vir desacompanhada dos meios de efetivá-la (YARSHELL, Flavio Luiz. Tutela .., cit., p. 256).

${ }^{235}$ YARSHELL, Flavio Luiz. Tutela..., cit., p. 257.
} 
efetivação de um fazer ou um não fazer. E mesmo em cada uma dessas modalidades de obrigações há variações ditadas por particularidades extraídas da relação material. ${ }^{236}$

Assim, em suma vigora uma regra de tipicidade no estabelecimento dos meios executivos, porque a lei estabelece um modelo para tanto, mas essa regra pode ser relativizada em algumas hipóteses, quer pela diversidade dos meios, quer pela amplitude de poderes conferidos ao juiz para compelir o devedor ao adimplemento. ${ }^{237}$

\subsection{Sistema executivo}

No direito romano clássico, conforme lição de Marinoni e Arenhart, uma vez proferida a sentença condenatória, era necessário aguardar trinta dias pelo cumprimento da sentença, prazo após o qual o autor, para executar a condenação, deveria propor nova ação, chamada de actio iudicati. Diante dessa nova ação, o réu poderia reconhecer a condenação e o inadimplemento, ou apresentar defesa. Nesse último caso, o credor pedia que o réu fosse condenado a pagar o dobro do valor objeto da condenação. ${ }^{238}$

Durante toda a longa história de Roma, contudo, ao lado da separação rigorosa das áreas de aplicação da actio e da actio iudicati, sempre houve remédios processuais que, em casos especiais ditados pela natureza do direito em jogo e pela premência de medidas urgentes, permitiam decisões e providências executivas aplicadas de imediato pelo pretor. $^{239}$

\footnotetext{
${ }^{236}$ YARSHELL, Flavio Luiz. Tutela..., cit., p. 258. O autor cita o caso da execução por quantia certa contra a Fazenda Pública, a execução da prestação alimentícia e o rol atípico de medidas que o juiz pode se utilizar para compelir o devedor a realizar a prestação devida ao credor, conforme $\S 5^{\circ}$ do art. 461 do CPC.

${ }^{237}$ YARSHELL, Flavio Luiz. Tutela..., cit., p. 259.

${ }^{238}$ MARINONI, Luiz Guilherme; ARENHART, Sérgio Cruz. Curso de processo civil, volume 3: execução, cit., p. 27. Humberto Theodoro Junior leciona sobre a história da execução forçada no direito antigo de origem românica, afirmando que na origem só se chegava à prestação jurisdicional executiva depois de acertado o direito do credor por meio de sentença. Esta autorizava a intromissão do credor no patrimônio do devedor, mas isto reclamava o exercício de uma nova ação, a actio iudicati. O exercício do direito de ação fazia-se, primeiramente, perante o praetor (agente detentor do imperium), e prosseguia em face do iudex (um jurista, a quem o praetor delegava o julgamento da controvérsia - iudicium). A sententia do iudex dava solução definitiva ao litígio (res iudicata), mas seu prolator não dispunha de poder suficiente para dar-lhe execução (As vias de execução do Código de Processo Civil brasileiro reformado. In WAMBIER, Teresa Arruda Alvim (coord). Aspectos polêmicos da nova execução 3: de títulos judiciais, Lei 11.232/2005, São Paulo: Revista dos Tribunais, 2006, p. 289).

${ }^{239}$ THEODORO JR, Humberto. As vias de execução..., cit., p. 290 e 291).
} 
$\mathrm{Na}$ época imperial, dos processos extra ordinem, a condenação continua a exigir a ação de execução, embora existam diferenças em relação à ação de execução do processo romano clássico. Já nos direito dos germânicos, passada a fase do início da Idade Média, em que o credor tinha o direito de fazer valer o seu direito através da força, a lei passou a submeter a penhora a prévia autorização judicial. Aqui, a discussão sobre o direito viria somente na defesa do executado, após a consolidação da penhora. ${ }^{240}$

Diante disso, os autores sustentam ser possível que no curso da história duas formas de execução se chocaram, sendo uma que exigia a ação de execução da sentença condenatória e outra em que se permitia a prática de atos de afetação de bens do devedor, antes de qualquer discussão de direito, para que só mais tarde lhe fosse possível controverter o direito. ${ }^{241}$

Neste sentido, a solução da Idade Média foi boa, já que ao mesmo tempo em que firmou-se a necessidade de o credor submeter a sua afirmação de direito à cognição judicial antes da prática dos atos de execução, permitiu-se que os atos executivos decorressem imediatamente da sentença condenatória, eliminando a ação de execução de sentença. Implantou-se a chamada executio per officium iudicis, na qual a execução da sentença pertencia às atividades do juiz decorrentes de seu ofício, que lhe é atribuído pelo simples fato de haver um julgado. ${ }^{242}$

No final da Idade Média e nos princípios da Idade Moderna, com o surgimento dos títulos de crédito, ressuscitou-se a actio iudicati romana. Durante vários séculos coexistiram as duas formas executivas, sendo a executio per officium iudicis para as sentenças condenatórias e a actio iudicati para os títulos de crédito. Foi nos primórdios do

\footnotetext{
${ }^{240}$ MARINONI, Luiz Guilherme; ARENHART, Sérgio Cruz. Curso de processo civil, volume 3: execução, cit., p. 27.

${ }^{241}$ MARINONI, Luiz Guilherme; ARENHART, Sérgio Cruz. Curso de processo civil, volume 3: execução, cit., p. 27. Na primeira situação abria-se dupla oportunidade para a discussão, uma para permitir a prolação da condenação - a qual exigia a demonstração do direito de crédito - e outra para dar ao condenado o direito de impugnar a subsistência do direito declarado na sentença condenatória. No outro caso, próprio dos povos germânicos, a prática dos atos executivos dispensava a discussão do crédito e a sentença condenatória, bastando um requerimento regular. A discussão do direito, nesta hipótese, ocorria somente se o devedor, após os atos de execução, negasse o direito de crédito, exigindo a sua discussão (ob. cit., p. 27).

${ }^{242}$ THEODORO JR, Humberto. As vias de execução..., cit., p. 292. De acordo com o autor, quem concebeu a ideia de officium iudicis foi Martino de Fano, glosador do século XIII.
} 
século XIX, com o Código de Napoleão, que se tomou a iniciativa de unificar a execução, adotando-se o sistema da actio iudicati inclusive para as sentenças judiciais. ${ }^{243}$

O sistema processual brasileiro seguiu essa sistemática. Contudo, em pleno século $\mathrm{XX}$ voltou-se ao inconformismo com a separação da atividade jurisdicional de cognição e execução em compartimentos estanques. Dessa forma, nos últimos anos do século passado e nos primeiros do atual, o legislador brasileiro, através de reformas ao Código de 1973, está abolindo a dualidade de processos. O processualista mineiro Humberto Theodoro Junior cita quatro etapas para tanto: (i) a alteração do art. 273 pela Lei 8.952/1994, com a possibilidade da antecipação de tutela; (ii) a reforma do art. 461 pela mesma lei, para cumprimento das obrigações de fazer ou não fazer (tutela específica); (iii) introdução do art. 461-A pela Lei 10.444/2002, estendendo a tutela específica às obrigações de entregar coisa; e (iv) reforma da execução por quantia certa pela Lei 11.232/2005. ${ }^{244}$

Athos Gusmão Carneiro, um dos responsáveis pela elaboração da Lei 11.232/05, na mesma linha sustenta que para modernizar o processo de execução tornou-se necessário, através da lei, um parcial retorno aos tempos medievais, mediante a restauração do bom princípio de que sententia habet paratam executionem. Neste sentido, impôs-se o afastamento do formalista, demorado e sofisticado sistema de execução por meio de uma ação autônoma, réplica da actio judicati do direito romano, para retornar à expedita execução per officium iudicis, do direito comum medieval, que deu lugar ao padrão executivo de influência francesa. ${ }^{245}$

De outra parte, Humberto Theodoro Junior, citando a execução no direito de Portugal, Suécia, França, Bélgica, Luxemburgo, Holanda, Grécia, Alemanha e Áustria, afirma que a desjudicialização, ora total, ora parcial, da execução forçada, tem sido uma tônica da evolução por que vem passando o direito processual europeu. Assim, conclui que o direito europeu moderno, se não elimina a judicialidade do cumprimento da sentença, pelo menos reduz profundamente a intervenção judicial na fase de realização da prestação

\footnotetext{
243 THEODORO JR, Humberto. As vias de execução..., cit., p. 293/294.

${ }^{244}$ THEODORO JR, Humberto. As vias de execução..., cit., p. 295/297

245 CARNEIRO, Athos Gusmão. Do 'cumprimento da sentença', conforme a Lei 11.232/2005. Parcial retorno ao medievalismo? Por que não?. In WAMBIER, Teresa Arruda Alvim (coord). Aspectos polêmicos da nova execução 3: de títulos judiciais, Lei 11.232/2005, São Paulo: Revista dos Tribunais, 2006, p. 51. O autor faz uma rica referência histórica no artigo (v. pp. 51-57).
} 
a que o devedor foi condenado. Tal intervenção, quase sempre, se dá nas hipóteses de litígios incidentais surgidos no curso do procedimento executivo. ${ }^{246}$

As reformas brasileiras, por sua vez, não eliminam o caráter jurisdicional da execução de sentença, mas, ao abolir a actio iudicati e tornar consequência imediata do julgado condenatório a expedição de mandado para impor o seu cumprimento à parte, sem as peias da instauração de um novo processo, estão, induvidosamente, colocando o direito processual pátrio no caminho que busca a maior efetividade da prestação jurisdicional perseguida por todos os quadrantes do direito comparado em nosso tempo. ${ }^{247} 248$

Na realidade, o modelo executivo original do CPC não era apenas impotente para viabilizar a tutela ressarcitória na forma específica, mas também incapaz de permitir a obtenção das tutelas inibitória e de remoção do ilícito. Na medida em que o direito de ação tem como corolário o direito aos meios executivos adequados, o CPC por muito tempo foi omisso nesse direito fundamental. ${ }^{249}$

Todavia, o legislador, diante disso, alterou o Código em 1994, quando inseriu as imprescindíveis técnicas antecipatória e executivas dos artigos 273 e $461 .^{250}$ O objetivo da

\footnotetext{
${ }^{246}$ THEODORO JR, Humberto. As vias de execução do Código de Processo Civil brasileiro reformado. In WAMBIER, Teresa Arruda Alvim (coord). Aspectos polêmicos da nova execução 3: de títulos judiciais, Lei 11.232/2005, São Paulo: Revista dos Tribunais, 2006, p. 288. O autor afirma que não há uniformidade na eleição dos meios de simplificar e agilizar o procedimento de cumprimento forçado das sentenças entre os países europeus. Há, porém, a preocupação comum de reduzir, quando possível, a sua judicialização (p. 288/289).

${ }^{247}$ THEODORO JR, Humberto. As vias de execução..., cit., p. 289.

${ }^{248}$ A esse respeito, Humberto Theodoro Jr afirma que não há aqui nenhuma novidade, pois o sistema unitário já vigora de longa data em algumas ações da espécie como as reclamações trabalhistas e as causas de competência dos Juizados Especiais, sem maiores problemas e com resultados positivos em termos de economia processual e efetividade da prestação jurisdicional (THEODORO JR, Humberto. As vias de execução..., cit., p. 310).

${ }^{249}$ MARINONI, Luiz Guilherme; ARENHART, Sérgio Cruz. Curso de processo civil, volume 3: execução, cit., p. 46.

${ }^{250}$ Art. 273. O juiz poderá, a requerimento da parte, antecipar, total ou parcialmente, os efeitos da tutela pretendida no pedido inicial, desde que, existindo prova inequívoca, se convença da verossimilhança da alegação e:

I - haja fundado receio de dano irreparável ou de difícil reparação; ou

II - fique caracterizado o abuso de direito de defesa ou o manifesto propósito protelatório do réu.

$\S I^{o} \mathrm{Na}$ decisão que antecipar a tutela, o juiz indicará, de modo claro e preciso, as razóes do seu convencimento.

$\S 2^{\circ}$ Não se concederá a antecipação da tutela quando houver perigo de irreversibilidade do provimento antecipado.

$\S 3^{\circ}$ A efetivação da tutela antecipada observará, no que couber e conforme sua natureza, as normas previstas nos arts. $588,461, \S \S 4^{\circ}$ e $5^{\circ}$, e 461-A.

$\S 4^{\circ}$ A tutela antecipada poderá ser revogada ou modificada a qualquer tempo, em decisão fundamentada.

$\S 5^{\circ}$ Concedida ou não a antecipação da tutela, prosseguirá o processo até final julgamento.
} 
norma é dar ao jurisdicionado as técnicas processuais necessárias à obtenção da tutela específica do direito material, impedindo sua transformação em dinheiro.

Em outras palavras, o art. 461 não visa o alcance da tutela específica da prestação inadimplida, mas sim a obtenção da tutela específica ou da integridade do direito material. O seu maior escopo é permitir a tutela inibitória, que é a mais relevante espécie de tutela específica - dirigida a inibir o ilícito -, e as tutelas de remoção do ilícito e ressarcitória na forma específica, as quais, apesar de viáveis após a violação da norma - remoção do ilícito - e da produção do dano - ressarcitória na forma específica -, são voltadas a tutelar, na medida do possível, a integridade do direito, evitando a sua degradação em pecúnia. ${ }^{251}$

Dessa forma, o art. 461 dispensou a propositura da ação de execução de sentença em todas as hipóteses em que se pede ao juiz a imposição de obrigação contratual de fazer, e, mais importante que isso, segundo Marinoni e Arenhart, viabilizou a obtenção de toda e qualquer tutela jurisdicional do direito que exija a mera imposição de não fazer ou de fazer, ou a determinação de qualquer meio executivo capaz de assegurar o não fazer ou o fazer, ou ainda que requeira meio executivo suficiente para remover ou eliminar os efeitos concretos do que não deveria ter sido feito pelo réu. ${ }^{252}$

$\S 6^{\underline{o}}$ A tutela antecipada também poderá ser concedida quando um ou mais dos pedidos cumulados, ou parcela deles, mostrar-se incontroverso.

$\S 7^{0}$ Se o autor, a título de antecipação de tutela, requerer providência de natureza cautelar, poderá o juiz, quando presentes os respectivos pressupostos, deferir a medida cautelar em caráter incidental do processo ajuizado.

Art. 461. Na ação que tenha por objeto o cumprimento de obrigação de fazer ou não fazer, o juiz concederá a tutela específica da obrigação ou, se procedente o pedido, determinará providências que assegurem o resultado prático equivalente ao do adimplemento.

$\S 1^{o}$ A obrigação somente se converterá em perdas e danos se o autor o requerer ou se impossível a tutela específica ou a obtenção do resultado prático correspondente.

$\S 2^{\circ}$ A indenização por perdas e danos dar-se-á sem prejuízo da multa (art. 287).

$\$ 3^{\circ}$ Sendo relevante o fundamento da demanda e havendo justificado receio de ineficácia do provimento final, é lícito ao juiz conceder a tutela liminarmente ou mediante justificação prévia, citado o réu. A medida liminar poderá ser revogada ou modificada, a qualquer tempo, em decisão fundamentada.

$\S 4^{\circ}$ O juiz poderá, na hipótese do parágrafo anterior ou na sentença, impor multa diária ao réu, independentemente de pedido do autor, se for suficiente ou compativel com a obrigação, fixando-lhe prazo razoável para o cumprimento do preceito.

$\S 5^{\circ}$ Para a efetivação da tutela específica ou a obtenção do resultado prático equivalente, poderá o juiz, de ofício ou a requerimento, determinar as medidas necessárias, tais como a imposição de multa por tempo de atraso, busca e apreensão, remoção de pessoas e coisas, desfazimento de obras e impedimento de atividade nociva, se necessário com requisição de força policial.

$\S 6^{\circ}$ O juiz poderá, de ofício, modificar o valor ou a periodicidade da multa, caso verifique que se tornou insuficiente ou excessiva.

${ }^{251}$ MARINONI, Luiz Guilherme; ARENHART, Sérgio Cruz. Curso de processo civil, volume 3: execução, cit., p. 47.

${ }^{252}$ MARINONI, Luiz Guilherme; ARENHART, Sérgio Cruz. Curso de processo civil, volume 3: execução, cit., p. 48. 
Oito anos depois, o Código recebeu a norma do art. 461-A, voltada especialmente à tutela dos direitos que dependem apenas da obtenção de coisa imóvel ou móvel. ${ }^{253}$ Neste sentido, é importante ressaltar a distinção entre a ação em que se pede o adimplemento da obrigação de entrega de coisa móvel, a ação que se busca a imissão na posse de coisa móvel ou de coisa imóvel e a ação de recuperação de coisa baseada na defesa da posse ação de reintegração de posse - ou no domínio - ação reivindicatória. ${ }^{254}$

De acordo com Marinoni e Arenhart, o art. 461-A passou a permitir a tutela de imissão na posse e de recuperação de coisa, com base na defesa da posse e do domínio, mediante sentença de executividade intrínseca, isto é, mediante sentença que, ao reconhecer direito material, determina a expedição de mandado, sem a necessidade de condenação e de ação de execução de sentença. A partir do mencionado dispositivo, não há mais execução de sentença em face das obrigações de entrega de coisa móvel ou imóvel. ${ }^{255}$

De outra parte, a par da sistemática da execução do título judicial, o CPC, quando da sua edição, reuniu a execução dos títulos executivos judiciais e extrajudiciais, não apenas outorgando eficácia executiva aos dois e exigindo a ação para o início da execução de ambos, mas aproximando e uniformizando o tratamento para a execução de título executivo extrajudicial e para a execução de sentença. ${ }^{256}$

\footnotetext{
${ }^{253}$ Art. 461-A. Na ação que tenha por objeto a entrega de coisa, o juiz, ao conceder a tutela específica, fixará o prazo para o cumprimento da obrigação.

$\S 1^{o}$ Tratando-se de entrega de coisa determinada pelo gênero e quantidade, o credor a individualizará na petição inicial, se lhe couber a escolha; cabendo ao devedor escolher, este a entregará individualizada, no prazo fixado pelo juiz.

$\S 2^{\underline{o}}$ Não cumprida a obrigação no prazo estabelecido, expedir-se-á em favor do credor mandado de busca e apreensão ou de imissão na posse, conforme se tratar de coisa móvel ou imóvel.

$\S 3^{o}$ Aplica-se à ação prevista neste artigo o disposto nos $\S \S 1^{\underline{o}}$ a $6^{\circ}$ do art. 461.

${ }^{254}$ MARINONI, Luiz Guilherme; ARENHART, Sérgio Cruz. Curso de processo civil, volume 3: execução, cit., p. 50. Prosseguem os autores: a ação de imissão na posse é fundada em direito real. Assim, a sentença de procedência, ao reconhecer o direito à posse, requer somente que o autor seja nela investido, e por isso jamais precisaria condenar o demandado a entregar a coisa. Essa ação exige uma sentença capaz de viabilizar a simples imissão na posse. Ademais, a ação de reintegração de posse e a ação reivindicatória exigem uma sentença que, ao reconhecer a posse e a propriedade, simplesmente abra ensejo para a recuperação da coisa, pois aí não há afirmação de qualquer direito que dependa do cumprimento de uma prestação obrigacional. Ao contrário, a ação de adimplemento se dirige à obtenção de uma prestação devida pelo réu, e assim abre oportunidade a uma forma de execução destinada à realização da prestação que deveria ter sido cumprida pelo demandado (pág. 50).

${ }^{255}$ MARINONI, Luiz Guilherme; ARENHART, Sérgio Cruz. Curso de processo civil, volume 3: execução, cit., p. 50 .

${ }^{256}$ MARINONI, Luiz Guilherme; ARENHART, Sérgio Cruz. Curso de processo civil, volume 3: execução, cit., p. 42/43. O Livro II do CPC supôs que a execução de sentença poderia se contentar com o mesmo tratamento da execução de título extrajudicial.
} 


\subsection{Distinção entre cumprimento da sentença e execução}

De acordo com Athos Gusmão Carneiro, que trabalhou na proposta que resultou na Lei 11.232/05, a epígrafe 'do cumprimento da sentença', usada em vez da habitual expressão 'da execução da sentença', se explica em razão de as obrigações de fazer e de não fazer, e as obrigações de entrega de coisa independerem de 'execução' no sentido estrito e tradicional do termo, pois o mandamento sentencial em favor do demandante será cumprido simplesmente pela expedição de ordem à parte obrigada - eficácia mandamental - ou de mandado a servidor da Justiça ou a pessoa a ele equiparada - eficácia executiva. ${ }^{257}$

Isso, porque segundo referido autor a sentença condenatória, com a Lei 11.232/05, passou a ser também de prevalecente eficácia executiva, ou seja, autoriza o emprego imediato dos meios executivos adequados à efetiva satisfação do credor, sem que a parte vencedora necessite ajuizar nenhum outro processo, sucessivo e autônomo. Assim, a epígrafe 'do cumprimento da sentença', ainda segundo citado processualista, vem a proclamar, de modo expressivo, a meta da última etapa do processo de conhecimento: busca-se a efetivação da sentença condenatória, que resultará na entrega ao demandante do bem da vida a que fora declarado com direito. ${ }^{258}$

Segundo previa o revogado art. 583, toda execução tem por base título executivo judicial ou extrajudicial. Esta disposição é aplicável, subsidiariamente, ao cumprimento das sentenças, a teor do art. 475-R. Por outro lado, o art. 475-I, caput, dispõe que o cumprimento da sentença far-se-á, tratando-se de obrigação por quantia certa, por execução.

Diante disso, Araken de Assis afirma que a primeira conclusão reside no fato de que a Lei 11.232/05 reservou a palavra execução para o cumprimento das resoluções judiciais que contemplem obrigações pecuniárias e, neste caso, a atividade executória tem por base em título executivo judicial. Por tal motivo, e revelando a subsistência, por enquanto parcial, do princípio do título, o art. 475-N não se escusou de contemplar os títulos judiciais. Assim, o art. 475-I, caput, estabelece que o cumprimento da sentença, nos

${ }^{257}$ CARNEIRO, Athos Gusmão. Do 'cumprimento da sentença'..., cit., p. 64.

${ }^{258}$ CARNEIRO, Athos Gusmão. Do 'cumprimento da sentença'..., cit., p. 65. 
demais casos, realizar-se-á conforme os arts. 461 e 461-A, que tratam das obrigações de fazer, não fazer e das obrigações para entrega de coisa. ${ }^{259}$

De acordo com referido processualista gaúcho, a Lei 11.232/05 renegou o princípio da 'execução sem título permitida', por duas razões autônomas: em primeiro lugar, o cumprimento (ou execução) da sentença que agasalhar prestação pecuniária a cargo do vencido realiza-se no mesmo processo, à semelhança das que comtemplem prestações de fazer e de entregar coisa (arts. 461 e 461-A), e, indubitavelmente, fundar-se-á num dos títulos previstos no art. 475-N; ademais, reclama título para o 'cumprimento' das obrigações de fazer e entregar coisa, conforme deflui do art. $475-\mathrm{N}, \mathrm{I}^{260}$

Em outras palavras, a ação não exibe força executiva em decorrência de a execução se realizar no próprio processo. Para Araken de Assis, este é o equivoco básico da proclamação de que, doravante, todas as sentenças são executivas. ${ }^{261}$ Tratando-se de resoluções exequíveis, realmente, reconhece-se à técnica processual a possibilidade de diferir o cumprimento - ou execução - a outro processo, ou realizá-lo no mesmo processo, sem que se admita equiparação entre situações tão diferentes. Não havendo o cumprimento voluntário da obrigação por parte do vencido, mostra-se necessária a atividade judicial complementar ao provimento. Nas palavras do autor, “dar-se o nome de 'execução' ou de 'cumprimento' a tal empresa é de somenos importância". 262

\footnotetext{
${ }^{259}$ ASSIS, Araken de. Sentença..., cit., p. 12.

${ }^{260}$ ASSIS, Araken de. Sentença..., cit., p. 12. Na realidade, segundo o autor, o princípio da execução sem título autorizada, na sua enunciação primitiva, jamais se revelou correto. A execução sem título se prende à força executiva (não, simplesmente, exequível) dos provimentos judiciais. A realização dos atos de cumprimento (ou de execução) no próprio processo em que se originou o pronunciamento representa dado acidental e contingente. Importa a força ou o efeito executivo do provimento (p. 13).

${ }^{261}$ ASSIS, Araken de. Sentença..., cit., p. 13. Neste sentido, o autor afirma que a execução pode se realizar no próprio processo em virtude da estrutura e da função do direito material posto na causa, como por exemplo, na hipótese do locador reaver a coisa locada, tanto que dissolvido o contrato de locação por inadimplemento do locatário (art. 60 da Lei 8.245/1991): o ato executivo recairá sobre bem que, por definição, integra o patrimônio do vitorioso e já se encontra individualizado. É completamente diferente o caso de alguém, vítima de ato ilícito, pretender indenização. Os bens que permitem a satisfação do vitorioso integram, legitimamente, o patrimônio do vencido e devem ser individualizados nos limites do princípio da responsabilidade patrimonial (art. 391 do Código Civil). Na primeira hipótese, a execução é imediata, porque se cuida de resolução dotada de eficácia executiva, e sempre ocorrerá no processo em que surgiu o provimento antecipatório ou final; na segunda, a execução é mediata, porque se origina do efeito executivo da resolução judicial, o provimento é simplesmente exequível, podendo ou não ocorrer no mesmo processo a critério do legislador processual (p. 13).

${ }^{262}$ ASSIS, Araken de. Sentença..., cit., p. 13/15.
} 
Dinamarco, por seu turno, com as alterações introduzidas no Código pelas leis 11.232/05 e 11.382/06 afirma que a execução por sentença ganha mais vigor que nos casos de título extrajudicial. Segundo referido autor, isso se dá em razão da imposição de multa de $10 \%$ ao devedor que não paga em quinze dias da condenação e também pela realização da execução em prosseguimento ao mesmo processo onde foi produzida a sentença, sem nova citação do devedor. ${ }^{263}$

Dessa forma, em princípio o cumprimento da sentença se faz sempre mediante mera fase do processo, sem se instaurar um outro processo para a execução. Contudo, segundo Dinamarco, o CPC prevê três exceções, nas quais o cumprimento da sentença se faz em processo autônomo: (i) o cumprimento da sentença penal condenatória, sentença estrangeira homologada ou sentença arbitral; (ii) o cumprimento de sentença proferida contra a Fazenda Pública (art. 730, CPC e art. 100, CF); e (iii) o cumprimento de sentença condenatória por alimentos. ${ }^{264}$ Já a execução por título extrajudicial dá origem a um processo novo e autônomo, que se instaura pelo ajuizamento de uma petição inicial, inclui a citação do executado e termina por sentença.

Sérgio Shimura, por sua vez, arrola como hipóteses de subsistência de processo autônomo de execução (i) sentença penal condenatória; (ii) sentença arbitral; (iii) sentença estrangeira, homologada pelo STJ; (iv) sentença homologatória de acordo extrajudicial; (v) sentença condenatória, oriunda de ação coletiva, que tenha por objeto ressarcimento de danos a direitos individuais homogêneos; e (vi) pedido de falência, lastreado em ato de insolvência. $^{265}$

Na realidade, nem sempre eram necessários dois processos para a solução de um só conflito, podendo haver até quatro, conforme a situação e a atitude do executado: processo

\footnotetext{
${ }^{263}$ DINAMARCO, Cândido Rangel. Instituições..., vol. IV, cit., p. 455.

${ }^{264}$ DINAMARCO, Cândido Rangel. Instituições..., vol. IV, cit., p. 455. São equivalentes a eficácia dos títulos executivos judiciais e a dos extrajudiciais porque todos dão oportunidade à mesma espécie de tutela jurisdicional, que é a executiva, dispensando um prévio processo de conhecimento ou mesmo qualquer atividade cognitiva como requisito adicional para dar início à execução forçada. À vista do título executivo exibido pelo exeqüente ou já constante dos autos, o juiz simplesmente dá curso ao procedimento executivo, fazendo citar ou intimar o executado, realizando atos de constrição etc., sem se preocupar com a questão de o direito existir, não existir ou ser inferior ao afirmado na petição inicial e indicado no título (ob. cit., p. 238/239).

${ }^{265}$ SHIMURA, Sérgio. A execução da sentença na reforma de 2005. In WAMBIER, Teresa Arruda Alvim (coord). Aspectos polêmicos da nova execução 3: de títulos judiciais, Lei 11.232/2005, São Paulo: Revista dos Tribunais, 2006, p. 560/561.
} 
de conhecimento, o de liquidação (em caso de sentença genérica), o de execução e o dos embargos eventualmente opostos à execução.

A eliminação do binômio de processos, condensando conhecimento e execução em um só, produziu desde logo uma repercussão conceitual, porque nesse quadro a sentença deixava de ser o ato que põe fim ao processo, como visto supra. Nesse quadro sistemático, teve por certo o legislador que a tutela jurisdicional se tornará mais rápida se, em vez de citar pessoalmente o demandado para cada um dos processos sucessivos, forem feitas intimações em seu advogado constituído na causa. ${ }^{266}$

Neste sentido, Dinamarco explica que o legislador pretendeu sedimentar que cumprimento de sentença não se confunde com execução, de forma que as atividades disciplinadas nos arts. 461, 461-A e 475-I e ss. do CPC são mera complementação do que houver sido decidido. Nem por isso, porém, dispensam-se as regras do Livro II. No que diz respeito à execução por quantia certa contra devedor solvente, depois de superada a fase inicial regida pelo art. 475-J, a partir daí praticamente tudo segue as regras do processo autônomo de execução por quantia certa. Da mesma forma, o cumprimento pelos arts. 461 e 461-A do CPC (obrigações de entregar, fazer ou não fazer) também comporta aplicação de normas do Livro II.

Diante disso, didaticamente Dinamarco assim sistematiza o quadro das execuções no processo civil brasileiro: (a) execução por título extrajudicial - processo executivo autônomo; (b) cumprimento de sentença civil proferida por juiz integrante do Poder Judiciário brasileiro $^{267}$; (c) cumprimento de sentença penal, arbitral ou estrangeira processo autônomo; (d) cumprimento da sentença proferida contra a Fazenda Pública processo autônomo; (e) cumprimento de sentença condenatória em alimentos - processo autônomo. ${ }^{268}$ Nestas estão incluídas tanto as execuções por obrigações específicas como as execuções por dinheiro.

O conjunto das técnicas instituídas pelos arts. 461, 461-A e 475-I e seguintes do CPC representa a superação de alguns preciosos dogmas cuidadosamente preservados pela

\footnotetext{
${ }^{266}$ DINAMARCO, Cândido Rangel. Instituições..., vol. IV, cit., p. 461.

${ }^{267}$ Não penal, não árbitro, não juiz estrangeiro.

${ }^{268}$ DINAMARCO, Cândido Rangel. Instituições..., vol. IV, cit., p. 458.
} 
doutrina para segurança das partes, aos quais o legislador entendeu conveniente renunciar com vista à celeridade e maior efetividade da tutela jurisdicional, notadamente com o chamado processo civil sincrético. ${ }^{269}$ Esta, inclusive, é uma previsão que está mantida no projeto de novo código em discussão no Congresso Nacional.

Além disso, ressalte-se a ampliação de poderes dos juízes, posto que já não mais se admite espaço para o juiz omisso, para o juiz burocrata, compilador de jurisprudência ou distanciado do consenso jurídico. ${ }^{270}$ Barbosa Moreira, a esse respeito, afirma que o incremento dos poderes judiciais, ao menos em linha de princípio, pode contribuir de maneira significativa para a consecução dos mesmos fins: simplificar e agilizar a marcha dos feitos e facilitar a prestação jurisdicional em prol de mais eficiente preservação de interesses socialmente relevantes. ${ }^{271}$ José Roberto dos Santos Bedaque, também sobre o tema, sustenta que o juiz deve ir à busca da verdade para solucionar a disputa, não se podendo admitir, por isso, que a vontade dos litigantes seja um empecilho à atividade instrutória oficial. $^{272}$

\section{$2.4 \quad$ Título executivo}

\footnotetext{
${ }^{269}$ Confira-se, a esse respeito, a doutrina de Dinamarco: "a renúncia de maior impacto no sistema tradicional foi a eliminação do binômio processo de conhecimento-processo de execução. Atendendo a ponderações de Humberto Theodoro Junior, formuladas há algumas décadas em sede doutrinária, os Reformadores do Código de Processo Civil (particularmente Athos Gusmão Carneiro) tomaram como certa a premissa de que a dualidade de processos constituiria um entrave ao andamento das causas em juízo e que a citação do executado seria um desconfortável ponto de estrangulamento, responsável pelas longas demoras processuais lamentadas em todos os quadrantes do país. Veio então a idéia, positivada na Lei do Cumprimento de Sentença (lei n. 11.232, de 22.12.05), de condensar em um só processo toda a atividade jurisdicional referente às crises de adimplemento, criando para isso um processo sincrético, que começa com uma fase de conhecimento, não se extingue quando o mérito é julgado e passa depois, quando se trata de dar efetividade ao julgado, a uma segunda fase - a de cumprimento de sentença." DINAMARCO, Cândido Rangel. Instituições..., vol. IV, cit., p. 459.

${ }^{270}$ NALINI, José Renato. O juiz e o acesso à justiça. $2^{\mathrm{a}}$ ed., São Paulo: RT, 2000, p. 18. No mesmo sentido, Antonio Carlos Marcato já se pronunciou: "Foi-se o tempo em que se esperava do juiz um distanciamento do conflito submetido à sua apreciação, como se o resultado final do processo pudesse prescindir da atuação mais efetiva e direta desse sujeito da relação jurídica processual" (A imparcialidade do juiz e a validade do processo, In Revista Direito Mackenzie, São Paulo, vol. 1, n. 2, jul/dez 2000, p. 67).

${ }^{271}$ BARBOSA MOREIRA, José Carlos. Os novos rumos do processo civil brasileiro. In Repro, vol. 78, p. $140 / 141$.

${ }^{272}$ BEDAQUE, José Roberto dos Santos. Poderes Instrutórios do Juiz, $3^{\mathrm{a}}$ ed, São Paulo: RT, 2001, p. 16. Ainda sobre o assunto, José Carlos Baptista Puoli afirma que a tendência de um progressivo aumento dos poderes que são outorgados para o juiz desempenhar sua atividade nos casos concretos encontra justificação no fato de ser nítido que não adianta exigir do juiz uma postura interessada no atendimento dos escopos do processo se não lhe for dado o instrumento legal e os demais meios necessários para o bom desempenho dessa função. Já no estatuto processual de 1939 se verifica essa tendência (Os poderes do juiz..., cit., p. 53).
} 
Para que seja possível a execução, é necessário que o credor possua título executivo. Daí o antigo brocardo nulla executio sine titulo. O título executivo, neste sentido, é muito importante na execução. Sem ele não se pode aferir a causa de pedir, o pedido, nem a legitimidade, interesse de agir, a possibilidade jurídica do pedido, enfim, pode-se dizer que o título executivo é onipotente, pois é o documento indispensável para a propositura da execução e é com base nele que todos os elementos da ação, as condições da ação, requisitos processuais, serão examinados. A cognição na execução recairá sobre o título e tudo o que dele possa ser extraído. ${ }^{273}$

Neste sentido, o título é um documento que comprova um ato jurídico extrajudicial ou a decisão proferida pelo julgador. Não basta o ato para a instauração da execução, é preciso que esteja adequadamente documentado. Por outro lado, o brocardo acima mencionado não pode ser compreendido como uma norma que impõe a certeza jurídica para o início da atividade executiva, de forma que a atividade executiva, provisória ou definitiva, somente pode ser instaurada se for apresentado um instrumento de um ato jurídico a que a lei atribua eficácia executiva. ${ }^{274}$

Dessa forma, o conteúdo do título executivo é um ato jurídico, que é uma norma jurídica concreta que se busca efetivar. Assim, o título não só espelha a relação jurídica exsurgente da incidência da norma abstrata sobre o suporte fático, mas, mais do que isso, ele é portador de uma eficácia típica, que é a de autorizar a outorga de tutela jurisdicional executiva. $^{275}$

De outra parte, existe na doutrina discussão quanto à condição da ação executiva e título executivo. Didier Jr, Cunha, Braga e Oliveira sustentam que o título executivo é, na verdade, documento indispensável à propositura da ação executiva, como requisito de

\footnotetext{
${ }^{273}$ DIDIER JR., Fredie; CUNHA, Leonardo Carneiro da; BRAGA, Paula Sarno; OLIVEIRA, Rafael. Curso de Direito Processual Civil - Execução. Vol. 5, $3^{\mathrm{a}}$ ed., Salvador: JusPodivm, 2011, p. 149.

${ }^{274}$ DIDIER JR., Fredie; CUNHA, Leonardo Carneiro da; BRAGA, Paula Sarno; OLIVEIRA, Rafael. ob. cit., p. $150 / 151$.

${ }^{275}$ DIDIER JR., Fredie; CUNHA, Leonardo Carneiro da; BRAGA, Paula Sarno; OLIVEIRA, Rafael. cit., p. 152. Os autores ainda afirmam que há o título material, que é o ato normativo, que imputa a alguém o dever de prestar, e há o título formal, que é a documentação desse ato jurídico. Esse ato jurídico, uma vez documentado, tem o efeito jurídico de permitir a instauração da atividade executiva para efetivar a norma jurídica nele contida. Em outras palavras, o título executivo é o documento que certifica um ato jurídico normativo, que atribui a alguém um dever de prestar líquido, certo e exigível, a que a lei atribui o efeito de autorizar a instauração da atividade executiva (p. 152).
} 
admissibilidade específico do procedimento executivo, mas não condição da ação. ${ }^{276}$ Dinamarco, por sua vez, entende que o autor carecerá de ação se faltante o título executivo. $^{277}$

O título executivo sujeita-se ao princípio da taxatividade, ou seja, o título só será executivo se estiver em rol legal taxativo (nullus titulus sine legis). No sistema do Código de Processo Civil a mais ampla das divisões entre espécies de técnicas executivas é aquela que considera de um lado a execução fundada em título judicial e, de outro, a execução fundada em títulos extrajudiciais. Todos eles são dotados de eficácia bastante para autorizar a execução e as invasões patrimoniais a ela inerentes. ${ }^{278} 279$

Propõe-se a demanda executiva com o título já nos autos ou anexo à petição inicial e já se passa às medidas preparatórias da satisfação do credor, sem haver espaço, nesse momento, para qualquer prova ou decisão sobre o crédito ou os fatos que lhe hajam dado origem, como era no Código de 1939.

São extremamente numerosos os títulos executivos no processo civil. O Código tem duas listas extensas, a dos títulos judiciais e a dos extrajudiciais, nos artigos 475-N e 585, respectivamente. A reforma do Código que inseriu o processo monitório nos artigos 1.102A a 1.102-C também alargou consideravelmente o rol dos títulos executivos, especialmente

${ }^{276}$ DIDIER JR., Fredie; CUNHA, Leonardo Carneiro da; BRAGA, Paula Sarno; OLIVEIRA, Rafael. cit. p. 152. Para os autores, dizer que o título executivo é condição da ação seria o mesmo que dizer que a prova escrita é condição da ação monitória (CPC, art. 1.102a) e a planta do imóvel é condição da ação de usucapião imobiliária (CPC, art. 942) e que a certidão de casamento é condição da ação de separação judicial.

${ }^{277}$ DINAMARCO, Cândido Rangel. Instituições..., vol. IV, cit., p. 237/238.

${ }^{278}$ Havendo a pretensão resistida, expressão utilizada por Carnelutti na definição de lide, quem vai a juízo, seja a partir da mera afirmação de direito de crédito, seja a partir de título executivo extrajudicial, quer tutela jurisdicional do direito material. No primeiro caso a ação, para prestar a tutela do direito, deve passar pela sentença condenatória, complementando-se com a execução. No segundo a ação dispensa a verificação do direito - e a própria sentença condenatória -, viabilizando a imediata instauração da execução (MARINONI, Luiz Guilherme; ARENHART, Sérgio Cruz. Curso de processo civil, volume 3: execução, cit., p. 30). No primeiro caso, a execução é complemento da ação, enquanto no segundo a execução é a única prestação jurisdicional buscada com a ação.

${ }^{279}$ De qualquer forma, a verdadeira explicação para a equiparação da execução de sentença à execução de título extrajudicial está no princípio da autonomia e da unidade das vias executivas, pouco importando que mais tarde o início da execução tenha passado a depender de autorização judicial ou de ação. De acordo com Marinoni e Alenhart, há uma falsa suposição de que a sentença condenatória é tutela jurisdicional do direito. Equiparar sentença a título executivo extrajudicial é um equívoco que se origina da suposição de que a condenação presta tutela jurisdicional ao direito. Por outro lado, ao se tentar pensar na condenação a partir do direito material, não se consegue qualquer resultado positivo, uma vez que a condenação é incapaz de realizar o direito material ou prestar a tutela do direito. A condenação é, portanto, simples técnica processual, dando contornos a uma espécie de ação que nela finaliza, mas não serve à prestação da tutela jurisdicional do direito (MARINONI, Luiz Guilherme; ARENHART, Sérgio Cruz. Curso de processo civil, volume 3: execução, cit., p. 31/32). 
no âmbito de abrangência do inciso II do art. 585, no qual se agrupam agora ao menos cinco hipóteses referentes a direitos da mais variada natureza (obrigações de pagar dinheiro, de entregar coisa certa, de fazer, de não fazer). ${ }^{280}$

Se o credor não dispõe de um desses títulos, somente alcançará a tutela jurisdicional executiva, depois de certificado o seu direito pelo processo de conhecimento. Obtida a sentença, que torna certa a obrigação cujo adimplemento se persegue, o órgão judicial terá segurança para dar início aos atos de agressão patrimonial contra o devedor, sem necessidade de demonstração, dentro do processo executivo, da existência do direito substancial do credor. Basta o título - neste caso a sentença - para que o processo executivo seja instaurado e seja levado até o final provimento de satisfação do direito do exequente. $^{281}$

Contudo, em face do atual direito positivo brasileiro é insuficiente falar apenas no binômio representado pela execução por título judicial e pela execução por título extrajudicial (processo de execução), porque nem todos os títulos judiciais recebem integralmente o tratamento por lei destinado ao cumprimento de sentença. Segundo Dinamarco, é preciso distinguir, de um lado, a sentença condenatória proferida no processo civil brasileiro (art. 475-N, I e III) ${ }^{282}$ e, de outro, a sentença penal condenatória, a sentença arbitral e a sentença estrangeira homologada pelo STJ (incs. II, IV e VI) ${ }^{283}$. Somente a primeira é suscetível de se projetar como título para a execução que se faz no mesmo processo em que houver sido proferida. ${ }^{284}$

Mesmo quando não se dispõe da sentença, há previsões na lei de documentos negociais cuja força de convencimento se equipara, no terreno da segurança, ao título judicial. Por isso, e em função de política legislativa, esses títulos também se prestam a franquear o acesso à execução forçada, tal como se fossem sentenças. Não tendo, porém,

\footnotetext{
${ }^{280}$ DINAMARCO, Cândido Rangel. Instituições..., vol. IV, cit., p. 237/238

${ }^{281}$ THEODORO JR, Humberto. A sentença declaratória e sua possível força executiva. Tex Pro, 5 abril 2011, disponível em <http://www.tex.pro.br/tex/listagem-de-artigos/324-artigos-abr-2011/7957-a-sentencadeclaratoria-e-sua-possivel-forca-executiva>. Acesso em $4 \mathrm{dez} 2011$.

${ }^{282}$ Respectivamente a sentença proferida no processo civil que reconheça a existência de obrigação de fazer, não fazer, entregar coisa ou pagar quantia e a sentença homologatória de conciliação ou de transação, ainda que inclua matéria não posta em juízo.

${ }^{283}$ Respectivamente a sentença penal condenatória transitada em julgado, a sentença arbitral e a sentença estrangeira, homologada pelo Superior Tribunal de Justiça.

${ }^{284}$ DINAMARCO, Cândido Rangel. Instituições..., vol. IV, cit., p. 241.
} 
passado a obrigação pelo prévio acertamento de uma sentença, eventual discussão a seu respeito em ação de embargos poderá admitir dimensão muito mais ampla do que a tolerada em face do título judicial. Contudo, em resultado prático, segundo Humberto Theodoro Jr, a atividade executiva é a mesma e o mesmo é o resultado da execução forçada, pouco importando seja judicial ou extrajudicial o título. ${ }^{285}$

Os títulos executivos também se sujeitam ao princípio da tipicidade. Enquanto a taxatividade diz respeito à previsão legal, este último refere-se ao tipo expressamente previsto na própria lei, que pode ser fechado ou aberto. Como tipo fechado pode-se citar a nota promissória, cujos pressupostos e requisitos são rígidos, enquanto como tipo aberto é possível citar a hipótese do inciso II do art. 585, que prevê como título executivo qualquer documento particular subscrito pelo devedor e por duas testemunhas. ${ }^{286}$

Ademais, a obrigação representada no título deve ter alguns atributos: ela deve ser certa, líquida e exigível, conforme art. 580 do CPC. Ressalvada a certidão da dívida ativa, não é possível a emissão unilateral do título, nem a configuração de um dos atributos da obrigação nele representada sem que haja a participação do devedor.

\subsubsection{Títulos executivos judiciais}

Os títulos executivos judiciais, como mencionado, estão previstos no art. 475-N do Código. Ali está o rol de decisões que permitem a instauração da atividade executiva pelo Estado. A característica comum a todos eles é a identificação da norma jurídica individualizada que atribua a um sujeito o dever de prestar. A execução de sentença para efetivar uma prestação de fazer ou não fazer se dá segundo o art. 461 do CPC, para efetivar uma prestação de entrega de coisa, segundo o art. 461-A, e para efetivar uma prestação pecuniária, segundo os arts. 475-J a 475-R, conforme dispõe o art. 475-I do CPC.

Há outras disposições no Código versando sobre a executividade de certas decisões judiciárias, mas de um modo ou de outro todas acabam por assimilar-se ao conceito de "sentença proferida no processo civil, que reconheça a existência de obrigação de fazer,

\footnotetext{
${ }^{285}$ THEODORO JR, Humberto. A sentença declaratória..., cit.

${ }^{286}$ DIDIER JR., Fredie; CUNHA, Leonardo Carneiro da; BRAGA, Paula Sarno; OLIVEIRA, Rafael. ob. cit., p. $156 / 157$.
} 
não-fazer, entregar coisa ou pagar quantia" que ali figura como o primeiro dos títulos executivos judiciais, arrolado no inciso I. Isto faz com que todas essas decisões tenham a mesma eficácia executiva das sentenças condenatórias. ${ }^{287}$

Assim, a sentença civil é o primeiro título executivo judicial. O legislador retirou do texto do Código a menção que havia à sentença condenatória, no art. 584, inc. I, para deixar claro que qualquer sentença que reconhecer a existência de uma obrigação exigível o que em nosso entendimento inclui a declaratória- tem eficácia executiva.

A esse respeito, antes mesmo da reforma implementada pela Lei 11.232/05, o processualista e ministro do Superior Tribunal de Justiça Teori Albino Zavascki já previa em sede doutrinária que são títulos executivos judiciais as sentenças proferidas no processo civil, que definam, de modo completo, uma norma jurídica individualizada que contenha prestação exigível de pagar quantia, cuja execução forçada deva se dar em ação autônoma. Neste sentido, afirma que sentença com essas características pode decorrer do julgamento de qualquer espécie de ação, e não apenas no de procedência de ação condenatória. ${ }^{288}$

Referido autor ainda afirmava que não era exaustivo o rol dos títulos executivos judiciais do art. 584 do Código, pois outros provimentos jurisdicionais possuem força executiva, que lhes é atribuída ou por disposição normativa explícita, ou pelo próprio sistema. Assim, ao legislador ordinário não é dado negar executividade a norma jurídica concreta certificada por sentença se nela estiverem presentes todos os elementos identificadores da obrigação - sujeitos, prestação, liquidez, exigibilidade -, pois isso

\footnotetext{
${ }^{287}$ DINAMARCO, Cândido Rangel. Instituições..., vol. IV, cit., p. 245. O jurista faz a relação dos títulos executivos instituídos pelo CPC em disposições esparsas: a) o mandado de pagamento ou entrega, que se expede no processo monitório, embora não contenha a declaração de existência do direito e não seja sequer uma sentença (art. 1.102-C); b) a sentença que, julgando procedente a denunciação da lide, serve de suporte para a execução a ser movida pelo denunciante ao denunciado (art. 76); c) a que, ao julgar procedente demanda do autor, vale como título em benefício deste em face do terceiro chamado ao processo (art. 80); d) a que, na ação de consignação em pagamento, julga insuficiente o depósito feito pelo autor (art. $889, \S 2^{\circ}$ ); e) a que julga procedente a demanda do vizinho em face dos condôminos, com a condenação destes a restituir parte do imóvel que houver sido objeto de ação de divisão processada entre estes (art. 949, par.); f) a decisão que manda o arrematante inadimplente pagar o valor da arrematação e a multa (art. 695, § $1^{\circ}$ ). Em todos esses casos, ainda quando não fale expressamente em condenação o CPC diz sempre que haverá um título executivo - e essas disposições, quando lidas à luz do conceito de sentença condenatória, revelam-se como autênticas condenações e como tais devem ser tratadas (ob. cit., p. 246).

${ }^{288}$ ZAVASCKI, Teori Albino. Processo de execução: parte geral, cit., p. 290. Como se verá no Capítulo 3, tal entendimento também foi defendido pelo autor em seus julgados do STJ.
} 
representaria atentado ao direito constitucional à tutela executiva, que é inerente ao complemento necessário do direito de ação. ${ }^{289}$

Humberto Theodoro Jr também afirma que em alguns casos de jurisdição voluntária, como na separação consensual, pode-se ensejar a execução forçada, quando um dos cônjuges se negar a cumprir o acordo da planilha do patrimônio do casal ou deixe de pagar pensão alimentícia convencionada. Da mesma forma, a sentença exequível tanto pode provir de processo de conhecimento, como de processo cautelar, pouco importando se o procedimento tenha sido ordinário, sumário ou especial. ${ }^{290}$

Por tal motivo, concluiu-se acima ${ }^{291}$ que, diante da previsão do art. 475-N, inciso I, a diferenciação entre a sentença condenatória e as demais deixou de ser relevante sob o ponto de vista executivo. A preocupação do operador do direito será identificar se a sentença terá ou não carga executiva, à luz da mencionada disposição legal, independente da classificação que a ela se atribua. ${ }^{292}$

Na legislação estrangeira comparada, é possível encontrar a previsão acerca dos títulos executivos judiciais, de forma que nem sempre é indicada expressamente como sendo a sentença condenatória. A lei processual italiana, por exemplo, não distingue os títulos executivos judiciais dos extrajudiciais e prevê no item 1 do art. 474 do Código como título executivo as sentenças, e as providências às quais a lei atribui expressamente eficácia executiva. O legislador português igualmente não diferencia os títulos em judiciais e extrajudiciais e prevê no art. 46, item 1, alínea "a" do Código as sentenças condenatórias como aptas a servir de base à execução. ${ }^{293} 294$

\footnotetext{
${ }^{289}$ ZAVASCKI, Teori Albino. Processo de execução: parte geral, cit., p. 308. O autor explica que nem sempre sentença com tal conteúdo se amolda ao que a doutrina tradicional define como sentença condenatória, podendo ajustar-se ao conceito de sentença declaratória. Tudo depende do modo como se concebe uma e outra, e esse é tema em que a polêmica doutrinária é antiga e persistente. E segue: "o dogma de que somente a sentença condenatória é título executivo tem forçado seus adeptos a ampliar cada vez mais o conceito de condenação. Chega-se ao ponto de definir como sentença condenatória aquela que propicia a formação de título executivo, definição que mantém o dogma, mas que não define nada. Os que sustentam que a sentença condenatória é a que constitui ou faz operar a sanção, encontram dificuldade em explicar a força executiva de decisões em que não há imposição de sanção" (ob. cit., p. 309).

${ }^{290}$ THEODORO JR, Humberto. Processo de Execução e Cumprimento da Sentença, cit., p. 600.

${ }^{291}$ V. item 1.2.3.

292 Acerca da carga executiva da sentença civil, v. Capítulo 3.

${ }^{293}$ PEREIRA, Rafael Caselli. O dogma da condenatoriedade - a sentença declaratória como título executivo judicial. Disponível na página da Academia Brasileira de Direito Processual Civil (www.abdpc.org.br), acesso em 6/1/2012.
} 
A lei espanhola, por sua vez, dispõe no art. 517, item 2.1 como título executivo judicial "la sentencia de condena firme", sendo que no item 2.9, inserido no Código pela lei 37 de 10 de outubro 2011 - medidas de agilização processual - prevê também como título executivo "las demás resoluciones procesales y documentos que, por disposición de esta u otra Ley, lleven aparejada ejecución". O art. 521, item 1, do mesmo Código de Processo prevê que as sentenças meramente declaratórias e constitutivas não poderão dar ensejo à execução, apesar de o item 3 deste artigo possibilitar a execução de pronunciamentos de condenação contidos em sentença constitutiva. ${ }^{295}$

Já a lei francesa prevê no art. $3^{\circ}$ da Lei no 91-650, de 9 de Julho de 1991, relativa à reforma dos processos civis de execução, como título executivo judicial as sentenças dos tribunais judiciais ou dos tribunais administrativos, bem como as transações submetidas ao presidente do "tribunal de grande instance", sempre que tenham força executória, isto é, que não sejam suscetíveis de recurso suspensivo da execução. E a lei alemã dispõe que as decisões finais transitadas em julgado ou que tenham provisoriamente força executória são títulos executivos (artigo 704 do Código de Processo Civil - ZPO), como também os demais instrumentos executivos referidos no artigo 794.

Na América Latina, é possível citar a lei argentina, que prevê no art. 499 sobre a execução de sentença de tribunais argentinos, no sentido de "Consentida o ejecutoriada la sentencia de UN (1) tribunal judicial o arbitral y vencido el plazo fijado para su cumplimiento, se procederá a ejecutarla, a instancia de parte", de acordo com as regras do capítulo. Na Colombia, o art. 488 do Código prevê que podem ser executadas obrigações

\footnotetext{
${ }^{294}$ A esse respeito, Humberto Theodoro Junior leciona que a doutrina portuguesa costuma classificar os títulos executivos provenientes do processo em judiciais e parajudiciais. Aqueles seriam a sentença de condenação, e estes a de homologação de transação acordada entre as partes, onde há um misto de título judicial e extrajudicial, limitando-se o juiz a dar eficácia ao ato das partes, sem julgá-lo (Processo de Execução e Cumprimento da Sentença, $26^{a}$ ed., São Paulo, Liv. e Ed. Universitária de Direito, 2009, p. 596).

${ }^{295}$ Artículo 521. Sentencias meramente declarativas y sentencias constitutivas.

1. No se despachará ejecución de las sentencias meramente declarativas ni de las constitutivas.

2. Mediante su certificación y, en su caso, el mandamiento judicial oportuno, las sentencias constitutivas firmes podrán permitir inscripciones y modificaciones en Registros públicos, sin necesidad de que se despache ejecución.

3. Cuando una sentencia constitutiva contenga también pronunciamientos de condena, éstos se ejecutarán del modo previsto para ellos en esta Ley.
} 
expressas, claras e exigiveis que emanem de sentença condenatória proferida por juiz ou tribunal de qualquer jurisdicão. ${ }^{296}$

No Chile, o art. 434, que prevê o procedimento executivo das obrigações de dar, define como título executivo a sentencia firme, bien sea definitiva o interlocutoria, disposição que também é aplicável às obrigações de fazer e não fazer (art. 530). Já no Uruguai, o art. 372 disciplina a execução de sentença, que será possível após esta tornar-se definitiva, sem prejuízo da execução provisória no caso dos arts. 260 e 275 . O item 372.4 cita o condenado, dando a entender que a sentença terá de ser condenatória. Por fim, o Código do Paraguai prevê no art. 448 os títulos executivos e no art. 475 e seguintes especificamente o cumprimento da sentença (del cumplimento de la sentencia), quando definitiva. $^{297}$

De outra parte, há casos em que o título para a execução forçada é decisão interlocutória, e não sentença ou acórdão. Teori Zavascki afirma que é o que ocorre (a) na execução de alimentos provisionais estipulados initio litis (art. 733 do CPC), (b) nos casos de antecipação de tutela, quando os atos de execução devam ser cumpridos em ação autônoma, (c) quando o juiz, no curso do processo, impõe ao executado multa por ato atentatório à dignidade da justiça (art. 601 do CPC) ou (d) impõe multa por atraso no cumprimento de obrigação de fazer ou não fazer (art. $461, \S 4^{\circ}$ e art. 645 do CPC). ${ }^{298}$

Por outro lado, o segundo título executivo judicial previsto no art. 475-N é a sentença penal condenatória transitada em julgado. A sentença deve ser, portanto, definitiva e deverá a vítima, seu representante legal ou seus herdeiros promover a liquidação do quantum da indenização a que tem direito.

\footnotetext{
296 “Art. 488.- Títulos ejecutivos. Pueden demandarse ejecutivamente las obligaciones expresas, claras y exigibles que consten en documentos que provengan del deudor o de su causante y constituyan plena prueba contra él, o las que emanen de una sentencia de condena proferida por juez o tribunal de cualquier jurisdicción, o de otra providencia judicial que tenga fuerza ejecutiva conforme a la ley, o de las providencias que en procesos contencioso - administrativos o de policía aprueben liquidación de costas o señalen honorarios de auxiliares de la justicia.

La confesión hecha en el curso de un proceso no constituye título ejecutivo, pero sí la que conste en el interrogatorio previsto en el artículo 294."

297 "Art.475.- Dinero embargado. Pago inmediato. Cuando lo embargado fuese dinero, una vez firme la sentencia, el acreedor practicará la liquidación del capital, intereses y costas, de que se dará traslado al ejecutado. Aprobada la liquidación, se hará pago inmediato al acreedor del importe que de ella resultare"

${ }^{298}$ ZAVASCKI, Teori Albino. Processo de execução: parte geral, cit., p. 290. O autor sustenta que também é título executivo a decisão que, sem extinguir o processo, condena uma das partes no pagamento de custas e honorários advocatícios, como, por exemplo, quando exclui litisconsorte da relação processual fazendo incidir ali ônus sucumbenciais.
} 
O terceiro título executivo judicial é a sentença homologatória de conciliação ou de transação, ainda que inclua matéria não posta em juízo. Tal sentença é, de acordo com o art. 269, inc. III do CPC, de mérito, acobertada pela coisa julgada material. A conciliação homologada judicialmente pode versar sobre matéria não posta em juízo desde que o magistrado seja competente para examiná-la.

A esse respeito, Didier Jr, Cunha, Braga e Oliveira ressaltam que é possível a autocomposição após a coisa julgada. A coisa julgada torna indiscutível o reconhecimento do direito, o qual, se disponível, pode ser objeto de transação ou renúncia. É possível, então, que as partes alterem os termos da relação jurídica reconhecida judicialmente. $\mathrm{O}$ acordo pode ser levado para homologação judicial e implica novação, a despeito de não haver necessidade, posto que a homologação serve para consolidar a novação, extinguindo a obrigação constante do anterior título executivo judicial. ${ }^{299}$

O quarto título executivo judicial é a sentença arbitral, que, após a Lei 9.307/1996, passou a ter eficácia idêntica à sentença judicial, para fins de execução forçada. É correta a opção do legislador de incluir a sentença arbitral como título executivo judicial, pois a doutrina majoritária entende que a arbitragem no Brasil tem natureza de atividade jurisdicional. ${ }^{300}$ Em razão disso, reduz-se a amplitude de defesa do executado, nos termos do art. 475-L do CPC, não podendo o Poder Judiciário rever o conteúdo do que foi decidido pelo árbitro ou árbitros. Na eventualidade de a sentença arbitral ser ilíquida, impõe-se antes de ser executada, a instauração de uma ação autônoma de liquidação. ${ }^{301}$

\footnotetext{
${ }^{299}$ DIDIER JR., Fredie; CUNHA, Leonardo Carneiro da; BRAGA, Paula Sarno; OLIVEIRA, Rafael. ob. cit., p. 168.

${ }^{300}$ Carlos Alberto Carmona, um dos maiores estudiosos da arbitragem no Brasil, é um dos defensores da natureza jurisdicional da atividade do árbitro. Isso, tendo em vista que o art. 31 da lei de arbitragem determina que a decisão final dos árbitros produzirá os mesmos efeitos da sentença estatal, constituindo a sentença arbitral título executivo que, embora não oriundo do Poder Judiciário, assume a categoria de judicial. Conforme Carmona, o legislador optou, assim, por adotar a tese da jurisdicionalidade da arbitragem, pondo termo à atividade homologatória do juiz, fator de emperramento da arbitragem. Diante dessa constatação, a lei dispôs que a sentença arbitral não precisa mais passar pelo controle prévio dos órgãos do Estado para receber a oficiliazação que lhe era outorgada pela sentença de homologação. Não quer isso dizer, no entanto, que não seja possível questionar em juízo a validade e eficácia da sentença arbitral. Para esse fim, estabeleceu-se o procedimento do art. 33 (Arbitragem e processo: um comentário à Lei $n^{o}$ 9.307/96. $2^{\mathrm{a}}$ ed, São Paulo: Atlas, 2006, p. 45).

${ }^{301}$ DIDIER JR., Fredie; CUNHA, Leonardo Carneiro da; BRAGA, Paula Sarno; OLIVEIRA, Rafael. ob. cit., p. $168 / 169$.
} 
O quinto título executivo judicial é o acordo extrajudicial, de qualquer natureza, homologado judicialmente. A homologação ocorrerá após a instauração de um procedimento de jurisdição voluntária, em que o magistrado examinará o preenchimento dos pressupostos e requisitos para a celebração do negócio jurídico. A esse respeito, o art. 57 da lei 9.099/1995 dispõe que o acordo extrajudicial, de qualquer natureza ou valor, poderá ser homologado, no juízo competente, independentemente de termo, valendo a sentença como título executivo judicial. Assim, é possível pelo Juizado Especial Cível a homologação do acordo, qualquer seja sua natureza ou valor.

Ressalte-se que tal título não se confunde com o acordo extrajudicial, que é título executivo extrajudicial, na forma do art. 585, II do CPC. O mesmo está disposto no parágrafo único do citado art. 57 da lei 9099/99, no sentido de que valerá como título extrajudicial o acordo celebrado pelas partes, por instrumento escrito, referendado pelo órgão competente do Ministério Público. Para este, a defesa do executado é mais ampla, nos termos do art. 745 do CPC, enquanto a do título judicial é restrita aos limites do art. 475-L. Dessa forma, o mesmo acordo poderá ser executado como título executivo judicial ou extrajudicial, dependendo de como o credor atuar em conjunto com o devedor. ${ }^{302}$

O sexto título executivo judicial é a sentença estrangeira, homologada pelo STJ. Ressalte-se que a competência do STJ foi atribuída pela EC 45 de 2004 (art. 105, I, $i$ da $\mathrm{CF} / 88$ ), sendo que até então era o STF a Corte constitucionalmente competente para tanto. Aqui, podem ser consideradas tanto as sentenças judicias quanto as sentenças arbitrais, observado, quanto a estas, o que dispuser a legislação de origem. ${ }^{303}$

A sentença estrangeira será necessariamente líquida, pois ao passar ao juízo de delibação do STJ já terá sido liquidada no seu país de origem. A decisão homologatória de sentença estrangeira tem caráter constitutivo, nacionalizando-a e atribuindo-lhe idêntica eficácia à sentença proferida pelos juízes brasileiros. Enquanto não homologada, a sentença não produz efeitos no território brasileiro, não podendo ser considerada título executivo, nem servir como base para a instauração de uma execução. A competência para

\footnotetext{
${ }^{302}$ DIDIER JR., Fredie; CUNHA, Leonardo Carneiro da; BRAGA, Paula Sarno; OLIVEIRA, Rafael. ob. cit., p. $169 / 170$.

${ }^{303}$ CARREIRA ALVIM, José Eduardo. Execução de sentenças penal, arbitral e estrangeira (art. 475-N, parágrafo único, do CPC) - Processo de execução ou execução sincretizada (cumprimento)?. In WAMBIER, Teresa Arruda Alvim (coord). Aspectos polêmicos da nova execução 3: de títulos judiciais, Lei 11.232/2005, São Paulo: Revista dos Tribunais, 2006, p. 333.
} 
processar a execução da sentença estrangeira é da Justiça Federal em primeiro grau de jurisdição, conforme art. 109, inc. X da Constituição Federal. ${ }^{304}$

O sétimo e último título executivo judicial previsto no rol do art. 475-N do CPC é o formal e a certidão de partilha, exclusivamente em relação ao inventariante, aos herdeiros e aos sucessores a título singular ou universal. A partilha dos bens, feita em inventário ou arrolamento, é homologada por sentença, representada por formal ou certidão de partilha. O formal é um caderno processual, composto por peças que compuseram o processo de inventário ou arrolamento. Ou seja, o formal é uma carta de sentença (ou carta de cumprimento), com as peculiaridades do art. 1027 do CPC para sua extração.

Para Didier Jr, Cunha, Braga e Oliveira o inciso VII do art. 475-N deve ser interpretado extensivamente, para abranger as sentenças que homologuem partilha inter vivos, como nos casos de divórcio ou de dissolução da sociedade empresária. ${ }^{305}$

O parágrafo único do mencionado artigo ainda prevê que nos casos dos incisos II, IV e VI - isto é, sentença penal condenatória transitada em julgado, sentença arbitral e sentença estrangeira homologada pelo STJ - o mandado inicial do art. 475-J incluirá a ordem de citação do devedor, no juízo civil, para liquidação ou execução, conforme o caso.

\subsection{Obrigação de fazer, não fazer, entregar coisa e pagar quantia}

A circunstância de a sentença impor um fazer, por exemplo, não significa que se esteja diante de uma ação que almeja um fazer ou de uma tutela de obrigação de fazer. O fazer, o não fazer, a entrega de coisa ou o pagamento de quantia são, de acordo com Marinoni e Arenhart, apenas os meios instrumentais para a prestação da tutela do direito e

\footnotetext{
${ }^{304}$ DIDIER JR., Fredie; CUNHA, Leonardo Carneiro da; BRAGA, Paula Sarno; OLIVEIRA, Rafael. ob. cit., p. 170. Os autores ressaltam que de acordo com o Protocolo de Las Leñas, assinado em 27.06.1992 e aprovado pelo Decreto Legislativo 55 de 28.04.1995, que compõe o processo de integração dos países do MERCOSUL, a execução de sentenças proferidas por autoridade judiciária de um dos países-membros processar-se-á perante outro país-membro de acordo com o procedimento mais simples de expedição de carta rogatória, e não o de homologação de sentença estrangeira (ob. cit., p. 171).

${ }^{305}$ DIDIER JR., Fredie; CUNHA, Leonardo Carneiro da; BRAGA, Paula Sarno; OLIVEIRA, Rafael. ob. cit., p. 172.
} 
não têm correspondência com as tutelas de direitos, podendo qualquer um deles permitir a outorga de várias tutelas jurisdicionais. ${ }^{306}$

Ainda que o fazer, o não fazer, a entrega de coisa e o pagamento de quantia sejam apenas os resultados esperados por quem deseja a tutela do direito, cada um deles se liga a meios de execução diversos. Assim, o fazer e o não fazer têm à sua disposição, além da multa (astreinte), todo e qualquer meio de execução idôneo e necessário a determinado caso concreto, conforme $\S \S 4^{\circ}$ e $5^{\circ}$ do art. 461 do CPC. ${ }^{307}$

A entrega de coisa, por sua vez, pode se valer, conforme o caso, da imissão na posse, da busca e apreensão e da multa (astreinte). Já o pagamento de quantia pode ser obtido mediante as técnicas executivas da execução por expropriação, isto é, mediante penhora, avaliação, expropriação e pagamento do credor, sendo que em situações excepcionais como a do devedor de alimentos pode-se utilizar de técnicas mais incisivas, como desconto em folha, o desconto de rendas periódicas e até mesmo a prisão. ${ }^{308}$

Ressalte-se que as obrigações de fazer são típicas ações positivas e concretizam-se por meio de um ato do devedor, correspondendo normalmente a prestação de trabalho, que pode ser físico, intelectual ou artístico. São exemplos comuns a contratação da pintura de quadro, da reforma de um automóvel, da construção de uma casa, da realização de um espetáculo artístico, da demolição de um prédio e tantos outros modos de criar coisas ou fatos novos. Às vezes a prestação é personalíssima - infungível -, outras vezes não. ${ }^{309} \mathrm{O}$ Código Civil de 2002 regula nos arts. 247 a 249 a obrigação de fazer.

\footnotetext{
${ }^{306}$ MARINONI, Luiz Guilherme; ARENHART, Sérgio Cruz. Curso de processo civil, volume 3: execução, cit., p. 65. Em outras palavras, quem deseja determinada tutela jurisdicional do direito pode necessitar de um fazer, de um não fazer, da entrega de coisa ou do pagamento de quantia, mas isto está muito longe de poder permitir o encobrimento ou o esquecimento da verdadeira natureza daquilo que se busca em juízo.

307 O juiz, ara tornar viável a efetivação da tutela específica ou a obtenção do resultado equivalente, adotará na sentença condenatória ou em ato subsequentes as medidas assessorias ou de apoio, que são utilizadas para compelir o devedor a realizar a prestação devida ou a facilitar a atividade jurisdicional satisfativa. A primeira dessas medidas é a multa diária (astreinte - figura originada do direito francês), que o juiz pode impor ao devedor pela demora no cumprimento da prestação, a requerimento do credor ou de ofício. A enumeração das medidas no dispositivo é meramente exemplificativa, tendo o juiz poder para tomar outras providências práticas compatíveis com o tipo de obrigação a cumprir e com os princípios que fundamentam o devido processo legal.

${ }^{308}$ MARINONI, Luiz Guilherme; ARENHART, Sérgio Cruz. Curso de processo civil, volume 3: execução, cit., p. 65 .

309 THEODORO JR, Humberto. Processo de Execução e Cumprimento da Sentença, cit., p. 551.
} 
Já as obrigações de não fazer são tipicamente negativas, ficando o devedor obrigado a uma abstenção, devendo manter-se numa situação omissiva - non facere. É pela inércia que se cumpre a prestação devida e, caso faça aquilo que se obrigou a não fazer, a obrigação estará irremediavelmente inadimplida. Os arts. 250 e 251 do Código Civil dispõem sobre a obrigação de não fazer. Assim, a execução forçada, nesse caso, se endereça ao desfazimento daquilo que indevidamente se fez, e se isto não for possível, converte-se em reparação de perdas e danos. Ao cumprimento forçado, em juízo, da prestação na forma prevista no título da obrigação de fazer ou não fazer, atribuiu-se o nomem iuris de tutela específica, conforme previsão do caput do art. $461 .^{310}$

A obrigação de entregar coisa ou de dar, por sua vez, é modalidade de obrigação positiva, cuja prestação consiste na entrega ao credor de um bem corpóreo, seja para transferir-lhe a propriedade, seja para ceder-lhe a posse, seja para restituí-la. O Código civil dispõe em seus artigos 233 a 246 acerca das obrigações de dar coisa certa e incerta. Toda execução de entrega de coisa, em princípio, deve ocorrer de "forma específica", nos termos previstos no art. 461-A do CPC, pouco importando que a prestação decorra de direito real ou pessoal, de obrigação convencional ou legal. ${ }^{311}$

A última a ser contemplada no sistema executivo do processo civil sincrético, a obrigação por quantia certa é aquela que se cumpre por meio de dação de uma soma de dinheiro. O débito pode provir de obrigação originariamente contraída em torno de dívida de dinheiro - como no caso do mútuo, compra e venda, locação, prestação de serviço -, ou pode resultar da conversão de obrigação de outra natureza no equivalente econômico indenização por descumprimento de obrigação de entrega de coisa, ou de prestação de fato, reparação de ato ilícito etc. ${ }^{312}$

Tratando-se de obrigação de pagar, os meios disponíveis a um imediato adimplemento forçado revelam-se inadequados, dada a necessidade de expropriar bens do

310 THEODORO JR, Humberto. Processo de Execução e Cumprimento da Sentença, cit., p. 552. O sistema de cumprimento de sentença tem como principal característica a dispensa da velha ação executória, já que todas as providências previstas no caput e nos parágrafos do art. 461 hão de ser tomadas de imediato, ainda no processo de conhecimento. Tais sentenças são condenatórias, mas imediatamente executivas (sentenças executivas lato sensu).

311 THEODORO JR, Humberto. Processo de Execução e Cumprimento da Sentença, cit., p. 571.

312 THEODORO JR, Humberto. Processo de Execução e Cumprimento da Sentença, cit., p. 577. 
patrimônio do devedor a fim de, pela sua alienação, obter recursos financeiros que permitam a satisfação da dívida.

Nestes casos, o cumprimento da sentença far-se-á mediante 'execução' - mantida, embora em sede de cumprimento da sentença, a tradicional denominação pelo art. 475-I, caput - observados, no que couber, as regras e os procedimentos pertinentes ao processo de execução - aqui, processo de execução propriamente dito - de título executivo extrajudicial. Eventualmente, os próprios bens expropriados podem ser utilizados na solução do crédito exequendo por meio de adjudicação. ${ }^{313}$

Cite-se, ainda, o cumprimento de sentença que condena ao cumprimento de obrigação de declarar vontade. O Código de 1939 rompeu com antigo entendimento de que ato de vontade era personalíssimo, adotando a fungibilidade dessas prestações e admitindo o suprimento da declaração de vontade omitida por uma manifestação judicial equivalente. A Lei 11.232/05 inseriu no Código de 1973 os arts. 466-A a 466-C, deslocando o regime do julgado do campo da execução para o dos efeitos da sentença. Referidos dispositivos preveem os efeitos da sentença que condena a declarar vontade, de forma a suprir a falta do obrigado.

\subsection{Execução provisória}

Execução provisória, em regra, só pode ocorrer em casos de títulos executivos judiciais e tem caráter excepcional. Ocorre quando a situação do credor é passível de ulteriores modificações, pela razão de que a sentença que reconheceu seu crédito não se tornou definitiva, dada a inexistência de coisa julgada. A lei, portanto, abre certas exceções à regra de que a sentença só pode ser executada quando definitiva, levando em conta a distinção que se pode fazer entre eficácia e imutabilidade da sentença. ${ }^{314}$ Confirmada a sentença no grau de recurso, a execução provisória transmuda-se, automaticamente, em definitiva.

313 Humberto Theodoro Jr, ao fazer um balanço da reforma intentada pela Lei 11.232/05, critica o excesso de normatização do procedimento que condena ao pagamento de quantia certa, na medida em que praticamente todas as regras da extinta ação de execução foram explicitadas (ob. cit., p. 582).

314 A respeito dos efeitos da sentença, v. item. 1.2.2. 
Assim, em circunstâncias especiais, a lei confere eficácia a determinadas decisões, mesmo antes de se tornarem imutáveis. É o que ocorre quando o recurso interposto é recebido apenas no efeito devolutivo. Por outro lado, o efeito suspensivo do recurso não se confunde com recorribilidade, que impede a sentença de produzir efeitos pelo simples fato de ainda poder ser objeto de recurso.

O procedimento que orienta o cumprimento provisório da sentença é basicamente o mesmo do definitivo, de acordo com os arts. 475-O e 475-I, $\S 1^{\circ}$ do CPC. A execução provisória corre por iniciativa, conta e responsabilidade do exequente. E fica sem efeito sobrevindo acórdão que modifique ou anule a sentença objeto da execução, restituindo-se as partes ao estado anterior. Nos casos de levantamento de depósito em dinheiro e de prática de atos que importem alienação de propriedade sobre os bens exequendos, a execução provisória só se ultimará mediante caução suficiente e idônea. Além disso, as prestações de natureza alimentar ou decorrentes de ato ilícito pode ser executadas provisoriamente, com dispensa de caução, nas hipóteses legais. E caso ocorra modificação ou anulação parcial da sentença, a execução provisória ficará sem efeito nessa parte. ${ }^{315}$

\subsection{Defesas do executado}

De acordo com o acima estudado, na versão original do CPC de 1973, a tutela jurisdicional executiva realizava-se, quase que exclusivamente, de acordo com o modelo previsto no Livro II do Código, o qual estabeleceu a unificação procedimental das ações executivas, impondo-se o mesmo procedimento para as ações de execução fundadas em títulos executivos judiciais quanto extrajudiciais, distinguindo-se, apenas, as matérias que poderiam ser arguidas nos embargos à execução fundada em título judicial (art. 741) e em título extrajudicial (art. 745). ${ }^{316}$

Uma vez que não há mais ação de execução de sentença civil, desaparece também a ação incidental de embargos do devedor. Sendo única a relação processual, as matérias de

315 THEODORO JR, Humberto. Processo de Execução e Cumprimento da Sentença, cit., p. 618/620.

${ }^{316}$ Desse modo, assim como a execução fundada em título extrajudicial, também a execução de sentença era, de acordo com a versão originária do CPC, realizada em processo autônomo e, por tal razão, as defesas que o executado poderia opor à execução deveriam ser apresentadas em ação de conhecimento distinta da ação de execução (MEDINA, José Miguel Garcia; WAMBIER, Luiz Rodrigues; WAMBIER, Teresa Arruda Alvim. Sobre a impugnação à execução de título judicial (arts. 475-L e 475-M do CPC). In WAMBIER, Teresa Arruda Alvim (coord). Aspectos polêmicos da nova execução 3: de títulos judiciais, Lei 11.232/2005, São Paulo: Revista dos Tribunais, 2006, p. 398). 
defesa devem, em princípio, ficar restritas à contestação, onde toda resistência oponível à pretensão do credor haverá de ser exposta. No entanto, como os atos executivos sujeitamse a requisitos legais, não se pode pretender realizá-los sem propiciar às partes o adequado controle de legalidade. Assim, o art. 475-J, § $1^{\circ}$ prevê o direito do devedor de oferecer impugnação, nos 15 dias que se seguem à intimação da penhora e avaliação. ${ }^{317}$

A impugnação à execução de títulos judiciais está regulada nos arts. 475-L e 475-M do CPC, e não se desenvolve de modo procedimentalmente autônomo. A oposição à execução, na sistemática implantada pela Lei 11.232/05, realiza-se incidentalmente, no mesmo procedimento em que estão sendo realizados os atos executivos. ${ }^{318}$

A esse respeito, debate a doutrina acerca da natureza jurídica da impugnação, se de ação ou de incidente processual. Dinamarco afirma que tanto a impugnação quanto os embargos se desenvolvem e recebem julgamento em um autêntico processo incidente à execução, não em mero incidente. ${ }^{319}$ Por outro lado, José Miguel Garcia Medina, Luiz Rodrigues Wambier e Teresa Arruda Alvim Wambier defendem que a impugnação pode ter natureza de mera defesa incidental - nos casos em que nada acrescenta aos elementos sobre os quais há de recair a cognição do juiz, versando sobre questões atinentes aos requisitos da ação executiva e à validade dos atos executivos - ou propriamente de ação de conhecimento - caso a impugnação sirva de veículo a um pedido, em que se postula o reconhecimento de dada situação jurídica e a respectiva atribuição de um bem jurídico ao impugnante. ${ }^{320}$

Mesmo quando a execução é provisória, ao juiz da causa, encarregado de fazer cumprir sua própria sentença, não se permite rever, alterar ou suprimir o que já se acha assentado no decisório exequendo. Nenhum juiz, em regra, decidirá novamente as questões já decididas. $\mathrm{O}$ art. 475-L, neste sentido, enumera de maneira exaustiva as arguições admissíveis na resistência à ordem judicial de cumprimento da sentença.

\footnotetext{
317 THEODORO JR, Humberto. Processo de Execução e Cumprimento da Sentença, cit., p. 584.

${ }^{318}$ MEDINA, José Miguel Garcia; WAMBIER, Luiz Rodrigues; WAMBIER, Teresa Arruda Alvim. Sobre a impugnação..., cit., p. 398/399.

${ }^{319}$ DINAMARCO, Cândido Rangel. Instituições..., vol. IV, cit., p. 747/748.

${ }^{320}$ MEDINA, José Miguel Garcia; WAMBIER, Luiz Rodrigues; WAMBIER, Teresa Arruda Alvim. Sobre a impugnação..., cit., p. 402/403.
} 
Diante dos limites do presente estudo, limitamo-nos a mencioná-las: (i) falta ou nulidade da citação, se o processo correu à revelia; (ii) inexigibilidade do título; (iii) penhora incorreta ou avaliação errônea; (iv) ilegitimidade das partes; (v) excesso de execução; e (vi) qualquer causa impeditiva, modificativa ou extintiva da obrigação. Humberto Theodoro ainda cita duas previsões legais: (vii) inconstitucionalidade da sentença (art. 475-L, § $1^{\circ}$ ); e (viii) nulidade da sentença arbitral (art. 33, § $3^{\circ}$ da Lei $9.307 / 1996$ - lei de arbitragem). ${ }^{321}$

De outra parte, é importante mencionar um método comum de defesa do executado, a chamada exceção de pré-executividade, que admite as matérias que o juiz poderia conhecer de ofício, a qualquer tempo e sem segurança de juízo, não suspendendo a execução e não permitindo dilações probatórias. Segundo Dinamarco, a grande valia desse remédio processual defensivo consiste na capacidade que ele tinha, e os embargos não, de evitar penhoras ilegítimas. Contudo, o autor afirma que com as reformas no sistema executivo, reduziu-se o espaço de utilidade das objeções de pré-executividade (ou de nãoexecutividade), porque tudo quanto nelas se alegaria e pediria poderá ser alegado e pedido, antes da penhora, mediante impugnação ou embargos. ${ }^{322}$

O autor também afirma serem possíveis como meio de defesa do executado a ação cognitiva autônoma - declaratória ou desconstitutiva -, embargos de segunda fase (art. 746 do CPC), embargos de retenção, exceções de incompetência relativa ou de suspensão ou impedimento do juiz, impugnação do valor da causa, incidente de falsidade e, ainda, o poder de que o juiz dispõe para fazer ex officio o controle da justiça e regularidade da execução. $^{323}$

\footnotetext{
321 THEODORO JR, Humberto. Processo de Execução e Cumprimento da Sentença, cit., p. 584/592.

322 DINAMARCO, Cândido Rangel. Instituições..., vol. IV, cit., p. 845/846. Dinamarco sustenta que ainda assim, não se pode excluir, a priori, a admissibilidade dessa via informal, a qual continua admissível sempre que na emergência de uma situação excepcional não seja ainda possível ao executado articular adequadamente uma daquelas oposições à execução. Além disso, permanece íntegra a utilidade das objeções de pré-executividade depois de opostos ou de decorrido in albis o prazo para opor os embargos ou impugnação, nas mesmas circunstâncias de antes (fundamentos diferentes) (p. 846).

${ }^{323}$ DINAMARCO, Cândido Rangel. Instituições..., vol. IV, cit., p. 847.
} 


\section{A CARGA EXECUTIVA DA SENTENÇA CIVIL}

\subsection{A sentença passível de execução}

Diante do que até então foi abordado, é importante analisar, finalmente, a carga executiva da sentença civil no direito processual civil vigente. Conforme discorrido, a Lei Federal 11.232/05 alterou o processo de execução de título judicial do CPC, inserindo a fase do cumprimento de sentença no Livro I do Código - processo de conhecimento. O art. 475-N é o dispositivo que prevê os títulos executivos judiciais no processo civil brasileiro. Disposição semelhante está prevista para o novo Código, ainda em tramitação no Congresso Nacional (Projeto de Lei no 8.046/2010).

Diante da previsão do inciso I do dispositivo mencionado - de que é título executivo judicial a sentença que reconheça a existência de obrigação de fazer, não fazer, entregar coisa ou pagar quantia -, a discussão relevante que surge entre os operadores do direito é se, a partir de então, passou a sentença declaratória, além da condenatória, a ter eficácia executiva, ou seja, também passível de ser considerada título executivo judicial pelo sistema processual, capaz de propiciar a execução.

O que deve ficar claro, a esse respeito, é que não se pretende com isso assumir que toda sentença declaratória tem eficácia executiva, mas somente a que atender ao comando do inc. I do art. 475-N, isto é, que reconheça a existência de obrigação de fazer, não fazer, entregar coisa ou pagar quantia. ${ }^{324}$

A doutrina divide-se entre aqueles que defendem a eficácia executiva da sentença declaratória e os que a negam. Adotando-se a primeira corrente, é necessário compreender a repercussão no sistema processual civil e a consequente modificação da sistemática de execução de sentenças judiciais. Em outras palavras, importa verificar quais os efeitos da assunção da tese de que a sentença declaratória possui - ou pode possuir - eficácia executiva.

${ }^{324}$ Acerca da execução e do cumprimento da sentença, v. Capítulo 2. 
Diante da análise detida dos conceitos e institutos da tutela jurisdicional, da sentença judicial e da execução e do cumprimento da sentença, como mecanismo de resposta estatal às insatisfações no Estado Democrático de Direito, a atribuição de eficácia executiva à sentença declaratória surge para aperfeiçoar o sistema e proporcionar melhor efetividade ao processo civil.

Tal interpretação se coaduna com o ideal da instrumentalidade do processo, que, conforme preconizada por Dinamarco, em seu primeiro sentido conduz à ideia de efetividade do processo, entendida como capacidade de exaurir os objetivos que o legitimam no contexto jurídico-social e político, bem como, em seu segundo sentido, indica a tomada de consciência de que o processo não é um fim em si mesmo e, portanto, as suas regras não têm valor absoluto que sobrepuje as do direito substancial e as exigências sociais de pacificação de conflitos e conflitantes. ${ }^{325}$

No mesmo sentido, Humberto Theodoro Jr afirma que nessa maleabilidade de manejo que as figuras processuais adquiriram no processo efetivo e justo dos novos tempos é que reside a grande riqueza da prestação jurisdicional moderna. Saber fazer uso da abundância dessa fonte de justiça é a virtude por que aspiram os processualistas realmente comprometidos com os novos recursos das garantias constitucionais de tutela jurídica. ${ }^{326}$

Assim, sentença passível de execução, nos termos do art. 162, § $1^{\circ}$ do CPC, pode ser detectada tanto em sentenças definitivas - com resolução de mérito - como em sentenças terminativas - sem apreciação do mérito da causa. Para o citado autor mineiro, o que importa é o julgado conter reconhecimento de alguma prestação a ser cumprida pela parte vencida. $^{327}$

Por outro lado, é de se defender que à sentença meramente declaratória com eficácia executiva não se aplicará a multa coercitiva do art. 475-J do CPC, exatamente porque ainda não foi imposto ao executado o dever de prestar, que foi apenas certificado na sentença. Tendo em vista que tal dispositivo concede o prazo de 15 dias para o condenado

325 DINAMARCO, Cândido Rangel. A instrumentalidade do processo. cit., p. 236. Cita-se a doutrina de Dinamarco, apesar de referido processualista ser contrário à interpretação que se sustenta, conforme ficará mais claro adiante.

326 THEODORO JR, Humberto. Processo de Execução e Cumprimento da Sentença, cit., p. 549.

327 THEODORO JR, Humberto. Processo de Execução e Cumprimento da Sentença, cit., p. 600. 
efetuar o pagamento, sob pena de incidência de multa de $10 \%$ sobre o valor do débito, tal somente poderá ser exigível do obrigado após sua intimação para cumprimento, após provocação da parte interessada.

De outra parte, admitida a eficácia executiva da sentença declaratória, surge, por que não, a dúvida acerca da possível eficácia executiva da sentença constitutiva. Essa questão, diferentemente da primeira, não é amplamente discutida na doutrina e na jurisprudência.

A respeito, Humberto Theodoro Jr afirma que, para autorizar execução, não se deve considerar sentença condenatória apenas a conferida na ação de igual nome. Segundo o processualista, a parte dispositiva de todas as sentenças, inclusive as declaratórias e constitutivas, contém sempre provimentos de condenação relativos aos encargos processuais. Além disso, as sentenças declaratórias e constitutivas que não configuram título executivo são, na verdade, aquelas que se limitam a declarar ou constituir uma situação jurídica sem acertar prestação a ser cumprida por um dos litigantes em favor do outro, sendo, pois, as sentenças puramente declaratórias ou puramente constitutivas. ${ }^{328}$

Didier Jr, Cunha, Braga e Oliveira afirmam que a sentença constitutiva também pode servir como título executivo. Segundo referidos autores, o que dispensa execução no caso da sentença constitutiva, na verdade, é o direito potestativo reconhecido na sentença, e não ela mesma. ${ }^{329}$ Neste sentido, a efetivação de um direito potestativo pode gerar um direito a uma prestação, isto é, a situação jurídica criada após a efetivação de um direito potestativo pode ser exatamente um direito ao uma prestação de fazer, não fazer ou dar.

Direitos a uma prestação, que surjam da efetivação de um direito potestativo, são, portanto, reconhecidos por uma sentença constitutiva: ao certificar e efetivar um direito

\footnotetext{
328 THEODORO JR, Humberto. Processo de Execução e Cumprimento da Sentença, cit., p. 599. O autor ainda cita o caso de pedidos múltiplos e consequentes, nos quais pode ocorrer sentença mista, como aquelas que, numa só decisão, resolvem ou anulam contrato e condenam o vencido a restituir o bem negociado. $\mathrm{O}$ provimento constitutivo não reclama execução, mas a decisão de mandar devolver o objeto do contrato é tipicamente de condenação e poderá ensejar execução forçada.

${ }^{329}$ DIDIER JR., Fredie; CUNHA, Leonardo Carneiro da; BRAGA, Paula Sarno; OLIVEIRA, Rafael. ob. cit., p. 163/164. O conteúdo da sentença constitutiva consiste no reconhecimento e na efetivação de um direito potestativo, o qual não se relaciona a qualquer prestação do sujeito passivo. Em razão disso, o direito não pode e nem precisa ser executado, no sentido de serem praticados atos materiais consistentes na efetivação de uma prestação devida (conduta humana devida), de resto inexistente neste vínculo jurídico. A respeito, v. Capítulo 2.
} 
potestativo, o órgão jurisdicional certifica, também, por consequência, o direito a uma prestação que daquele é consequência. ${ }^{330} \mathrm{E}$ várias são as possibilidades que podem, na prática, resultar na aplicação dessa premissa, como a decisão que rescinde uma sentença que já fora executada - que é indiscutivelmente constitutiva - gera, por efeito anexo, o direito do executado à indenização pelo exequente dos prejuízos que lhe foram causados em razão da execução malsinada. ${ }^{331}$

Os citados autores ainda preconizam que a hipótese do art. 475-N, I do CPC constitui um tipo legal aberto, operando-se no modo tipológico-comparativo e funcionando com base na semelhança, de sorte que se revelam amplos os casos enquadráveis na definição legal. ${ }^{332}$ Com a redação do dispositivo, inclusive as decisões interlocutórias podem ser título executivo judicial: a execução pode ser provisória, como no caso da tutela antecipada, ou definitiva, se se tratar de decisão interlocutória de mérito para os que aceitam a tese da sentença parcial $^{333}$. Assim, para que uma decisão interlocutória seja título executivo, basta que reconheça, ainda que provisoriamente, a existência de um dever de prestar. ${ }^{334}$

Marcelo Abelha, por sua vez, sustenta que a palavra sentença do dispositivo deve ser empregada para designar todo e qualquer provimento judicial - decisão interlocutória, sentença e acórdão - que imponha ao sujeito processual o cumprimento de uma prestação de dar, fazer ou não fazer. Aqui se incluem tanto os provimentos judiciais que pretendam debelar crises jurídicas de cooperação - adimplemento ou descumprimento - como aqueles outros que são impostos na condenação por má-fé processual, os relativos aos honorários advocatícios, enfim, qualquer provimento judicial que imponha uma prestação no curso do processo. $^{335}$

\footnotetext{
${ }^{330}$ DIDIER JR., Fredie; CUNHA, Leonardo Carneiro da; BRAGA, Paula Sarno; OLIVEIRA, Rafael. ob. cit., p. 164.

${ }^{331}$ DIDIER JR., Fredie; CUNHA, Leonardo Carneiro da; BRAGA, Paula Sarno; OLIVEIRA, Rafael. ob. cit., p. 165. Essa decisão tem aptidão para transformar-se em título executivo, pois torna certa a obrigação de indenizar, que, não obstante, ainda é ilíquida, se impondo a apuração da extensão do prejuízo em liquidação. Os autores ainda citam outros exemplos de sentenças constitutivas que impõem uma prestação passível de execução (ob. cit., p. 165/166).

${ }^{332}$ Ob. cit., p. 167.

${ }^{333}$ A esse respeito, v. item 1.2.2.1.

${ }^{334}$ A esse respeito, v. item 2.4.1 no ponto sobre decisão interlocutória como título executivo judicial

${ }^{335}$ RODRIGUES, Marcelo Abelha. Manual de execução civil. cit., p. 127.
} 
O professor capixaba registra, ainda, que pouco importa qual será a técnica processual criada pelo legislador e aplicada pelo juiz no caso concreto para efetivar o provimento que imponha a prestação devida, ou seja, pode ser a "mandamental, a executiva lato sensu ou a monitória, ou qualquer outro nome que se queira dar", o que importa é que isso não altera o caráter executivo do referido provimento, que revela a norma concreta e precisa ser atuado em concreto para debelar a pretensão insatisfeita. ${ }^{336}$

Didier Jr, Cunha, Braga e Oliveira ainda atribuem outra modificação à previsão do art. 475-N, I do CPC: indiscutivelmente havia títulos executivos judiciais que não estavam compreendidos na dicção legal do art. 584, I, que fazia menção expressa à sentença condenatória, exatamente porque não eram condenatórios. Citem-se os casos da sentença que homologa reconhecimento de procedência do pedido, sentença que extingue a execução provisória, e que gera o dever de indenizar, sentença que extingue o processo cautelar e gera o dever de indenizar e a sentença em ação de oferta de alimentos e consignação em pagamento, de conteúdo meramente declaratório. Neste sentido, o texto atual não dá margem a essa controvérsia. ${ }^{337}$

Por outro lado, Teori Albino Zavascki já sustentava antes mesmo da Lei 11.232/05 que preferia enfrentar o problema da executividade das sentenças sob o enfoque metodologicamente mais adequado à definição que adota de título executivo. O importante nesse domínio jurídico, segundo o processualista, não está em qualificar a sentença como condenatória ou não, mas em identificar, em seu conteúdo, os elementos que conferem a ela a aptidão para servir de base à execução forçada. E o CPC conforta, sistematicamente, a afirmação de que a executividade é característica de sentenças que trazem em si a identificação integral de uma norma jurídica concreta, com prestação exigível de dar, fazer, não fazer ou pagar quantia. ${ }^{338}$

\footnotetext{
${ }^{336}$ RODRIGUES, Marcelo Abelha. Manual de execução civil. cit., p. 127.

${ }^{337}$ DIDIER JR., Fredie; CUNHA, Leonardo Carneiro da; BRAGA, Paula Sarno; OLIVEIRA, Rafael. ob. cit., p. $166 / 167$.

${ }^{338}$ ZAVASCKI, Teori Albino. Processo de execução: parte geral, cit., p. 309. O autor exemplifica citando os seguintes casos: a) a de que trata o art. 76 quando, ao julgar a denunciação da lide, o juiz declara conforme o caso, o direito do evicto, ou a responsabilidade por perdas e danos; b) a de que trata o $\S 2^{\circ}$ do art. 899, que julga a ação consignatória em que o depósito oferecido pelo autor foi insuficiente, propiciando que o juiz determine o montante da insuficiência ainda devido pelo autor (sentença que constituirá título executivo em favor do réu); c) a de que trata o art. 918, quando, ao decidir ação de prestação de contas, o juiz declara, na sentença, o montante de saldo credor (que pode favorecer o autor ou o réu).

O processualista afirma ainda que são também títulos que ensejam execução forçada as sentenças que extinguem a execução provisória, das quais decorre, automaticamente, independentemente de condenação, a
} 
Por tal motivo que se retoma conclusão alcançada acima nos itens 1.2.3 e 2.4.1, no sentido de que a distinção entre as sentenças condenatórias, constitutivas e declaratórias ou ainda, para aqueles que adotam a teoria quinária, as mandamentais e executivas - deixa de ser relevante sob o ponto de vista executivo, na medida em que, independentemente do "rótulo" que se dê, tal sentença será título executivo judicial se contiver reconhecimento da existência de obrigação de fazer, não fazer, entregar coisa ou pagar quantia, nos termos do art. 475-N, inc. I.

\subsection{Atribuição de eficácia executiva à sentença declaratória}

A principal consequência, portanto, que se discute da previsão do art. 475-N, inciso I do Código é a atribuição de eficácia executiva às sentenças declaratórias. A locução sentença condenatória foi substituída por "sentença proferida no processo civil, que reconheça a existência de obrigação de fazer, não-fazer, entregar coisa ou pagar quantia”.

Repita-se, a esse respeito, que a extensão da eficácia executiva à sentença meramente declaratória constituía proposta aventada antes mesmo do advento da lei 11.232/05. Teori Albino Zavascki, que é estudioso do processo e ministro do Superior Tribunal de Justiça, defendia tal possibilidade com a previsão original do Código de 1973, que não atribuía à sentença declaratória, mas somente expressamente à condenatória, a qualidade de título executivo. ${ }^{339}$

Ressalte-se que o Código de 1939 previa no artigo 290 que na ação declaratória, a sentença que passar em julgado valerá como preceito, mas a execução do que houver sido declarado somente poderá promover-se em virtude de sentença condenatória. Contudo, o

responsabilidade do exequente pelos danos causados, nos termos do art. 588, inc. I do CPC (na redação anterior à Lei 11.232/05). Da mesma forma, nas situações previstas no art. 811 do CPC, nasce a executividade, independentemente de condenação, de provimentos jurisdicionais que produzem a ineficácia das medidas cautelares e das quais decorre, como consequência natural da ordem jurídica, a responsabilidade objetiva do requerente pelos prejuízos causados ao requerido. Outro exemplo, ainda, é a sentença que julga procedente a ação de resilição de contrato de promessa de compra e venda, que segundo a jurisprudência do STF, reafirmada pelo STJ, em casos tais, a sentença é título apto a sustentar, desde logo, a pretensão à tutela executiva visando a entrega da coisa, independentemente de ter havido pedido explícito ou condenação específica a respeito, pois a obrigação de restituir o bem é efeito necessário e natural da resolução do compromisso (ob. cit., p. 310).

${ }^{339}$ ZAVASCKI, Teori Albino. Processo de execução, cit., p. 312. 
Código de 1973, no parágrafo único do art. $4^{\circ}$, permite a ação declaratória, ainda que tenha ocorrido a violação do direito.

Ora, não parece razoável que após toda a tramitação do processo para reconhecimento da obrigação seja o autor obrigado a uma vez mais provocar o Judiciário através de novo processo de conhecimento, agora para adquirir sentença condenatória em seu favor. ${ }^{340}$

No entanto, parte importante da doutrina se posiciona pela inexistência de eficácia executiva da sentença declaratória. Um dos mais importantes processualistas brasileiros, Cândido Rangel Dinamarco afirma que a redação do inciso I do art. 475-N do CPC causa a impressão de que no direito positivo brasileiro atual o título executivo por excelência não seja mais somente a sentença condenatória, mas também a meramente declaratória.

\footnotetext{
${ }^{340}$ ZAVASCKI, Teori Albino. Processo de execução, cit., p. 312. Assim prossegue o autor, no trabalho doutrinário anterior à lei 11.232/05, sobre a previsão do art. $4^{\circ}$, p. ú.: "Ao assim estabelecer, dá ensejo a que a sentença, agora, possa em juízo, não apenas sobre o preceito da endonorma (mandado primário ainda não transgredido), mas também sobre o da perinorma (mandado sancionatório), permitindo juízo de definição inclusive a respeito da exigibilidade da prestação devida. Isso representa, sem dúvida, um comprometimento do padrão clássico de tutela puramente declaratória (como tutela tipicamente preventiva), circunstância que não pode ser desconsiderada pelo interprete do Código.

Assim considerando, pode-se sustentar que, em nosso atual sistema, quando a sentença, proferida em ação declaratória, trouxer definição de certeza a respeito, não apenas da existência da relação jurídica, mas também da exigibilidade da prestação devida, mas também da exigibilidade da prestação devida, não haverá razão alguma, lógica ou jurídica, para negar-lhe imediata executividade. Pelo contrário: seria inconstitucional, como antes se fez ver, o dispositivo de lei ordinária que negasse força executiva a sentença com esse conteúdo. A executividade, na espécie, decorre do próprio sistema, o que torna desnecessária qualquer menção expressa no art. 584 do Código. E sendo assim, a inovação introduzida pelo parágrafo único do art. $4^{\circ}$ do CPC nem sempre poderia ter convivência harmônica com o art. 290 do Código anterior, razão pela qual foi adequada e coerente a não reprodução deste último pelo legislador de 1973.

Interpretação sistemática do Código, especialmente depois das reformas que lhe foram impostas a partir de 1994, permite que se vá mais longe. Imagine sentença que, em ação declaratória, defina, com força de coisa julgada, que a entrega de certa quantia de Pedro para Paulo foi a título de mútuo, e não de doação, e que o prazo para devolvê-la deve ocorrer (ou já ocorreu) em determinada data; ou que a ocupação do imóvel de Joana por Maria não é a título de comodato, mas de locação, e que o valor mensal do aluguel é de $R \$ 300,00$, pagáveis no dia 30 de cada mês. Há, em tal sentença, como se percebe, definição de norma jurídica individualizada, contendo obrigação de pagar quantia certa. Se a definição dessa mesma norma estivesse representada em documento particular assinado pelas partes e por duas testemunhas, ela constituiria título executivo, nos termos do inciso II, do art. 585, do CPC. Igualmente, se a definição decorresse de documento firmado perante tabelião. Também teria força executiva se tivesse sido definida por autocomposição (transação) referendada pelo Ministério Público, ou pela Defensoria Pública ou, ainda, pelos advogados dos transatores. Ora, nos exemplos dados, a norma individualizada e a relação jurídica correspondente têm grau de certeza muito mais elevado: é certeza definida em processo de que participaram não apenas os demandantes, mas também os seus advogados, e, sobretudo, o próprio Estado-juiz, dando ao ato a marca da oficialidade. Nessas circunstâncias, negar força de título executivo a esta espécie de sentença seria atentar contra o sistema processual, sua lógica e os valores nele consagrados" (ob. cit., p. 312/313).
} 
Essa nova redação, para referido jurista, não alterou a situação anterior ao menos em razão de uma gravíssima irregularidade no processo legislativo que a gerou. Isso, porque o texto originário do projeto aprovado pela Câmara dos Deputados consignava a locução sentença condenatória e foi somente no Senado Federal que uma emenda introduziu a nova redação, a qual deveria obrigatoriamente ser objeto de votação ulterior pela Câmara, nos termos do art. 65, parágrafo único da Constituição Federal, mas não o foi. $^{341342}$

Diante disso, Dinamarco sustenta que ou a emenda é inconstitucional, por violar o bicameralismo - o que a impediria de ingressar eficazmente na ordem jurídica -, ou essa foi somente emenda de redação e, portanto, não alterou o significado e a extensão da disposição que estava no projeto, devendo-se ler o dispositivo como estava antes, isto é, como se dissesse simplesmente sentença condenatória. ${ }^{343}$

O Código de processo civil comentado por Nelson Nery Jr e Rosa Maria de Andrade Nery igualmente conclui pela inconstitucionalidade do referido dispositivo, sugerindo que o texto que deve ser aplicado pelos operadores do direito é no sentido de que somente a sentença condenatória possui eficácia executiva. ${ }^{344}$

A esse respeito, é importante mencionar que ao chegar no Senado Federal, foram apresentadas quinze emendas ao projeto de lei 3.253/2004, que no Senado se tornou PLC 52/2004, o qual resultou na Lei 11.232/05. As emendas foram de autoria conjunta dos senadores Arthur Virgílio e Antero Paes de Barros, sendo a emenda de $n^{\circ} 2$ a relativa à redação do art. 475-N, I. ${ }^{345}$

\footnotetext{
${ }^{341}$ DINAMARCO, Cândido Rangel. Instituições..., vol. IV, cit., p. 246/247.

${ }^{342}$ Art. 65. O projeto de lei aprovado por uma Casa será revisto pela outra, em um só turno de discussão e votação, e enviado à sanção ou promulgação, se a Casa revisora o aprovar, ou arquivado, se o rejeitar.

Parágrafo único. Sendo o projeto emendado, voltará à Casa iniciadora.

${ }^{343}$ DINAMARCO, Cândido Rangel. Instituições..., vol. IV, cit., p. 248.

${ }^{344}$ Cf. NERY JR., Nelson; NERY, Rosa Maria de Andrade. Código de processo civil comentado e legislação extravagante, cit., nota I: 5 e 6, p. 780.

${ }^{345} \mathrm{O}$ texto previa: "a manutenção do termo condenatória no inc. I do art. 475- $N$, tal como atualmente consta do PLC 52/2004, para referir-se às sentenças relacionadas a um direito de prestação, afigura-se inconveniente, mas apenas de apontar uma incoerência do processo reformista. O art. 287 do CPC foi recentemente alterado pela Lei 10.444/2002, para, entre outras mudanças, retirar a palavra condenação que estava contida em seu texto".
} 
O Senador Relator Antonio Carlos Valadares, em sua justificativa, asseverou que devia-se extinguir a previsão de sentença condenatória no mencionado dispositivo, "até porque, conforme recente decisão do STJ (REsp 588202/PR), admite-se a eficácia executiva de decisões declaratórias", com o que também se contemplaria a Emenda 2. ${ }^{346}$

Dessa forma, nos parece que a redação dada pelo Senado ao dispositivo, sob o ponto de vista da mens legislatoris, não inovou no ordenamento jurídico, na medida em que admitia a possibilidade de execução de sentença declaratória, o que ficou claramente reconhecido na justificativa. Em outras palavras, o próprio processo legislativo considerou que já eram executivas as sentenças declaratórias, antes da alteração da redação do dispositivo no Senado.

Dinamarco prossegue sua crítica afirmando que atribuir eficácia executiva à sentença declaratória choca-se com tradição solidamente arraigada na legislação brasileira, com os modelos histórica e internacionalmente aceitos no mundo jurídico-processual de raízes romano-germânicas e, sobretudo, com o próprio sistema do CPC como um todo. ${ }^{347}$ A eliminação da diferença entre a eficácia da sentença condenatória e da meramente declaratória, portanto, deixaria sem significado racional o art. $4^{\circ}$, parágrafo único do CPC, onde se estabelece clara distinção entre os dois pólos do binômio declaraçãocondenação. $^{348}$

Por fim, Dinamarco afirma que o CPC sempre empregou e mesmo depois das reformas continua a empregar em dezenas de dispositivos o vocábulo condenação, o verbo condenar e o adjetivo condenatório, o que demonstraria que a limitação da executividade a essa espécie de sentenças integra o sistema como um todo, não se legitimando interpretações destoantes deste.

De outra parte, o processualista gaúcho Araken de Assis sustenta que o art. 475-N, I, ao abandonar o adjetivo condenatório e empregar a expressão analítica que reconheça $a$

\footnotetext{
${ }^{346}$ PALHARES, Cinara. A sentença cível como título executivo judicial, cit., p. 99.

${ }^{347}$ DINAMARCO, Cândido Rangel. Instituições..., vol. IV, cit., p. 247.

${ }^{348}$ DINAMARCO, Cândido Rangel. Instituições..., vol. IV, cit., p. 247. O autor sugere que se a lei oferece a possibilidade de propor a ação meramente declaratória quando a situação estiver madura para a condenatória (interesse de agir - art. $4^{\circ}$, parágrafo), autorizando a opção do autor, não haveria como explicar que, havendo ele feito sua opção, ainda assim a sentença que pediu (meramente declaratória) terá a mesma eficácia daquela que preferiu não pedir (condenatória). Assim, o título executivo continua sendo somente a sentença condenatória proferida no processo civil (ob. cit., p. 247/248).
} 
existência de obrigação a tais pronunciamentos, não inovou substancialmente, mas limitou o campo de incidência da execução, reservando cumprimento aos pronunciamentos mandamental e executivo. De um lado, os elementos declaratório e constitutivo não comportam execução, pois já entregam por si mesmos os respectivos bens da vida ao vitorioso - certeza e estado jurídico novo, respectivamente. E o reconhecimento da existência de obrigação, de acordo com o processualista, é mais do que declarar a relação jurídica: dá-se um passo adiante e já se condena o réu, possibilitando a execução. ${ }^{349} 350$

Luiz Guilherme Marinoni e Sérgio Cruz Arenhart, por sua vez, afirmam que a sentença que reconhece obrigação de pagar ainda apenas condena, ou melhor, impõe a sanção executiva, abrindo oportunidade para o requerimento de execução ou de penhora de bens do devedor. Ao contrário, as sentenças que reconhecem obrigações de não fazer, fazer ou de entregar coisa contêm as modalidades executivas idôneas à tutela do direito material. A sentença que reconhece obrigação de pagar quantia apenas autoriza o requerimento dos meios de execução, enquanto as sentenças que reconhecem as obrigações de não fazer, fazer ou de entregar coisa têm executividade intrínseca.

Neste sentido, segundo os mencionados doutrinadores, há evidente distinção entre a sentença que reconhece obrigação de pagar quantia, de um lado, e as sentenças que reconhecem as obrigações de não fazer, fazer ou de entregar coisa, de outro: a sentença que reconhece obrigação de pagar quantia continua a não ter qualquer conteúdo

\footnotetext{
${ }^{349}$ E assim conclui: "Quando se afirma que há execução baseada em sentença declaratória - por exemplo, o órgão judiciário 'declarou' que Pedro deve ' $x$ ' a João -, incorre-se em erro crasso, olvidando que nenhum provimento é 'puro' $e$, no exemplo aventado, o juiz foi além da simples declaração, emitindo pronunciamento condenatório, porque reconheceu o inadimplemento. Na verdade, o enunciado relaciona-se com a conhecida teoria que divisa na condenação uma dupla declaração, impondo a segunda um prestação ao vencido. Sentença declarativa é exeqüível somente quanto à sucumbência. A 'execução' (ou cumprimento) dos provimentos de força mandamental (v.g., mandado de segurança) e executiva (v.g., despejo) se subordinam, fundamentalmente, às disposições das leis especiais que contemplam sua execução incidental e, no caso de ações atípicas, às disposições dos arts. 461 e 461-A, conforme dispõe o art. 475-I, caput. Assim, a explicitação do art. 475-N, I, relativamente ao reconhecimento da existência de 'obrigação de fazer, não fazer, entregar coisa ou pagar quantia', introduzida no curso do processo legislativo, reclama interpretação sistemática e à luz do art. 475-I, caput. Aliás, o art. 475-J, caput, impõe o prazo de espera e a multa subseqüente ao vencido 'condenado ao pagamento de quantia certa ou já liquidada', revelando que, na verdade, o art. 475-N, I, cuida de condenação..." (ASSIS, Araken de. Cumprimento da Sentença. $3^{\mathrm{a}}$ Ed., Rio de Janeiro: Forense, 2010, p. 157/158).

${ }^{350}$ Em outro artigo sobre o assunto, Araken de Assis também afirma que, por outro lado, continua em vigor o art. $4^{\circ}$, parágrafo único do $\mathrm{CPC}$, segundo o qual, violado o direito, o interesse do autor pode se limitar à declaração da responsabilidade. Equiparar as duas situações, para o autor, infringe, claramente, esta última disposição, subtraindo ao autor de pleitear a providência que lhe convém, desinteressado da (impossível) futura execução. Por fim, menciona e corrobora a posição de Cassio Scarpinella Bueno (A nova etapa da reforma do Código de Processo Civil, v. 1, n. 16.1, p. 135-136) que entende que a sentença do art. 475-N, I é a sentença condenatória (ASSIS, Araken de. Sentença..., cit., p. 19).
} 
executivo, ao contrário do que acontece com as outras duas, que fazem das modalidades de execução componentes essenciais de suas feições. ${ }^{351}$ Para os autores há uma confusão entre sentença declaratória e sentença dependente de execução, resultado da ignorância da distinção entre sentença e tutela do direito, o que demonstra a necessidade de se compreender o processo civil a partir da teoria da tutela de direitos. ${ }^{352}$

Cassio Scarpinella Bueno, por seu turno, sustenta que a melhor interpretação a ser dada ao inc. I do art. 475-N é a de que o título executivo previsto pela regra é o das sentenças que reconheçam suficientemente o inadimplemento - e não a mera existência - de uma obrigação de fazer, não fazer, entregar coisa ou pagar quantia. Por isso mesmo, independentemente do nome que ela tenha - se condenatória ou executiva lato sensu ou mandamental ou, até mesmo, se declaratória ou constitutiva - deve-se admitir a prática de atos executivos voltados à satisfação daquele inadimplemento. 353354355

${ }^{351}$ MARINONI, Luiz Guilherme; ARENHART, Sérgio Cruz. Curso de processo civil, volume 3: execução. cit., p. 115/116.

352 MARINONI, Luiz Guilherme; ARENHART, Sérgio Cruz. Curso de processo civil, volume 3: execução, cit., p. 63. Neste sentido, sentença é uma técnica processual destinada à prestação da tutela jurisdicional do direito. A tutela jurisdicional do direito que não pode ser prestada pela técnica da sentença declaratória, por necessitar de meios de execução, obviamente não é uma tutela declaratória. A tutela que necessita de fazer, não fazer, entrega de coisa ou pagamento de quantia é uma tutela que não é prestada por uma sentença que basta por si só, uma vez que exige meios de execução.

353 BUENO, Cassio Scarpinella. Curso Sistematizado de Direito Processual Civil: Tutela Jurisdicional Executiva, vol. 3. São Paulo: Saraiva, 2008, p. 82. A redação proposta para o novo CPC contempla expressamente a necessidade de reconhecimento da exigibilidade da obrigação, e não somente da existência dela, para que a sentença seja título executivo judicial (conforme art. 502, inc. I do Substitutivo ao PL 166/2010 aprovado no Senado em dezembro de 2010, sob n. 8.046/10 na Câmara).

${ }^{354} \mathrm{Na}$ nota 45 da página 160 da obra de DIDIER JR., Fredie; CUNHA, Leonardo Carneiro da; BRAGA, Paula Sarno; OLIVEIRA, Rafael, os autores mencionam doutrina que se manifestou contrária à atribuição de eficácia executiva da sentença declaratória, tais como Araken de Assis e "CÂMARA, Alexandre Freitas. $A$ nova execução de sentença. Rio de Janeiro: Lumen Juris, 2006, p. 92-98; WAMBIER, Luiz Rodrigues, ALMEIDA, Flávio Renato Correia, e TALAMINI, Eduardo. Curso avançado de processo civil. 8 ed. São Paulo: RT, 2006, v. 2, p. 56-58; GRINOVER, Ada Pellegrini. 'Cumprimento da sentença'. A nova execução de títulos judiciais - comentários à Lei 11.232/05. Sérgio Renault e Pierpaolo Bottini (coord.). São Paulo: Saraiva, 2006, p. 125-126".

355 Cinara Palhares também se manifesta contrária à eficácia executiva da sentença declaratória, partindo da análise do art. $4^{\circ}$ do CPC, no sentido de que a pretensão da parte quando do ajuizamento da ação teria sido somente a certeza sobre a existência do direito. A autora afirma que se a simples declaração não se mostrar apta a solucionar o conflito de interesses, a demanda deverá ser condenatória. Além disso, sustenta a inconstitucionalidade do dispositivo, conforme acima analisado (PALHARES, Cinara. A sentença cível como título executivo judicial-Considerações sobre o art. 475-N, I, do CPC, cit., passim).

Referida acadêmica reúne sistematicamente todos os argumentos que são suscitados pelos defensores da eficácia executiva da sentença declaratória: $1^{\circ}$ ) a interpretação literal do art. 475-N, I, favorece essa compreensão, já que se refere à sentença que reconheça a existência de obrigação, sendo que a declaração de existência de relação jurídica sempre foi conceito ligado à sentença declaratória; $2^{\circ}$ ) a lei pode eregir à categoria de título executivo qualquer fenômeno que se ligue à pretensão executiva, e, sendo título judicial, o fato deve assegurar suficiente certeza acerca da existência do direito, o que ocorre com a sentença declaratória; $3^{\circ}$ ) não há monopólio da executividade das sentenças condenatórias, pois o rol dos títulos executivos judiciais inclui sentenças em que não há ordem ao vencido para qualquer tipo concreto de prestação (sentença penal condenatória, formal de partilha), sendo que, nesses casos, o efeito executivo e 
Neste sentido, o processualista afirma que a fórmula redacional do dispositivo deve ser entendida como a da sentença condenatória, entendida esta como a sentença que não seja meramente declaratória e a que não seja constitutiva. Quaisquer outras, justamente porque reconhecem que a obrigação não foi cumprida como deveria ter sido e que impõe o seu cumprimento, são a sentença a que se refere o inciso I do art. 475-N. Assumir o entendimento de o dispositivo abrange também outras sentenças que não as condenatórias, para referido autor, é um despropósito sem tamanho, cujas consequências são desastrosas em todos os sentidos e têm o condão de colocar em risco muitos dos avanços da lei $11.232 / 05 .^{356}$

Com o devido respeito aos ilustres processualistas citados, estamos de acordo com a outra parte da doutrina, da qual faz parte Humberto Theodoro Junior ${ }^{357}$, que sustenta a tese de que a sentença declaratória passou a ter eficácia executiva com a redação dada ao art. 475-N, I, pela Lei 11.232/05.

Segundo o mencionado autor mineiro, alargou-se a força executiva das sentenças para além dos tradicionais julgados de condenação, acolhendo corrente doutrinária e jurisprudencial que, mesmo antes da reforma do CPC, já vinha reconhecendo possibilidade, em certos casos, de instaurar execução por quantia certa também com base em sentenças declaratórias. ${ }^{358}$

Isso, porque frestas se abriam já no antigo texto do CPC, fragilizando a teoria de que apenas as sentenças condenatórias produziam título executivo. $\mathrm{O}$ art. 584 incluía no rol

secundário; $4^{\circ}$ ) caso a sentença declaratória contenha todos os elementos da obrigação, mas não faça referência ao valor devido, poderá ser submetida à liquidação, assim como ocorre com a sentença condenatória; $5^{\circ}$ ) seria perda de tempo, em prejuízo das partes e da própria justiça, exigir a abertura de outro processo apenas para tornar a obrigação reconhecida exigível, sendo que as reformas do processo civil são no sentido de dar maior efetividade à prestação jurisdicional; $6^{\circ}$ ) a ação declaratória, pelo art. $4^{\circ}$, parágrafo único do CPC, é cabível até mesmo depois de a obrigação ser exigível; logo, se a ação declaratória trouxer certeza não só quanto à relação jurídica, mas também quanto à exigibilidade, ela terá eficácia executiva; $7^{\circ}$ ) já havia na jurisprudência julgados no sentido de que a sentença declaratória, que contém todos os elementos da obrigação, configura título executivo (RESP 588.202/PR e 502.618/RS). A autora os rebate com base nos argumentos acima expostos, para afirmar a impossibilidade de atribuir eficácia executiva à sentença declaratória. (ob. cit., p. 95/96).

356 BUENO, Cassio Scarpinella. A nova etapa da reforma do Código de Processo Civil: comentários sistemáticos às Leis $n$. 11.187, de 19-10-2005, e 11.232, de 22-12-2005, vol. 1, $2^{\mathrm{a}}$ ed. rev., atual. e ampl., São Paulo: Saraiva, 2006, p. 160/166.

${ }^{357}$ THEODORO JR, Humberto. Curso de Direito Processual Civil - Processo de Execução e Cumprimento da Sentença, Processo Cautelar e Tutela de Urgência. 43 ${ }^{\mathrm{a}}$ Ed., Rio de Janeiro: Forense, 2008, p. 20.

${ }^{358}$ THEODORO JR, Humberto. Curso..., cit., p. 20. 
dos títulos executivos judiciais sentenças em que, de forma alguma, o juiz cogitara de ordenar ao vencido qualquer tipo concreto de prestação. Além disso, o autor elenca dois outros fatores contribuíram para a doutrina fragilizar, ainda mais, a pretensa exclusividade outrora reconhecida à sentença de condenação.

O primeiro é de que a ação declaratória, pelo art. $4^{\circ}$, parágrafo único, do CPC de 1973, passou a ser cabível até mesmo depois de a obrigação ser exigível, isto é, assegurouse o acesso da parte à declaração de seu direito, quando já era possível reclamar o adimplemento do obrigado por via de provimento condenatório.

$\mathrm{O}$ segundo é que nos últimos anos do século $\mathrm{XX}$, o CPC passou por uma série de reformas, todas preocupadas com a melhor e mais efetiva prestação jurisdicional. Boa parte das inovações ocorreram no terreno da execução forçada, tendo como objetivo eliminar entraves burocráticos à rápida satisfação do direito do credor, e ainda, facilitar o seu acesso ao processo executivo. Teria surgido, aí, o momento propício para rever a doutrina clássica que a sentença declaratória nunca poderia ser utilizada como título executivo. ${ }^{359}$

A esse respeito, ainda prossegue Humberto Theodoro Junior que se nosso direito processual caminha para a outorga de força de título executivo a todo e qualquer documento particular em que se retrate obrigação líquida, certa e exigível, por que não se reconhecer igual autoridade à sentença declaratória? Esta, segundo o autor, mais do que qualquer instrumento particular, tem a inconteste autoridade para acertar e positivar a existência de obrigação líquida, certa e exigível. ${ }^{360}$

Athos Gusmão Carneiro, por sua vez, ao comentar a alteração da redação pelo Senado, afirma que, ao fim e ao cabo, a modificação resultou vantajosa, tendo vindo ao encontro dos melhores propósitos de celeridade e de eficiência processual, "eis que, conforme conceituados processualistas já vinham preconizando, conferiu eficácia

\footnotetext{
${ }^{359}$ THEODORO JR, Humberto. Curso..., cit., p. 20/21.

360 THEODORO JR, Humberto. Curso..., cit., p. 22. O autor manifesta a mesma opinião em As vias de execução..., cit., p. 321/322 e em Processo de Execução e Cumprimento da Sentença, cit., p. 601. Afirma que seria pura perda de tempo exigir, em prejuízo das partes e da própria Justiça, a abertura de procedimento condenatório em tais circunstâncias. Se o credor está isento da ação condenatória, bastando dispor de instrumento particular para acertar-lhe o crédito descumprido pelo devedor inadimplente, melhor será sua situação de acesso à execução quanto estiver aparelhado com prévia sentença declaratória onde se ateste a existência de dívida líquida e já vencida.
} 
executiva também à sentença declaratória". ${ }^{361} \mathrm{O}$ autor ainda questiona "por que exigir de Mário, apenas por 'amor aos princípios', a propositura de demorada ação de conhecimento, buscando obter uma segunda sentença, a qual dirá a mesma coisa apenas com o atributo formal da expressa eficácia 'condenatória'?". 362

Teori Albino Zavascki, conforme exposto acima, em estudo doutrinário sobre as sentenças declaratórias, reafirmou o posicionamento que já mantinha desde antes das alterações trazidas pela Lei $\mathrm{n}^{\circ} 11232 / 2005$, no sentido de que se a sentença traz definição de certeza a respeito, não apenas da existência da relação jurídica, mas também da exigibilidade da prestação devida, não há como negar-lhe, categoricamente, eficácia executiva. ${ }^{363} 364$

Marcelo Abelha, ainda que assumindo que seriam raras as hipóteses em que, ao invés de ter ajuizado uma demanda condenatória, o autor pretenda obter uma declaração de existência da relação jurídica obrigacional - e ali mesmo estão contidos todos os elementos que, em tese, permitiriam uma execução caso a sentença fosse impondo uma condenação -, sustenta que esse provimento declaratório pode ser título executivo ou a ele pode ser emprestada a mesma eficácia executiva. Isto, porque a eficácia executiva que é atribuída aos provimentos de prestação poderia ser, por lei, estendida aos provimentos declaratórios que estamparem todos os elementos da obrigação. ${ }^{365}$

\footnotetext{
${ }^{361}$ CARNEIRO, Athos Gusmão. Do 'cumprimento da sentença'..., cit., p. 79.

${ }^{362}$ CARNEIRO, Athos Gusmão. Do 'cumprimento da sentença'..., cit., p. 79.

${ }^{363}$ ZAVASCKI, Teori Albino. Sentenças Declaratórias, Sentenças Condenatórias e Eficácia Executiva dos Julgados. In Repro 109, p. 52. Prossegue o processualista: "ao legislador ordinário não é dado negar executividade à norma jurídica concreta, certificada por sentença, se nela estiverem presentes todos os elementos identificadores da obrigação (sujeitos, prestação, liquidez, exigibilidade), pois isso representaria atentado ao direito constitucional à tutela executiva, que é inerente e complemento necessário do direito de ação. Tutela que se limitasse à cognição, sem medidas complementares para ajustar os fatos ao direito declarado na sentença, seria tutela incompleta. E, se norma jurídica individualizada está definida, de modo completo, por sentença, não há razão alguma, lógica ou jurídica, para submetê-la, novamente, a juízo de certificação, até porque a nova sentença não poderia chegar a resultado diferente da anterior, sob pena de comprometimento da garantia da coisa julgada, assegurada constitucionalmente. Instaurar a cognição sem oferecer às partes e principalmente ao juiz outra alternativa de resultado que não um já prefixado representaria atividade meramente burocrática e desnecessária, que poderia receber qualquer outro qualificativo, menos o de jurisdicional. Portanto, repetimos: não há como negar executividade à sentença que contenha definição completa da norma jurídica individualizada, com as características acima assinaladas" (ob. cit, p. 52).

${ }^{364}$ Idem, em Processo de execução, cit., p. 308.

${ }^{365}$ RODRIGUES, Marcelo Abelha. Manual de execução civil. cit., p. 128.
} 
Neste sentido, a autor capixaba cita que o art. 74 do CPC dá eficácia ao provimento meramente declaratório que reconhece a responsabilidade do denunciado, em um típico caso de sentença declaratória com eficácia executiva nos termos ali descritos. Para referido processualista, a menção do inciso I do art. 475-N pelo legislador transmite, francamente, que aí se incluem as declaratórias da obrigação, especialmente as hipóteses do art. $4^{\circ}$, parágrafo único do Código, ou seja, quando reconhecedoras do ilícito. ${ }^{366}$

Paulo Henrique dos Santos Lucon, por sua vez, sustenta que se a sentença meramente declaratória contiver todos os elementos identificadores da obrigação sujeitos, prestação, liquidez e exigibilidade - não há como se negar sua eficácia executiva, atentando contra o bom senso e a economia processual a imposição de uma nova cognição para que sentença futura imponha apenas a sanção executiva. ${ }^{367}$

Luiz Rodrigues Wambier corrobora tal entendimento ao afirmar que se extrai da letra da nova norma jurídica que não só as sentenças condenatórias, mas também as sentenças declaratórias podem constituir título executivo, bastando, para tanto, que a sentença reconheça a existência de obrigação. ${ }^{368}$

Ronaldo Vasconcelos afirma que a nova redação que substituiu aquela do revogado art. 584, inc. I do CPC representa um grande avanço contra o formalismo exagerado no processo, de forma que a sentença civil não precisa ser condenatória para dar ensejo à execução, bastando o reconhecimento da existência da obrigação, declarando imperativamente o que é devido (an debeatur). Conclui, ainda, que se a sentença meramente declaratória contiver todos os elementos identificadores do título executivo sujeitos, certeza, liquidez e exigibilidade - não há como negar sua eficácia executiva. ${ }^{369} \mathrm{E}$ mesmo que a sentença não tenha definido o quantum devido, ainda assim ela não perde a executividade, desde que seja submetida à instauração de fase liquidativa.

\footnotetext{
${ }^{366}$ RODRIGUES, Marcelo Abelha. Manual de execução civil. cit., p. 128. O autor afirma que o legislador pretendeu com isso dar maior efetividade ao processo, evitando que o jurisdicionado que já tivesse uma declaração desse tipo tivesse ainda que propor uma ação condenatória.

${ }^{367}$ LUCON, Paulo Henrique do Santos. Coisa julgada, efeitos da sentença, coisa julgada inconstitucional e embargos à execução do art. 741, par. ún.. Revista do Advogado (São Paulo), São Paulo, v. 84, 2005, p. 152. ${ }^{368}$ WAMBIER, Luiz Rodrigues. Sentença Civil: Liquidação e Cumprimento. $3^{\text {a }}$ Ed. São Paulo: Revista dos Tribunais, 2006, p. 42.

${ }^{369}$ VASCONCELOS, Ronaldo, Eficácia executiva das sentenças declaratórias no CPC (Lei n. 11.232/05), cit., p. 106/109.
} 
Didier Jr, Cunha, Braga e Oliveira também aceitam a eficácia executiva da sentença declaratória, mesmo sob a égide do texto anterior, seja como consequência do direito fundamental à efetividade, seja em razão da absoluta desnecessidade e impossibilidade de instauração de nova atividade cognitiva judicial para apurar o que já está acobertado pela coisa julgada. Da mesma forma, também afastam a inconstitucionalidade do dispositivo, já que a redação proposta pelo Senado apenas aprimora o texto anterior, sem inovar substancialmente, ante a previsão do art. $4^{\circ}$ do CPC..$^{370}$

Neste sentido, não se nega a possibilidade de o demandante apenas querer a mera certificação, mesmo em situação em que seria possível o pleito condenatório. A questão que se coloca é se uma vez obtida essa certificação, poderá o vencedor, em outro momento, pedir a execução da prestação. Ou teria ele de entrar com nova ação de conhecimento, em que o magistrado ficaria vinculado ao efeito positivo da coisa julgada, e a sua cognição ficaria limitada, inevitavelmente, às matérias constantes do art. 475-L? Que ação seria essa segunda, em que se parte da coisa julgada, para efetivar o quanto ali decidido, e cuja cognição é limitada?

Essas perguntas são postas por Didier Jr, Cunha, Braga e Oliveira ${ }^{371}$, indicando que parece se tratar de uma ação executiva, pois se assim não fosse, teria de ser outra ação de conhecimento, destinada apenas a obter uma sentença que contenha a afirmação "condeno o réu". Isso, porque nada mais poderia ser revisto pelo juiz, eis que já produzida coisa julgada material sobre o direito a uma prestação, já certificado na primeira sentença.

Segundo os mencionados autores, não admitir a execução da sentença declaratória seria submeter a parte a um processo cujo resultado não pode ser diferente, exigindo-se

\footnotetext{
${ }^{370}$ DIDIER JR., Fredie; CUNHA, Leonardo Carneiro da; BRAGA, Paula Sarno; OLIVEIRA, Rafael. ob. cit., p. 156/157. Para fins de informação de doutrina, na nota 45 da página 160 da referida obra, há menção daqueles que se manifestaram favoráveis à atribuição de eficácia executiva da sentença declaratória, que citamos alguns: "SANTOS, Ernane Fidélis dos. As reformas de 2005 do Código de Processo Civil. São Paulo: Saraiva, 2006, p. 29-30; (...) CARMONA, Carlos Alberto. 'Cumprimento da sentença conforme a Lei n. 11.232/2005'. Processo civil - aspectos relevantes. Bento Herculano Duarte e Ronnie Preuss Duarte (coord.). São Paulo: Método, 2007, v. 2, p. 156; (...) LUCON, Paulo. 'Sentença e liquidação no CPC (Lei 11.232/2005)'. Processo e constituição - estudos em homenagem ao Professor José Carlos Barbosa Moreira. Luiz Fux, Nelson Nery Jr. e Teresa Arruda Alvim Wambier. São Paulo: RT, 2006, P. 915; (...) CALMON FILHO, Petrônio. 'Sentença e títulos executivos judiciais'. A nova execução de títulos judiciais comentários à Lei 11.232/05. Sérgio Renault e Pierpaolo Bottini (coord.). São Paulo: Saraiva, 2006, p. 100101".

${ }^{371}$ DIDIER JR., Fredie; CUNHA, Leonardo Carneiro da; BRAGA, Paula Sarno; OLIVEIRA, Rafael. ob. cit., p. 162.
} 
uma nova ação de conhecimento com a única finalidade de obter uma nova sentença que contenha o verbo condenar, em manifesta inefetividade processual, com a submissão da parte a um processo injusto, que contraria o princípio da duração razoável do processo. Reconhecido o direito a uma prestação, com a certeza e a exigibilidade da obrigação, e estando líquido o valor, já se deve permitir a execução. Não havendo, ainda, liquidez, será necessária, antes de se instaurar a execução, uma liquidação de sentença, nos termos do art. 475-A a $475-\mathrm{H}$ do CPC. ${ }^{372}$

Além dos mencionados doutrinadores, é possível verificar a mesma posição em diversos artigos publicados em revistas e sites especializados, o que denota a força que ganha a tese e sua relevância na aplicação da disposição nos casos concretos. ${ }^{373}$

O Código de Processo Civil comentado por Theotônio Negrão também chega na mesma conclusão. Após reconhecer que para se realizar o cumprimento da sentença ou qualquer execução é preciso verificar o inadimplemento do devedor, que se caracteriza caso este não satisfaça a obrigação certa, líquida e exigível, consubstanciada em título executivo (art. 580), afirma que o Código não mais se refere à sentença condenatória, mas à sentença que reconheça a existência de obrigação, o que confere eficácia executiva também à sentença declaratória. ${ }^{374}$

Reconhecida a eficácia executiva da sentença declaratória, outras questões merecem estudo. Pode ocorrer de uma única sentença previr várias espécies de prestações ou tutelas jurisdicionais: pagar, fazer, entregar. Para Sérgio Shimura, neste caso haverá

${ }^{372}$ DIDIER JR., Fredie; CUNHA, Leonardo Carneiro da; BRAGA, Paula Sarno; OLIVEIRA, Rafael. ob. cit., p. 162.

${ }^{373}$ Cite-se, por exemplo, MEDINA, José Miguel Garcia. A sentença declaratória como título executivo Considerações sobre o art. 475-N, I, do CPC. Revista de Processo. São Paulo: RT, 2006, n. 136, p. 76-77; PEREIRA, Rafael Caselli. O dogma da condenatoriedade..., cit.; PINHO, Frederico Andrade de Macedo. Sentença Meramente declaratória, título executivo e execução pelo réu. Jus Navigandi, Teresina, ano 14, n. 2273, 21 set. 2009. Disponível em: 〈http://jus.com.br/revista/texto/13531〉. Acesso em: 4 dez. 2011; entre outros.

374 Além disso, conclui que não há razão alguma, lógica ou jurídica, para submeter tal sentença, antes da execução, a um segundo juízo de certificação, até porque a nova sentença não poderia chegar a resultado diferente do da anterior, sob pena de comprometimento da garantia da coisa julgada, assegurada constitucionalmente. E instaurar um processo de cognição sem oferecer às partes e ao juiz outra alternativa de resultado que não um, já prefixado, representaria atividade meramente burocrática e desnecessária, que poderia receber qualquer outro qualificativo, menos o de jurisdicional (Resp 587.091, $1^{\mathrm{a}} \mathrm{T}$ T-STJ) (Código de Processo Civil e Legislação Processual em vigor, $40^{\mathrm{a}}$ edição, Saraiva, nota $1 \mathrm{f}$ ao art. 475-N, I). 
tantos procedimentos quantos forem as obrigações consubstanciadas na decisão judicial. A efetivação de cada obrigação comportará um procedimento específico. ${ }^{375}$

De outro lado, se no polo passivo constarem entes distintos, que reclamem procedimento específico, o cumprimento da sentença dar-se-á de acordo com o respectivo rito legal. O mesmo processualista exemplifica com o caso de constarem como devedores o particular e a Fazenda Pública. Contra o primeiro, segue-se o procedimento padrão previsto no art. 475-I e seguintes do CPC; contra a Fazenda Pública, exige-se o caminho previsto no art. 730 do CPC, cuja forma defensiva continua sendo a ação de embargos, prevista no art. 741 do CPC. $^{376}$

Questão que pode surgir no momento da execução da sentença é no caso de haver reconhecimento em favor de terceiro. Inicialmente, recorde-se o que já se falou acerca da coisa julgada e seus limites subjetivos acima. ${ }^{377}$ A esse respeito, Dinamarco afirma que há duas razões básicas pelas quais a autoridade da coisa julgada não deve ir e não vai além dos sujeitos processuais: a garantia do contraditório e o desinteresse dos terceiros pelos resultados do processo que não lhes afetam diretamente a esfera de direitos e obrigações. ${ }^{378}$ 379

Da regra aparentemente absoluta do art. 472 do Código, poderia emanar a impressão de que jamais alguém, sem ter sido parte no processo, viesse de algum modo a suportar qualquer vínculo inerente à auctoritas rei judicatae. Contudo, as múltiplas

\footnotetext{
${ }^{375}$ SHIMURA, Sérgio. A execução..., cit., p. 561/562.

${ }^{376}$ SHIMURA, Sérgio. A execução..., cit., p. 562.

${ }^{377} \mathrm{~V}$. item 1.2.4.

378 DINAMARCO, Cândido Rangel. Instituições..., vol. III, cit., p. 316. Os terceiros absolutamente indiferentes, que compõem um número infinito de pessoas, praticamente toda a população do globo terrestre, não são autorizados a repor em discussão os efeitos da sentença proferida inter alios, não porque a coisa julgada os atinja, mas porque sua vida não fica afetada por eles.

$379 \mathrm{O}$ processualista ainda afirma que o direito infraconstitucional fornece apenas algumas indicações esparsas, indiretas e setoriais, da intenção de não tolerar a eficácia da sentença além das partes, como (a) ao vedar o julgamento do mérito entre partes ilegítimas, sem a menos utilidade porque não pode atingir sujeitos legitimados que não hajam sido partes, (b) ao limitar o credor e devedor figurantes no título executivo judicial a legitimidade ativa e passiva para a execução forçada (arts. 566, inc. I, e 568, inc. I, c/c art. 475-R) porque o contrário conduziria a permitir benefícios ou constrições a quem não haja sido parte no processo de conhecimento, (c) ao municiar com a arma dos embargos de terceiro o sujeito cujos bens são atingidos por constrição judicial, sem que seja parte no processo em que esta tem lugar (art. 1046 ss.), (d) ao admitir como fundamento para impugnar a execução por título judicial o fato de o executado não haver sido regularmente citado no processo de conhecimento nem comparecido espontaneamente para defender-se (art. 475-L, I), porque, mesmo figurando como parte na demanda, o sujeito não citado não se torna parte no processo (ob. cit., p. 214/215).
} 
situações em que no cotidiano da vida as pessoas e suas próprias relações jurídicas se entrelaçam com outras pessoas e com outras relações, revelam que nem todos os terceiros são absolutamente indiferentes aos resultados do processo de que não foram partes.

Existem duas classes de terceiros que de algum modo estão ligados aos sujeitos do processo ou ao seu objeto e, por consequência, aos efeitos que a sentença de mérito produzirá e à coisa julgada da qual se revestirá: os titulares de situação jurídica não afetada sequer indiretamente pela sentença, mas que dela possam receber um prejuízo de fato, e os sujeitos de uma situação jurídica incompatível com a decisão. Tanto quanto os absolutamente indiferentes, os terceiros que recebem mero prejuízo de fato são destituídos de legitimidade ad causam para questionar a sentença ou, de algum modo, postular a neutralização de seus efeitos substanciais. ${ }^{380}$

Além disso, a apreciação pelo juiz dos direitos, obrigações e das meras pretensões são fundamento para decidir sobre o objeto do processo. Essa apreciação incidenter tantum está na motivação da sentença, não no decisório, não ficando pela regra do Código coberta pela coisa julgada material sequer em relação às partes, já que os motivos não fazem coisa julgada (art. 469, I, CPC).

Dessa forma, não podem os terceiros beneficiar-se de declaração contida na fundamentação ou dispositivo da sentença em processo do qual não são parte. Não se confunda tal assertiva, contudo, com os chamados efeitos diretos da sentença - aqueles consistentes em alguma declaração, constituição capaz de se projetar de modo favorável ou desfavorável sobre a esfera de direitos de uma pessoa - que, além das partes, atingem aqueles defendidos por algum substituto processual. ${ }^{381}$

\subsubsection{A jurisprudência}

\footnotetext{
${ }^{380}$ DINAMARCO, Cândido Rangel. Instituições..., vol. III, $6^{\mathrm{a}}$ ed., cit., p. 324. Para alguns efeitos reflexos da sentença, todavia, são legitimados certos sujeitos que não hajam sido partes no processo. Em algumas situações a lei permite que de alguma forma se relacionem com esta ou dela são dependentes. Pode ocorrer a intervenção do terceiro (assistente, opoente, nomeado a autoria, chamado ao processo, litisdenunciado), a partir de quando deixará de ser terceiro e será parte.

${ }^{381}$ DINAMARCO, Cândido Rangel. Instituições..., vol. III, 6a ed., cit., p. 326. É o caso da massa de sujeitos substituídos pelo Ministério Público ou alguma associação em processo coletivo por direitos individuais homogêneos, nos termos do art. 103, inc. III do Código de Defesa do Consumidor. Está na realidade afirmando que todos esses sujeitos são beneficiados pelos efeitos diretos da sentença que julga procedente a ação, de modo a terem à sua disposição o próprio título executivo consistente nessa sentença. A respeito, v. item 1.2.2.
} 
Não só a doutrina como também a jurisprudência vem se manifestando sobre o assunto. Através da rede mundial de computadores e utilizando-se de palavras-chave na pesquisa de jurisprudência, é possível encontrar julgados nos principais tribunais.

O Superior Tribunal de Justiça (STJ), que é a mais alta corte em matéria legal, já se manifestou expressamente em vários casos no sentido de admitir a eficácia executiva da sentença declaratória, como no AgRg nos EDcl no RESP 796.343-PE ${ }^{382}$, RESP 602.469$\mathrm{BA}^{383}$, RESP 1.114.404-MG ${ }^{384}$, RESP 745.350-SP, RESP 1.261.888/RS ${ }^{385}$, RESP 1.192.783/RS ${ }^{386}$, AgRg no RESP 1.187.755/RS, RESP 1.188.796/DF ${ }^{387}$.

${ }^{382}$ Confira-se trecho do voto do Desembargador Convocado do TJ/SP Celso Limongi: "A questão que chega a este Tribunal é a possibilidade de se executar sentença declaratória com conteúdo nitidamente condenatório, como é o caso dos autos, em que foi reconhecido aos servidores o direito à percepção e incorporação da gratificação de raio- $x$.

O entendimento que prevalece nesta Corte é o de que é desnecessário dar-se início a uma nova ação de conhecimento para se rediscutir um direito que já foi proclamado em ação anterior, vez que tal procedimento seria não só inútil, mas, principalmente, afrontoso aos princípios da economia e celeridade processual e à própria Jurisdição.” (AgRg nos EDcl no RESP 796.343-PE, DJ 14/04/2009).

${ }^{383}$ Confira-se trecho da ementa do julgado: "1. A doutrina processual moderna rompeu o dogma de que as sentenças declaratórias nunca seriam dotadas de eficácia executiva. Passou a entender que, quando a sentença, mesmo declaratória, trouxer a definição integral da norma jurídica individualizada, inexiste razão lógica para, antes da execução, ajuizar-se nova ação com o objetivo de mais uma vez certificar o provimento. Precedentes da Seção: EREsp 609.266/RS, Rel. Min. Teori Albino Zavascki, DJU de 11.09 .06 e EREsp 502.618/RS, Rel. Min. João Otávio de Noronha, DJU de 01.07.05." (RESP 602.469-BA, Relator Ministro Castro Meira, $2^{\text {a }}$ Turma, DJ 16/8/2007).

${ }^{384}$ Confira-se trecho da ementa do julgado: "1."A sentença declaratória que, para fins de compensação tributária, certifica o direito de crédito do contribuinte que recolheu indevidamente o tributo, contém juízo de certeza e de definição exaustiva a respeito de todos os elementos da relação jurídica questionada e, como tal, é título executivo para a ação visando à satisfação, em dinheiro, do valor devido" (REsp n. 614.577/SC, Ministro Teori Albino Zavascki)" (RESP 1.114.404/MG, Relator Ministro Mauro Campbell Marques, $1^{\text {a }}$ Seção, DJ 10/2/2010).

${ }^{385}$ Confira-se trecho da ementa do julgado: "1. Com a atual redação do art. 475-N, inc. I, do CPC, atribuiuse "eficácia executiva" às sentenças "que reconhecem a existência de obrigação de pagar quantia".

2. No caso concreto, a sentença que se pretende executar está incluída nessa espécie de provimento judicial, uma vez que julgou parcialmente procedente o pedido autoral para (i) reconhecer a legalidade do débito impugnado, embora (ii) declarando inexigível a cobrança de custo administrativo de $30 \%$ do cálculo de recuperação de consumo elaborado pela concessionária recorrente, e (iii) discriminar os ônus da sucumbência (v. fl. 26, e-STJ).

3. Recurso especial provido. Acórdão submetido ao regime do art. 543-C do CPC e da Resolução STJ $n$. 8/08.” (RESP 1.261.888/RS, Relator Ministro Mauro Campbell Marques, $1^{\text {a }}$ Seção, DJ 9/11/2011).

${ }^{386}$ Confira-se trecho da ementa do julgado: "1. Em verdade, na hipótese dos autos, vislumbra-se a alegada violação dos arts. 475-I e 475-N do CPC, porquanto, à luz desse dispositivo, a sentença proferida no processo civil que reconhece a existência de dada obrigação de pagar é título executivo hábil a fundar pedido de cumprimento pelo réu de pagamento pelo autor da dívida reconhecida, sobretudo diante do princípio da celeridade e efetividade da prestação jurisdicional, consagrado expressamente no art. $5^{\circ}$, inc. LXXVIII, da CR/88 e objetivado pela Lei $n$. 11.232/2005. Não é outro o entendimento que se colhe nessa Corte. Precedentes." (RESP 1.192783/RS, Relator Ministro Mauro Campbell Marques, $2^{\mathrm{a}}$ Turma, DJ 4/8/2011).

387 Confira-se trecho da ementa do julgado: “3. Consoante reiterada jurisprudência deste STJ, pode o contribuinte manifestar a opção de receber o indébito tributário, certificado por sentença declaratória 
No caso do RESP 745.350/SP, por exemplo, tratou-se de ação declaratória de inexistência de obrigação de recolhimento de ICMS que, contudo, não foi instruída com os documentos indispensáveis para análise do creditamento do tributo, bem como o valor da causa. Neste sentido, assumindo que a sentença que reconhecesse tal direito, ainda que declaratória, seria título executivo judicial,o STJ afirmou que deveria a parte autora ter instruído sua petição inicial com referida documentação, nos termos dos arts. 282 e 283 do CPC. $^{388}$

Por outro lado, no caso do RESP 602.469/BA, o STJ, apesar de reconhecer a eficácia executiva da sentença declaratória, não autorizou a compensação do indébito tributário resultante da declaração de inexigibilidade de determinado tributo, em razão da inexistência de pedido específico na demanda. Ou seja, apesar do reconhecimento da possibilidade de execução da sentença declaratória, o próprio julgado afirmou que a mera declaração na sentença não era suficiente para possibilitar a execução do julgado, ante ausência de pedido específico. Na verdade, nesse caso, não houve na sentença o reconhecimento da existência de obrigação de pagar quantia, mas sim da inexistência da obrigação de pagar quantia, o que impossibilita a execução com fundamento no art. 475-N, inc. $\mathrm{I}^{389}$

transitada em julgado, por meio de precatório ou por compensação, já que ambos constituem formas de execução da decisão judicial.” (RESP 1188796/DF, Rel. Ministra Eliana Calmon, 2a Turma, DJ 15/06/2010). ${ }^{388}$ Confira-se trecho da ementa do julgado: "1. Na atual sistemática Processual Civil Brasileira, que preza pela celeridade e a utilidade da jurisdição, não há como em uma ação que visa a declaração do direito ao creditamento de ICMS apenas declarar tal direito sem haver uma condenação, no caso, repetição ou compensação do débito.

2. Nessa concepção, na hipótese dos autos o pedido realizado de cunho declaratório tem, de fato, caráter condenatório, uma vez que a sentença conterá juízo de certeza e de definição a respeito de todos os elementos da relação jurídica questionada, reconhecendo ou não em favor do contribuinte o direito de haver a repetição ou compensação de valor indevidamente recolhido." (RESP 745350/SP, Relator Ministro Mauro Campbell Marques, $2^{\mathrm{a}}$ Turma, DJ 24/11/2009).

389 Confira-se trecho do voto do Ministro Relator Castro Meira: "Em atenção ao pedido da ação de conhecimento, a sentença alcançada pela recorrente declarou unicamente "... a inexistência da obrigação de recolher a contribuição prevista no art. $3^{\circ}$, inciso I, da Lei 7.787/89, incidente sobre a remuneração paga a administradores e trabalhadores autônomos" (fl. 81 do apenso).

Nada decidiu, por exemplo, sobre o regime de compensação a que estaria sujeito o contribuinte, sobre a prescrição tributária ou, ainda, ante o art. 166 do CTN, sobre a sua legitimidade para reaver os supostos pagamentos indevidos, matérias essenciais ao reconhecimento do direito de compensar o indébito tributário, mesmo que administrativamente.

Desse modo, não assiste razão à recorrente quando, diante de providencia jurisdicional puramente declaratória da inexistência da obrigação de recolher a exação hostilizada, instaurou processo de liquidação com o objetivo de mensurar o montante que possuiria, "... a ser compensado, ainda que na esfera administrativa"'”. 
Conforme noticiado supra, o Ministro Teori Albino Zavascki foi pioneiro em defender a eficácia executiva da sentença declaratória em seus julgados do Superior Tribunal de Justiça, antes mesmo da modificação da lei 11.232/05 no Código. Citem-se o RESP 588.202/PR - no qual o ministro faz referência a voto seu anteriormente prolatado no RESP 544.189/MG, o qual ainda citava outros precedentes daquela corte -, e RESP 614.577/SC. Além de Teori, o Ministro João Otávio de Noronha, também anteriormente à lei 11.232/05 entendeu pela eficácia executiva da sentença declaratória, como no EREsp $502.618 / \mathrm{RS}$.

No caso do RESP 588.202/PR, a causa referiu-se, em suma, a uma questão tributária, em que a parte discutiu em uma demanda declaratória o direito de compensar um tributo com outro. Sobreveio uma lei, em meio à discussão processual, possibilitando a restituição por meio de precatório. O contribuinte então, de posse da declaração que dava direito à compensação - e reconhecia, portanto, que o tributo pago não era devido ao Estado -, pleiteou a execução dessa sentença contra a Fazenda Pública, para que ela fosse obrigada a restituir o que foi pago a maior, pela via do precatório. O STJ, diante do pedido, acolheu a tese de que a sentença declaratória poderia configurar título executivo, possibilitando que a sentença que reconhecia a existência de crédito fosse executada.

De outra parte, há julgados do Ministro Teori posteriores à modificação da lei, também no mesmo sentido, como o ERESP $609.266 / \mathrm{RS}^{390}$ Neste recurso especial, foi

390 DJ 23/08/2006, cuja ementa se transcreve: PROCESSUAL CIVIL. TRIBUTÁRIO. VALORES INDEVIDAMENTE PAGOS A TÍTULO DE FINSOCIAL. SENTENÇA DECLARATÓRIA DO DIREITO DE CRÉDITO CONTRA A FAZENDA PARA FINS DE COMPENSAÇÃO. EFICÁCIA EXECUTIVA DA SENTENÇA DECLARATÓRIA, PARA HAVER A REPETIÇÃO DO INDÉBITO POR MEIO DE PRECATÓRIO.

1. No atual estágio do sistema do processo civil brasileiro não há como insistir no dogma de que as sentenças declaratórias jamais têm eficácia executiva. O art. 4\%, parágrafo único, do CPC considera "admissível a ação declaratória ainda que tenha ocorrido a violação do direito", modificando, assim, o padrão clássico da tutela puramente declaratória, que a tinha como tipicamente preventiva. Atualmente, portanto, o Código dá ensejo a que a sentença declaratória possa fazer juízo completo a respeito da existência e do modo de ser da relação jurídica concreta.

2. Tem eficácia executiva a sentença declaratória que traz definição integral da norma jurídica individualizada. Não há razão alguma, lógica ou jurídica, para submetê-la, antes da execução, a um segundo juízo de certificação, até porque a nova sentença não poderia chegar a resultado diferente do da anterior, sob pena de comprometimento da garantia da coisa julgada, assegurada constitucionalmente. E instaurar um processo de cognição sem oferecer às partes e ao juiz outra alternativa de resultado que não um, já prefixado, representaria atividade meramente burocrática e desnecessária, que poderia receber qualquer outro qualificativo, menos o de jurisdicional.

3. A sentença declaratória que, para fins de compensação tributária, certifica o direito de crédito do contribuinte que recolheu indevidamente o tributo, contém juízo de certeza e de definição exaustiva a respeito de todos os elementos da relação jurídica questionada e, como tal, é título executivo para a ação 
objeto de discussão a possibilidade de execução da sentença que reconhecia o crédito de FINSOCIAL da empresa autora contra a União, viabilizando-se a compensação desse crédito com outros tributos efetivamente devidos pela empresa. O resultado do julgamento foi no sentido de permitir a execução da sentença.

A corroborar a afirmação, há julgados monocráticos do STJ aplicando a eficácia executiva da sentença declaratória, com base no art. 557, § $1^{\circ}$-A do CPC, o qual só é aplicável nos casos de jurisprudência dominante do STF ou de tribunal superior. São exemplos as decisões do Ministro Herman Benjamin no RESP 1.191.099 e do Ministro Hamilton Carvalhido nos RESPs 1.187.755/RS e 1.190.860/RS.

Os tribunais locais também já puderam analisar a questão. O Tribunal de Justiça de São Paulo (TJSP) reconheceu a eficácia executiva da sentença declaratória nos julgamentos dos Agravo de Instrumento 0273197-92.2009.8.26.0000391, Agravo de Instrumento 0131562-55.2011.8.26.0000 ${ }^{392}$, Apelação no 0017697-21.2000.8.26.0071 ${ }^{393}$, Agravo de Instrumento $\mathrm{n}^{\text {o }}$ 0164656-91.2011.8.26.0000 ${ }^{394}$, Agravo de Instrumento 0177628-93.2011.8.26.0000 ${ }^{395}$, Agravo de Instrumento 0000276-51.2011.8.26.0000 Agravo de Instrumento $\mathrm{n}^{\mathrm{o}}$ 0093380-97.2011.8.26.0000 397 , entre outros.

O Tribunal de Justiça do Rio de Janeiro (TJRJ), da mesma maneira, no julgamento do Agravo de Instrumento n. ${ }^{\circ}$ 0036398-92.2010.8.19.0000 ${ }^{398}$ e da Apelação Cível $n^{\circ}$ 0094552-37.2009.8.19.0001 ${ }^{399}$, também considerou a tese na solução do conflito.

visando à satisfação, em dinheiro, do valor devido. Precedente da $1^{a}$ Seção: ERESP 502.618/RS, Min. João Otávio de Noronha, DJ de 01.07.2005. ”(grifos nossos).

${ }^{391}$ Relator Desembargador Piva Rodrigues, que é professor de processo civil da USP, $9^{a}$ Câmara de Direito Privado, Julgamento em 23/2/2010.

392 Relator Desembargador Edgar Rosa, 30ª Câmara de Direito Privado, Julgamento em 9/11/2011, disponível em https://esaj.tjsp.jus.br/cjsg/getArquivo.do?cdAcordao=5526406\&vlCaptcha=pzvka

${ }^{393}$ Relator Desembargador Thiago de Siqueira, $14^{a}$ Câmara de Direito Privado, Julgamento em 14/09/2011, disponível em https://esaj.tjsp.jus.br/cjsg/getArquivo.do?cdAcordao=5409088

${ }^{394}$ Relator Desembargador Moura Ribeiro, $11^{a}$ Câmara de Direito Privado, Julgamento em 15/9/2011, disponível em https://esaj.tjsp.jus.br/cjsg/getArquivo.do?cdAcordao=5401534\&vlCaptcha=atbez

${ }^{395}$ Relator Desembargador Renato Rangel Desinato, $11^{\text {a }}$ Câmara de Direito Privado, Julgamento em $18 / 8 / 2011$.

${ }^{396}$ Relator Desembargador Ademir Benedito, $21^{\text {a }}$ Câmara de Direito Privado, Julgamento em 31/8/2011, disponível em https://esaj.tjsp.jus.br/cjsg/getArquivo.do?cdAcordao=5395299.

${ }^{397}$ Relator Desembargador Julio Vidal, $28^{\text {a }}$ Câmara de Direito Privado, Julgamento em 9/8/2011, disponível em https://esaj.tjsp.jus.br/cjsg/getArquivo.do?cdAcordao=5330160.

${ }^{398}$ Relator Desembargador Luiz Fernando Ribeiro de Carvalho, $3^{\text {a }}$ Câmara Cível, Julgamento em 16/2/2011, disponível em

http://srv85.tjrj.jus.br/ConsultaDocGedWeb/faces/ResourceLoader.jsp?idDocumento=000326232EACCA6E 8A1FF308AFE66C104326AFC4025D5632. 
O Tribunal de Justiça de Minas Gerais (TJMG), por sua vez, adotou a tese no julgamento do Agravo de Instrumento 1.0481.00.007112-8/001 $1^{400}$, Apelação $n^{\circ}$
$1.0024 .03 .945984-7 / 002^{401}$ e Agravo de Instrumento $n^{\circ} 1.0145 .05 .224625-6 / 002^{402}$.

O Tribunal de Justiça do Espírito Santo (TJES) reconheceu a eficácia executiva da sentença declaratória no Agravo de Instrumento $\mathrm{n}^{\mathrm{o}} 024.100 .921 .584^{403}$ e Agravo de Instrumento $\mathrm{n}^{\mathrm{o}}$ 047.079.000.817 $7^{404}$. O Tribunal de Justiça do Paraná (TJPR) corroborou o

${ }^{399}$ Relator Desembargador Luiz Felipe Francisco, $8^{\text {a }}$ Câmara Cível, Julgamento em 15/3/2011, disponível em http://srv85.tjrj.jus.br/ConsultaDocGedWeb/faces/ResourceLoader.jsp?idDocumento=000331CAC15452A05 377E2FD1346A1061C968DC402601D3F

${ }^{400}$ Relator Desembargador Electra Benevides, 10ª Câmara Cível, Julgamento em 16/6/2009, disponível em http://www.tjmg.jus.br/juridico/sf/proc_resultado2.jsp?listaProcessos=00711286120008130481

${ }^{401}$ Relator Desembargador Francisco Kupidlowski, 13a Câmara Cível, Julgamento em 4/8/2011, disponível em http://www.tjmg.jus.br/juridico/sf/proc_resultado2.jsp?listaProcessos $=94598479220038130024$

${ }^{402}$ Relator Desembargador Evangelina Castilho Duarte, 14 Câmara Cível, Julgamento em 17/6/2010, disponível

http://www.tjmg.jus.br/juridico/sf/proc_resultado2.jsp?listaProcessos=22462562620058130145

${ }_{403}$ Relator Desembargador Namyr Carlos de Souza Filho, $2^{\text {a }}$ Câmara Cível, Julgamento em 17/5/2011, disponível

http://www.tj.es.gov.br/consulta/cfmx/portal/Novo/pdf_gen.cfm?cd_sessao=10338\&cd_recurs=305864

${ }^{404}$ Relator Desembargador Álvaro Manoel Rosindo Bourguignon, 2 ${ }^{\mathrm{a}}$ Câmara Cível, Julgamento em 26/8/2008, disponível

em http://www.tj.es.gov.br/consulta/cfmx/portal/Novo/Ementa_sem_formatacao_ACORD.cfm?CDRECURS=22 3494. Confira-se trecho da ementa: "4. Após o advento da Lei 11.232/05, houve brusca alteração no sistema de execução de títulos judiciais no Brasil, em desenvolvimento à política reformista que buscou eliminar a dualidade processo de conhecimento/processo de execução, que fazia com que a parte, vencedora na demanda cognitiva e beneficiária da sentença condenatória, tivesse que instaurar novo processo (executivo), com todos os conhecidos percalços (custas, citação,. embargos, etc), para ver efetivado, na pratica, seu direito reconhecido na sentença.

(...)

6. A Lei 11.232/2005, ampliou o conceito de título executivo judicial (...) O novel dispositivo, com se vê, eliminou a exigência de condenatoriedade como elemento para caracterização de sua executividade, satisfazendo-se com que ela (a sentença) reconheça a existência de obrigação de fazer, não fazer, entregar coisa ou pagar quantia.

7. É inegável que, com o advento do mencionado art. 475-N do CPC, e instaurado novo regime jurídico dos títulos executivos, a sentença declaratória passou a qualificar-se como título executivo judicial, propiciando a instauração de processo de execução pelo parte que, por sentença, fora reconhecida titular de direito cuja satisfação incumba ao réu.

8 - Diante dessa nova sistemática, é perfeitamente viável que, reconhecido por sentença o direito de retenção pelo valor das benfeitorias erigidas, ainda que formulado apenas em, contestação, possa o réu deflagrar o respectivo procedimento executivo para ver-se satisfeito da importância reconhecida na sentença ou apurada em incidente de liquidação, pois a tanto se presta o segmento de certificação de seu direito declarado no édito sentencial que, pelas novas regras, possui eficácia executiva.

9. A alteração promovida pelo art. $475 \mathrm{~N}, \mathrm{I}$, do CPC enquadra-se no amplo movimento do asseguramento do acesso à justiça, que há muito, passou a integrar a categoria dos direitos fundamentais, inserido entre os direitos ditos de segunda geração - direitos sociais, econômicos, políticos e culturais. Esta garantia constitucional não objetiva apenas possibilitar que os litígios sejam levados ao conhecimento do Poder Judiciário através das petições. Significa também, e principalmente, que será dada uma solução ao caso concreto (respeitados os direitos e garantias constitucionais), sem exigências repetitivas, insanas e formalistas que tanto atuam em desprestígio da prestação jurisdicional." 
entendimento no julgamento do Agravo de Instrumento $\mathrm{n}^{\circ}$ 0.657.787- $7^{405}$ e Agravo de Instrumento $\mathrm{n}^{\mathrm{o}} 0.479 .886-1^{406}$.

Por fim, citem-se os Agravos de Instrumento $n^{\circ}$ s $70046374237^{407}, 70044462828^{408}$, $70042934729^{409}, 70041768631^{410}$, entre outros julgados do Tribunal de Justiça do Rio Grande do Sul (TJRS), que também adotaram a eficácia executiva da sentença declaratória. Vários são os julgados deste tribunal neste sentido, número comparativamente maior que o encontrado nos demais tribunais locais, sendo que em alguns casos o recurso foi julgado monocraticamente pelo relator, nos termos do art. 557 do CPC.

Além das Justiças dos Estados, o Tribunal Regional Federal da $3^{a}$ Região - SP e MS - $\left(\mathbf{T R F} / 3^{a}\right)$ já reconheceu a eficácia executiva da sentença declaratória no Agravo de Instrumento $\mathrm{n}^{\mathrm{o}}$ 2001.03.00.021510-9 $9^{411}$, Apelação Cível no 2006.61.09.001600-5 $5^{412} \mathrm{e}$

405 Relator Juiz Convocado Francisco Jorge, $17^{a}$ Câmara Cível, Julgamento em 7/7/2010, disponível em http://www.tj.pr.gov.br/portal/judwin/consultas/jurisprudencia/VisualizaPdf.asp?Processo=1234944\&Linha= $13 \&$ tipo $=1$

${ }^{406}$ Relator Desembargador Pericles Bellusci de Batista Pereira, 2a Câmara Cível, Julgamento em 12/8/2008, disponível em http://www.tj.pr.gov.br/asp/judwin/consultas/judwin/DadosProcesso.asp?Codigo=956670

407 Relator Desembargador Arminio José Abreu Lima da Rosa, $21^{\text {a }}$ Câmara Cível, Julgamento em 28/11/2011, disponível

em https://www1.tjrs.jus.br/site_php/consulta/consulta_processo.php?nome_comarca=Tribunal+de+Justi\%E7a\& versao $=\&$ versao_fonetica $=1 \&$ tipo=1\&id_comarca=700\&num_processo_mask=70046374237\&num_process $\mathrm{o}=70046374237 \&$ codEmenta $=4486156 \&$ temIntTeor $=$ true

408 Relator Desembargador Jorge Maraschin dos Santos, 1ª Câmara Cível, Julgamento em 23/11/2011, disponível em http://www1.tjrs.jus.br/site_php/consulta/consulta_processo.php?nome_comarca=Tribunal+de+Justi\%E7a\&v ersao $=\& v e r s a o \_f o n e t i c a=1 \&$ tipo $=1 \& i d \_c o m a r c a=700 \&$ num_processo_mask=70044462828\&num_processo $=70044462828 \&$ codEmenta $=4477990 \&$ temIntTeor $=$ true

409 Relatora Desembargadora Walda Maria Melo Pierro, 20ª Câmara Cível, Julgamento em 22/09/2011, disponível

http://www1.tjrs.jus.br/site_php/consulta/consulta_processo.php?nome_comarca=Tribunal+de+Justi\%E7a\&v ersao $=\&$ versao_fonetica $=1 \&$ tipo $=1 \& i d \_c o m a r c a=700 \&$ num_processo_mask=70042934729\&num_processo $=70042934729 \&$ codEmenta $=4361034 \&$ temIntTeor $=$ true

Referido julgado cita ainda a Apelação Cível 7004060469 e os Agravos de Instrumento 70042236919, 70039780390 e 70036793743.

${ }^{410}$ Relatora Desembargadora Liége Puricelli Pires, $17^{\text {a }}$ Câmara Cível, Julgamento em 30/06/2011, disponível em

http://www1.tjrs.jus.br/site_php/consulta/consulta_processo.php?nome_comarca=Tribunal+de+Justi\%E7a\&v ersao $=\& v e r s a o \_f o n e t i c a=1 \&$ tipo $=1 \& i d \_c o m a r c a=700 \&$ num_processo_mask=70041768631\&num_processo $=70041768631 \&$ codEmenta $=4240597 \&$ temIntTeor $=$ true

${ }^{411}$ Relatora Juíza Federal Convocada Eliana Marcelo, $2^{\text {a }}$ Turma, Julgamento em 23/11/2010, disponível em http://www.trf3.jus.br/NXT/gateway.dll/bibjur/jur/jur10/dezembro/trf300310706.xml?f=templates $\$$ fn=docu ment-

frameset.htm $\$ \mathrm{q}=\% 5 \mathrm{~B}$ and $\% 3$ Asenten $\% 3 \mathrm{Fa} \% 20$ declaratoria $\% 20 \mathrm{t} \% 3 \mathrm{Ftulo} \% 20$ executivo $\% 5 \mathrm{D} \% 20 \$ \mathrm{x}=$ server $\$ 3$ .0\#LPHit0

Confira-se trecho da ementa: "1. Ao tempo em que opostos os embargos à execução, o acórdão meramente declaratório não possuía força executiva, nos termos do artigo 584, inciso I, do Código de Processo Civil. 
Apelação Cível 1999.61.00.031563-9 $9^{413}$. No mesmo sentido, o Tribunal Regional Federal da $1^{\text {a }}$ Região - DF, GO, MG, MT, BA, TO, PI, MA, PA, AP, RO, AM, RR e AC $\left(\mathbf{T R F} / 1^{\mathbf{a}}\right)$ considerou a sentença declaratória possuidora de eficácia executiva no Agravo de Instrumento $\mathrm{n}^{\mathrm{o}}$ 0039568-77.2008.4.01.0000/AM ${ }^{414}$ e na Apelação em Mandado de Segurança $\mathrm{n}^{\mathrm{o}}$ 2006.38.00.037477-7/MG ${ }^{415}$. Por fim, cite-se a Apelação Cível $\mathrm{n}^{\mathrm{o}}$ 2009.50.01.006075-2 $2^{416}$ como precedente do Tribunal Regional Federal da $2^{\mathrm{a}}$ Região - RJ e ES - (TRF/2a $)$

Mister destacar, por outro lado, que os tribunais também têm julgamentos no sentido de negar eficácia executiva à sentença declaratória. No Tribunal de Justiça de São Paulo (TJSP), por exemplo, isso ficou consignado no julgamento do Agravo de Instrumento $\mathrm{n}^{\mathrm{o}}$ 0177437-48.2011.8.26.0000 $0^{417}$, bem como no Agravo de Instrumento $\mathrm{n}^{\mathrm{o}}$ 0122093-82.2011.8.26.0000 ${ }^{418}$, no voto vencido da Desembargadora Lígia Araújo Bisogni, no sentido de que as demandas declaratórias não encerram a constituição de título

2. Com o advento da Lei $n^{\circ}$ 11.232/2005, o artigo 475-N, inciso I, do Código de Processo Civil passou a dispor que configura título executivo a sentença que reconheça a existência de obrigação de fazer, não fazer, entregar coisa ou pagar quantia.

3. A lei processual nova aplica-se de imediato aos feitos pendentes (Código de Processo Civil, artigo 1.211)."

${ }^{412}$ Relator Desembargador Federal Nelton dos Santos, $2^{\text {a }}$ Turma, Julgamento em 21/7/2009, disponível em

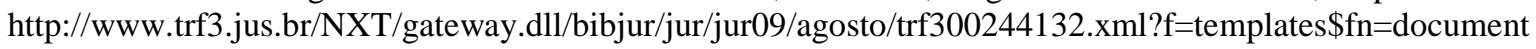
$-$

frameset.htm $\$ \mathrm{q}=\% 5 \mathrm{Band} \% 3$ Asenten $\% 3 \mathrm{Fa} \% 20$ declaratoria $\% 20 \mathrm{t} \% 3 \mathrm{Ftulo} \% 20$ executivo $\% 5 \mathrm{D} \% 20 \$ \mathrm{x}=$ server $\$ 3$ .0\#LPHit0

${ }^{413}$ Relator Desembargador Federal Nelton dos Santos, $2^{a}$ Turma, Julgamento em 3/10/2008, disponível em

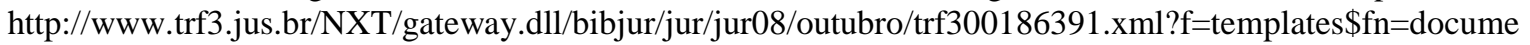
nt-frameset.htm \$q=1999.61.00.031563-9\%20\$x=server\$3.0\#LPHit0

${ }^{414}$ Relator Desembargador Federal Souza Prudente, $8^{\mathbf{a}}$ Turma, Julgamento em 9/11/2010, disponível em http://arquivo.trf1.jus.br/default.php?p1=395687720084010000

Confira-se trecho da ementa: "PROCESSUAL CIVIL E TRIBUTÁRIO. SENTENÇA DECLARATÓRIA DE INEXISTENCIA DE RELAÇÃO JURÍDICO TRIBUTÁRIA. EFICÁCIA EXECUTIVA. LIQUIDAÇÃO POR ARTIGOS. LIMITAÇÃO TEMPORAL DA SENTENÇA. PRESCRIÇÃO. NÃO OCORRÊNCIA.

I - Segundo entendimento jurisprudencial consolidado pelo colendo STJ, tem eficácia executiva a sentença declaratória que contém juízo de certeza e de definição exaustiva a respeito de todos os elementos da relação jurídica questionada. (...) (EREsp 609.266/RS, Rel. Ministro TEORI ALBINO ZAVASCKI, PRIMEIRA SEÇÃO, julgado em 23/08/2006, DJ 11/09/2006, p. 223).

II - Em sendo assim, não merece reparos a decisão recorrida que reconheceu a força executiva da sentença declaratória e deferiu a liquidação do julgado para se apurar os valores indevidamente recolhidos."

415 Relator Desembargador Federal Carlos Fernando Mathias, 8 a Turma, Julgamento em 9/11/2007, disponível em http://arquivo.trf1.jus.br/default.php?p1=200638000374777

${ }^{416}$ Relator Juiz Federal Convocado Theophilo Miguel, $3^{\text {a }}$ Turma Especializada, Julgamento em 20/7/2011, disponível em http://www2.trf2.gov.br/NXT/gateway.dll/2011/07-julho/05/2009.50.01.006075$2 \% 20 \% 20 \% 20 \% 20259480 . x m l$ f=templates $\$ \mathrm{fn}=$ document-frameset.htm $\$ \mathrm{q}=475$ -

$\mathrm{N} \% 20 \$ \mathrm{x}=$ server\$3.0\#LPHit1

417 Relator Desembargador Antonio Rigolin, 31 a Câmara de Direito Privado, Julgamento em 23/08/2011, disponível em https://esaj.tjsp.jus.br/cjsg/getArquivo.do?cdAcordao=5344640

418 Relator Desembargador Melo Colombi, 14 Câmara de Direito Privado, Julgamento em 24/08/2011, disponível em https://esaj.tjsp.jus.br/cjsg/getArquivo.do?cdAcordao=5406670 
executivo passível de execução. Ainda que reconhecendo que parte considerável da doutrina processualista moderna e a jurisprudência do C. Superior Tribunal de Justiça entendem pela possibilidade, a magistrada sustenta que caberia à agravante, se desejar, efetuar a cobrança do débito que entende devido pelas vias judiciais próprias.

\subsection{Reconhecimento de obrigação em favor do réu}

Como discorrido supra, a tutela jurisdicional não é a chamada tutela do autor, mas a de quem tem razão. ${ }^{419} \mathrm{O}$ reconhecimento do direito pode, portanto, ser dado em favor do autor ou em favor do réu. A sentença pode ter reconhecimento em favor do autor de obrigação de fazer, não fazer, entregar coisa ou pagar quantia, e nesse caso será título executivo judicial (art. 475-N, I), cuja execução se faz nos termos do art. 475-I, caput do CPC.

Por outro lado, o juiz, ao analisar a demanda e resolver a causa, pode verificar que é improcedente o pedido do autor e, além disso, reconhecer que, na realidade, quem tem direito a uma prestação é o réu. Neste sentido, a sentença pode reconhecer expressamente que o réu tem crédito ou outro direito em face do autor. A discussão que se coloca na prática processual contenciosa é se essa sentença pode ser executada pelo réu, já que, em tese, pode ser entendida como a sentença do art. 475-N, inc. I, que confere título executivo judicial em seu favor.

O processualista Humberto Theodor Junior entende que não parece possível pretender que toda sentença de improcedência do pedido, sendo declaratória negativa em relação à pretensão do autor, possa funcionar como título executivo em favor do réu, sempre que este invoque na contestação defesa indireta para contrapor relação obrigacional extintiva daquela em que se funda a ação. O que é objeto de correção judicial pela via da ação é o direito pretendido pelo autor, e não o possível direito do demandado. Este apenas resiste à pretensão tornada objeto do processo. ${ }^{420}$

A respeito, Carlos Alberto Carmona, ao comentar o artigo 475-N do CPC, suscita tal hipótese, bastando para tanto que a sentença, ao repelir o pedido declaratório negativo,

\footnotetext{
${ }^{419} \mathrm{~V}$. item 1.1 .

${ }^{420}$ THEODORO JR, Humberto. Curso..., cit., p. 22, nota 36.
} 
por exemplo, afirme a existência da relação jurídica que o autor queria negar, reconhecendo uma obrigação de pagar ou entregar coisa. ${ }^{421}$

Marcelo Abelha, por sua vez, afirma que apenas às sentenças declaratórias de procedência que reconheçam uma obrigação (art. $4^{\circ}$, parágrafo único do Código) é que é atribuída a eficácia executiva. Para referido autor, se tal fosse possível, então estaria solidificado o entendimento de que o réu, mesmo na condição de réu, exerce pretensão à declaração, que, dependendo do caso, ensejará a formação de título executivo. Seria, pois, como admitir uma natureza dúplice à contestação. ${ }^{422} 423$

Teori Albino Zavascki menciona o caso da sentença concedida em ações de desapropriação, na qual não há condenação contra o expropriante, que é o autor da ação, e nem contra o expropriado. Com efeito, a fixação, pela sentença, do valor indenizatório não significa reconhecimento do direito subjetivo do expropriado de recebê-lo e nem, portanto, da existência de uma prestação exigível, até porque ao poder expropriante assiste a faculdade de desistir do ato expropriatório, mesmo depois do trânsito em julgado, enquanto não efetivada a desapropriação. Ainda assim, é de se admitir a execução pelo expropriado para haver o valor da indenização ou de diferenças não pagas, após a efetiva desapropriação, com fundamento no art. 572 do CPC. ${ }^{424}$

\footnotetext{
${ }^{421}$ CARMONA, Carlos Alberto. In Código de Processo Civil Interpretado, Antônio Carlos Marcato (coord.), $3^{\mathrm{a}}$ ed, Ed. Atlas, 2008, p. 1615. Afirma o processualista: "Percebe-se, portanto, que o pleito declaratório que descrevi, em certa medida, toma ares de 'duplicidade', podendo o Autor não só sair vencido como ainda ver formado a favor do réu um título executivo judicial. E vale notar que tudo isso pode ocorrer independentemente de pedido do réu!'”.

${ }^{422}$ RODRIGUES, Marcelo Abelha. Manual de execução civil. cit., p. 128/129. O autor lembra que toda ação é bilateral, o que não se confunde com o dito. Assume que só o tempo irá mostrar a posição da jurisprudência em relação ao dispositivo.

${ }^{423}$ De acordo com Frederico Andrade de Macedo Pinho, não é em qualquer demanda que o réu sai vitorioso, onde a pretensão do autor tinha conteúdo declaratório, que autorizará a execução da norma individualizada. É necessário que o autor pretenda a declaração da inexistência de uma determinada prestação, sendo que a recíproca não é verdadeira, ou seja, caso o autor pretenda a declaração da existência de uma prestação, nesta última hipótese, a via executiva não será a aberta ao réu, eis que faltará na norma concreta o elemento do dever de prestar (PINHO, Frederico Andrade de Macedo. Sentença Meramente declaratória, título executivo e execução pelo réu. Jus Navigandi, Teresina, ano 14, n. 2273, 21 set. 2009. Disponível em: <http://jus.com.br/revista/texto/13531>. Acesso em: 4 dez. 2011).

424 ZAVASCKI, Teori Albino. Processo de execução, cit., p. 315/316. Art. 572. Quando o juiz decidir relação jurídica sujeita a condição ou termo, o credor não poderá executar a sentença sem provar que se realizou a condição ou que ocorreu o termo. Nesse caso, há realização da condição suspensiva para o nascimento do direito à indenização: o título executivo é composto pela sentença que fixou o valor do bem e pela prova demonstrativa da irreversibilidade da desapropriação.
} 
Pela possibilidade de formação de título executivo em favor do réu já deliberou monocraticamente o Superior Tribunal de Justiça, no RESP 1.195.122/RS, ao reconhecer a possibilidade de concessionária de energia executar sentença que julgou improcedente a demanda de usuário, na parte da demanda que reconheceu a existência do débito. ${ }^{425}$

O Tribunal de Justiça de São Paulo, da mesma forma, reconheceu no Agravo de Instrumento $\mathrm{n}^{\mathrm{o}}$ 0131562-55.2011.8.26.0000 a possibilidade da sentença que julga improcedente pedido do autor e reconhece obrigação em favor do réu fazer título executivo. Tal decisão citou precedentes do STJ (RESP 609.266/RS) e do próprio TJSP (AI n. ${ }^{\circ}$ 0273197-92.2009.8.26.0000) para reconhecer a eficácia executiva da sentença declaratória, para, em seguida, possibilitar a execução de valor de fatura emitida por concessionária de energia elétrica, cuja exigibilidade fora reconhecida na sentença. ${ }^{426}$

No mesmo sentido, podem ser citados os Agravos de Instrumento 70044462828, 70030473326, 70038746038, 70044758118, 70042685420, entre outros do TJRS, nos quais a empresa RIO GRANDE ENERGIA S/A - concessionária gaúcha de energia - teve reconhecida na sentença a existência de débitos de usuários que foram autores de ações judiciais que questionavam exatamente a validade desses débitos. Frise-se, contudo, também ter sido encontrada a posição contrária nesta Corte. ${ }^{427}$

Aceitando-se tal utilização do processo, o mesmo instrumento poderá ser utilizado para efetivar a tutela prometida pelo direito material, de modo que o processo estaria cumprido indubitavelmente sua finalidade. Não se defende a execução indiscriminada da sentença declaratória pelo autor ou réu, até porque que nem mesmo a sentença condenatória tem esta aptidão. Porém, contendo a sentença declaratória os pressupostos para dar início à execução, não existem óbices à adesão a este entendimento.

\subsection{Ação declaratória negativa: procedência e improcedência}

\footnotetext{
${ }^{425}$ Relator Ministro Benedito Gonçalves, DJ 29/09/2010.

${ }^{426}$ O julgado assim conclui: "Destarte, observados os princípios da celeridade e economia processual, e considerando que o título exequendo reconheceu a existência da relação obrigacional entre as partes, adequado que a concessionária exija, nesses mesmos autos, a satisfação de seu crédito."

${ }^{427}$ Cite-se o Agravo de Instrumento 70044737658, Relatora Desembargadora Denise Oliveira Cezar, 22 ${ }^{\mathrm{a}}$ Câmara Cível, Julgamento em 27/10/2011, disponível em https://www1.tjrs.jus.br/site_php/consulta/consulta_processo.php?nome_comarca=Tribunal+de+Justi\%E7a\& versao $=\&$ versao_fonetica $=1 \&$ tipo $=1 \& i d \_c o m a r c a=700 \&$ num_processo_mask $=70044737658 \&$ num_process $\mathrm{o}=70044737658 \&$ codEmenta $=4425340 \&$ temIntTeor $=$ true
} 
Questão instigante é a relativa à propositura de ação que pede a declaração de inexistência de determinada relação jurídica. É comum, por exemplo, a ação declaratória negativa fiscal. A doutrina tem ressaltado que, ante os termos genéricos da lei, não há como afastar-se o cabimento de tal ação no campo do direito tributário. João Batista Lopes, contudo, sustenta que a ação declaratória negativa de débito fiscal não se confunde com a ação anulatória de débito fiscal, que é constitutiva e não declaratória, sendo o critério distintivo o lançamento do crédito tributário. ${ }^{428}$

Alguns autores, para responder a questão, fazem uma analogia com o preceito da ação direta de inconstitucionalidade - ADIN e da ação declaratória de constitucionalidade ADC, que têm caráter dúplice. Isso, porque quando o Supremo Tribunal Federal julga improcedente a ADIN, declara que a lei ou ato normativo federal ou estadual é constitucional. Quando julga improcedente a ADC, declara que a lei ou ato normativo federal é inconstitucional. Neste sentido, a ação declaratória negativa também teria essa natureza dúplice conforme o resultado.

Já outra parte da doutrina não corrobora com essa posição, sustentando que se a ação é julgada improcedente é porque, com relação àquela causa de pedir específica trazida pelo autor não é possível afirmar a existência da relação jurídica, o que não quer dizer, necessariamente, que não exista outra possível causa de pedir que leve à procedência do pedido, sem que com isso haja ofensa à coisa julgada, uma vez que os elementos identificadores da demanda, são partes, causa de pedir e pedido.

Eduardo Talamini é um dos autores que nega a possibilidade da sentença de improcedência gerar título ao réu, ao sustentar que, na verdade, a sentença que rejeita o pedido de declaração da inexistência de um direito não reconhece a existência desse direito, mas apenas nega a possibilidade de declarar sua inexistência por aquele fundamento que foi ali apresentado como causa de pedir. A sentença de rejeição da

\footnotetext{
${ }^{428}$ LOPES, João Batista. Ação declaratória, cit., p. 88. A afirmação é feita com base na doutrina de Arruda Alvim. Para João Batista Lopes, na ação declaratória negativa, visa o autor a obter declaração judicial com força de coisa julgada, para garantir-se futuramente contra possível procedimento judicial de cobrança (ou, segundo a doutrina dominante, em formulação pelo autor recusada, desfazer a incerteza jurídica acerca da existência ou inexistência de uma relação jurídica). Já na ação anulatória de débito fiscal não vai ele a juízo pleitear mero acertamento da relação jurídica, mas procurar desconstituir ato jurídico (lançamento) coberto por presunção juris tantum de legitimidade e legalidade (p. 88).
} 
demanda declaratória negativa, para o citado autor, não tem eficácia declaratória positiva, mas negativa, como todo e qualquer pronunciamento de improcedência. ${ }^{429}$

A esse respeito, é necessário distinguir da situação do art. 474 do Código de Processo Civil, que complementa e esclarece a norma da eficácia preclusiva da coisa julgada material do art. 471, ao incluir entre os pontos cujo reexame se proíbe todas as alegações e defesas que a parte poderia opor assim ao acolhimento como à rejeição do pedido. $\mathrm{O}$ intuito do referido dispositivo é impedir não só que o vencido volte à discussão de pontos já discutidos e resolvidos na motivação da sentença, como também que ele venha a suscitar pontos novos, não alegados nem apreciados, mas que sejam capazes de alterar a conclusão contida no decisório. Não se trata, contudo, na opinião de Dinamarco, de causas de pedir omitidas. ${ }^{430}$

Por outro lado, tem crescido na doutrina o entendimento de que o autor, ao levar a juízo sua pretensão, deve, desde já, trazer todas as causas de pedir possíveis, de forma a evitar que, uma vez julgado improcedente o pedido, possa continuar provocando o Judiciário, cada vez com uma nova causa de pedir, evitando-se a concretização do mais nobre dos escopos do processo que é a pacificação social. ${ }^{431}$

Na realidade, tendo o réu obtido tutela jurisdicional em face da pretensão do autor de natureza declaratória negativa e havendo norma jurídica individual a definir a relação jurídica, entendemos que é possível o início da execução pelo réu. Pela natureza dúplice da ação declaratória negativa, poderia o réu figurar como autor no sentido de mover uma demanda para obter a declaração de existência da relação.

Esta posição se pauta, sobretudo, na economia processual e no respeito à decisão judicial anteriormente prolatada, pois, dessa maneira, evita-se um desperdício de atividade judicial para se chegar na mesma conclusão, sob a proteção da coisa julgada.

\footnotetext{
429 TALAMINI, Eduardo. Sentença que reconhece obrigação como título executivo (CPC, art. 475-N, IAcrescido pela Lei 11.232/2005). Revista Jurídica. n. 344, São Paulo: Fonte do Direito, 2006, p. 35.

${ }^{430}$ DINAMARCO, Cândido Rangel. Instituições..., vol. III, cit., p. 331/332.

${ }^{431}$ Veja a esse respeito o estudo realizado no item 1.2.4, acerca da extensão da eficácia preclusiva da coisa julgada.
} 
E tal tese pode ser defendida independente da extensão que se queira atribuir à eficácia preclusiva da coisa julgada, do art. 474 do CPC. Ainda que se admita novas ações, com o mesmo pedido, mas com outras causas de pedir, o título executivo estaria formado e teria o executado que alegar tal nova causa de pedir na impugnação, nos termos do art. 475-L, ou por outro meio admissível de defesa. ${ }^{432}$

Neste sentido, o Tribunal de Justiça de São Paulo, ao julgar o Agravo de Instrumento $\mathrm{n}^{\mathrm{o}}$ 0134838-94.2011 ${ }^{433}$, reconheceu a possibilidade de sentença que julgou improcedente ação declaratória negativa ser utilizada como título executivo em favor do réu. No caso concreto, tratou-se de ação declaratória com o fim de ver "declarada a nulidade das duplicatas ou a inexistência dos débitos na forma como foram lançados, ou ainda, sejam elas declaradas inexigíveis, inexequíveis e ilíquidas, para todos os fins $e$ efeitos", tendo a sentença julgado improcedente a aludida ação, reconhecendo que "nada há de errado com os títulos".

Diante disso, o relator Desembargador Coutinho de Arruda considerou inegável que, na espécie, com a improcedência da ação declaratória, restou reconhecida a obrigação do agravado em pagar a quantia expressa nos títulos questionados, sendo inconteste que o juízo de certeza expresso no decisório foi resultado de ampla análise da relação jurídica que deu origem aos títulos, bem como da existência dos atributos inerentes às cártulas, tais como, certeza, exigibilidade e liquidez: “À evidência, a situação dos autos subsume-se ao disposto no art. 475-N, I, da lei de rito, dando-se ensejo ao cumprimento do título executivo judicial que reconheceu a obrigação de pagar quantia." ${ }^{434}$

O mesmo TJSP também preconizou este entendimento no Agravo de Instrumento $\mathrm{n}^{\mathrm{o}}$ 0117962-64.2011.8.26.0000 435 , interposto em a ação declaratória que foi julgada

\footnotetext{
${ }^{432}$ A esse respeito, v. item 2.7.

${ }^{433}$ Relator Desembargador Coutinho de Arruda, 16 Câmara de Direito Privado, Julgamento em 25/10/2011, disponível em https://esaj.tjsp.jus.br/cjsg/getArquivo.do?cdAcordao=5512394\&vlCaptcha=akyrd

${ }^{434}$ Prossegue o juiz: "Indubitável que vedar à agravante o direito de dar prosseguimento ao cumprimento da sentença proferida no bojo da ação declaratória, seria impor-lhe a utilização da ação de execução de título extrajudicial, ensejando o manejo de embargos versando sobre as matérias já decididas nos presentes autos. Certamente, tal situação, de forma alguma, se coaduna ao princípio da efetividade e celeridade processual, bem como à proteção à coisa julgada, consagrados na Constituição Federal."

435 Relator Desembargador Ademir Benedito, $21^{\text {a }}$ Câmara de Direito Privado, Julgamento em 21/09/2011, disponível em https://esaj.tjsp.jus.br/cjsg/getArquivo.do?cdAcordao=5442979\&vlCaptcha=arpyz
} 
improcedente, reconhecendo a exigibilidade das duplicatas objeto de litígio e tornando possível a sua execução, pelo réu, nos mesmos autos. ${ }^{436}$

\subsection{Sentenças declaratórias arbitral e estrangeira}

É possível que sentença arbitral declaratória reconheça a existência de obrigação. A questão que surge é se essa sentença, assim como a sentença arbitral condenatória, pode ser levada para execução no Poder Judiciário.

$\mathrm{O}$ art. 31 da Lei Federal no 9.307/1996 - a lei da arbitragem - prevê que a sentença arbitral produz, entre as partes e seus sucessores, os mesmo efeitos da sentença proferida pelos órgãos do Poder Judiciário e, sendo condenatória, constitui título executivo. A equiparação entre a sentença estatal e a arbitral faz com que a segunda produza os mesmo efeitos da primeira. Por consequência, além da extinção da relação jurídica processual e da decisão da causa - declaração, condenação ou constituição -, a decisão de mérito faz coisa julgada às partes entre as quais é dada, e não beneficiará ou prejudicará terceiro. ${ }^{437}$

Inicialmente, é necessário considerar o contexto da elaboração da lei de arbitragem, que foi aprovada pelo Congresso Nacional e sancionada em 1996. A redação do art. 584, I do CPC, como já discorrido inúmeras vezes neste estudo, era pela previsão expressa da sentença condenatória como título executivo judicial. Referido dispositivo foi revogado dando lugar à previsão do art. 475-N, inciso I.

Dessa forma, pode-se imaginar que, com a alteração do sistema processual em 2005 - que passou a vigorar em 2006 - o artigo 31 da lei da arbitragem passou a admitir igualmente como título executivo a sentença declaratória arbitral. No mesmo sentido, o art. 475-N, inciso IV, prevê como título executivo a sentença arbitral, sem menção expressa a sentença condenatória arbitral, como fazia entender a redação do art. 31 da lei de arbitragem antes da referida alteração.

\footnotetext{
${ }^{436}$ Mesmo que se entenda, conforme nota de João Batista Lopes acima, que os exemplos citados não tratam de ações declaratórias negativas mas sim constitutivas, ainda assim são cabíveis no estudo, pois seria igualmente possível alegar que outra causa de pedir tornaria as duplicadas inválidas.

${ }^{43}$ CARMONA, Carlos Alberto. Arbitragem e processo, cit., p. 314.
} 
Diante do até então asseverado sobre a eficácia executiva das sentenças declaratórias, é possível fazer uma interpretação sistemática, no sentido de conferir eficácia executiva à sentença arbitral declaratória, que reconheça a existência de obrigação de fazer, não fazer, entregar coisa ou pagar quantia.

Tal posição é defendida por Rafael Francisco Alves, inicialmente porque o próprio artigo 31 da lei dispõe que a sentença arbitral produz os mesmos efeitos da sentença judicial e, se idênticos, não haveria como deixar de reconhecer o efeito da executividade para a parcela das sentenças arbitrais declaratórias, que reconheçam a existência das obrigações mencionadas no art. 475-N, I. ${ }^{438}$

Assim, para que a eficácia executiva da sentença arbitral seja plena é imprescindível a sua liquidez, de forma que devem os árbitros, sempre que possível, determinar o quantum debeatur, de modo a evitar o processo judicial de liquidação.

De outra parte, cumpre analisar a sentença declaratória estrangeira como título executivo judicial. Como já foi sucintamente analisado acima ${ }^{439}$, a sentença estrangeira homologada pelo Superior Tribunal de Justiça é título executivo judicial, nos termos do inciso VI do art. 475-N do CPC. Na realidade, será título executivo judicial a homologação da sentença pelo STJ, isto é, o exequatur, e não a própria sentença estrangeira. A dúvida que se coloca é se sentença declaratória estrangeira que reconheça existência de obrigação poderá ser título executivo judicial.

Os arts. 483 e 484 do Código de Processo Civil preveem a homologação da sentença estrangeira e fazem referência ao Supremo Tribunal Federal, o que não está mais em sintonia com a Constituição Federal após a Emenda Constitucional 45 de 2004, que passou ao Superior Tribunal de Justiça competência para tanto (art. 105, I, $i$ da CF/88).

\footnotetext{
${ }^{438}$ ALVES, Rafael Francisco. A sentença arbitral como título executivo judicial: algumas observações a respeito do artigo 475-N do Código de Processo Civil. In COSTA, Suzana Henriques da (coord.), A Nova Execução Civil - Lei 11.232/05, São Paulo: Quartier Latin, 2006, p. 282/283. O autor, ao interpretar a nova sistemática executiva do Código, afirma que para a sentença arbitral, caberá sempre a execução da sentença pelo Livro I, nos termos do art. 475-J e seguintes, independentemente do tipo de obrigação que reconheça (fazer, não fazer, entregar coisa ou pagar quantia). O que, contudo, não chega a impedir a utilização das medidas previstas nos artigos 461 e 461-A, de cumprimento da sentença (p. 286/287).

${ }^{439}$ V. item 2.4.1.
} 
A Resolução $n^{\circ} 9$ de 2005 do STJ regulamenta a homologação da sentença estrangeira naquela corte, prevendo que a sentença estrangeira não terá eficácia no Brasil sem a prévia homologação. Frise-se que não há exigência que tal sentença seja condenatória. $\mathrm{O}$ art. 12 da referida resolução dispõe que a sentença estrangeira homologada será executada por carta de sentença, no juízo federal competente.

Dessa forma, igualmente interpretado o dispositivo de forma sistemática, parece possível afirmar que a sentença estrangeira, ainda que declaratória, caso reconheça a existência de obrigação, poderá ser executada pelo interessado no Brasil. 


\section{CONCLUSÃO}

A Lei Federal 11.232 de 22 de dezembro de 2005 - assim como tantas outras que reformaram o Código de Processo Civil nas últimas duas décadas - introduziu profundas alterações no sistema executivo do Código, transformando a execução da sentença em fase do processo, acabando com a necessidade de processo executivo de título judicial de obrigação de pagar quantia - processo civil sincrético.

Referido diploma legal também modificou conceitos e previsões do Código para readequá-lo à nova realidade, na tentativa de dar coesão ao sistema processual já tão modificado pelo legislador. Dentre as alterações, destaca-se a previsão do rol de títulos executivos judiciais, no art. 475-N, especialmente no inciso I, que prevê como tal a sentença que reconheça a existência de obrigação de fazer, não fazer, entregar coisa ou pagar quantia, em substituição à previsão do revogado art. 584, inciso I do Código, que expressamente reservava tal qualidade à sentença condenatória proferida no processo civil.

Nesse contexto, ganha relevância a discussão da tese de que a sentença declaratória, além da condenatória, pode possuir eficácia executiva. E a atribuição de eficácia executiva à sentença declaratória repercute de forma considerável no direito processual civil. No presente estudo, pretendeu-se demonstrar que é possível cientificamente reconhecer a tese, através da análise da doutrina e da jurisprudência, com enfoque na tão almejada efetividade do processo, sem deixar de lado a necessária técnica processual.

Dessa forma, viu-se que a tutela jurisdicional é o conjunto de medidas estabelecidas pelo legislador processual a fim de conferir efetividade a uma situação da vida amparada pelo direito substancial. Ter direito fundamental à tutela jurisdicional efetiva é ter direito às técnicas processuais idôneas à obtenção da tutela prometida pelo direito material, devendo a tutela jurisdicional, portanto, ser considerada como a análise do fenômeno processual do ângulo de quem tem razão.

Ainda que se reconhecendo a atipicidade da tutela jurisdicional, no sentido de que, ao menos em princípio, não há um rol previamente estabelecido de provimentos aptos à 
proteção de direitos e interesses materiais, recomenda-se que se busque uma tipologia dessa mesma tutela. Dentro do tipo das ações de conhecimento, há classicamente a tipologia das tutelas meramente declaratória, constitutiva e condenatória, ao lado das quais parcela da doutrina ainda cita as tutelas mandamental e executiva, contrapondo-se, assim, as chamadas teorias ternária e quinária da ação.

Neste sentido, frisou-se a distinção entre tutela jurisdicional e sentença, posto que a sentença é apenas uma técnica processual, elaborada pelo legislador, para propiciar as tutelas prometidas pela Constituição e pelo direito material, não consistindo a tutela jurisdicional na prolação da sentença em si mesma, mas pela sentença e pelos efeitos que ela projeta na vida das pessoas.

Estudou-se profundamente, assim, dentro desse contexto de tutela jurisdicional estatal, a sentença, seus efeitos, a distinção entre as diferentes espécies de sentenças, conforme teorias ternária e quinária mencionadas, a coisa julgada e seus limites, verificando-se que a distinção das tutelas, sob o ponto de vista executivo, deixou de ser relevante, na medida em que a sentença civil que reconheça a existência de obrigação de fazer, não fazer, entregar coisa ou pagar quantia, independentemente da classe a qual pertença, será título executivo judicial, nos termos do art. 475-N, I.

Da mesma forma, viu-se as operações que, em decorrência da natureza do provimento reclamado e obtido pelo vitorioso, destinam-se a entregar-lhe o bem da vida, realizando-se no mundo real aquilo que restou reconhecido no processo. Assim, foram analisadas a execução e o cumprimento da sentença, conforme sistema executivo implementado no CPC pela Lei 11.232/05, que extinguiu o processo de execução de sentença e a previu como fase do processo civil, promovendo maior celeridade ao procedimento.

A esse respeito, estudou-se também o rol dos títulos executivos judiciais do art. 475-N, em especial as decisões judiciais - sentenças, acórdãos e decisões interlocutórias -, no que consistem as obrigações de fazer, não fazer, entregar coisa e pagar quantia, a execução provisória e as defesas do executado, denotando a execução da sentença civil. 
Finalmente, viu-se a carga executiva da sentença civil, no sentido de que a sentença passível de execução é aquela que reconheça a existência de obrigação de fazer, não fazer, entregar coisa ou pagar quantia, podendo ser condenatória, constitutiva ou declaratória. Frise-se que importante doutrina refuta a tese de atribuição de eficácia executiva à sentença declaratória, fundamentalmente em razão de inconstitucionalidade formal do dispositivo, que não teria retornado para aprovação da Câmara dos Deputados, e por contrariar tradicional classificação das tutelas no direito brasileiro.

Neste sentido, parece-nos que o processo legislativo considerou expressamente a tese do processualista e ministro do STJ Teori Albino Zavascki, que já defendia com o texto original do Código de 1973 em artigos doutrinários e em julgados a existência de eficácia executiva da sentença declaratória, por considerar desnecessária uma nova demanda apenas para conferir a sanção estatal ao devedor, além de reconhecer que o parágrafo único do art. $4^{\circ}$ do Código permite a ação declaratória ainda que já tenha ocorrido a violação do direito. Assim, não inovando na ordem jurídica, a mens legislatoris foi no sentido de dar à redação ao art. 475-N, I, sentido que já tinha antes do advento da lei.

Além do mencionado autor, viu-se que outros doutrinadores de renome, como Humberto Theodoro Jr, Athos Gusmão Carneiro, Marcelo Abelha, Paulo Lucon, entre outros, manifestaram-se favoravelmente à possibilidade da sentença declaratória ser título executivo, atentando contra o bom senso e a economia processual a imposição de uma nova cognição para que sentença futura imponha apenas a sanção executiva. Portanto, a interpretação está em consonância com o ideal de instrumentalidade do processo, na busca do processo de civil de resultados.

A jurisprudência dos tribunais também se manifestou sobre o assunto, havendo diversos julgados aplicando a eficácia executiva das sentenças declaratórias na solução dos conflitos que são levados diariamente ao Poder Judiciário. O STJ em várias ocasiões consignou entendimento pela possibilidade, em julgados do já citado Ministro Teori Albino Zavascki, e também do Ministro Castro Meira, Ministro Mauro Campbell Marques, Ministra Eliana Calmon, Ministro Herman Benjamin, Ministro Hamilton Carvalhido e Desembargador Convocado do TJ/SP Celso Limongi, em alguns casos até em decisão 
monocrática, nos termos do art. 557 do CPC. No mesmo sentido, há julgados do TJSP, TJRJ, TJMG, TJRS, TJPR e TJES, TRF/1 ${ }^{\mathrm{a}}, \mathrm{TRF} / 2^{\mathrm{a}}$ e TRF/3 ${ }^{\mathrm{a}}$.

De outra parte, viu-se a possibilidade de execução da sentença declaratória tanto pelo autor como pelo réu, pois contendo a sentença reconhecimento de obrigação em seu favor, não existem óbices ao prosseguimento, havendo igualmente pronunciamento favorável da doutrina e jurisprudência. Por outro lado, verificou-se que a sentença que julga improcedente ação declaratória negativa também pode gerar título executivo em favor do réu, posto que, em razão do caráter dúplice da ação, acaba por reconhecer a existência da relação que se queria negar. Tendo o réu obtido tutela jurisdicional em face da pretensão do autor e havendo norma jurídica individual a definir a relação jurídica, passa a ser possível o início da execução pelo réu.

Por fim, ressaltou-se a possibilidade de a sentença declaratória arbitral, numa interpretação sistemática das normas processuais, também ser considerada título executivo judicial. A mesma foi a conclusão com relação à sentença declaratória estrangeira.

Ressalte-se que a previsão do art. 475-N, inciso I está reproduzida no projeto de lei do novo Código de Processo Civil em trâmite no Congresso Nacional. O Substitutivo ao Projeto de Lei 166/2010 foi aprovado no Senado Federal em dezembro de 2010 e permanece sob análise de uma comissão especial da Câmara dos Deputados, sob o $\mathrm{n}^{\circ}$ $8.046 / 2010$.

$\mathrm{O}$ art. 502, inciso I do projeto de lei prevê que além da sentença condenatória, serão também objeto de cumprimento, de acordo com os artigos previstos no Título do Cumprimento da Sentença do Código, as sentenças proferidas no processo civil que reconheçam a exigibilidade de obrigação de pagar quantia, de fazer, de não fazer ou de entregar coisa. Dessa forma, a importância do presente estudo permanecerá com o advento do novo Código. 


\section{REFERÊNCIAS BIBLIOGRÁFICAS}

ALVES, Rafael Francisco. A sentença arbitral como título executivo judicial: algumas observações a respeito do artigo 475-N do Código de Processo Civil. In COSTA, Suzana Henriques da (coord.), A Nova Execução Civil - Lei 11.232/05, São Paulo: Quartier Latin, 2006, pp. 271-290

ASSIS, Araken de. Cumprimento da Sentença. $3^{\text {a }}$ Ed., Rio de Janeiro: Forense, 2010 Sentença condenatória como título executivo. In WAMBIER, Teresa Arruda Alvim (coord). Aspectos polêmicos da nova execução 3: de títulos judiciais, Lei 11.232/2005, São Paulo: Revista dos Tribunais, 2006, pp. 11-22

AURELLI, Arlete Inês. As principais alterações no regime da execução por quantia certa contra devedor solvente referente a título judicial, trazidas pela Lei 11.232, de 22.12.2005. In WAMBIER, Teresa Arruda Alvim (coord). Aspectos polêmicos da nova execução 3: de títulos judiciais, Lei 11.232/2005, São Paulo: Revista dos Tribunais, 2006, pp. 23-43.

BARBOSA MOREIRA, José Carlos. Comentários ao Código de Processo Civil, vol. V, $12^{\mathrm{a}}$ ed., Rio de Janeiro: Forense, 2005

Os novos rumos do processo civil brasileiro, In RePro, vol. 78,

pp. $133 / 145$

BEDAQUE, José Roberto dos Santos. Direito e Processo - influência do direito material sobre o processo. $5^{\mathrm{a}}$ ed, São Paulo: Malheiros, 2009

Efetividade do Processo e Técnica Processual. São Paulo:

Malheiros, 2006

. Poderes Instrutórios do Juiz, $3^{\mathrm{a}}$ ed, São Paulo: RT, 2001

BERMUDES, Sérgio. Código de Processo Civil: mudança inútil. Artigo publicado no Jornal O Globo de 21/12/2010

BOTELHO DE MESQUITA, José Ignacio. A coisa julgada. $1^{\mathrm{a}}$ Ed., Rio de Janeiro: Forense, 2004

BUENO, Cassio Scarpinella. Curso Sistematizado de Direito Processual Civil: Tutela Jurisdicional Executiva, vol. 3. São Paulo: Saraiva, 2008 
A nova etapa da reforma do Código de Processo Civil: comentários sistemáticos às Leis n. 11.187, de 19-10-2005, e 11.232, de 22-12-2005, vol. 1, $2^{\text {a }}$ ed. rev., atual. e ampl., São Paulo: Saraiva, 2006, p. 160/166.

CÂMARA, Alexandre Freitas. A Nova Execução de Sentença, $6^{\mathrm{a}}$ ed., Rio de Janeiro: Lumen Juris, 2009

CARMONA, Carlos Alberto. Arbitragem e processo: um comentário à Lei $n^{\circ}$ 9.307/96. $2^{\mathrm{a}}$ ed, São Paulo: Atlas, 2006

Ensaio sobre a sentença arbitral parcial. In JAYME, Fenando Gonzaga; FARIA, Juliana Cordeiro de; LAUAR, Maira Terra (coord). Processo Civil: novas tendências: estudos em homenagem ao Professor Humberto Theodoro Junior. Belo Horizonte: Del Rey, 2008, pp. 115-135

CARNEIRO, Athos Gusmão. Do 'cumprimento da sentença', conforme a Lei 11.232/2005. Parcial retorno ao medievalismo? Por que não?. In WAMBIER, Teresa Arruda Alvim (coord). Aspectos polêmicos da nova execução 3: de títulos judiciais, Lei 11.232/2005, São Paulo: Revista dos Tribunais, 2006, pp. 51-91

CARNELUTTI, Francesco. Studi di Diritto Processuale, volume terzo, Padova, Cedam Casa Editrice Dott. Antonio Milani, 1939

CARREIRA ALVIM, José Eduardo. Execução de sentenças penal, arbitral e estrangeira (art. 475-N, parágrafo único, do CPC) - Processo de execução ou execução sincretizada (cumprimento)?. In WAMBIER, Teresa Arruda Alvim (coord). Aspectos polêmicos da nova execução 3: de títulos judiciais, Lei 11.232/2005, São Paulo: Revista dos Tribunais, 2006, pp. 330-338

CHIOVENDA, Giuseppe. Instituciones de Derecho Procesal Civil. trad. E. Gomez Orbaneja, vol. 3, Madrid, Editorial Revista de Derecho Privado, 1954

DIDIER JR, Fredie. Extensão da eficácia preclusiva da coisa julgada. Art. 474 do CPC, o art. 495 do NCPC e o art. 98, $\S 4^{o}$, da Lei 12.529/2011. Editorial 132 de 13/12/2011, disponível em <http://www.frediedidier.com.br/main/noticias/impressao.jsp?CId=477>, acesso em $7 / 1 / 2012$. 
DIDIER JR., Fredie; CUNHA, Leonardo Carneiro da; BRAGA, Paula Sarno; OLIVEIRA, Rafael. Curso de Direito Processual Civil - Execução. Vol. 5, $3^{\text {a }}$ ed., Salvador: JusPodivm, 2011

DINAMARCO, Cândido Rangel. A Instrumentalidade do Processo, $12^{\mathrm{a}}$ ed., São Paulo: Malheiros, 2005

Instituições de Direito Processual Civil, vol. I, II e III, $5^{\text {a }}$ Ed., São Paulo: Malheiros, 2005 Instituições de Direito Processual Civil, vol. III, 6ª Ed., São Paulo: Malheiros, 2009 Instituições de Direito Processual Civil, vol. IV, $3^{\mathrm{a}}$ Ed., São Paulo: Malheiros, 2009 Nova Era do Processo Civil, $2^{\mathrm{a}}$ ed., São Paulo: Malheiros, 2007

GRINOVER, Ada Pellegrini. Eficácia e autoridade da sentença: a teoria de Liebman no Código de Defesa do Consumidor e no Código Modelo de Processos Coletivos para Ibero-América. No prelo, p. 203.

LEÃO, José Francisco Lopes de Miranda. Sentença Declaratória - eficácia quanto a terceiros e eficiência da Justiça. Dissertação de mestrado apresentada na Universidade de São Paulo, 1998

LIEBMAN, Enrico Tullio. Eficácia e autoridade da sentença e outros escritos sobre a coisa julgada. Trad. Alfredo Buzaid e Benvindo Aires, Rio de Janeiro: Revista Forense, 1945

LOPES, João Batista. Ação Declaratória. $5^{\text {a }}$ ed., São Paulo: Ed. Revista dos Tribunais, 2002

LUCON, Paulo Henrique do Santos. Coisa julgada, efeitos da sentença, coisa julgada inconstitucional e embargos à execução do art. 741, par. ún.. Revista do Advogado (São Paulo), São Paulo, v. 84, 2005, pp. 145-167

MARCATO, Antonio Carlos. A imparcialidade do juiz e a validade do processo, In Revista Direito Mackenzie, São Paulo, vol. 1, n. 2, jul/dez 2000, p. 67 (coord). Código de Processo Civil Interpretado. $3^{\mathrm{a}}$ ed, São 
MARINONI, Luiz Guilherme; ARENHART, Sérgio Cruz. Curso de processo civil, volume

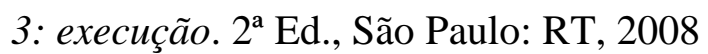

MEDINA, José Miguel Garcia; WAMBIER, Luiz Rodrigues; WAMBIER, Teresa Arruda Alvim. Sobre a impugnação à execução de título judicial (arts. 475-L e 475-M do CPC). In WAMBIER, Teresa Arruda Alvim (coord). Aspectos polêmicos da nova execução 3: de títulos judiciais, Lei 11.232/2005, São Paulo: Revista dos Tribunais, 2006, pp. 396-415.

MIRANDA, Pontes de. Tratado das Ações. São Paulo: RT, 1970, t. I.

NALINI, José Renato. O juiz e o acesso à justiça. $2^{\mathrm{a}}$ ed., São Paulo: RT, 2000

NERY JUNIOR, Nelson; NERY, Rosa Maria de Andrade. Código de processo civil comentado e legislação extravagante. $11^{\mathrm{a}}$ ed. rev. ampl. e atual. até 17.2.2010, São Paulo: Editora Revista dos Tribunais, 2010

NEVES, Celso. Estrutura fundamento do processo civil: tutela jurídica processual, ação, processo e procedimento. Rio de Janeiro: Forense, 1997

PALHARES, Cinara. A sentença cível como título executivo judicial - Considerações sobre o art. 475-N, I, do CPC. In BUENO, Cassio Scarpinella; WAMBIER, Teresa Arruda Alvim (coord). Aspectos polêmicos da nova Execução, v. 4. São Paulo: Revista do Tribunais, 2008, pp. 80-101

PARÁ FILHO, Tomás. A Sentença Constitutiva. Dissertação de concurso à cadeira de direito judiciário civil da Faculdade de Direito da Universidade de São Paulo, São Paulo, 1973

PEREIRA, Rafael Caselli. O dogma da condenatoriedade - a sentença declaratória como título executivo judicial. Disponível na página da Academia Brasileira de Direito Processual Civil (www.abdpc.org.br), acesso em 6/1/2012

PINHO, Frederico Andrade de Macedo. Sentença meramente declaratória, título executivo e execução pelo réu. Jus Navigandi, Teresina, ano 14, n. 2273, 21 set. 2009. Disponível em: 〈http://jus.com.br/revista/texto/13531〉. Acesso em: 4 dez. 2011.

PUOLI, José Carlos Baptista. Os poderes do juiz e as reformas do processo civil, $1^{\mathrm{a}}$ ed., São Paulo: Ed. Juarez de Oliveira, 2002

ROCCO, Alfredo, La sentenza civile, Studi, Milano, Giuffrè, 1962. 
RODRIGUES, Marcelo Abelha. Manual de execução civil. $4^{\mathrm{a}}$ ed., rev. e atual. Rio de Janeiro: Forense Universitária, 2009

SANTOS, Moacyr Amaral. Primeiras Linhas de Direito Processual Civil. Vol. 3, 23 ${ }^{\text {a }}$ Ed., São Paulo: Saraiva, 2009

SHIMURA, Sérgio. A execução da sentença na reforma de 2005. In WAMBIER, Teresa Arruda Alvim (coord). Aspectos polêmicos da nova execução 3: de títulos judiciais, Lei 11.232/2005, São Paulo: Revista dos Tribunais, 2006, pp. 546-586

TALAMINI, Eduardo. Sentença que reconhece obrigação como título executivo (CPC, art. 475-N, I - Acrescido pela Lei 11.232/2005). Revista Jurídica. n. 344, São Paulo: Fonte do Direito, 2006

TEIXEIRA, Salvio de Figueiredo. A efetividade do processo e a reforma processual, In RePro, vol. 78, p. 88

THEODORO JUNIOR, Humberto. A sentença declaratória e sua possível força executiva. Tex Pro, 5 abril 2011, disponível em <http://www.tex.pro.br/tex/listagem-deartigos/324-artigos-abr-2011/7957-a-sentenca-declaratoria-e-sua-possivel-forcaexecutiva>. Acesso em 4 dez 2011. As vias de execução do Código de Processo Civil brasileiro reformado. In WAMBIER, Teresa Arruda Alvim (coord). Aspectos polêmicos da nova execução 3: de títulos judiciais, Lei 11.232/2005, São Paulo: Revista dos Tribunais, 2006, pp. 284-329 - Curso de Direito Processual Civil - Processo de Execução e Cumprimento da Sentença, Processo Cautelar e Tutela de Urgência. $43^{\mathrm{a}}$ Ed., Rio de Janeiro: Forense, 2008 . Processo de Execução e Cumprimento da Sentença, 26 $6^{\mathrm{a}}$ ed., São Paulo, Liv. e Ed. Universitária de Direito, 2009

VASCONCELOS, Ronaldo. Eficácia executiva das sentenças declaratórias no CPC (Lei n. 11.232/05), In COSTA, Suzana Henriques da (coord.), A Nova Execução Civil Lei 11.232/05, São Paulo: Quartier Latin, 2006

WAMBIER, Luiz Rodrigues. Sentença Civil: Liquidação e Cumprimento. $3^{\mathrm{a}}$ Ed. São Paulo: Revista dos Tribunais, 2006 
YARSHELL, Flavio Luiz. Tutela Jurisdicional e Tipicidade. Tese de Doutoramento na Universidade de São Paulo, 1997

ZAVASCKI, Teori Albino. Processo de execução: parte geral. $3^{\mathrm{a}}$ ed. rev., atual. e ampl. São Paulo: Editora Revista dos Tribunais, 2004 (Coleção estudos de direito de processos Enrico Tulio Liebman; 42)

Sentenças Declaratórias, Sentenças Condenatórias e Eficácia Executiva dos Julgados. In RePro 109, p. 45. 